\title{
FINAL
}

\section{Engineering Development of Coal-Fired High \\ Performance Power Systems \\ Phase II and III}

DE-AC22-95PC95144

Quarterly Progress Report

April 1 - June 30, 1998

\section{Prepared for}

Federal Energy Technology Center

Pittsburgh, Pennsylvania

\author{
United Technologies Research Center \\ 411 Silver Lane, East Hartford, Connecticut 06108
}


"This report was prepared as an account of work sponsored by an agency of the United States government. Neither the United States Government nor any agency thereof, nor any of their employees, makes any warranty, express or implied, or assumes any legal liability or responsibility for the accuracy, completeness, or usefulness of any information, apparatus, product, or process disclosed, or represents that its use would not infringe privately owned rights. Reference herein to any specific commercial product, process, or service by trade name, trademark, manufacturer, or otherwise does not necessarily constitute or imply its endorsement, recommendation, or favoring by the United States Government or any agency thereof. The views and opinions of authors expressed herein do not necessarily state or reflect those of the United States Government or any agency thereof." 


\begin{abstract}
This report presents work carried out under contract DE-AC22-95PC95144 "Engineering Development of Coal-Fired High Performance Systems Phase II and III." The goals of the program are to develop a coal-fired high performance power generation system (HIPPS) that is capable of:

$\diamond \quad$ thermal efficiency (HHV) $\geq 47 \%$

$\diamond \quad$ NOx, SOx, and particulates $\leq 10 \%$ NSPS

(New Source Performance Standard)

$\diamond \quad$ coal providing $\geq 65 \%$ of heat input

$\diamond \quad$ all solid wastes benign

$\diamond$ cost of electricity $\leq 90 \%$ of present plants

Phase I, which began in 1992, focused on the analysis of various configurations of indirectly fired cycles and on technical assessments of alternative plant subsystems and components, including performance requirements, developmental status, design options, complexity and reliability, and capital and operating costs. Phase I also included preliminary R\&D and the preparation of designs for HIPPS commercial plants approximately $300 \mathrm{MWe}$ in size. This phase, Phase II, involves the development and testing of plant subsystems, refinement and updating of the HIPPS commercial plant design, and the site selection and engineering design of a HIPPS prototype plant.
\end{abstract}

Work reported herein is from:

$\diamond \quad$ Task 2.1 HITAF Combustor;

$\diamond \quad$ Task 2.2 HITAF Air Heaters;

$\diamond \quad$ Task 6 HIPPS Commercial Plant Design Update 


\section{Table of Contents}

Abstract ........................................................................................................................... i

Table of Contents ..................................................................................................... iii

List of Exhibits ........................................................................................................ $\mathrm{v}$

Executive Summary ..............................................................................................................

Task 2.1 HITAF Combustor ...........................................................................................

Task 2.2 HITAF Air Heaters .........................................................................................

Task 6 HIPPS Commercial Plant Design Update................................................ xiii

Introduction ............................................................................................................................xiv

Task 2.1 HITAF Combustor ............................................................................... 2-1

Model Pilot Dilution/Convective Heater/SNCR .................................................. 2-1

Task 2.2 HITAF Air Heaters ...................................................................... 2.2-1

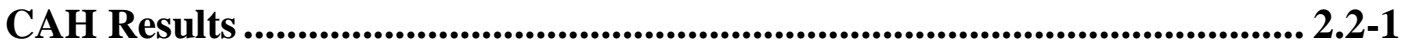

Raw Temperature Plots - April Test ……………………........................ 2.2.2

Heat Flux Plots - April, March, and May Tests............................................ 2.2. $2-3$

Large RAH Results ...................................................................................... 2.2.5

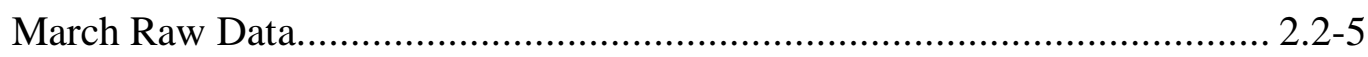

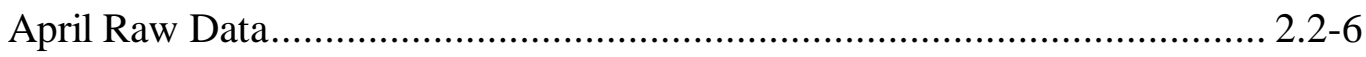

June Raw Data............................................................................... 2.2. 2 -

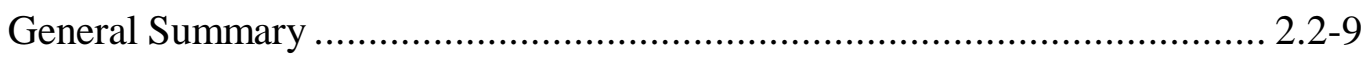

Small RAH Results...................................................................................... 2.2-10

April Summary Results …………….................................................. 2.2.11

June Summary Results ............................................................... 2.2.13

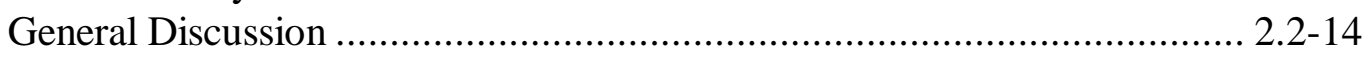

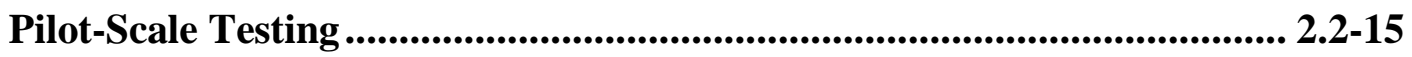

Pilot-Scale Slagging Furnace System..................................................... 2.2. 2-16

Pilot-Scale SFS Operation .............................................................. 2.2.2-30

Testing of the CAH Tube Bank .............................................................. 2.2.2-45

Testing of the LRAH Panel................................................................. 2.2-63

Testing of the SRAH Panel ................................................................... 2... 2.2-79

HITAF Air Heater Materials .............................................................. 2.2.2-90

Laboratory- and Bench-Scale Activities ................................................ 2.2-107

Task 6 HIPPS Commercial Plant Design Update ................................................... 6-1 


\section{List of Exhibits}

Exhibit 2.2-1 Flue Gas \& Air Temperatures $2.2-2$

Exhibit 2.2-2 Exit Air Temperatures 2.2-2

Exhibit 2.2-3 Inlet \& Shell Surface Temperatures $\quad 2.2-3$

Exhibit 2.2-4 Net Heat Flux - April Test 2.2-3

Exhibit 2.2-5 Net Heat Flux - March Test 2.2-4

Exhibit 2.2-6 Net Heat Flux - June Test 2.2-4

Exhibit 2.2-7 Air Temperatures \& Air Flow Rate 2.2-5

Exhibit 2.2-8 Tube Temperature \& Coal Feed Rate 2.2-5

Exhibit 2.2-9 Air Flow \& Pressure Drop 2.2-6

Exhibit 2.2-10 Air Temperatures \& Air Flow Rate 2.2-6

Exhibit 2.2-11 Tube Temperature \& Coal Feed Rate 2.2-7

Exhibit 2.2-12 Tube Temperature \& Coal Feed Rate (expanded) 2.2-7

Exhibit 2.2-13 Brick Centerline Temperatures (expanded) 2.2-7

Exhibit 2.2-14 Air Temperatures \& Air Flow Rate 2.2-8

Exhibit 2.2-15 Tube Temperature \& Coal Feed Rate 2.2-8

Exhibit 2.2-16 Average Temperature Increase 2.2-9

Exhibit 2.2-17 Comparison Between Design and Operation Conditions $2.2-10$

Exhibit 2.2-18 Brick Back Center Temperature 2.2-11

Exhibit 2.2-19 Sensor Temperature Comparison 2.2-11

Exhibit 2.2-20 Sensor Temperature Comparison (expanded) 2.2-12

Exhibit 2.2-21 Cooling Water Temperature Increase 2.2-12

Exhibit 2.2-22 Brick Back Center Temperature 2.2-13

Exhibit 2.2-23 Sensor Temperature Comparison 2.2-13

Exhibit 2.2-24 Cooling Water Temperature Increase 2.2-14

Exhibit 2.2-25 Back Surface Temperature Difference - April Test 2.2-15

Exhibit 2.2-26 Back Surface Temperature Difference - June Test 2.2-15

Exhibit 2.2-27 Combustion 2000 Slagging furnace and Support Systems $2.2-17$

Exhibit 2.2-28 Flow and Heat-Transfer Calculations for Combustion 2000 Slagging Furnace and Refractory Ducts Illinois No. 6 Bituminous 2.2-20

Exhibit 2.2-29 Refractory Properties

$2.2-23$

Exhibit 2.2-30 Photographs of the Installed SRAH Panel from the Exterior and Interior of the Furnace 2.2-26

Exhibit 2.2-31 Pressure, Temperature, and Flow Specifications for SFS Fans 2.2-29

Exhibit 2.2-32 Lignite Feed Rate versus Run Time for the April 1998 Test Period 2.2-31

Exhibit 2.2-33 Lignite Feed Rate versus Run Time for the June 1998 Test Period 2.2-31

Exhibit 2.2-34 Results of Coal and Coal Ash Analysis for Coal-Fired Slagging Furnace Tests 
Exhibit 2.2-35 Results of Lignite and Lignite Ash Analysis for Lignite-Fired Slagging Furnace Tests

Exhibit 2.2-36 Furnace and Slag Screen Temperatures versus Run Time for the April 1998 Test Period

Exhibit 2.2-37 Furnace and Slag Screen Temperatures versus Run Time for the June 1998 Test Period

Exhibit 2.2-38 Slagging Furnace Firing Rate versus Run Time for the April 1998 Test Period

Exhibit 2.2-39 Slagging Furnace Firing Rate versus Run Time for the June 1998 Test Period

Exhibit 2.2-40 Photograph of Slag Screen Tubes from April Test Period

Exhibit 2.2-41 Cooling Air Preheater Temperatures versus Run Time for the April Test Period

Exhibit 2.2-42 Cooling Air Preheater Temperatures versus Run Time for the June Test Period

Exhibit 2.2-43 Flue Gas Emissions for Lignite-Fired Slagging Furnace Tests

Exhibit 2.2-44 CAH Tube Surface and Flue Gas Temperatures versus Run Time for the April Test Period

Exhibit 2.2-45 CAH Cooling Air Temperatures versus Run Time for the April Test Period 2.2-47

Exhibit 2.2-46 CAH Cooling Air, LRAH Cooling Air, Quench Gas, and Glue Gas Flow Rates versus Run Time for the April Test Period

Exhibit 2.2-47 Thermocouple Locations in the CAH Tube Bank

Exhibit 2.2-48

Description of CAH Thermocouple Locations

Exhibit 2.2-49

CAH Heat Recovery versus Run Time for the April Test Period

Exhibit 2.2-50

Photograph of Ash Deposits on the CAH Tubes Following the April Test Period Firing Coal Creek-Falkirk Lignite

Exhibit 2.2-51 XRF Analysis Results for Selected Coal Creek Lignite, Slag, and Ash Samples Collected During and After the April Test Period (normalized, sulfur-free oxide wt $\%$ )

Exhibit 2.2-52 CAH Tube Surface an Flue Gas Temperatures versus Run Time for the June Test Period

Exhibit 2.2-53 CAH Cooling Air Temperatures versus Run Time for the June Test Period

Exhibit 2.2-54 CAH Cooling Air, LRAH Cooling Air, Quench Gas, and Flue Gas Flow Rates versus Run Time for the June Test Period

Exhibit 2.2-55 CAH Heat Recovery versus Run Time for the June Test Period

Exhibit 2.2-57 Photographs of Uncooled Stainless Steel Tubes Used in the CAH Tube Bank to Replace Damaged Ceramic Tubes

Exhibit 2.2-58 XRF Analysis Results for Selected Center Lignite, Slag, and Ash Samples Collected During and After the June Test Period (normalized, sulfur-free oxide wt\%) 
Exhibit 2.2-59 Photograph of the Modified CAH Tube Bank

2.2-63

Exhibit 2.2-60 Photograph of the LRAH and SRAH Panels Prior to the April Test Period 2.2-64

Exhibit 2.2-61 Illustration of Cracks Found in the Ceramic Tiles/Bricks of the

LRAH Panel after Testing in June 1998

$2.2-65$

Exhibit 2.2-62 LRAH Ceramic Tile Temperatures versus Run Time for the April

Test period

2.2-67

Exhibit 2.2-63

LRAH Tube Surface Temperatures versus Run Time for the April Test

2.2-68

Exhibit 2.2-64 LRAH Cooling Air Temperatures versus Run Time for the April

Test Period

Exhibit 2.2-65

Illustration of Thermocouple Locations in the LRAH Panel

2.2-70

Exhibit 2.2-66

Description of LRAH Panel Thermocouple Locations

2.2-71

Exhibit 2.2-67

LRAH Heat Recovery versus Run Time for the April Test Period

2.2-72

Exhibit 2.2-68

Photograph of LRAH and SRAH Panels inside of the Slagging Furnace

Following the April Test Period

$2.2-73$

Exhibit 2.2-69 Photograph of the LRAH Panel from Inside of the Furnace after the April Test Period

2.2-74

Exhibit 2.2-70 LRAH Ceramic Tile Temperatures versus Run Time for the June Test Period

Exhibit 2.2-71 LRAH Tube Surface Temperatures versus Run Time for the June Test Period

Exhibit 2.2-72 LRAH Cooling Air Temperatures versus Run Time for the June Test Period

Exhibit 2.2-73 LRAH Heat Recovery versus Run Time for the June Test Period

Exhibit 2.2-74 Photograph of the LRAH and SRAH Panels Inside of the Slagging Furnace Following the June Test Period

Exhibit 2.2-75 Photograph of the SRAH Panel Following Replacement of the Damaged Tiles/Bricks Prior to the June Test Period

Exhibit 2.2-76 Illustration of Cracks Found in the Ceramic Tiles/Bricks of the SRAH Panel after Testing in June 1998

Exhibit 2.2-77 SRAH Ceramic Tile Temperatures versus Run Time for the April Test Period

Exhibit 2.2-78

Illustration of Thermocouple Locations in the SRAH Panel

$2.2-84$

Exhibit 2.2-79

Description of SRAH Panel Thermocouple Locations

2.2-85

Exhibit 2.2-80

SRAH Heat Recovery versus Run Time for the April Test Period

2.2-86

Exhibit 2.2-81

Photograph of the SRAH Panel from Inside of the Furnace after the April Test Period

Exhibit 2.2-82 SRAH Ceramic Tile Temperatures versus Run Time for the June Test Period

Exhibit 2.2-83 SRAH Heat Recovery versus Run Time for the June Test Period

Exhibit 2.2-84 Flexural Strength and Modulus of Fusion Cast Refractories at Various Temperatures 
Exhibit 2.2-85 Effect of Temperature on Elastic Modulus of Monofrax L, Monofrax M, Monofrax K-3, and ACF-10 (experimental).

Exhibit 2.2-86 Effect of Temperature on 4-point Flexural Strength of Monofrax L, Monofrax M, Monofrax K-3, and ACF-10 (experimental). 2.2-93

Exhibit 2.2-87 Hot face [A] and Cool Face [B] of Monofrax M Large-RAH Top Tile

2.2-94

Exhibit 2.2-88 Vertical Cross-Section of Monofrax Top Tile Shown in Exhibit 2.2-87

2.2-95

Exhibit 2.2-89 Magnified views of Exhibit 2.2-88B

2.2-97

Exhibit 2.2-90 Photomicrographs of Various Regions in Exhibit 2.2-89

Exhibit 2.2-91 Magnified Views of Slag Pockets in Exhibit 2.2-90 (Slag pockets are dark gray and contain angular iron-rich precipitates (white)

Exhibit 2.2-92 Electron Probe Photomicrographs of (A) in Exhibit 2.2-89

Exhibit 2.2-93 Electron Probe Photomicrographs of (B) in Exhibit 2.2-89

2.2-102

Exhibit 2.2-94 Electron probe photomicrographs of (C) in Exhibit 2.2-89

Exhibit 2.2-95 Cross-section of a Monofrax Crucible Containing Illinois \# 6 Coal Slag after Heating to $1450^{\circ} \mathrm{C}\left(2642^{\circ} \mathrm{F}\right)$ for 100 hours in Air.

Exhibit 2.2-96 Electron Probe Photomicrographs of a Vertical Section through the Crucible in Exhibit 2.2-95

Exhibit 2.2-97 Graphs Indicating the Shrinkage of Plicast 99 versus Temperature for Two Samples Originally Containing Organic Fibers, and One Sample that did not Contain the Fibers

Exhibit 2.2-98 Scanning Electron Microscope Image Showing the Porosity of Plicast 99 Containing Organic Fibers and Fired at $2012^{\circ} \mathrm{F}\left(1100^{\circ} \mathrm{C}\right)$

Exhibit 2.2-99 Scanning Electron Microscope Image Showing the Reduced Porosity of Plicast 99 Containing Organic Fibers and Fired at $2732^{\circ} \mathrm{F}\left(1500^{\circ} \mathrm{C}\right)$

Exhibit 2.2-100 Scanning Electron Microscope Image Showing the Porosity in Plicast 99 not Containing Organic Fibers and Fired at $2732^{\circ} \mathrm{F}\left(1500^{\circ} \mathrm{C}\right)$

Exhibit 2.2-101 Scanning Electron Electron Microscope Image Showing the Shape of Pores in Plicast 99 Containing Organic Fibers and Fired at $2732^{\circ} \mathrm{F}\left(1500^{\circ} \mathrm{C}\right)$

Exhibit 2.2-102 Scanning Electron Microscope Image Showing the Shape of Pores in Plicast 99 not Containing Organic Fibers and Fired at $2732^{\circ} \mathrm{F}\left(1500^{\circ} \mathrm{C}\right)$

Exhibit 2.2-103 Graph Showing the Corrosion Rates of the Original Plicast 99 Block, Monofrax M, and a new Plicast 99 Block with Illinois No. 6 Slag at $2732^{\circ} \mathrm{F}\left(1500^{\circ} \mathrm{C}\right)$

Exhibit 2.2-104 Composition of Slags Over Time as Determined by X-Ray Fluorescence

Exhibit 2.2-105 Graph Showing the Corrosion Rates of the plicast 99 Block with Illinois no. 6 Slag and Illinois No. 6 Slag with 5\% Alumina Addition at $2732^{\circ} \mathrm{F}\left(1500^{\circ} \mathrm{C}\right)$

Exhibit 6-1 FT8 Gas \& All-Coal (HITAF) Repowering Performance 6-2

Exhibit 6-2 FT4000 Gas \& Coal (HITAF) Performance (1 Engine) 6-3 Exhibit 6-3 Preliminary Schematic of All Coal Repowering with the FT8 $6-4$ 


\section{Executive Summary}

This report represents work carried out under contract DE-AC22-95PC95144 "Engineering Development of Coal-Fired High Performance Systems Phase II and III." The goals of the program are to develop a coal-fired high performance power generation system (HIPPS) that is capable of:

$\diamond \quad \geq 47 \%$ thermal efficiency (HHV)

$\diamond \quad$ NOx, Sox, and particulates $\leq 10 \%$ NSPS

$\diamond \quad$ coal providing $\geq 65 \%$ of heat input

$\diamond \quad$ all solid wastes benign

$\checkmark \quad$ cost of electricity $\leq 90 \%$ of present plant

Work reported in this report is from Task 2.1 HITAF Combustor, Task 2.2 HITAF Air Heaters, and Task 6 HIPPS Commercial Plant Design Update.

\section{Task 2.1 HITAF Combustor}

Work during the past quarter has concentrated on additional development of the capability to model the application of SNCR in coal-fired boilers. Two approaches have been developed. The first approach involves a redefinition of the gas streams, and the second involves utilization of previously computed $\mathrm{CO}$ profiles.

\section{Task 2.2 HITAF Air Heaters}

The pilot-scale SFS was operated twice in support of the current program effort, but were funded by the North Dakota Industrial Commission (NDIC) and U.S. Department of Energy Federal Energy Technology Center (FETC).

\begin{tabular}{|l|l|l|}
\hline Dates & Coal Type & Purpose \\
\hline $\begin{array}{l}\text { April } \\
19-24\end{array}$ & $\begin{array}{l}\text { Coal Creek } \\
\text { Falkirk Lignite }\end{array}$ & $\begin{array}{l}\text { evaluate the SRAH and LRAH panels while } \\
\text { firing lignite in the slagging furnace system } \\
\text { (SFS) at 100\% load }\end{array}$ \\
\hline $\begin{array}{l}\text { June } \\
7-12\end{array}$ & $\begin{array}{l}\text { Center lignite and } \\
\text { Coal Creek - } \\
\text { Falkirk Lignite }\end{array}$ & $\begin{array}{l}\text { evaluate the SRAH and LRAH panels while } \\
\text { firing lignite in the SFS at 100\% load }\end{array}$ \\
\hline
\end{tabular}

The following comments summarize the performance of each of the components and/or subsystems during the two EERC tests conducted during the quarter.

- The fuel feed system was operated in April (50 hr, Coal Creek-Falkirk lignite) and June (50 $\mathrm{hr}$, Center lignite) at nominal feed rates of 370 to $400 \mathrm{lb} / \mathrm{hr}$ (168 to $182 \mathrm{~kg} / \mathrm{hr}$ ) and 345 to 360 
lb/hr (157 to $163 \mathrm{~kg} / \mathrm{hr}$ ). In April, the Coal Creek-Falkirk lignite feed rate was affected by high and variable surface moisture that caused bridging in the feed hopper resulting in feed instability. During the June test period, Center lignite was the primary fuel used. The fuel feed rate was much more stable as a result of lower surface moisture. Coal Creek-Falkirk lignite was fired for about nine hours on the last day of the run. Again, periodic hopper bridging was experienced during this time period. However, these events were easily resolved using the air pulse system installed in May. During both lignite-fired test periods, adjustments to lignite feed rate were made to simply maintain a lignite firing rate of nominally 2.5 MMBtu/hr $\left(2.6 \times 10^{6} \mathrm{~kJ} / \mathrm{hr}\right)$ as fuel characteristics changed during the week. The resulting furnace temperature was nominally $2700^{\circ} \mathrm{F}\left(1483^{\circ} \mathrm{C}\right)$.

- The slagging furnace heatup rate during the April and June test periods was limited to $50^{\circ} \mathrm{F} / \mathrm{hr}$ $\left(28^{\circ} \mathrm{C} / \mathrm{hr}\right)$ and $150^{\circ} \mathrm{F} / \mathrm{hr}\left(83^{\circ} \mathrm{C} / \mathrm{hr}\right)$, respectively. During the week of April 19-24, the furnace was fired on Coal Creek-Falkirk lignite at $100 \%$ load. Once furnace heatup was completed, the total furnace-firing rate ranged from 3.0 to $3.4 \mathrm{MMBtu} / \mathrm{hr}\left(3.1\right.$ to $\left.3.5 \times 10^{6} \mathrm{~kJ} / \mathrm{hr}\right)$. At $100 \%$ load, furnace temperature was controlled at nominally $2700^{\circ} \mathrm{F}\left(1483^{\circ} \mathrm{C}\right)$, depending on total furnace firing rate, main burner firing rate, and main burner swirl settings. During the week of June $7-12$ the furnace was preheated to nominally $2700^{\circ} \mathrm{F}\left(1483^{\circ} \mathrm{C}\right)$ and furnace temperature was controlled at nominally $2700^{\circ} \mathrm{F}\left(1538^{\circ} \mathrm{C}\right)$.

- Over the course of the weeklong test periods completed in April and June, the slag tap plugged only once, during the June test. Inspection of the furnace refractory after the April and June operating periods indicated severe refractory deterioration. After the June test period, refractory replacement was necessary in the furnace exit and slag screen, and repairs were required above the RAH panels and the slag tap.

- The main and auxiliary burners performed well during the test periods completed in April and June. Main burner swirl adjustment was more than adequate to establish a stable flame when firing the two lignites. It appears that the slag observed flowing through the slag tap came from the slag screen and not down the walls of the furnace.

- Inspection of the slag screen after the lignite-fired (Coal Creek-Falkirk) test period in April showed more high-density refractory deterioration. Although no refractory replacement was required after the April test, some patching of the floor was necessary. Slag screen inspection after the June test period (Center lignite) indicated that the refractory deterioration was even more severe. The refractory in the floor was in poor condition, and the first three rows of tubes were eroded to a significant degree. Therefore, it will be necessary to replace the slag screen tubes and refractory before the next test planned for August.

- Total slag and ash recovery from the April and June test periods was $80 \%$ and $61 \%$, respectively. Slag recovery from the furnace, slag pot, and dilution/quench zone represented nominally $69 \%$ and $43 \%$ of the theoretical ash.

- Inspection of the dilution/quench zone after each lignite-fired test completed this past quarter showed some slag deposits had formed in the vicinity of the FGR nozzles. However, it was not necessary to dislodge slag deposits from the dilution/quench zone during either week of operation. Downstream of the FGR nozzles, the small quantity of ash observed on the refractory walls was weakly sintered. 
- Even though the cooling air preheater heat-transfer rate degraded with time as ash deposits developed on the tube surfaces, cooling air temperature and flow rate control were adequate to support operation of the CAH tube bank and the LRAH panel.

- Particulate collection efficiency was roughly $99.9 \%$ when the Coal Creek-Falkirk lignite was fired in April and roughly 99.3\% when the Center lignite was fired in June.

- In the April test with Coal Creek-Falkirk lignite, heat recovery from the CAH tube bank decreased from roughly $45,000 \mathrm{Btu} / \mathrm{hr}(47,475 \mathrm{~kJ} / \mathrm{hr})$ to $12,500 \mathrm{Btu} / \mathrm{hr}(13,188 \mathrm{~kJ} / \mathrm{hr})$ as ash deposits developed on the tube surfaces. In the June test with Center lignite, heat recovery stabilized at $25,200 \mathrm{Btu} / \mathrm{hr}(26,586 \mathrm{~kJ} / \mathrm{hr})$. In general, the ash deposits resulting from the Center lignite test were stronger than those observed following the Rochelle subbituminous coal and the Coal Creek-Falkirk lignite tests

- The LRAH panel was thoroughly inspected following each week of operation. Upon inspection, the ceramic tiles appeared to be intact, however, all seven tiles/bricks had one or more visible cracks on the surface. Many of the cracks previously observed are no longer visible because of the slag/refractory layer on the surface of the tiles/bricks.

- To date, the LRAH panel has been exposed to a range of furnace-firing conditions for a total of $726 \mathrm{hr}$. Natural gas firing represents $457 \mathrm{hr}$ and coal-lignite firing represents $269 \mathrm{hr}$. The longest continuous coal-fired period was $80 \mathrm{hr}$, completed in March 1998. In addition, the LRAH panel has been exposed to seven heatup and cooldown cycles.

- For the April test period, the heat recovered from the LRAH panel during coal firing was 88,300 to 93,600 and 78,700 to $93,100 \mathrm{Btu} / \mathrm{hr}(93,156$ to 98,748 and 83,028 to $98,220 \mathrm{~kJ} / \mathrm{hr}$ ) for CA flow rates of 200 and $180 \mathrm{scfm}\left(5.7\right.$ and $\left.5.1 \mathrm{~m}^{3} / \mathrm{min}\right)$, respectively. For the June test period, the heat recovered from the LRAH panel during coal firing was 91,350 to 106,700 and 87,500 to $94,200 \mathrm{Btu} / \mathrm{hr}(96,374$ to 112,568 and 92,312 to $99,381 \mathrm{~kJ} / \mathrm{hr})$ ) for CA flow rates of 200 and $180 \mathrm{scfm}\left(5.7\right.$ and $\left.5.1 \mathrm{~m}^{3} / \mathrm{min}\right)$, respectively. As expected, temperatures and flow rates were very stable for individual test periods once furnace conditions and CA flow rates were stabilized.

- In the SRAH, although nearly all of the tiles/bricks show some degree of cracking that may be an indication of structural strength problems, there is no evidence at this time of impending failure of any of the individual ceramic tiles/bricks. Therefore, there are no plans to replace any SRAH panel tiles/bricks before the next test period scheduled in August.

- To date, the SRAH panel has been exposed to a range of furnace-firing conditions for a total of $283 \mathrm{hr}$. Natural gas firing represents $181 \mathrm{hr}$ and lignite firing represents $102 \mathrm{hr}$. The longest continuous lignite-fired period was $50 \mathrm{hr}$, completed in April 1998. In addition, the SRAH panel has been exposed to two heatup and cooldown cycles.

Several experimental compositions of fused cast refractories for the large RAH radiation tiles (hot lining) were developed by Monofrax Inc. Slag tests performed at Monofrax Inc., showed that the ACF-10 composition had far superior corrosion resistance to the Illinois slag over the other compositions developed. It also had a high emissivity and relatively high thermal conductivity. Employing a four point flexural strength test of the ACF-10 material, it was determined that the material retains its strength to $1371^{\circ} \mathrm{C}\left(2500^{\circ} \mathrm{F}\right)$. At this temperature it is 
stronger than the Monofrax M and K-3, which indicates that it has adequate strength for use as radiation tiles in the RAH.

Under the conditions of exposing the Monofrax top panel of the large RAH to the Illinois \# 6 coal slag for approximately 140 hours and to a sub-bituminous coal slag for approximately 32 hours in the Pilot Test Facility, the Monofrax $\mathrm{M}\left(\alpha / \beta \mathrm{Al}_{2} \mathrm{O}_{3}\right)$ material held up quite well. The original surface that was exposed remained intact, except for a few regions were the flowing slag wore a thin stream pattern down the vertical-face of the tile. The penetration of the slag into the interior regions followed open voids and microcracks into the original material and was limited to a depth of 5-6 mm. Penetration was deeper in the larger surface cracks, but the overall reaction of the slag with the fused cast alumina particles was not severe. The same results were observed for a Monofrax M crucible that contained the molten Illinois \# 6 slag at $1450^{\circ} \mathrm{C}$ for 100 hours in air.

Two dilatometer tests indicated why Plicast 99 (the hard-face castable refractory used in the SFS) that contained organic fibers had a much higher permanent shrinkage than the sample that contained no fibers. The greater shrinkage in the Plicast with the fibers is due primarily to the sintering of the pores left after the burnout of the organic fibers and, less to the alumina phase transitions. Therefore, in order to reduce the amount of shrinkage observed in larger-scale applications of the Plicast 99, it will be necessary to reduce the amount of fibers in the raw material.

\section{Task 6 HIPPS Commercial Plant Design Update}

The investigation of repowering an existing steam powerplant with an all coal configuration continued For these analyses, a plant with an output of approximately $122 \mathrm{MW}$ at 1450 psi and $1000 \mathrm{~F} / 1000 \mathrm{~F}$ and an efficiency of $35 \%$ is being used. Preliminary results indicate that efficiencies of FT8 repowered plants would vary from about $40 \%$ for a four-engine system at $1800 \mathrm{~F}$ to about $43 \%$ for a similar system at $2100 \mathrm{~F}$

Preliminary investigations to identify advanced HIPPS configurations with efficiencies approaching 60\% (LHV) has identified a Cascaded Humidified Advanced Turbine (CHAT) cycle with an efficiency over $55 \%$ (HHV) or nearly $60 \%$ LHV. Also, a HIPPS/HAT cycle has been identified with an efficiency of approximately 55\% (HHV) or about 59\% LHV. 


\section{Introduction}

The High Performance Power Systems (HIPPS) electric power generation plant integrates a combustion gas turbine and heat recovery steam generator (HRSG) combined cycle arrangement with an advanced coal-fired boiler. The unique feature of the HIPPS plant is the partial heating of gas turbine (GT) compressor outlet air using energy released by firing coal in the high temperature advanced furnace (HITAF). The compressed air is additionally heated prior to entering the GT expander section by burning natural gas. Thermal energy in the gas turbine exhaust and in the HITAF flue gas are used in a steam cycle to maximize electric power production. The HIPPS plant arrangement is thus a combination of existing technologies (gas turbine, heat recovery boilers, conventional steam cycle) and new technologies (the HITAF design including the air heaters, and especially the heater located in the radiant section).

The HITAF provides heat to the compressor outlet air using two air heaters, a convective air heater $(\mathrm{CAH})$, and a radiant air heater $(\mathrm{RAH})$. The HITAF is a slagging furnace which contains the radiant air heater, as well as waterwalls and steam drum for the high pressure (HP) steam system. Hot flue gas leaving the HITAF furnace passes over the CAH prior to entering a heat recovery steam generator (HRSG). Hot exhaust gas from the gas turbine is ducted to another HRSG in a typical combined cycle arrangement. The HITAF, gas turbine and HRSGs are configured to achieve the required high efficiency of the HIPPS plant.

The key to the success of the concept is the development of integrated combustor/air heater that will fire a wide range of US coals with minimal natural gas and with the reliability of current coal-fired plants. The compatibility of the slagging combustor with the high temperature radiant air heater is the critical challenge. 


\section{Task 2.1 HITAF Combustor}

\section{Model Pilot Dilution/Convective Heater/SNCR}

Work during the past quarter has concentrated on additional development of the capability to model the application of SNCR in coal-fired boilers. Temperature plays a large role in determining the performance of SNCR in NOx reduction, whether the reagent is ammonia, urea, or cyanuric acid. If the temperature is too low $\left(<1700{ }^{\circ} \mathrm{F}\right)$, then unreacted reagent slips through and commonly reacts with other species downstream and can result in air heater pluggage. If the temperature is too high $\left(>2300{ }^{\circ} \mathrm{F}\right)$, the reagent itself can be oxidized to form additional NOx. So, flue gas temperature has an order one significance in the SNCR process.

Gas composition is also important in the SNCR process. Obviously NOx and SNCR reagent concentrations are important since the rates of reduction and oxidation directly depend on them. Indirectly, $\mathrm{CO}$ concentration also plays a large role in the rates governing SNCR chemistry. CO acts to lower the temperature window in which SNCR chemistry acts to reduce NOx. When CO levels are high, it is important to accurately account for this effect. Previous work was done (Brouwer, et al., Twenty-sixth symposium (International) on Combustion, 1996) to account for the effect of $\mathrm{CO}$ on the reduced SNCR chemistry. However, due to the number of different streams involved in the SNCR process (water, urea, air, fuel), approximations must be made to model the problem since the number of streams currently allowed in the CFD software is limited to three.

Typically, SNCR simulations have assumed that the flue gas composition is uniform at the inlet to the upper furnace, where the SNCR reagents are injected. This is a reasonable assumption in many cases since mixing and reaction are relatively complete by the time the flue gas reaches the upper furnace. However, in some cases, such as when separated overfire air injection is used, mixing is not complete, and significantly large variations in $\mathrm{CO}$ can exist in the regions where SNCR reagents are injected. In this case, it is important to represent not only the high average level of $\mathrm{CO}$ concentration, but also the distribution of $\mathrm{CO}$.

A difficulty in accounting for the variable distribution of $\mathrm{CO}$ in the model is related to the number of independent streams that are allowed. In modeling SNCR in a coal fired boiler, these streams are typically:

1) water vapor from urea droplets,

2) gas phase urea products, and

3) flue gas.

This definition does not allow for the significant spatial variability in $\mathrm{CO}$ concentration that can exist through mixing limitations between fuel and air since fuel and air streams are not separately modeled with this approach.

Two approaches have been developed to overcome this difficulty. The first approach involves a redefinition of the gas streams, and the second involves utilization of previously computed $\mathrm{CO}$ profiles. Since the amount of water evaporated from the urea droplets is relatively small compared to the total flue gas flow $(<1 \%)$, it is a reasonable approximation not to track its mass 
in the gas phase. This compromise allows tracking air and fuel streams separately, providing a way to model mixing limitations between the fuel and air. In particular, the variable CO distribution at the inlet can be accounted for in this manner.

Some problems have been encountered with this approach; they are currently being examined. Since the definition of the mixture fractions in the lower furnace simulations differs from that of the upper furnace, the variation of $\mathrm{CO}$ computed in the upper furnace quantitatively varies from that computed in the lower furnace. In addition, the injected reagent streams appear to increase the $\mathrm{CO}$ concentration in the injection region for an, as yet, unexplained reason. Solutions to these problems are currently being investigated.

Another approach which has been developed involves three-dimensional interpolation from the "lower furnace" simulation. Modeling SNCR injection in coal-fired boilers typically requires the decomposition of the boiler into a "lower" and "upper" furnace. The large physical size of the boiler coupled with the CPU limitations regarding mesh size constrain the extent of the boiler that can be modeled within one simulation. The lower furnace typically extends from the ash hopper up to the vertical plane at the nose immediately upstream of the convective passes. The upper furnace typically extends from below the lowest set of SNCR injectors, up through the convective passes and into the economizer. Thus, results from the lower furnace case are interpolated onto the upper furnace case at a common plane. The plane where the interpolation occurs is typically in the vicinity of the boiler nose, and must be located upstream of the SNCR injection ports. The variables that are interpolated include the velocity components, the gas temperature, the mixture fraction, and coal gas mixture fraction. The definitions of the mixture fraction and coal gas mixture fraction depend on the stream definitions in the upper furnace as discussed in the preceding paragraph.

Since CO concentration is a dependent variable in the simulation (it depends on the local mixture fraction, coal gas mixture fraction, and heat loss), its distribution is typically not explicitly interpolated from the lower furnace simulation. It is recomputed in the upper furnace simulation based on the new values of the mixture fractions and heatloss. However, the CO concentration computed in each cell in the lower furnace simulation could be used in the upper furnace SNCR chemistry calculations. This is the basis of the second approach. This involves performing a three-dimensional interpolation of the $\mathrm{CO}$ values from the lower furnace simulation onto the upper furnace grid. These values are only used as inputs to the post process SNCR calculations. The dependence of the SNCR chemistry on the local CO concentration is taken into account as described by Brouwer (Brouwer, et al., Twenty-sixth symposium (International) on Combustion, 1996), through adjustments to the activation energy in specified rate equations. This second approach does not require that the evaporated water from the urea droplets be neglected as does the first approach. In addition, there is no difference between the $\mathrm{CO}$ distribution computed in the lower furnace simulation and that used in the SNCR chemistry, as has been when the first approach is used.

The above-described modifications to account for CO variation in the SNCR chemistry are considered to be short-term modifications. Through another program, REI is currently working with Professor J.Y. Chen of U.C., Berkeley in the development of reduced mechanisms. He has developed software (computer assisted reduced mechanism code (CARM)) that automates the process of generating reduced chemical mechanisms for detailed hydrocarbon combustion. REI also plans to work with him as part of this program in regards to the development of a more 
robust reduced mechanism for SNCR, that explicitly accounts for the dependence on CO concentration. 


\section{Task 2.2 HITAF Air Heaters}

In the previous quarterly report results from the pilot scale testing at UND/EERC through February 1998 were presented in the section. (EERC reported on the March test in the previous report in the section on Pilot-Scale Testing.) There have been three more tests since February.

\begin{tabular}{|l|l|l|}
\hline Month & Coal Type & Heat Exchangers Tested \\
\hline March & Rochelle Subbituminous & Large RAH, CAH \\
\hline April & Coal Creek - Falkirk Lignite & Large RAH, Small RAH, CAH \\
\hline June & Center Lignite & Large RAH, Small RAH, CAH \\
\hline
\end{tabular}

The results of these three tests are reviewed in this report. The following section discusses the thermal performance of each heat exchanger: CAH, Large RAH, and Small RAH.

\section{CAH Results}

The CAH continues to perform as it did in the original tests last year. It starts with its nominal capacity, and then decays as ash builds up on its tubes. As will be shown with the following plots, there is a significant difference between the temperature of the air that leaves the bayonet style tubes and enters the header, and the temperature of the air as it leaves the CAH header and enters the pipes. For the purpose of heat transfer analysis it is only important to analyze the internal heat transfer within the tubes. The header design is particular to this pilot test, and would need to be better insulated for a commercial design because there are significant heat leaks both from the air to the outside ambient, and between the entering and leaving air.

The following exhibits show raw data for the April test, and the heat flux data for the March, April and June tests. The net heat flux is shown as measured both externally and internally as defined below:

$$
\dot{Q}=\left(\rho_{s}=0.076\right)\left(c_{p}=0.262\right)(S C F M)(60 \mathrm{~min} / \mathrm{hr}) \Delta T
$$

where $\Delta \mathrm{Ts}$ are defined as:

$$
\begin{aligned}
\Delta T_{\text {int }} & =(C A H T C 5+C A H T C 6+C A H T C 7+C A H T C 8) / 4-(C A H T C 2+C A H T C 3) / 2 \\
\Delta T_{\text {ext }} & =T C 640-T C 638
\end{aligned}
$$

The instrumentation for the $\mathrm{CAH}$ is described elsewhere in this report (Exhibits 2.2-47 and 2.2-48) and in previous reports.

[It should be noted that EERC defined the CAH performance as based on

$$
\Delta T_{\text {int }}=(C A H T C 5+C A H T C 6+C A H T C 8) / 3-(C A H T C 1)
$$

which produces slightly higher flux values (see discussion under Task 2.2 HITAF Air Heaters/Pilot-Scale Testing/Testing of the CAH Tube Bank).] 


\section{$\underline{\text { Raw Temperature Plots - April Test }}$}

\section{Exhibit 2.2-1 \\ Flue Gas \& Air Temperatures}

This plot shows the flue gas temperature before and after the $\mathrm{CAH}$, and air temperature in and out as measured in the external pipes leading to and from the CAH header (left axis). In addition, the $\mathrm{CAH}$ air flow rate is shown (right axis). At 70 hours into the test there is no net heat gain from the $\mathrm{CAH}$.

\section{Exhibit 2.2-2 Exit Air Temperatures}

This plot compares the air temperatures leaving 4 of the 7 active tubes, and that leaving the header. The lead tube (CAHTC5) is considerably hotter than the others. The header out temperature (TC640) is not the average of the tube temperatures, but shows a significant loss of heat from the header.
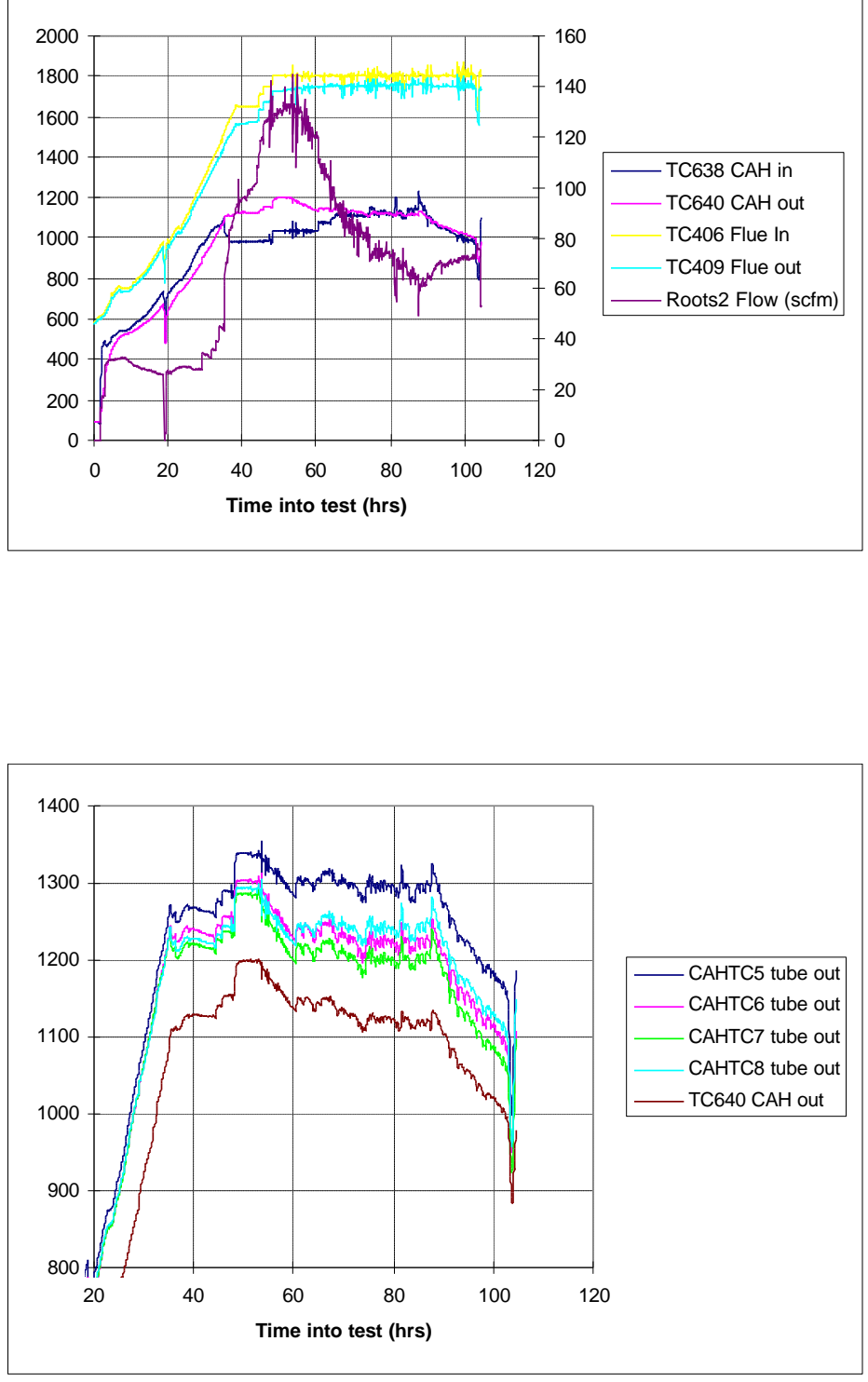


\section{Exhibit 2.2-3 Inlet \& Shell Surface Temperatures}

This plot shows the inlet temperatures as well as the shell surface temperature. Initially there is a gain in temperature from the header inlet (TC638 \& CAHTC1) to the tube inlets (CAHTC2 \& CAHTC3), but as the test continues there is a loss.

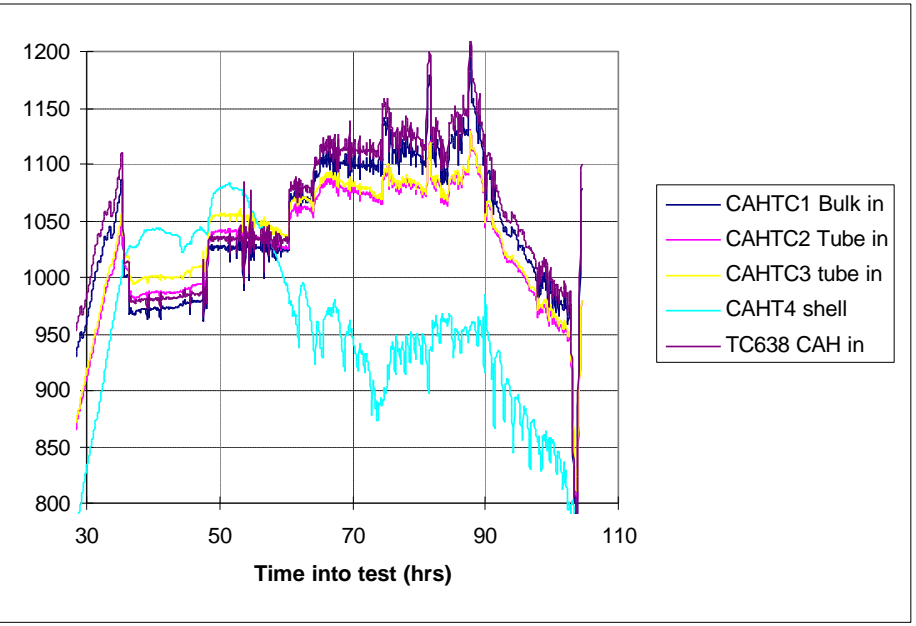

Heat Flux Plots - April, March, and May Tests

\section{Exhibit 2.2-4 \\ Net Heat Flux \\ - April Test}

This plot shows the net heat flux gained both as measured externally to the $\mathrm{CAH}$, and internally to the tubes as defined in the above equations.

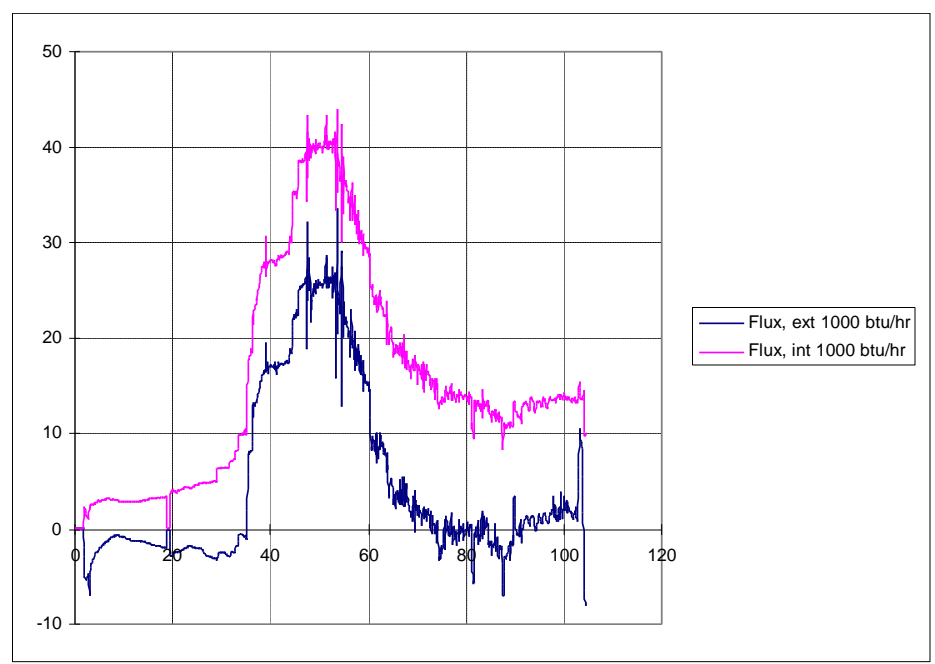




\section{Exhibit 2.2-5 \\ Net Heat Flux \\ - March Test}

This plot shows the net heat flux gained both as measured externally to the $\mathrm{CAH}$, and internally to the tubes. This plot clearly shows the two times that tube cleaning was performed at 60 and 93 hours.

\section{Exhibit 2.2-6 Net Heat Flux - June Test}

This plot shows the net heat flux gained both as measured externally to the $\mathrm{CAH}$, and internally to the tubes (left axis). Also shown on this plot is the coal feed rate (right axis). Unlike previous tests, there is a period of operation with coal firing when the performance does not continue to degrade.
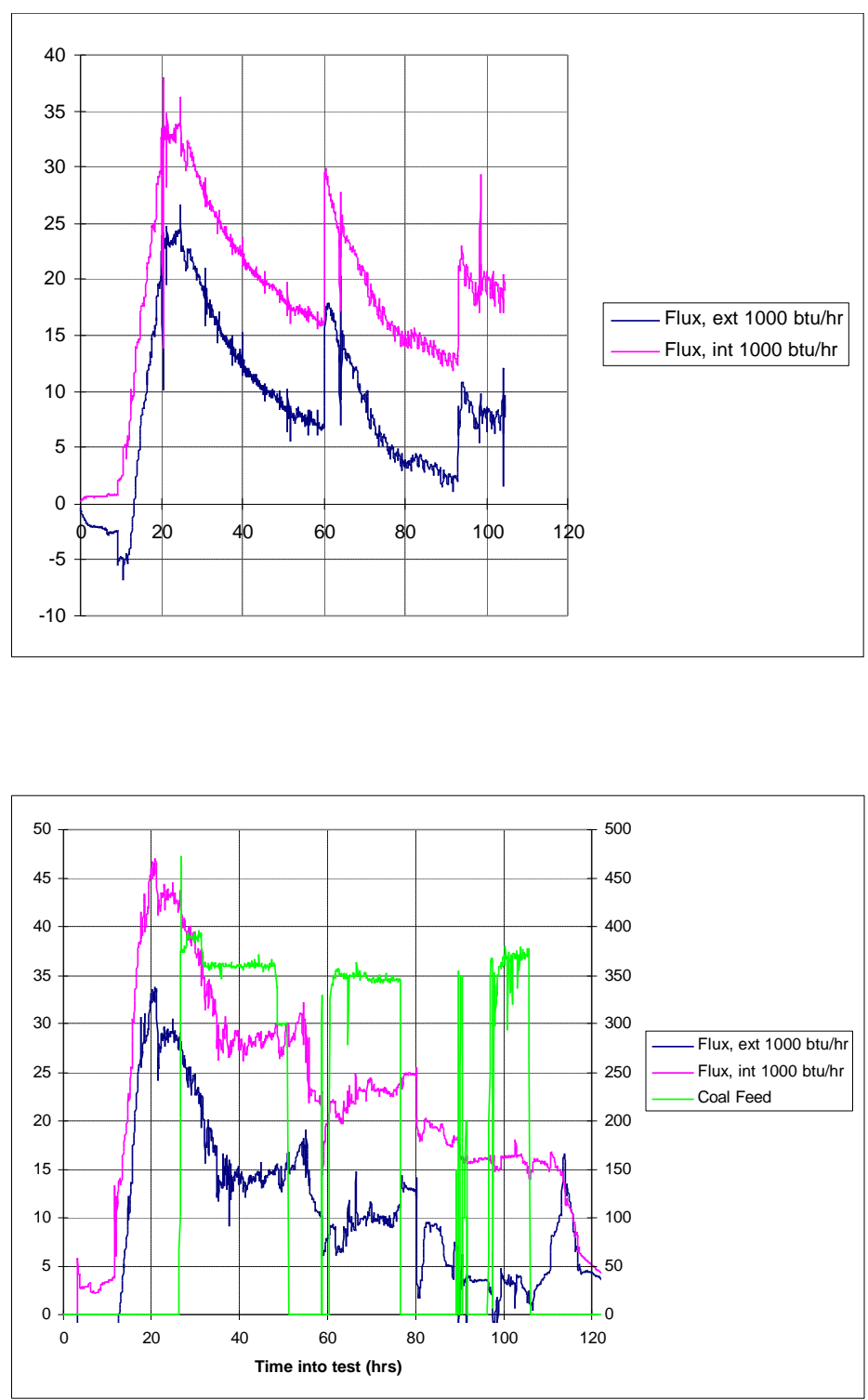


\section{Large RAH Results}

The instrumentation for the large RAH (LRAH) is described elsewhere in this report (Exhibit 2.2-65 and 2.2-66), and in previous reports. In this section both raw data and processed data are presented to summarize the RAH performance for the March, April and June tests. The processed data includes total heat flux measurements and corresponding lumped heat transfer coefficient.

\section{March Raw Data}

\section{Exhibit 2.2-7 \\ Air Temperatures \& Air Flow Rate}

The entering and leaving air temperatures (left axis) are shown together with the LRAH air flow rate (right axis). The test was run with 3 different flow rates, 200, 180, and 150 $\mathrm{scfm}\left[340,306,255 \mathrm{sm}^{3} / \mathrm{hr}\right]$. As the air flow rate decreases, the leaving air temperatures (and to a less extent the entering air temperatures) can be seen to increase.

\section{Exhibit 2.2-8 Tube Temperature \& Coal Feed Rate}

The hottest part of the tubes (bottom facing furnace) are shown (left axis) together with the coal feed rate (right axis). It can be seen that each tube is at almost identical temperature. The coal feed was ON continuously for most this test. For the second half of the test, with constant air flow, a correlation can be seen between the coal feed rate and the tube temperatures.
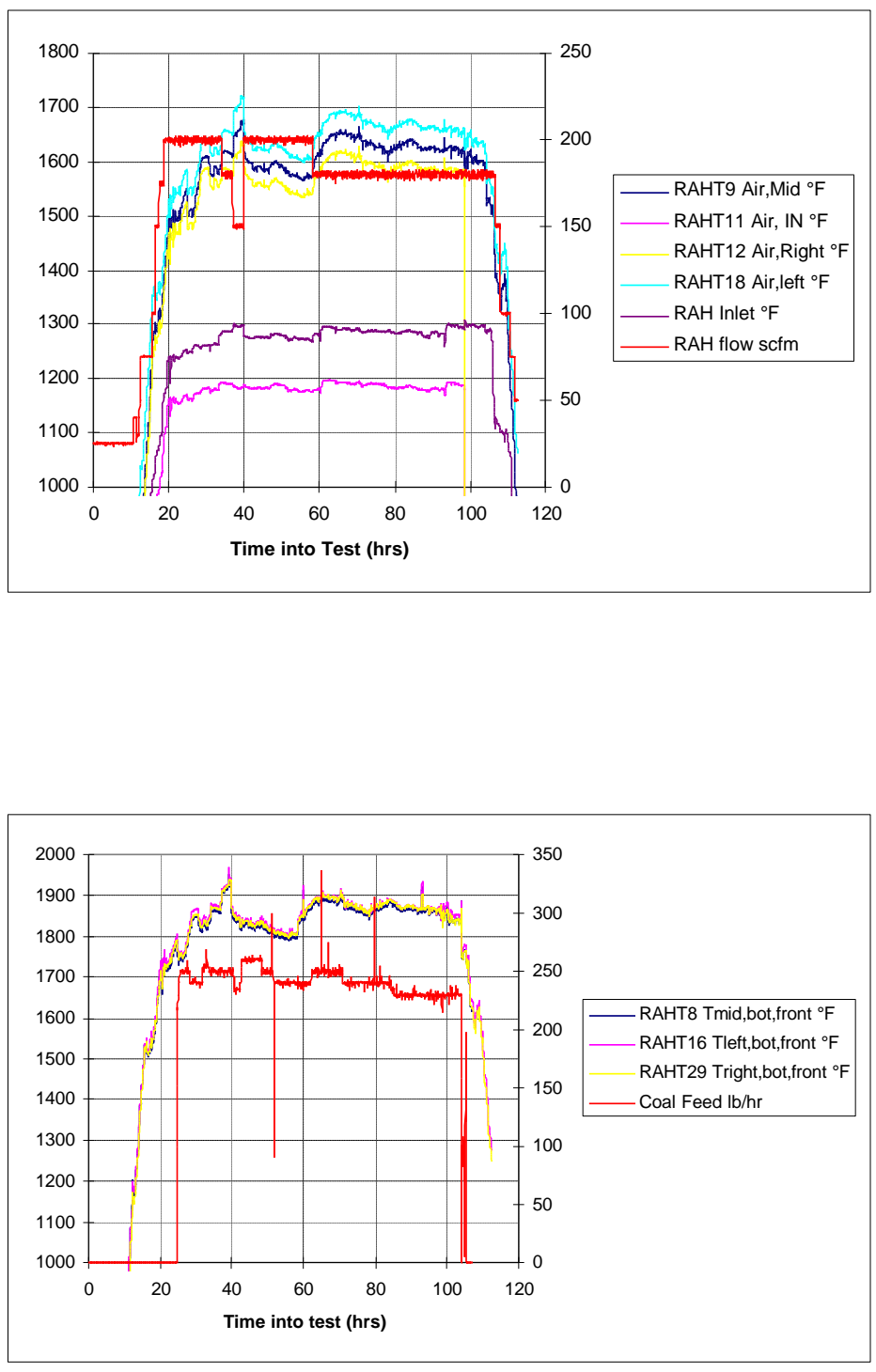


\section{Exhibit 2.2-9 \\ Air Flow \& Pressure Drop}

This plot show the relation between the LRAH air flow and its pressure drop through the LRAH tubes. The parabolic relation is typical of turbulent flows.

\section{April Raw Data}

\section{Exhibit 2.2-10 Air Temperatures \& Air Flow Rate}

The entering and leaving air temperatures (left axis) are shown together with the LRAH air flow rate (right axis). This test was run with two different flow rates, 200 and $180 \mathrm{scfm}$ [340 and $306 \mathrm{sm}^{3} / \mathrm{hr}$ ]. As can be seen, the temperatures were generally lower during this test than during the March test. Also, the leaving air temperature does not correlate well with the air flow rate.
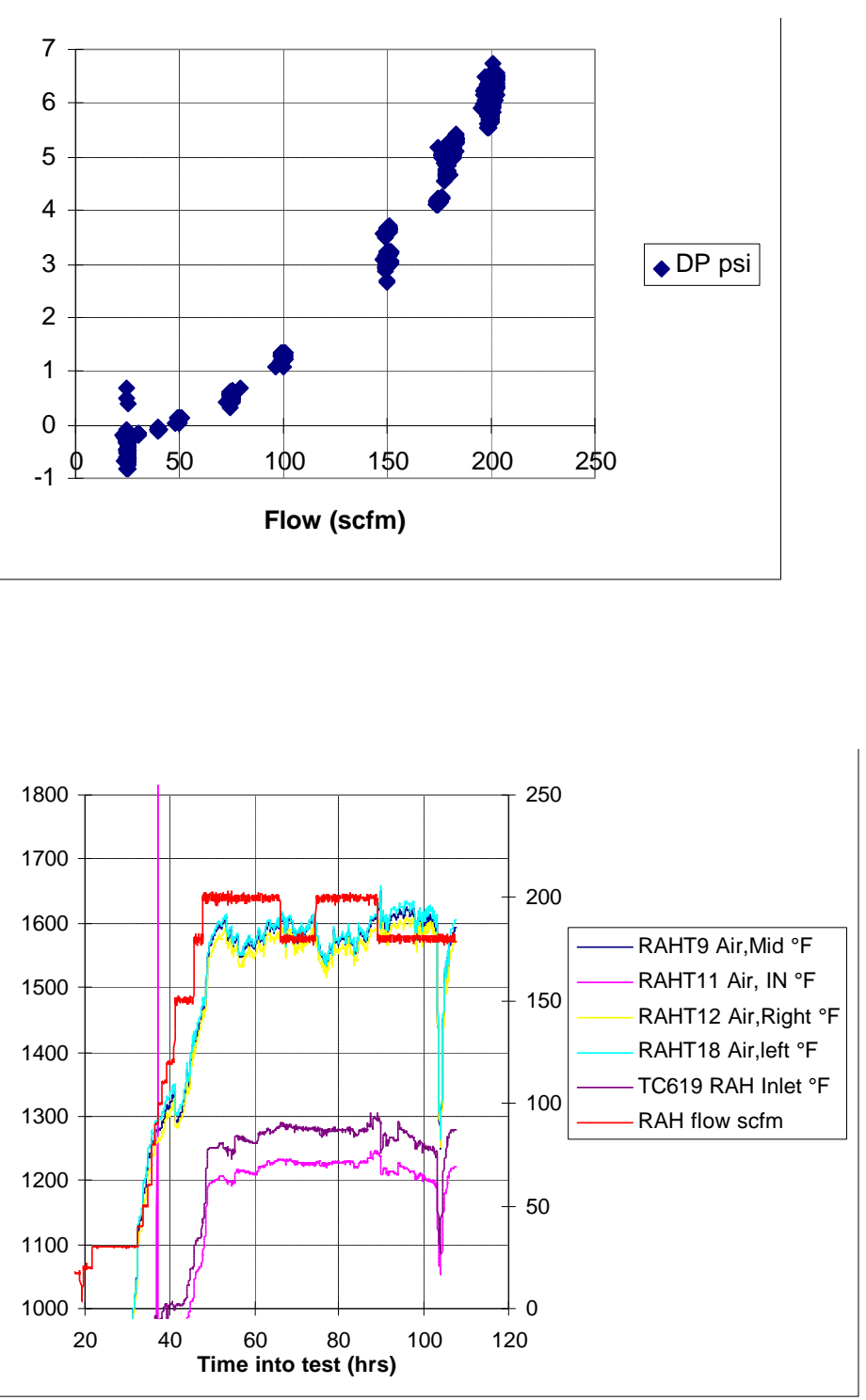


\section{Exhibit 2.2-11 \\ Tube Temperature \& Coal Feed Rate}

The hottest part of the tubes (bottom facing furnace) are shown (left axis) together with the coal feed rate (right axis). It can be seen that each tube is at the same temperature, and that they are considerably cooler than the previous test. The coal feed was on continuously until $103 \mathrm{hrs}$, and can be seen to be quite erratic.

\section{Exhibit 2.2-12 \\ Tube Temperature \& Coal Feed Rate (expanded)}

This plot is an expansion of the above plot for the time where the coal feed stopped and the gas did not come on for about one hour. The tube temperatures plummeted while there was no heat input, and then came quickly back up to their operational temperature after the gas was brought on.

\section{Exhibit 2.2-13 Brick Centerline} Temperatures (expanded)

This plot shows the same time period as the above plot for the brick centerline temperatures. From this and the previous plot the time constant of the heat exchanger can be seen to be quite fast.
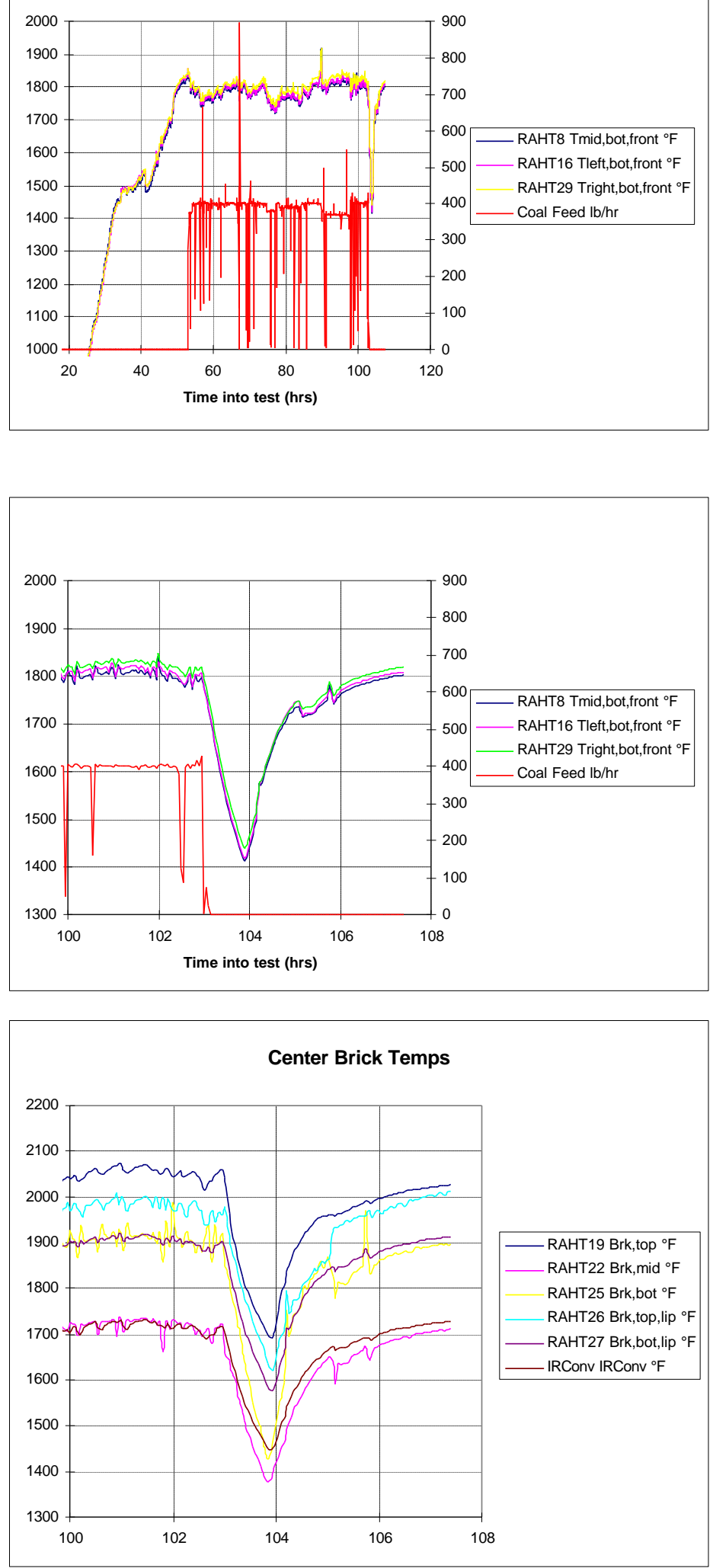


\section{June Raw Data}

\section{Exhibit 2.2-14 \\ Air Temperatures \& Air Flow Rate}

The entering and leaving air temperatures (left axis) are shown together with the LRAH air flow rate (right axis). This test was run with 2 different flow rates, 200 and $180 \mathrm{scfm}$ [340 and $306 \mathrm{sm}^{3} / \mathrm{hr}$ ]. As in the previous test there is little correlation between the air flow rate and the leaving air temperature. The higher temperatures achieved at several times during the test most likely result from fuel input and flame variations.

\section{Exhibit 2.2-15 \\ Tube Temperature \& Coal Feed Rate}

The hottest part of the left and right tubes (left axis) are plotted with the coal feed rate (right axis). (The middle tube sensor had failed for this test). The tube temperatures can be seen to be varying considerably during the test with the same patterns as the air temperatures above.
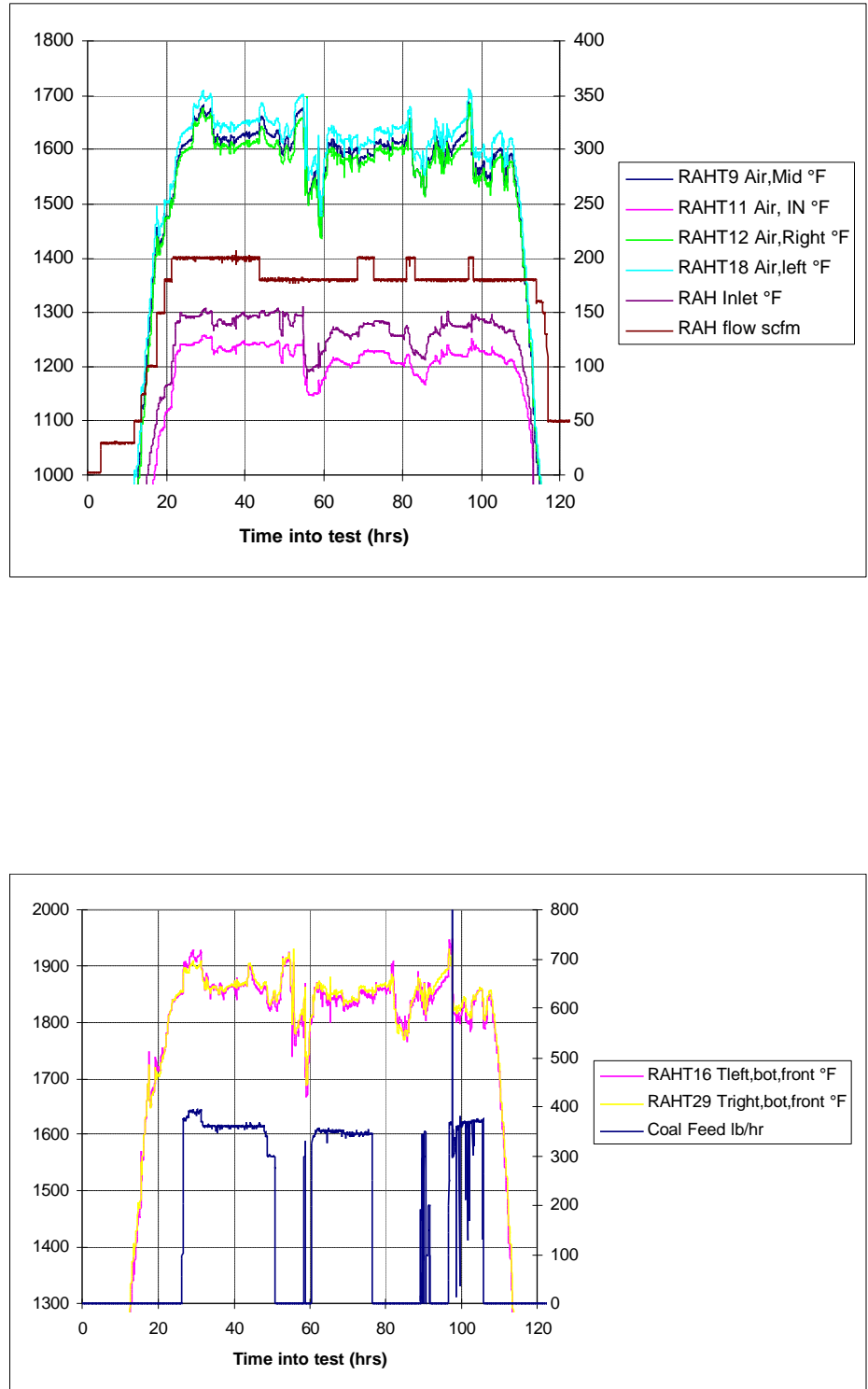


\section{Exhibit 2.2-16 Average Temperature Increase}

This plot shows the average increase in air temperature from inlet to outlet of the LRAH. The top trace (Avg1) goes from the inlet header connection pipe to the outlet header, while the bottom trace goes from the supply pipe to the outlet header. It can be seen that the temperature rise varied throughout the test, and generally did not correlate well with the air flow rate.

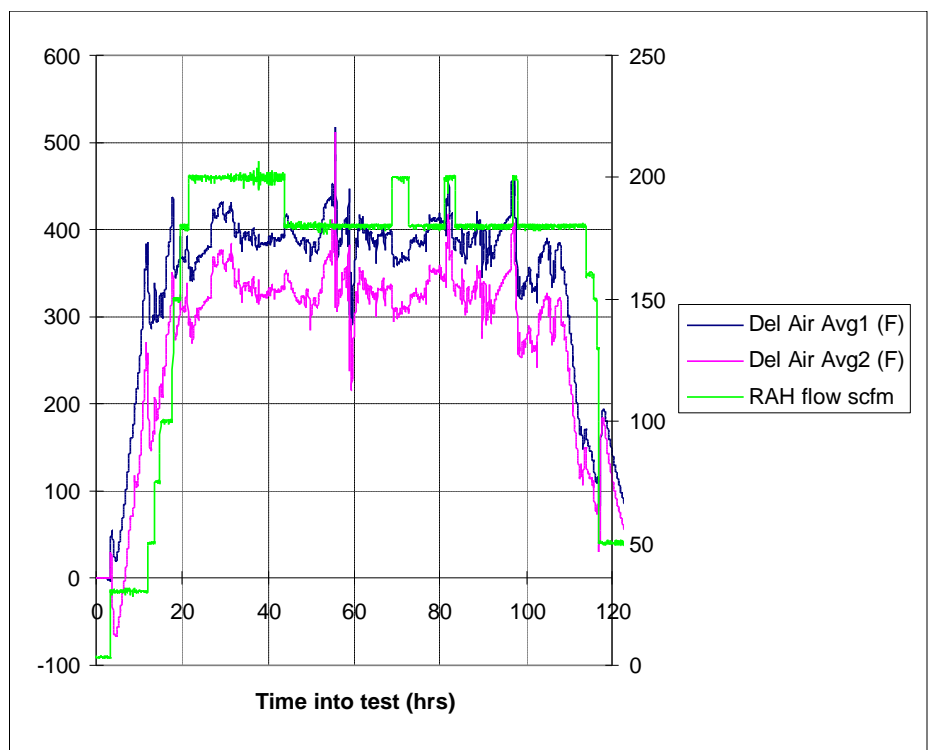

\section{General Summary}

The pilot scale large RAH was designed using the same codes and assumptions as was used to do the commercial plant design. The differences between the commercial design and the pilot scale design have mainly to do with the air-side, and have been discussed in previous reports.

A lumped analysis rates the heat exchanger with respect to its ability to exchange heat between the two fluid streams (in this case flue gas and air), and ignores the details of the internal resistances. An energy balance states that the heat transferred to the air is equal to its enthalpy flux.

$$
\dot{Q}=\dot{m} c_{p}\left(T_{\text {out }}-T_{\text {in }}\right)
$$

The heat flux can be expressed as:

$$
\dot{Q}=U A(L M T D)=\dot{m} c_{p}\left(T_{\text {out }}-T_{\text {in }}\right)
$$

where the Log-Mean-Temperature-Difference is used for the effective lumped temperature difference, and $U A$ is the lumped heat transfer conductance. The LMTD for constant flue gas temperature is defined as:

$$
L M T D \equiv \frac{T_{\text {out }}-T_{\text {in }}}{\ln \left|\left(T_{\text {flue }}-T_{\text {in }}\right) /\left(T_{\text {flue }}-T_{\text {out }}\right)\right|} .
$$

The lumped heat exchanger performance presented below was based on the above equations with the following inputs: 
Tin: $\quad$ RAHT11

Tout: $\quad$ RAHT9, 12,18

Tflue: Furnace Temps measured by EERC.

Cp: $\quad 0.276(\mathrm{btu} / \#-\mathrm{F})$ $[1.16 \mathrm{~kJ} / \mathrm{kg}-\mathrm{K}]$
Air entering RAH through center tube.

Average of three Air exit temperatures.

The effective flue temperature is assumed to be 2800

$\mathrm{F}[1540 \mathrm{C}]$ for the following calculations, although the actual temperature may have been lower, especially for the April and June tests. If a lower flue temperature were used, then the calculated UAs would be higher.

The specific heat of air at $1500 \mathrm{~F}$ [816 C]

Exhibit 2.2-17 summarizes the results of all three tests and compares it to the design calculations.

Exhibit 2.2-17

Comparison Between Design and Operation Conditions

\begin{tabular}{|l|c|c|c|c||c|c|}
\hline & $\begin{array}{l}\text { Time into } \\
\text { test (hrs) }\end{array}$ & $\begin{array}{c}\text { Air Flow } \\
(\mathrm{scfm})\end{array}$ & $\begin{array}{c}\text { T air in } \\
(\mathrm{F})\end{array}$ & $\begin{array}{c}\text { T air out } \\
(\mathrm{F})\end{array}$ & $\begin{array}{c}\mathrm{Q} \\
(\mathrm{Mbtu} / \mathrm{hr})\end{array}$ & $\begin{array}{c}\text { UA } \\
(\mathrm{btu} / \mathrm{hr}-\mathrm{F})\end{array}$ \\
\hline Design & $\mathrm{XX}$ & 195 & 1300 & 1700 & 98.3 & 76.2 \\
\hline \hline March \#1 & $34-$ to-36 & 180 & 1191 & 1618 & 97.0 & 70.1 \\
\hline March \#2 & 38 -to-39.5 & 150 & 1183 & 1662 & 90.4 & 66.3 \\
\hline March \#3 & $46-$ to-50 & 200 & 1186 & 1594 & 102.5 & 73.2 \\
\hline March \#4 & 64-to-68 & 180 & 1191 & 1651 & 104.1 & 76.2 \\
\hline \hline April & 87.5 -to-88.5 & 200 & 1241 & 1602 & 91.0 & 66.3 \\
\hline June \#1 & 70 -to-72 & 200 & 1228 & 1594 & 92.0 & 66.6 \\
\hline June \#2 & $74-$ to-76 & 180 & 1228 & 1613 & 87.3 & 63.7 \\
\hline
\end{tabular}

The total heat transfer rate and effective UA increased with increased flow rate, as expected. The April and June tests, with the Lignite coal, had lower heat transfer and UA than the March test with the subbituminous coal. A partial explanation of this can be seen in the furnace temperature plots (Exhibit 2.2-36 and 2.2-37). The effective furnace temperature was lower than $2800 \mathrm{~F}$ for the April test, and slightly lower for the June.

\section{Small RAH Results}

The purpose of the small RAH (SRAH) was not to test heat transfer, but to provide a heat exchanger where alternative brick designs and materials could be tested simultaneously with the LRAH. For this reason water cooling tubes were designed to produce the proper thermal gradient across the bricks. In addition, a center support rail and vertical overlap lips were designed to simulate the other issues concerning the commercial plant design. The heat transfer 
for the small RAH is measured from the temperature rise and flow rate of the cooling water. In general the small RAH heat transfer to the water tubes was successful in that the proper temperature gradient was generated to test the ceramic tiles.

The instrumentation for the small RAH is described elsewhere in this report (Exhibits 2.2-78 and 2.2-79), and in previous monthly reports.

\section{$\underline{\text { April Summary Results }}$}

\section{Exhibit 2.2-18 Brick Back Center Temperature}

This plot shows the back (coldside) center temperature of each active brick. It was the goal for these temperatures to be within the range of $2000 \mathrm{~F}$ when the furnace temperature was at 2800 F. It can be seen that they appear to be somewhat noisy. This is a result of the erratic coal feed rate.

\section{Exhibit 2.2-19 \\ Sensor Temperature Comparison}

This plot shows the temperatures of the two sensors which penetrated into the furnace, and the two which were inserted through holes which were drilled through the bricks to within $1 / 8$ inch [ $3 \mathrm{~mm}$ ] of the outer brick surface. Again, the temperatures are very noisy.
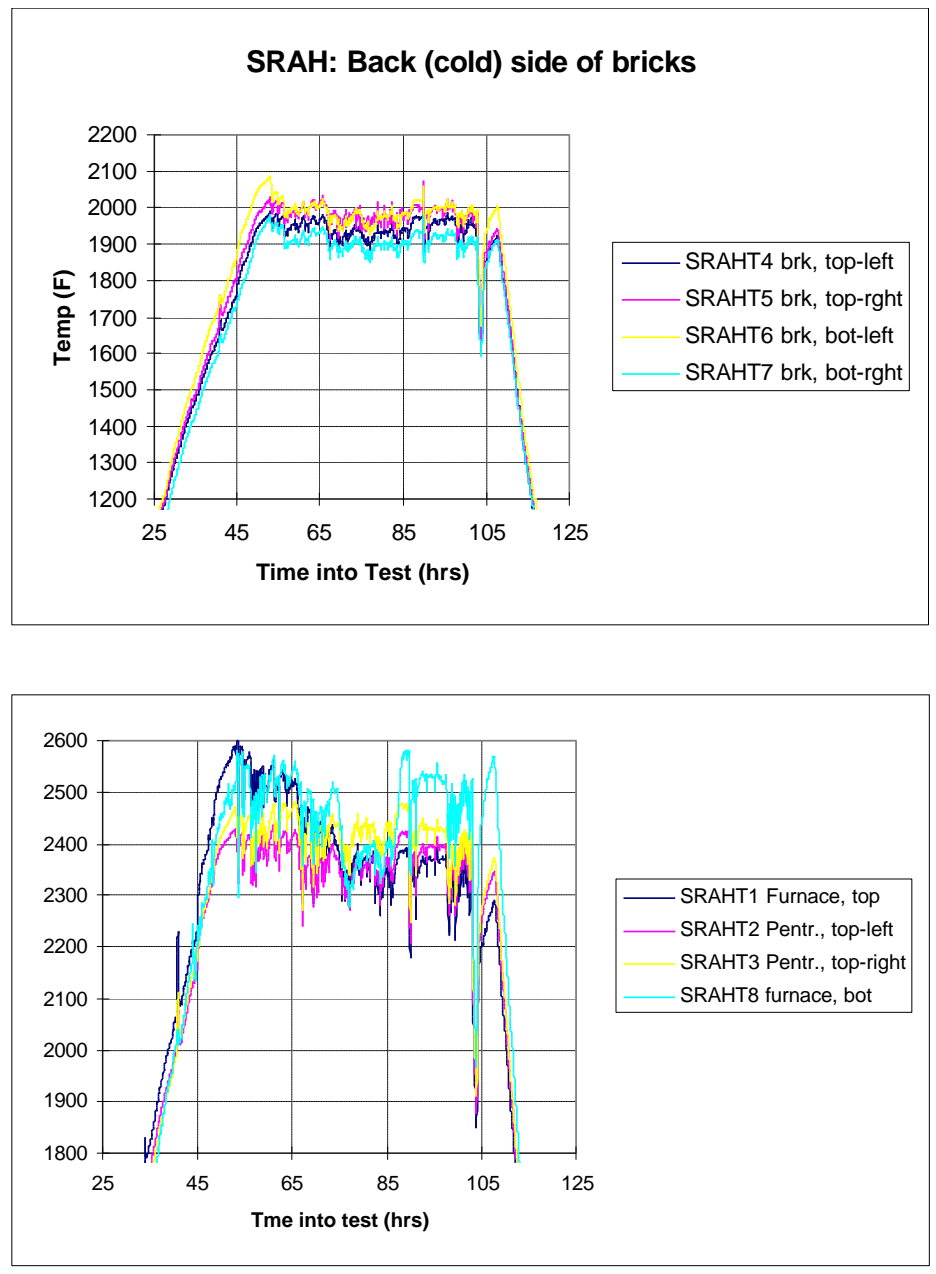


\section{Exhibit 2.2-20 \\ Sensor Temperature Comparison (expanded)}

This plot is an expansion of the above plot around the time when the coal turned off, and there was a delay before the gas came on. The fast time constant of this heat exchanger is evident.

\section{Exhibit 2.2-21 Cooling Water Temperature Increase}

This plot shows the rise in cooling water temperature for each side (cavity) of the small RAH.
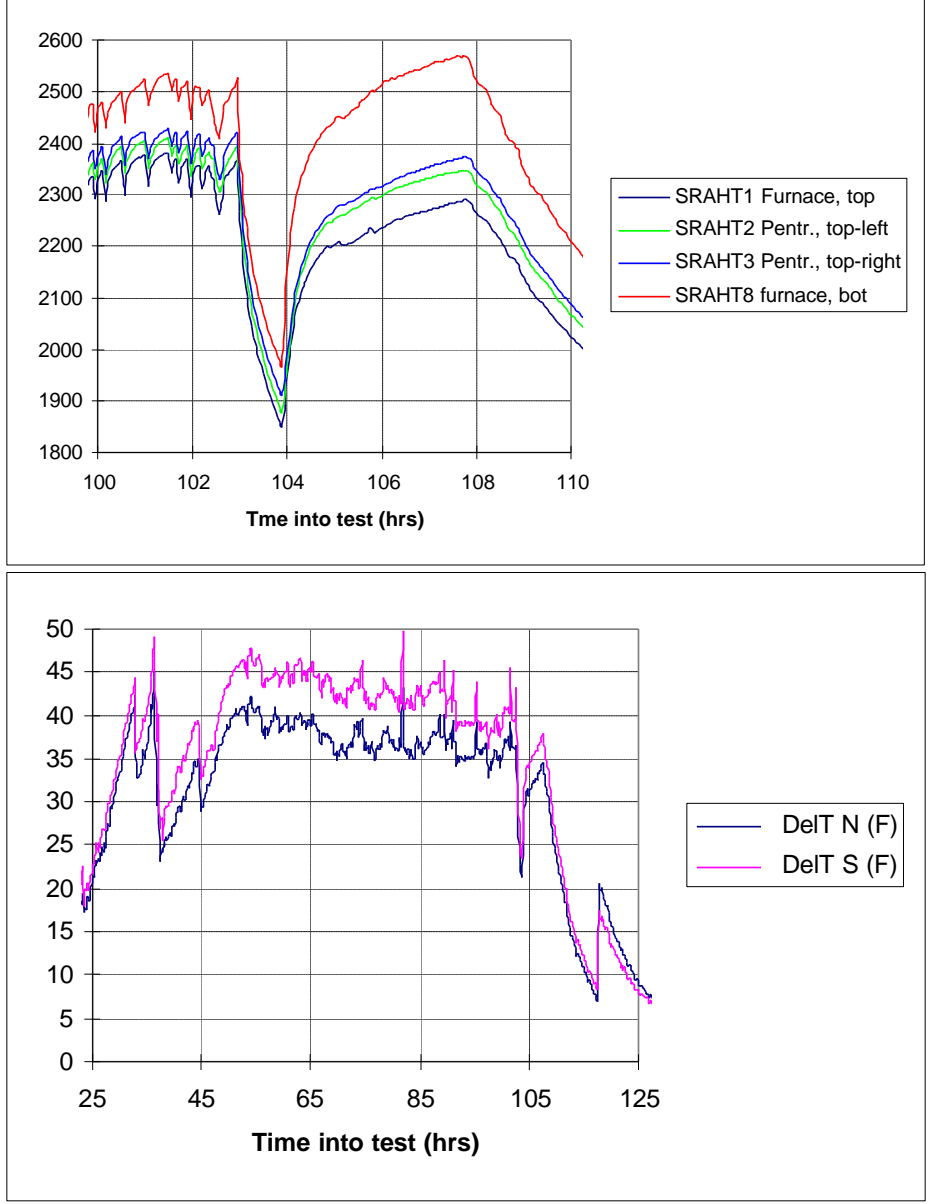

Through most of the test the water flow was maintained at $\sim 2.5 \mathrm{gpm}$ for each circuit. This equates to a total heat flux of:

$(5 \mathrm{gal} / \mathrm{min}) *(8 \# / \mathrm{gal}) *(60 \mathrm{~min} / \mathrm{hr}) *(1 \mathrm{btu} / \#-\mathrm{F}) *(\sim 40 \mathrm{~F})=96,000 \mathrm{btu} / \mathrm{hr}$ $[102,000 \mathrm{~kJ} / \mathrm{hr}]$.

This is greater than the expected flux through just the active ceramic bricks of $\sim 65,000 \mathrm{btu} / \mathrm{hr}$. It is likely that the water tubes are picking up additional heat from the "non-active" parts of the small RAH. 


\section{June Summary Results}

\section{Exhibit 2.2-22}

\section{Brick Back Center}

\section{Temperature}

This plot shows the back center temperature of 3 of the 4 active bricks. In the early part of the test these temperatures were higher than that obtained in April tests. By the end they were similar. The temperatures were much more constant during this test than the April test, due to better control of the coal feed rate.

\section{Exhibit 2.2-23}

\section{Sensor Temperature} Comparison

This plot shows the temperature at one furnace location and for one outer brick surface (the other sensors were not available for this test). There is a significant drop in the furnace bottom temperature which is probably due to the buildup of slag on the sensor tip.
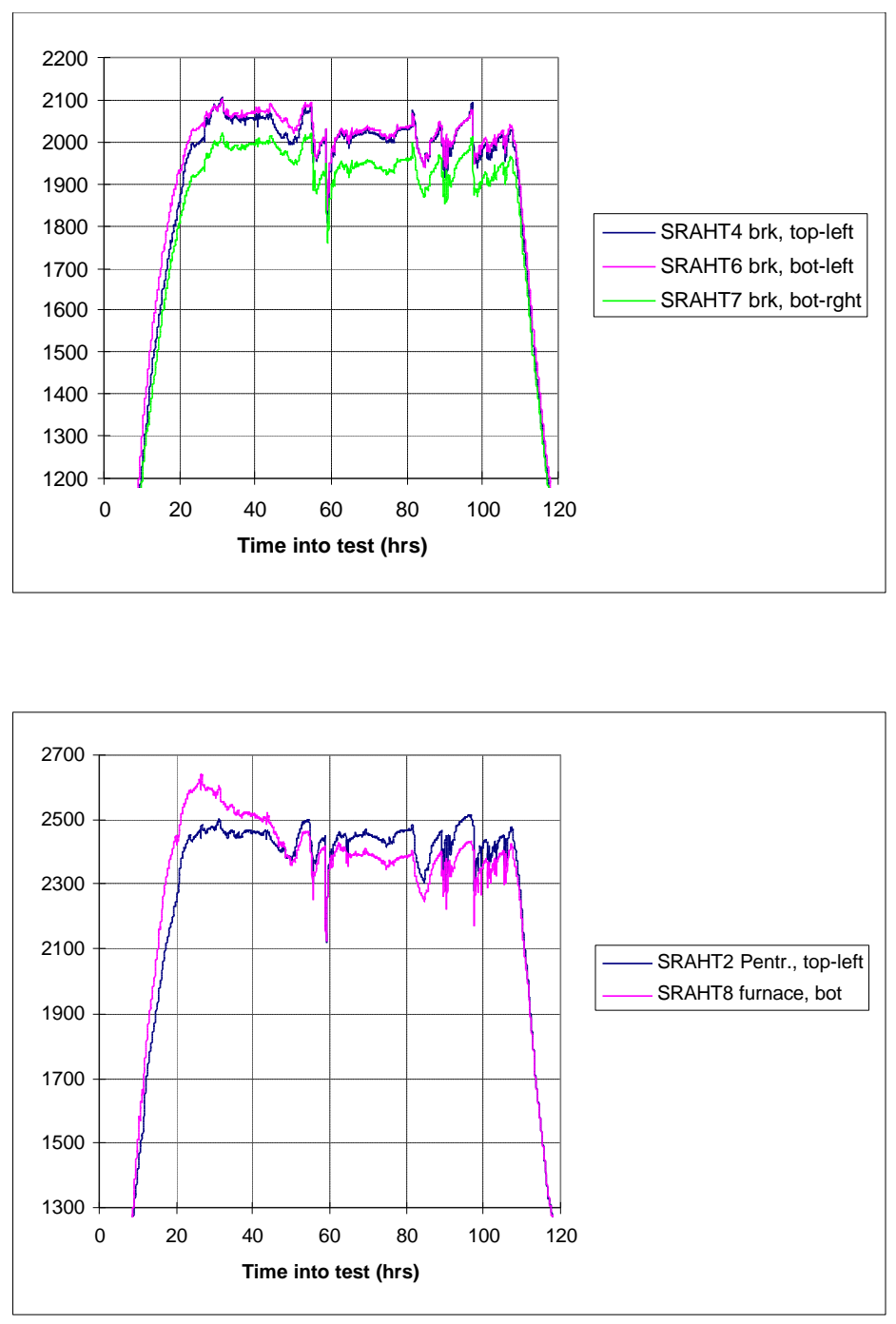


\section{Exhibit 2.2-24 \\ Cooling Water \\ Temperature Increase}

This plot shows the rise in cooling water temperature for each side (cavity) of the small RAH. The nominal flow rate was 3 gpm per side.

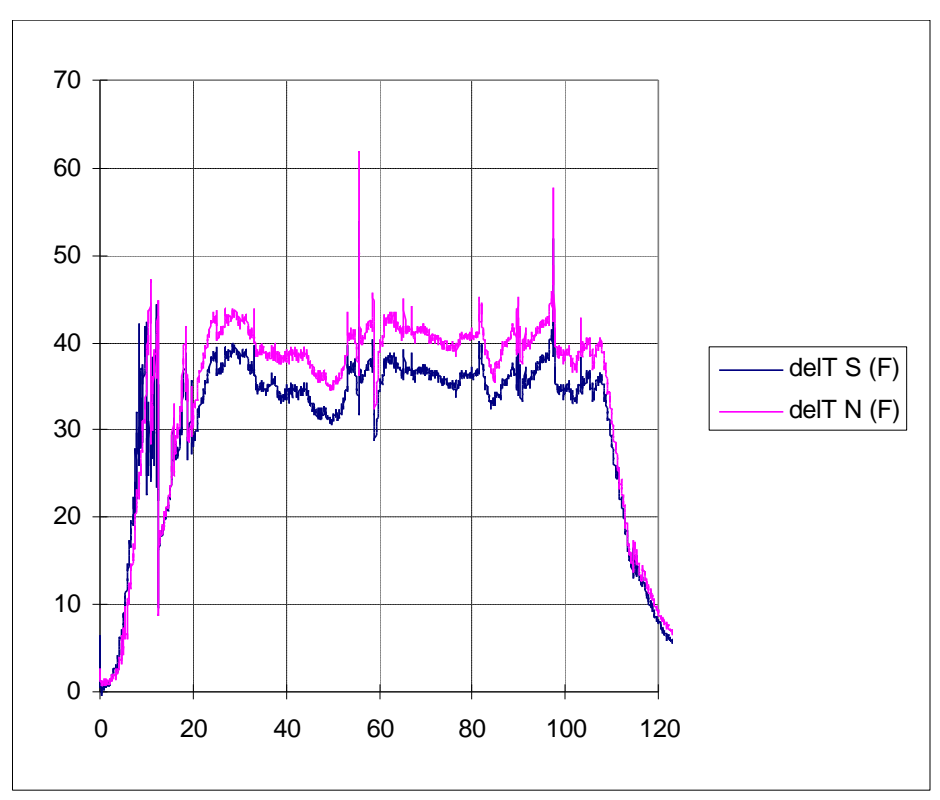

Through most of the test the water flow was maintained at $\sim 3 \mathrm{gpm}$ for each circuit. This equates to a total heat flux of:

$(6 \mathrm{gal} / \mathrm{min}) *(8 \mathrm{\#} / \mathrm{gal}) *(60 \mathrm{~min} / \mathrm{hr}) *(1 \mathrm{btu} / \#-\mathrm{F}) *(\sim 38 \mathrm{~F})=109,000 \mathrm{btu} / \mathrm{hr}[115,900$ $\mathrm{kJ} / \mathrm{hr}]$.

This is slightly higher than the April test, which is consistent with the higher brick temperatures observed.

\section{General Discussion}

For both tests, there was greater heat flux through the South side than through the North side of the SRAH. This can be explained by the fact that the cavities are not the same width; the South is 5.5 inches $[140 \mathrm{~mm}]$ wide, and the North is 6.5 inches $[165 \mathrm{~mm}]$. This difference is consistent with the difference in cooling water temperature increase seen in Exhibits 2.2-21 and 2.2-24 above.

The bricks in the small RAH were not all the same material.

\begin{tabular}{|l|l|c|}
\hline Location & Material & Cold-Side High Emissivity Coating? \\
\hline Top-Left (South) & Monofrax M & Yes \\
\hline Top-Right (North) & Monofrax L & No \\
\hline Bottom-Left (South) & Monofrax L & No \\
\hline Bottom-Right (North) & Monofrax M & No \\
\hline
\end{tabular}




\section{Exhibit 2.2-25}

\section{Back Surface Temperature} Difference - April Test

The brick with consistently the coldest back surface temperature was the Monofrax $\mathrm{M}$ on the bottom right (SRAHT7). This plot shows the temperature difference for the other three bricks using SRAHT7 as the reference.

\section{Exhibit 2.2-26 Back Surface Temperature Difference - June Test}

This is the same plot as Exhibit 2.2-25 except for the June test (Sensor T5 for the top-right brick was not operational).

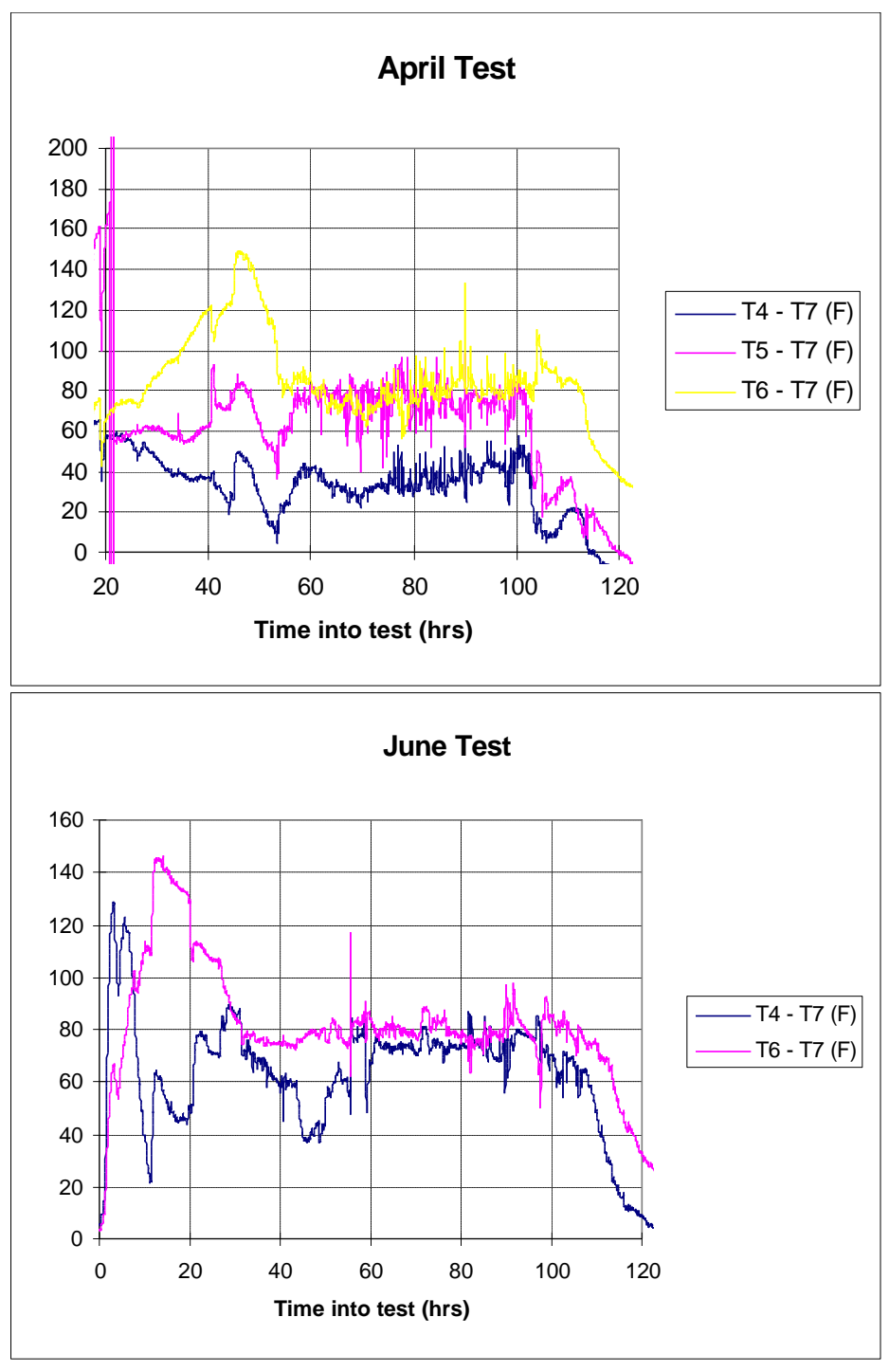

Even after accounting for the fact that the right side should be slightly colder (due to the difference in cavity widths mentioned above) this data still indicates that the Monofrax $M$ (without back coating) had the highest effective thermal resistance, although the difference is small. This conclusion, however, differs from the thermal conductivity data previously obtained for Monofrax M and L. However, it is possible that other secondary factors which are being investigated are influencing this conclusion.

\section{Pilot-Scale Testing}

EERC activities this past quarter involved Design and Procurement, Construction and Shakedown, and HITAF Testing. Final design is complete for all major system components. Other design and procurement activities have been limited to miscellaneous component and equipment items required to improve the performance of the slag tap, slag screen, and system fans; support installation and initial testing of the SRAH panel; improve temperature measurement in the slagging furnace; and reduce SFS process noise. The design and procurement of miscellaneous 
component and equipment items are expected to continue through August in support of the installation of two optical pyrometers to improve slagging furnace temperature measurement and the installation of five mufflers to reduce SFS process noise.

The small radiant air heater (SRAH) panel was installed, and 2 weeks of lignite-fired slagging furnace system (SFS) operation were completed this past quarter. Installation of the SRAH panel occurred in early April prior to the first lignite-fired test period.

The lignite-fired tests were in support of the UTRC effort, but were funded by the North Dakota Industrial Commission (NDIC) and the U.S. Department of Energy Federal Energy Technology Center (DOE FETC) under Contract Number DE-FC21-93MC30098. The purpose of the NDIC-FETC-funded work was to evaluate the SRAH and large radiant air heater (LRAH) panels while firing lignite in the SFS at $100 \%$ load. The lignite tests were performed for comparison with data resulting from previous and future bituminous and subbituminous coal-fired periods. The overall effort also involved trace element sampling at the inlet and outlet of the baghouse for comparison with data from other pilot- and full-scale systems firing similar fuels, bench-scale testing of lignite slag corrosion of monolithic alumina refractory, and laboratory tests of methods for modifying lignite slag viscosity. The first week of operation involved firing Coal Creek-Falkirk lignite (April 19-24), and the second week involved firing Center lignite (June 712). Results from the lignite-fired tests completed in April and June will be compared with bituminous and subbituminous coal test data and summarized in a separate project report for NDIC and FETC. Some of the SFS data and observations concerning the lignite-fired test periods are documented in this report for informational purposes.

The remainder of this section discusses system modifications, and observations and results from the 2 weeks of SFS operation completed this past quarter.

\section{Pilot-Scale Slagging Furnace System}

Exhibit 2.2-27 is a simplified illustration of the overall slagging furnace system. Equipment procurement activities this past quarter included:

- equipment and miscellaneous items (pipe, tubing, fittings, valves, and thermocouple wire) necessary to support the installation of the SRAH panel;

- water-cooled radiators on the forced-draft (FD) and induced-draft (ID) fans;

- two water-cooled process heat exchangers;

- $\quad$ slag pot sight ports; and

- a sootblowing port near the inlet tube sheet of the secondary combustion air preheaters. 


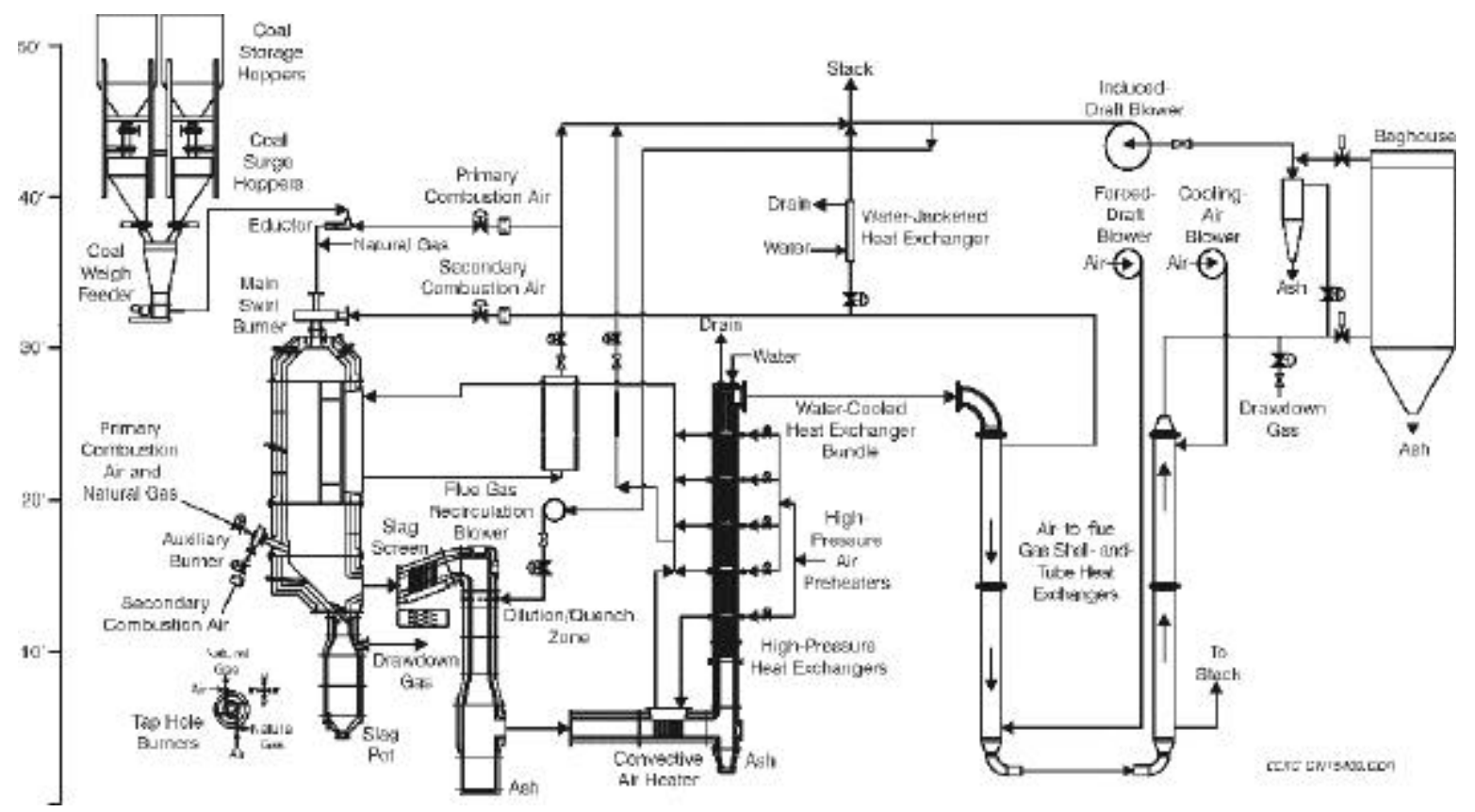

Exhibit 2.2-27

Combustion 2000 Slagging furnace and Support Systems

The focus of electrical work this past quarter included relocating two short conduit runs to reduce exposure to heat and miscellaneous activities in support of overall system operation.

Acquisition of optical pyrometers for furnace temperature measurement is necessary to improve temperature measurement reliability. Temperature measurement in the slagging furnace has been accomplished using Type $\mathrm{S}$ thermocouples. However, thermocouple deterioration has led to subsequent failure. To improve the reliability of furnace temperature measurement and reduce operating cost, the EERC has elected to rent two optical pyrometers for use during the next test period planned for August. The performance of the optical pyrometers will be evaluated at multiple locations and compared with the Type $S$ thermocouples. If the optical pyrometers meet expectations, the EERC will purchase them with the rental fee being applied to the purchase price.

Based on SFS operating experience since installing the LRAH panel in December 1997, EERC personnel have determined that the installation of a few mufflers was necessary to reduce SFS process noise. The primary sources of noise are the system fans and the backpressure cooling airflow control valves supporting the operation of the LRAH panel. Two mufflers were ordered in late June for the outlets of the two backpressure cooling airflow control valves. Three additional mufflers were ordered for the exits of the ID, FD, and cooling air (CA) fans. All five mufflers will be installed and evaluated before the next SFS test period.

In June, the EERC installed liners in five expansion joints in the SFS piping. Installation of the liners was an attempt to reduce SFS process noise. Subsequent testing indicated that three of the liners reduced process noise a few decibels in the immediate vicinity of the expansion joints. Liners added to two expansion joints in the discharge line of the compressed CA system had no effect on noise. 
The modifications, changes, and additions made in May to the SFS to reduce the load on system fans and the overall heat load in the building in which the SFS is located were mostly successful. The ambient temperature near the ceiling of the building was reduced from typically $140^{\circ} \mathrm{F}\left(60^{\circ} \mathrm{C}\right)$ and a maximum of about $150^{\circ} \mathrm{F}\left(66^{\circ} \mathrm{C}\right)$ observed in April to a maximum of $120^{\circ} \mathrm{F}$ $\left(49^{\circ} \mathrm{C}\right)$ with typical values closer to $110^{\circ} \mathrm{F}\left(44^{\circ} \mathrm{C}\right)$ in June. In addition, the heat load on the ID and FD fans was significantly reduced. As a result, the EERC does not expect to encounter any serious operating problems during the summer months.

\section{Fuel Feed System}

Work on the fuel feed system this past quarter involved a few minor modifications as a result of the coal-lignite bridging in the feed hopper that occurred in March and April. Although it is not possible to eliminate coal-lignite feed plugs or bridging in the feed hopper, it is desirable to minimize them for process stability and safety reasons. To mitigate the problem, two air purge nozzles were added in the feed hopper just above the screws. The air purge system includes an air pressure regulator, an adjustable timer, and a solenoid valve. The pressure regulator permits adjustments to the purge pressure, the timer permits adjustments to pulse duration, and the solenoid valve permits operation of the air purge mechanism from the control room.

In addition to the air purge system, an alarm was added to the fuel feed system to inform the process engineer when the screw speed exceeds an upper feed rate limit. Also, when the screw speed exceeds the limit, the controller was programmed to switch from a gravimetric to a volumetric feed mode, minimizing the potential for excessive coal feed rates.

Although lignite feed plugs/bridging were not a problem during the June test period, the air purge system was successfully used during the last day of lignite firing to dislodge a few apparent lignite bridges in the feed hopper. Purge duration was 0.2 seconds at a pulse pressure of 45 psig (3.1 bar). The larger-capacity screws were installed in the screw feeder in May to support the June lignite-fired test period. The larger-capacity screws were necessary to avoid operation of the screw feeder at screw speeds approaching $100 \%$ capacity when firing lignite. During the June lignite test, the screw feeder operated effectively at about $30 \%$ capacity. The smaller screws will be installed in July to support the next test period using Illinois No. 6 bituminous coal.

Mechanical seals associated with the screw feeder were replaced in May because of pulverized lignite leaks observed during the test period in April. EERC personnel are uncertain at this time how frequently seal replacement will be necessary. No other fuel feed system changes or modifications are expected. In general, the performance of the fuel feed system while firing bituminous and subbituminous coal has been quite good since the new screws were obtained in November 1997. Lignite firing in June was also generally problem-free following the minor modifications made in May.

\section{Slagging Furnace}

The pilot-scale slagging furnace design is intended to be as fuel-flexible as possible, with maximum furnace exit temperatures of $2700^{\circ}$ to $2900^{\circ} \mathrm{F}\left(1483^{\circ}\right.$ to $\left.1593^{\circ} \mathrm{C}\right)$ to maintain the desired slag flow. It has a nominal firing rate of $2.5 \mathrm{MMBtu} / \mathrm{hr}\left(2.6 \times 10^{6} \mathrm{~kJ} / \mathrm{hr}\right)$ and a range of 2.0 to $3.0 \mathrm{MMBtu} / \mathrm{hr}\left(2.1\right.$ to $\left.3.2 \times 10^{6} \mathrm{~kJ} / \mathrm{hr}\right)$ using a single burner. The design is based on a bituminous coal (Illinois No. $6-11,100 \mathrm{Btu} / \mathrm{lb}$ or $25,800 \mathrm{~kJ} / \mathrm{kg}$ ) and a nominal furnace residence 
time of $3.5 \mathrm{~s}$. Resulting flue gas flow rates range from roughly 425 to $640 \mathrm{scfm}$ (12 to $18 \mathrm{~m}^{3} / \mathrm{min}$ ), with a nominal value of $530 \mathrm{scfm}\left(15 \mathrm{~m}^{3} / \mathrm{min}\right)$ based on $20 \%$ excess air.

Firing a subbituminous coal or lignite increases the flue gas volume, decreasing residence time to roughly $2.6 \mathrm{~s}$. However, the high volatility of the low-rank fuels results in high combustion efficiency (>99\%). The EERC oriented the furnace vertically (downfired) and based the burner design on a swirl burner currently used on two EERC pilot-scale pulverized coal (pc)-fired units that are fired at $600,000 \mathrm{Btu} / \mathrm{hr}(633,000 \mathrm{~kJ} / \mathrm{hr})$. Slagging furnace dimensions are $47 \mathrm{in} .(119 \mathrm{~cm})$ inside diameter (i.d.) by roughly $18 \mathrm{ft}(5.5 \mathrm{~m}$ ) in length. Exhibit 2.2-28 summarizes volumetric flow rate and temperature data upon which the furnace design was based.

The vertically oriented furnace shell was designed to include four distinct furnace sections. The top section of the furnace supports the main burner connection while the upper-middle furnace section provides a location for installation of the RAH panels. The lower-middle furnace section supports the auxiliary gas burner; the bottom section of the furnace includes the furnace exit to the slag screen as well as the slag tap opening.

Flue gas temperature measurements have been made using four Type $S$ thermocouples protruding $<1$ in. $(<2.5 \mathrm{~cm})$ into the furnace through the refractory wall. Furnace temperature is also measured using thermocouples located at the interface between the high-density and intermediate refractory layers, as well as between the intermediate and insulating refractory layers. A pressure transmitter and gauges are used to monitor static pressures in order to monitor furnace performance. These data (temperatures and pressure) are automatically logged into the data acquisition system and recorded manually on data sheets on a periodic basis as backup. 


\section{Exhibit 2.2-28 \\ Flow and Heat-Transfer Calculations for Combustion 2000 Slagging Furnace and Refractory Ducts Illinois No. 6 Bituminous}

\begin{tabular}{|c|c|c|c|c|c|c|c|}
\hline Firing Rate: & 2.0 & 2.5 & 3.0 & & 2.0 & 2.5 & 3.0 \\
\hline Furnace & & & & Slag screen inlet & & & \\
\hline Furnace i.d., in. & 47 & 47 & 47 & Gas temp., ${ }^{\circ} \mathrm{F}$ & 2700 & 2750 & 2800 \\
\hline Coal Feed Rate, lb/hr & 179 & 224 & 269 & Flue gas flow rate, acfm & 3245 & 3695 & 4089 \\
\hline Airflow Rate, scfm & 394 & 493 & 591 & Gas velocity, $\mathrm{ft} / \mathrm{s}$ & 60.6 & 69.0 & 76.2 \\
\hline Flue Gas Flow Rate, scfm & 425 & 531 & 638 & & & & \\
\hline Flue Gas Flow Rate, acfm & 2665 & 3408 & 4181 & Dilution gas requirements & & & \\
\hline Furnace Gas Velocity, $\mathrm{ft} / \mathrm{s}$ & 3.7 & 4.7 & 5.8 & Gas velocity in, $\mathrm{ft} / \mathrm{s}$ & 58.7 & 66.8 & 73.9 \\
\hline Exit Gas Velocity, ft/s & 30.3 & 34.5 & 38.1 & Exit gas temp., ${ }^{\circ} \mathrm{F}$ & 1865 & 1865 & 1865 \\
\hline \multirow{2}{*}{ Flue Gas Residence Time, s } & 4.1 & 3.2 & 2.6 & Dilution gas temp., ${ }^{\circ} \mathrm{F}$ & 300 & 300 & 300 \\
\hline & & & & Calc. dilution gas, scfm & 275 & 329 & 380 \\
\hline Auxiliary Burner, MMBtu/hr & 0.666 & 0.426 & 0.122 & Total flue gas flow, scfm & 815 & 934 & 1039 \\
\hline Wall Losses, MMBtu/hr & 0.196 & 0.203 & 0.212 & Flue gas flow rate out, acfm & 3643 & 4176 & 4646 \\
\hline Other Losses, MMBtu/hr & 0.090 & 0.090 & 0.090 & Gas velocity out, $\mathrm{ft} / \mathrm{s}$ & 66.0 & 75.5 & 84.0 \\
\hline Furnace Sect. Length, $\mathrm{ft}$ & 16 & 16 & 16 & Dilution gas nozzles & & & \\
\hline Refract. 1 Thickness, in. & 4 & 4 & 4 & Nozzle diameter, in. & 1.25 & 1.25 & 1.25 \\
\hline Refract. 2 Thickness, in. & 4 & 4 & 4 & No. of nozzles & 8 & 8 & 8 \\
\hline Refract. 3 Thickness, in. & 3.25 & 3.25 & 3.25 & Dilution gas flow, acfm & 402 & 480 & 556 \\
\hline Furnace Weight, tons & 14.4 & 14.4 & 14.4 & Dilution gas velocity, $\mathrm{ft} / \mathrm{s}$ & 98 & 117 & 136 \\
\hline Inlet Gas Temp., ${ }^{\circ} \mathrm{F}$ & 2900 & 3000 & 3100 & Convective air heater & & & \\
\hline Avg. Gas Temp., ${ }^{\circ} \mathrm{F}$ & 2800 & 2875 & 2950 & Gas temp., ${ }^{\circ} \mathrm{F}$ & 1800 & 1800 & 1800 \\
\hline Exit Gas Temp., ${ }^{\circ} \mathrm{F}$ & 2700 & 2750 & 2800 & Flue gas flow rate, acfm & 3545 & 4059 & 4515 \\
\hline Refract. 1 Surf. Temp., ${ }^{\circ} \mathrm{F}$ & 2677 & 2752 & 2828 & Gas velocity, $\mathrm{ft} / \mathrm{s}$ & 57.3 & 65.5 & 72.9 \\
\hline Refract. 2 Surf. Temp., ${ }^{\circ} \mathrm{F}$ & 2431 & 2498 & 2567 & & & & \\
\hline Refract. 3 Surf. Temp., ${ }^{\circ} \mathrm{F}$ & 1751 & 1799 & 1848 & & & & \\
\hline Furnace Skin Temp., ${ }^{\circ} \mathrm{F}$ & 275 & 280 & 286 & & & & \\
\hline Assumption: Exces & & & & & & & \\
\hline
\end{tabular}

Observation ports are located in the furnace to permit visual observation of the main burner flame, auxiliary burner flame, RAH panels, slag screen, and slag tap. During this past quarter, one sight port was added to each of the four sections of the slag pot to permit observation of slag buildup and determine when to break up stalagmitelike deposits to make better use of the available volume in the slag pot.

The slag tap was intended to be as simple and functional as possible. To that end, the original design was a simple refractory-lined hole in the bottom of the furnace. The diameter of the slag tap was 6 in. $(15 \mathrm{~cm})$, with the potential to change the diameter by simply removing or repouring 
refractory. To minimize heat losses, slag is collected in an uncooled, dry container with refractory walls. Because of plugging problems experienced in September and October 1997, the slag tap refractory was replaced, reducing the diameter of the hole to nominally 5 in. $(13 \mathrm{~cm})$ and creating a well-defined drip edge. In addition, a multiport tap burner was added early in 1998. As a result, although some slag tap deposits do form, no slag tap plugging was encountered during the SFS operating periods completed in February (Illinois No. 6 bituminous coal), March (Rochelle subbituminous coal), and April (Coal Creek-Falkirk lignite). In June (Center lignite), the slag tap did plug once likely due to the severe erosion of the entire slag tap. This plug was removed online after switching to natural gas firing.

The refractory walls in the slagging furnace consist of three castable refractory layers:

- 4 in. $(10.2 \mathrm{~cm})$ of high-density (14 Btu-in./ft ${ }^{20} \mathrm{~F}-\mathrm{hr}$ or $\left.2.0 \mathrm{~W} / \mathrm{m}-\mathrm{K}\right)$ slag-resistant material,

- 4 in. $(10.2 \mathrm{~cm})$ of an intermediate refractory (4.0 Btu-in. $/ \mathrm{ft}^{2}-{ }^{\circ} \mathrm{F}-\mathrm{hr}$ or $\left.0.6 \mathrm{~W} / \mathrm{m}-\mathrm{K}\right)$, and

- 3.25 in. $(8.3 \mathrm{~cm})$ of a low-density insulating refractory $\left(1.3 \mathrm{Btu}-\mathrm{in} . / \mathrm{ft}^{2}-{ }^{\circ} \mathrm{F}-\mathrm{hr}\right.$ or $\left.0.2 \mathrm{~W} / \mathrm{m}-\mathrm{K}\right)$.

Three refractory layers were selected as a cost-effective approach to reduce the overall size and weight of the system. Because of its greater structural strength and high corrosion resistance, Plibrico Plicast Cement-Free 98V alumina castable was originally used in the top three furnace sections, in the exit of the furnace, and in the top section of the dilution/quench zone. Plicast Cement-Free $99 \mathrm{~V}$ was used in the bottom furnace section (except for the exit), slag tap, slag screen, and transition to the dilution/quench zone because of its even greater resistance to slag attack.

After several weeks of furnace operation, refractory repairs were made to the high-density refractory in the top section of the furnace and the upper-middle furnace section. In the top section of the furnace, the Plibrico Plicast Cement-Free 98V refractory was replaced with a Narco Cast 60 castable refractory. Replacement was necessary because of the shrinkage experienced by the Plibrico Plicast Cement-Free 98V. The Narco Cast 60 refractory was selected as a replacement because of past success with its use in other furnace systems and because it would not shrink like the Plibrico Plicast Cement-Free 98V. Although the Narco Cast 60 is much more prone to slag corrosion, operating experience has shown that slag deposition is not significant in the top section of the furnace. After 5 weeks of operation, the Narco Cast 60 refractory appears to be in good shape. However, some refractory deterioration was evident in the top section of the furnace after 2 weeks of lignite firing.

In conjunction with the installation of the SRAH panel, refractory repairs were made in the upper-middle furnace section. Repairs involved replacing sections of the high-density refractory (Plibrico Plicast Cement-Free 98V) in the vicinity of the RAH panel door frames. The repairs were necessary because of the combination of refractory shrinkage that occurred upon initial curing, some refractory deterioration as a result of furnace operation, and the removal of the temporary door to permit installation of the SRAH panel.

The upper middle section of the furnace showed more severe refractory damage as a result of lignite firing. Some patching of the high-density refractory in the upper middle furnace section was necessary after the test periods completed in April and June, especially where the refractory was itself a fresh patch. EERC personnel believe that the newly repaired/patched portions of the 
refractory corroded excessively because it was not fired to as high a temperature before beginning coal-lignite feed as the older refractory had been during the original system shakedown.

As part of the August test period, the EERC will attempt to cure the new refractory at $2900^{\circ}$ to $3000^{\circ} \mathrm{F}$ in order to improve its corrosion resistance. Complete replacement of the high-density furnace refractory was anticipated in the original Combustion 2000 scope of work. However, the extent and timing of high-density refractory replacement is uncertain at this time. EERC personnel plan to give serious consideration to replacing the high-density refractory in the furnace after the August test period. Exhibit 2.2-29 summarizes refractory properties. 


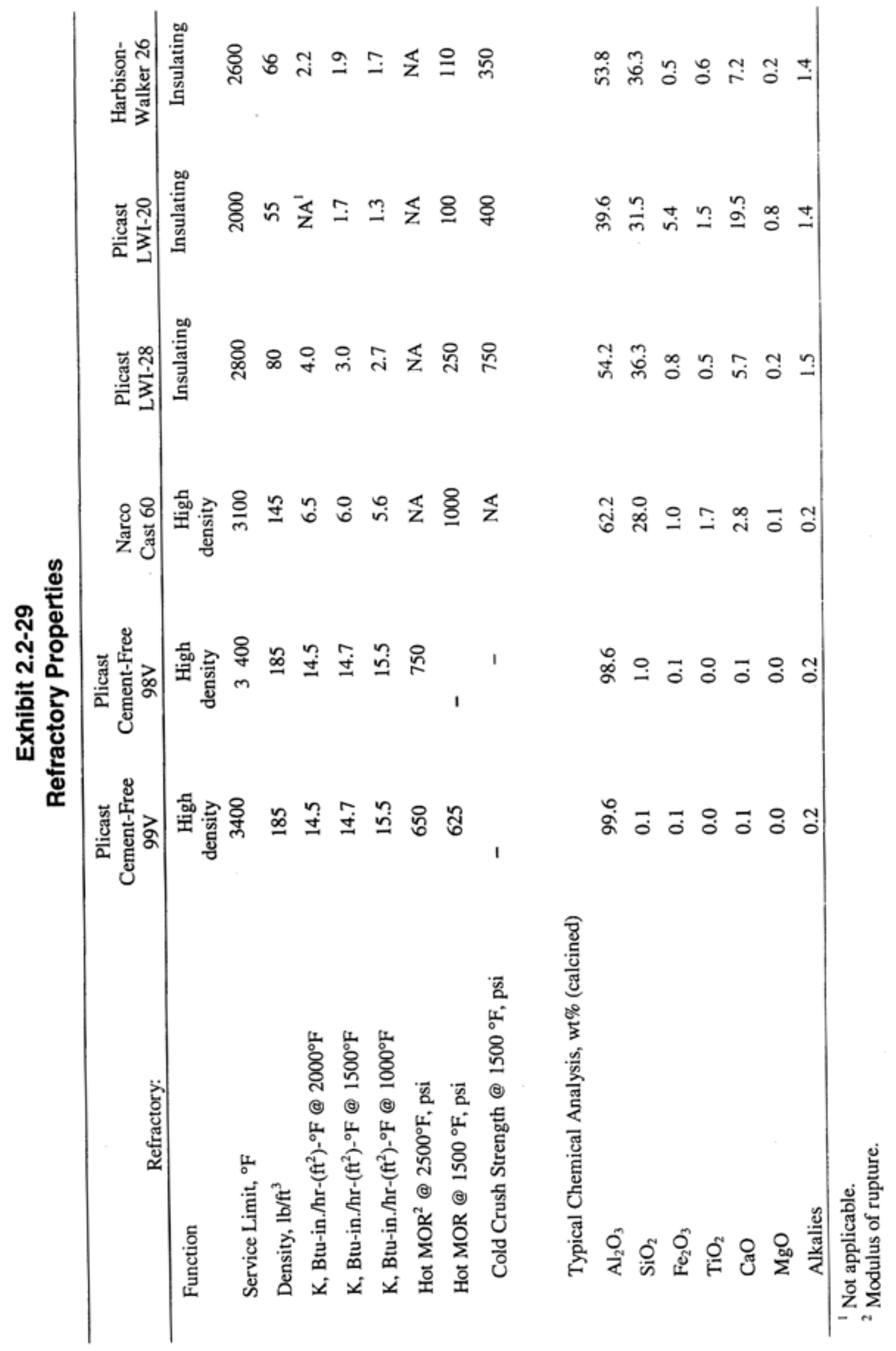




\section{Main and Auxiliary Burners}

The main burner is natural gas- and pulverized fuel-capable. The basic design is an International Flame Research Foundation (IFRF)-type adjustable secondary air swirl generator which uses primary and secondary air at approximately $15 \%$ and $85 \%$ of the total air, respectively, to adjust swirl. Increasing swirl to provide flame stability and increased carbon conversion can also affect the formation of $\mathrm{NO}_{\mathrm{x}}$. Carbon efficiency has been $>99 \%$ in the slagging furnace when bituminous and subbituminous coal and lignite are fired. High carbon efficiencies can be obtained in the slagging furnace at relatively low swirl settings because of the high operating temperature. Combustion air flow rates through the main burner range from about 400 to $600 \mathrm{scfm}$ (11 to $17 \mathrm{~m}^{3} / \mathrm{min}$ ), depending on furnace firing rate and the fuel type (bituminous, subbituminous, or lignite) fired.

An auxiliary gas burner $(850,000 \mathrm{Btu} / \mathrm{hr}$ or $896,750 \mathrm{~kJ} / \mathrm{hr})$ is located near the furnace exit in order to control furnace exit temperature, ensuring desired slag flow from the furnace and the slag screen. This auxiliary burner is used to compensate for heat losses through the furnace walls, sight ports, and RAH test panels. The use of the auxiliary gas burner is beneficial during start-up to reduce heatup time and to prevent the freezing of slag on the slag screen when the switch is initially made to coal firing.

\section{Radiant Air Heater Panels}

A key design feature of the furnace is accessibility for installation and testing of one LRAH panel and one SRAH panel. The furnace design will accept one LRAH panel with a maximum active size of $1.5 \times 6.4 \mathrm{ft}(0.46 \times 1.96 \mathrm{~m})$. This size was selected to minimize furnace heat losses and was based on panel-manufacturing constraints identified by UTRC. Flame impingement on the RAH panels is not necessarily a problem. Cooling air for the LRAH panel is provided by an existing EERC air compressor system having a maximum delivery rate of $510 \mathrm{scfm}\left(14.4 \mathrm{~m}^{3} / \mathrm{min}\right)$ and a maximum stable delivery pressure of 275 psig (19 bar). Backup cooling air is available from a smaller compressor at a maximum delivery rate of $300 \mathrm{scfm}(8.5 \mathrm{~m} / \mathrm{min})$ and pressure of $<100$ psig ( $<7$ bar). A tie-in to an existing nitrogen system was also installed as a backup to the existing air compressor system. In the event of a failure of inlet CA piping, a backflow emergency piping system was installed so that overheating of the LRAH panel could be avoided. UTRC designed and fabricated the RAH test panels. The LRAH test panel arrived at the EERC on September 15, 1997. Final assembly and installation of the LRAH panel into the furnace occurred in November 1997.

Furnace design also permits the installation of a nominally sized $1.5-\times 5.4-\mathrm{ft}(0.46-\times 1.65-$ m) RAH panel. The purpose of the SRAH panel is to expose ceramic materials to slagging furnace conditions rather than generating heat-transfer data. A primary difference between the LRAH and SRAH panels is that the SRAH panel is cooled with water rather than heated air. The SRAH panel is water-cooled using two sets of five vertically oriented 0.375 -in. $(0.952-\mathrm{cm})$ outside diameter (OD) stainless steel tubes. While the SRAH panel is $1 \mathrm{ft}(0.3 \mathrm{~m})$ shorter than the LRAH panel, both assemblies are the same width and use the same air-cooled frame support design. A central vertical ceramic rail is present in the SRAH panel, allowing the installation of either full-width $(18$-in./46-cm)or half-width panels inside the furnace. The SRAH panel was delivered the first week of April and installed prior to the weeklong lignite test period completed for April 19-24. 
Exhibit 2.2-30 presents photographs of the completed SRAH panel assembly from both the exterior and interior of the furnace. The photograph of the furnace interior on the right shows the new SRAH ceramic tiles/bricks on the right, new refractory above and between the RAH panels, and the LRAH panel on the left. The SRAH panel was installed and two damaged tiles were replaced in the LRAH panel in April prior to the first lignite-fired test period. Shakedown and initial testing of the SRAH panel were completed this past quarter. 

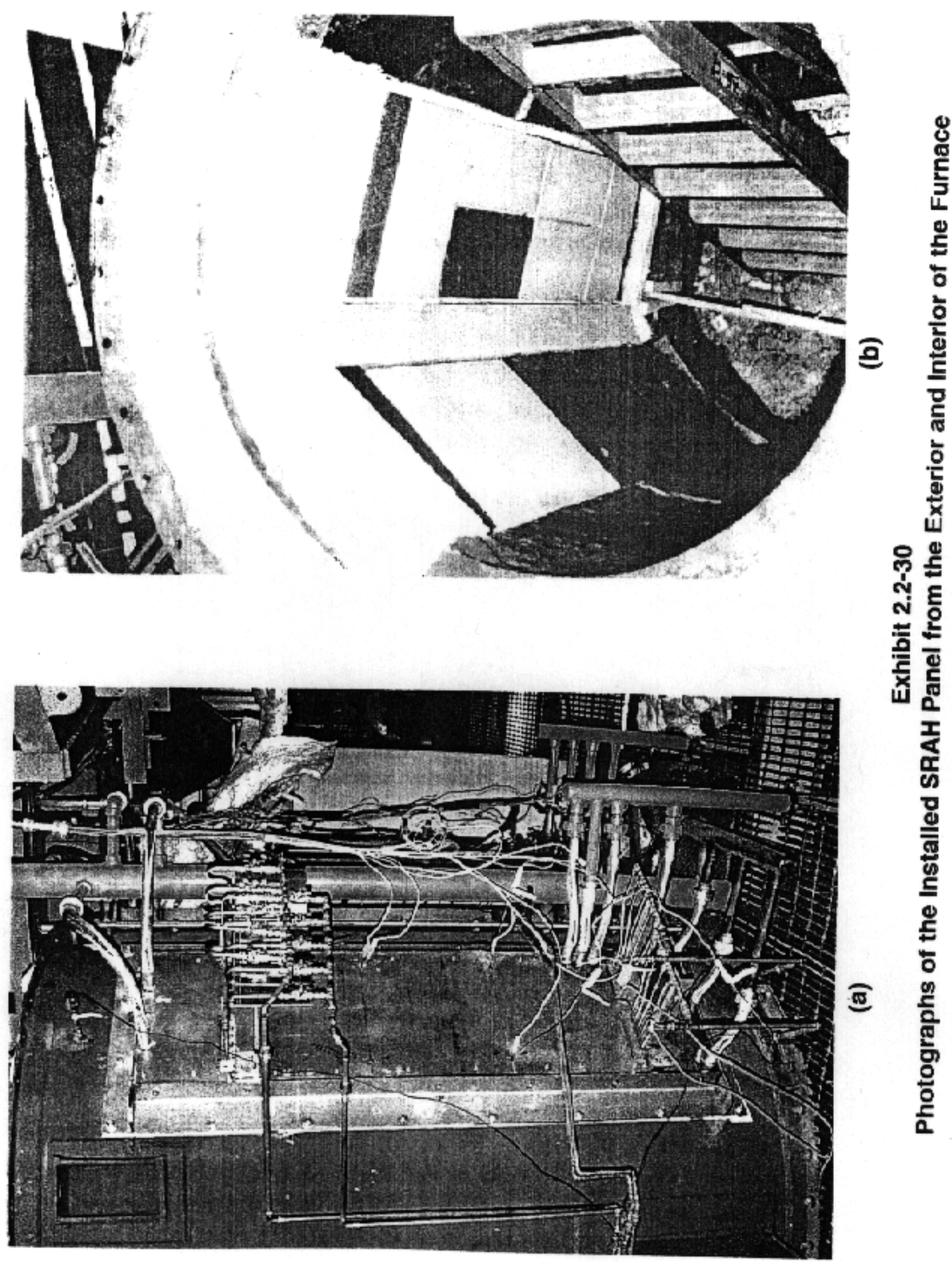


\section{Slag Screen}

The slag screen design for the pilot-scale slagging furnace system is the result of a cooperative effort between the EERC, UTRC, and Physical Sciences Inc. (PSI) personnel. The primary objective for the pilot-scale slag screen is to reduce the concentration of ash particles entering the $\mathrm{CAH}$. Design criteria specific to the pilot-scale slag screen include

1) a simple design permitting modifications if necessary using readily available, inexpensive materials;

2) matching duct dimensions and flue gas flow rates to maintain turbulent flow conditions;

3) minimizing the potential for plugging as the result of slag deposit growth on tube surfaces or the sloped floor;

4) limiting differential pressure across the slag screen to 2 in. W.C. (4 mmHg); and

5) limiting heat losses to assure desired slag flow from the slag screen to the furnace slag tap.

The walls of the slag screen consist of two refractory layers. The inner, high-density layer is a Plicast Cement-Free 98V with an outer insulating layer of Harbison-Walker Castable 26. The high-density refractory is 2.25 -in. $(5.7-\mathrm{cm})$ thick in the sidewalls and 4 in. $(10.2-\mathrm{cm})$ thick in the roof and floor of the slag screen. The insulating refractory is $3.75 \mathrm{in} .(9.5 \mathrm{~cm})$ thick in the sidewalls, roof, and floor. A Plicast LWI-28 refractory was used around the sight ports in the wall of the slag screen. Properties for the high-density and insulating refractories selected for use in the slag screen are summarized in Exhibit 2.2-29.

Water-cooled surfaces were placed inside of the refractory tubes to cool the tubes and reduce the erosion/corrosion observed during shakedown tests. Specific details concerning slag screen modifications and performance this past quarter are addressed later in this report.

\section{Dilution/Quench Zone}

The dilution/quench zone design was a cooperative effort between the EERC and UTRC. The circular dilution/quench zone is oriented vertically, maintains a $1.17-\mathrm{ft}(0.36-\mathrm{m})$ diameter in the area of the flue gas recirculation nozzles, and then expands the duct diameter to $2 \mathrm{ft}(0.6 \mathrm{~m})$ to provide adequate residence time within duct length constraints. The duct section containing the flue gas recirculation nozzles is a spool piece in order to accommodate potential changes to the size, number, and orientation of the flue gas recirculation nozzles. The vertically oriented dilution/quench zone is refractory-lined and located immediately downstream of the slag screen and upstream of the $\mathrm{CAH}$ duct.

Routine cleaning of the dilution/quench zone has been required during each weeklong bituminous/subbituminous coal and lignite test period. To better monitor and document the slag deposition in the dilution/quench zone, a differential pressure transmitter was purchased and installed prior to the lignite-fired tests.

\section{Convective Air Heater}

The CAH design was a cooperative effort between the EERC and UTRC. It was constructed by UTRC and installed in September 1997. The flue gas flow rate to the CAH tube bank has been calculated to range from 3553 to 4619 acfm at $1800^{\circ} \mathrm{F}\left(101\right.$ to $131 \mathrm{~m}^{3} / \mathrm{min}$ at $\left.982^{\circ} \mathrm{C}\right)$. A rectangular inside duct dimension of $1.17 \mathrm{ft}^{2}\left(0.11 \mathrm{~m}^{2}\right)$ results in a flue gas approach velocity of 
50 to $73 \mathrm{ft} / \mathrm{s}$ (15 to $22 \mathrm{~m} / \mathrm{s})$ to the CAH. The CAH consists of twelve 2-in. (5-cm)-diameter tubes installed in a staggered three-row array. The first five tubes in the flue gas path were originally uncooled ceramic material, with the remaining seven tubes cooled using heated air. The uncooled ceramic tubes were replaced in May with uncooled stainless steel tubes. Replacement of the ceramic tubes was necessary because the ceramic tubes were repeatedly damaged when the tube bank was removed from the duct after the test periods in February, March, and April. Heat is recovered from the flue gas to meet $\mathrm{CA}$ temperature requirements for the $\mathrm{CAH}$. The design $\mathrm{CA}$ exit temperature from the $\mathrm{CAH}$ is $1200^{\circ} \mathrm{F}\left(649^{\circ} \mathrm{C}\right)$ and is not permitted to exceed $1300^{\circ} \mathrm{F}$ $\left(705^{\circ} \mathrm{C}\right)$. CA flow rate is used to control CA exit temperature using a flow control valve.

\section{System Fans}

The pilot-scale SFS has five fans, a combustion air FD fan, two CA FD fans, an ID fan, and a flue gas recirculation (FGR) fan. Exhibit 2.2-31 summarizes the fan specifications. All five are centrifugal-type fans, with variable-speed drives (speed controllers) installed on the four large fans. Valves and orifice plates and venturis are used to control and measure, respectively, the air and flue gas flow in the SFS. The small FD fan provides cooling air to the RAH panel door frames. Each RAH door frame requires $100 \mathrm{scfm}\left(2.8 \mathrm{~m}^{3} / \mathrm{min}\right)$ of cooling air. Two valves and flow measurement devices were installed to permit measurement and control of CA flow rates to each of the RAH door frames. Final piping connections for cooling the SRAH panel door frame were made in April.

Two water-cooled heat exchangers were fabricated and installed in May to reduce the load on the FD, ID, and CA fans and ambient temperature on the upper levels of the SFS support structure. A water-cooled heat exchange tube bundle was installed in the flue gas stream between the five existing high-pressure CA preheater tube bundles and the first tube-and-shell heat exchanger. This water-cooled tube bundle reduces the cooling load on the FD and CA fans. Air from the FD fan is preheated in the first two tube-and-shell heat exchangers and cools the flue gas. The extra air required for flue gas cooling, but not required as secondary air for the primary burner, is bypassed to the stack. A water-jacketed heat exchanger was installed on the bypass line to reduce the amount of heat being emitted to the immediate area. In addition, insulation was added to several piping surfaces to help reduce ambient temperature in the structure during SFS operation. 


\section{Exhibit 2.2-31}

\section{Pressure, Temperature, and Flow Specifications for SFS Fans}

\begin{tabular}{|c|c|c|c|c|c|c|c|c|c|}
\hline & $\begin{array}{c}\text { Inlet } \\
\text { Pressure, } \\
\text { psig }\end{array}$ & $\begin{array}{c}\text { Exit } \\
\text { Pressure, } \\
\text { psig }\end{array}$ & $\begin{array}{l}\text { Avg. } \\
\text { Inlet } \\
\text { Temp., } \\
{ }^{\circ} \mathrm{F}\end{array}$ & $\begin{array}{c}\text { Min. } \\
\text { Inlet } \\
\text { Temp., } \\
{ }^{\circ} \mathrm{F}\end{array}$ & $\begin{array}{c}\text { Max. } \\
\text { Inlet } \\
\text { Temp., } \\
{ }^{\circ} \mathrm{F}\end{array}$ & $\begin{array}{c}\text { Max. } \\
\text { Inlet } \\
\text { Flow, } \\
\text { scfm }\end{array}$ & $\begin{array}{c}\text { Max. } \\
\text { Inlet } \\
\text { Flow, } \\
\text { acfm }\end{array}$ & $\begin{array}{l}\text { Avg. } \\
\text { Inlet } \\
\text { Flow, } \\
\text { acfm }\end{array}$ & $\begin{array}{l}\text { Motor } \\
\text { Horse- } \\
\text { power }\end{array}$ \\
\hline FD Fan & & & & & & & & & \\
\hline & 0 & 3 & 60 & 20 & 100 & 1200 & 1292 & 1200 & 40 \\
\hline CA Fan & 0 & 1.5 & 60 & 20 & 100 & 1200 & 1292 & 1200 & 20 \\
\hline ID Fan & 1 & 0.5 & 350 & 250 & 450 & 1200 & 2255 & 1755 & 25 \\
\hline FGR Fan & 0 & 1.5 & 350 & 250 & 450 & 450 & 788 & 701 & 10 \\
\hline CA Fan & 0 & 2.0 & 80 & 60 & 100 & 200 & 200 & 200 & 5 \\
\hline
\end{tabular}

Two FD water-cooled radiators were installed in May on the FD and ID fan motors to protect them from overloading due to the high ambient temperatures on the sixth level of the support structure. The radiators generate cool air that circulates over the electric motors.

\section{Emission Control}

A pulse-jet baghouse is used for final particulate control on the pilot-scale SFS. The baghouse design permits operation at both cold-side $\left(250^{\circ}\right.$ to $400^{\circ} \mathrm{F} / 121^{\circ}$ to $\left.205^{\circ} \mathrm{C}\right)$ and hot-side $\left(600^{\circ}\right.$ to $700^{\circ} \mathrm{F} / 316^{\circ}$ to $371^{\circ} \mathrm{C}$ ) temperatures. The primary baghouse chamber and ash hopper walls are electrically heated and insulated to provide adequate temperature control to minimize heat loss and avoid condensation problems on start-up and shutdown. The main baghouse chamber was designed with internal angle iron supports to handle a negative static pressure of 15 in. W.C. (28 $\mathrm{mmHg}$ ).

Total flue gas flow rate downstream of the baghouse is measured using a venturi. Flue gas sample ports were installed in the inlet and outlet piping of the baghouse to permit flue gas sampling for gaseous/vapor-phase constituents as well as fly ash. Fly ash particle-size distribution and mass loading are determined periodically using standard U.S. Environmental Protection Agency (EPA) methods. Hazardous air pollutant (HAP) measurements can be taken using existing sample ports and EPA Method 29 and the Ontario Hydro method for mercury speciation.

\section{Instrumentation and Data Acquisition}

The instrumentation and data acquisition components for the pilot-scale SFS address combustion air, flue gas, cooling air, cooling water, and other appropriate measurements (temperatures, static and differential pressures, and flow rates). The data acquisition system is based on a Genesis software package and three personal computers. Two sets of flue gas instrumentation (oxygen, carbon dioxide, carbon monoxide, sulfur dioxide, and nitrogen species) are dedicated to support the operation of the SFS. A new heat trace line for flue gas sampling was installed this past quarter as planned. The new heat trace line worked as expected during the 
lignite-fired tests in April and June. The only problem encountered occurred in April when the flue gas sample probe in the slag screen began leaking water, which forced the termination of flue gas sampling at that location near the end of the test period.

Other instrumentation/data acquisition activities this past quarter included installation of thermocouples supporting the SRAH panel, their connection to the data acquisition system, and miscellaneous activities in support of SFS operation. The instrumentation work is complete except for installation of two optical pyrometers for furnace temperature measurement and routine repair and replacement of components as a function of SFS operation.

\section{Pilot-Scale SFS Operation}

The pilot-scale SFS was operated in support of lignite-fired LRAH and SRAH panel tests during the weeks of April 19-24 (Coal Creek-Falkirk lignite) and June 7-12, 1998 (Center lignite). The lignite-fired tests were in support of the UTRC effort, but were funded by NDIC and FETC. The purpose of the NDIC-FETC-funded work was to evaluate the SRAH and LRAH panels while firing lignite in the SFS at $100 \%$ load. The lignite tests were performed for comparison with data resulting from previous and future bituminous and subbituminous coal-fired periods. Results from the lignite-fired tests completed in April and June and comparisons with bituminous and subbituminous coal data will be summarized in a separate project report. SFS operating data and observations concerning the lignite-fired test periods are summarized here.

\section{Fuel Feed System}

The fuel feed system was operated in April (50 hr, Coal Creek-Falkirk lignite) and June (50 $\mathrm{hr}$, Center lignite) at nominal feed rates of 370 to $400 \mathrm{lb} / \mathrm{hr}(168$ to $182 \mathrm{~kg} / \mathrm{hr}$ ) and 345 to 360 $\mathrm{lb} / \mathrm{hr}$ (157 to $163 \mathrm{~kg} / \mathrm{hr}$ ), respectively, in an attempt to maintain a lignite firing rate of 2.5 $\mathrm{MMBtu} / \mathrm{hr}\left(2.6 \times 10^{6} \mathrm{~kJ} / \mathrm{hr}\right)$. Exhibits 2.2-32 and 2.2-33 illustrate the lignite feed rate for the test periods completed in April and June, respectively. In April, the lignite feed rate was affected by high and variable surface moisture that caused bridging in the feed hopper, resulting in the feed instability observed in Exhibit 2.2-32. However, ash deposition and slag tap plugging were not problems during the April test period with the Coal Creek-Falkirk lignite, owing to favorable ash chemistry. 


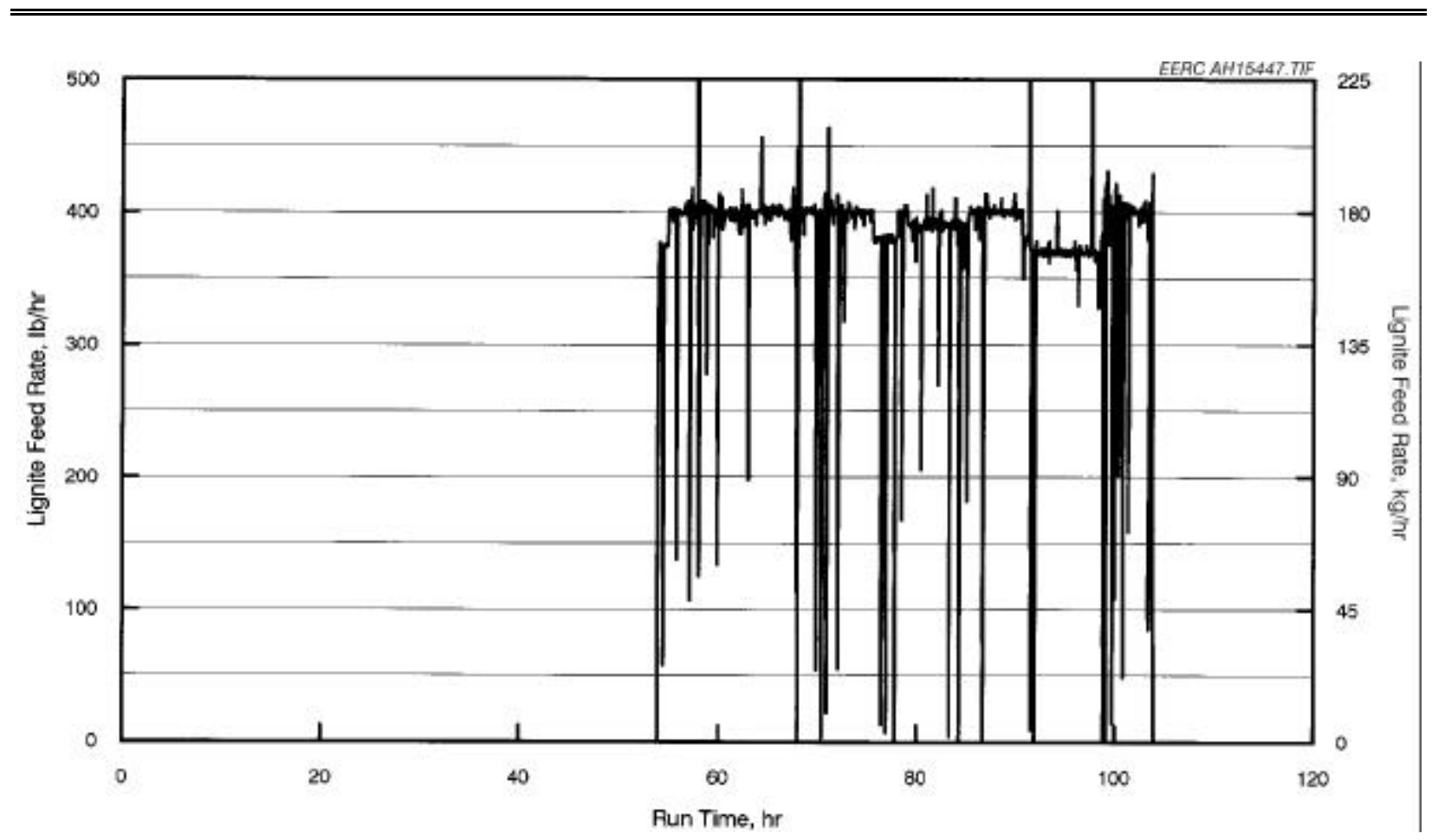

Exhibit 2.2-32

Lignite Feed Rate versus Run Time for the April 1998 Test Period

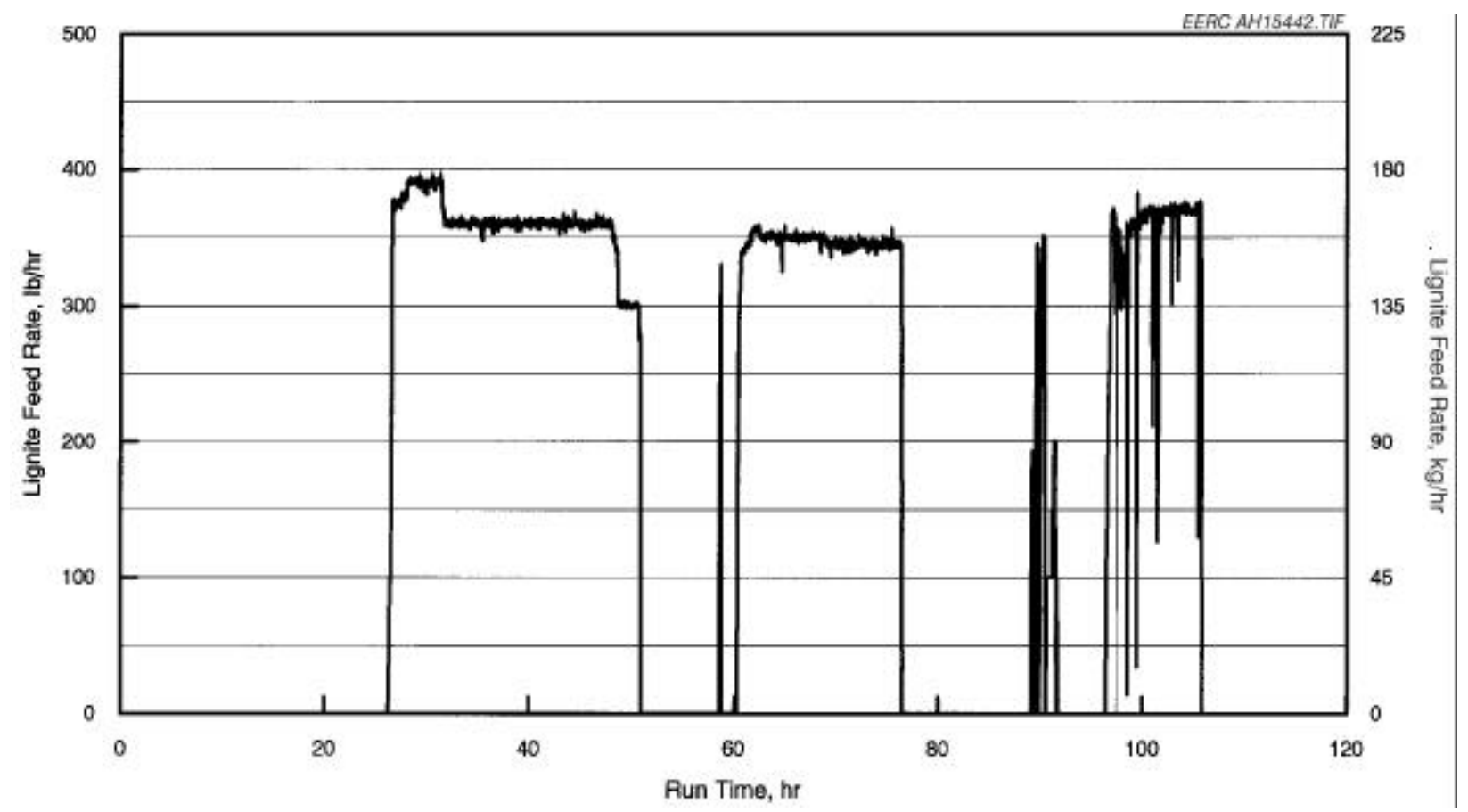

Exhibit 2.2-33

Lignite Feed Rate versus Run Time for the June 1998 Test Period

During the June test period with the Center lignite, the fuel feed rate was much more stable as a result of lower surface moisture. However, the ash chemistry (higher alkali content) resulted in 
deposition and plugging problems in a tube-and-shell heat exchanger at roughly Run Hour 50, forcing a temporary termination of the lignite feed. The main burner was switched to natural gas firing to maintain system temperatures while the ash plugging was remedied.

Lignite feed resumed at about Run Hour 60 and continued for nominally 16 hours until slag plugged off the slag tap. Again, main burner firing was switched to natural gas, and then the slag tap and pot were removed and cleaned. Coal Creek-Falkirk lignite was fired for about nine hours on the last day to permit some of the April mercury-sampling activities to be repeated prior to shutdown. Again, periodic hopper bridging was observed while firing the Coal Creek-Falkirk lignite during this time period. However, these events were easily resolved using the air pulse system installed in May.

During both lignite-fired test periods, adjustments to lignite feed rate were made to simply maintain a lignite firing rate of nominally $2.5 \mathrm{MMBtu} / \mathrm{hr}$ as fuel characteristics changed during the week. The resulting furnace temperature was nominally $2700^{\circ} \mathrm{F}\left(1483^{\circ} \mathrm{C}\right)$.

Although no fire was observed, a couple of plastic thermocouple heads and the infrared (IR) temperature sensor inside the LRAH panel were damaged during the June test. A sooty residue near holes on the exterior cover plates is also evidence that hot flue gas from the furnace escaped through the RAH panels as a result of a pressure surge in the furnace. The duration of the pressure surge is believed to have only been a few minutes $(<5)$, since that is the amount of time it took the ID fan control loop to balance system pressure. EERC personnel observed three pressure surges during the June test period. Two occurred between Run Hours 50 and 60. The first occurred as a result of an on-line piping change to improve the performance of the flue gas recirculation system. The second occurred when the differential pressure on the tube-and-shell heat exchangers quickly jumped to $>20$ in. W.C. $(>37 \mathrm{mmHg})$ as a result of ash deposition and plugging. The third pressure surge occurred early on June 12, when the ID fan tripped several times as a result of very high system flue gas flow rates.

Minor pressure surges (a few inches of W.C.) are not uncommon in the slagging furnace. They happen on a periodic basis as a result of baghouse cleaning, opening access ports to clean the dilution/quench zone and $\mathrm{CAH}$ tube bank, opening of access ports to insert or remove sampling probes, and when altering flue gas flow distribution through the baghouse or cyclone. However, it is important to minimize significant pressure surges such as those experienced in March and June.

Exhibits 2.2-34 and 2.2-35 summarize analytical results for the Illinois No. 6 bituminous and Rochelle subbituminous coal and the Coal Creek-Falkirk and Center lignites, respectively.

X-ray fluorescence (XRF) analysis results for the Coal Creek-Falkirk and Center lignite ash samples are also summarized in Exhibit 2.2-35. As expected, the lignite ash contained larger quantities calcium, magnesium, and sodium, reported as oxides, when compared to the Illinois No. 6 coal. When compared to the Rochelle coal, the lignites contained larger quantities of sodium and comparable quantities of calcium. A comparison of the two lignites reveals that the Coal Creek-Falkirk lignite contained larger quantities of silica and alumina, reported as oxides. The Center lignite contained larger quantities of iron, calcium, and sodium, reported as oxides. The higher concentrations of calcium and sodium in the Center lignite were the cause of greater ash deposition and refractory erosion/corrosion observed during the Center lignite test period. 


\section{Exhibit 2.2-34}

Results of Coal and Coal Ash Analysis for Coal-Fired Slagging Furnace Tests

\begin{tabular}{|c|c|c|}
\hline & $\begin{array}{c}\text { Illinois No. } 6 \text { Bituminous } \\
\text { Coal }\end{array}$ & $\begin{array}{l}\text { Rochelle Subbituminous } \\
\text { Coal }\end{array}$ \\
\hline \multicolumn{3}{|l|}{ Proximate Analysis, wt $\%$} \\
\hline Moisture & $8.50-10.30$ & $21.60-24.30$ \\
\hline Volatile Matter & $35.89-36.30$ & $35.58-37.39$ \\
\hline Fixed Carbon & $43.26-44.78$ & $35.82-36.72$ \\
\hline Ash & $10.55-10.76$ & $4.30-4.68$ \\
\hline \multicolumn{3}{|l|}{ Ultimate Analysis, wt $\%$} \\
\hline Hydrogen & $5.55-5.81$ & $6.07-6.37$ \\
\hline Carbon & $61.62-63.36$ & $53.00-55.19$ \\
\hline Nitrogen & $1.01-1.06$ & $0.64-0.66$ \\
\hline Sulfur & $3.24-3.35$ & $0.24-0.28$ \\
\hline Oxygen & $16.13-17.64$ & $32.93-33.43$ \\
\hline Ash & $10.55-10.76$ & $4.30-4.68$ \\
\hline Heating Value, Btu/lb & $11,036-11,658$ & $9021-9328$ \\
\hline \multicolumn{3}{|l|}{ Percent as Oxides, wt $\%$} \\
\hline $\mathrm{SiO}_{2}$ & $52.8-53.9$ & $26.7-27.1$ \\
\hline $\mathrm{Al}_{2} \mathrm{O}_{3}$ & $20.6-21.2$ & $15.5-16.3$ \\
\hline $\mathrm{Fe}_{2} \mathrm{O}_{3}$ & $13.6-14.3$ & $6.3-6.6$ \\
\hline $\mathrm{TiO}_{2}$ & 0.9 & $1.2-1.4$ \\
\hline $\mathrm{P}_{2} \mathrm{O}_{5}$ & $0.1-0.2$ & $0.7-0.9$ \\
\hline $\mathrm{CaO}$ & $3.2-3.5$ & $21.6-24.3$ \\
\hline $\mathrm{MgO}$ & $1.5-1.6$ & $6.7-6.9$ \\
\hline $\mathrm{Na}_{2} \mathrm{O}$ & 1.1 & 1.5 \\
\hline $\mathrm{K}_{2} \mathrm{O}$ & $1.9-2.1$ & $0.1-0.4$ \\
\hline $\mathrm{SO}_{3}$ & $2.5-2.7$ & $15.6-17.0$ \\
\hline \multicolumn{3}{|l|}{ Ash Fusion Temp., ${ }^{\circ} \mathrm{F}$} \\
\hline Initial & $2327-2346$ & $2202-2295$ \\
\hline Softening & $2362-2363$ & $2205-2308$ \\
\hline Hemisphere & $2409-2411$ & $2214-2311$ \\
\hline Fluid & $2505-2534$ & $2221-2325$ \\
\hline \multicolumn{3}{|l|}{ Sieve Analysis } \\
\hline Screen Mesh Size & \multicolumn{2}{|c|}{ wt $\%$ Retained } \\
\hline 100 & $5.8-6.2$ & $7.6-8.8$ \\
\hline 140 & $0-11.2$ & $14.2-15.4$ \\
\hline 170 & $0-14.9$ & NA \\
\hline 200 & $9.6-13.5$ & $14.3-14.4$ \\
\hline 230 & 0-9.0 & $8.4-9.1$ \\
\hline 270 & $6.2-14.6$ & $2.0-5.6$ \\
\hline 325 & $8.6-8.9$ & $4.8-11.6$ \\
\hline 400 & $0-4.7$ & NA \\
\hline Pan & $41.6-44.4$ & $39.7-43.4$ \\
\hline Total \% & $99-100.2$ & $98.6-100.6$ \\
\hline
\end{tabular}

${ }^{1}$ Coal analysis is presented on an "as-fired" basis. 


\section{Exhibit 2.2-35 \\ Results of Lignite and Lignite Ash Analysis for Lignite-Fired Slagging Furnace Tests}

\begin{tabular}{|c|c|c|}
\hline & Coal Creek-Falkirk Lignite & Center Lignite \\
\hline \multicolumn{3}{|c|}{ Proximate Analysis, wt $\%$} \\
\hline Moisture & $31.60-37.90$ & $33.80-37.10$ \\
\hline Volatile Matter & $29.40-31.48$ & $30.39-32.14$ \\
\hline Fixed Carbon & $26.36-26.76$ & $26.91-27.87$ \\
\hline Ash & $6.34-10.16$ & $5.59-6.19$ \\
\hline \multicolumn{3}{|l|}{ Ultimate Analysis, wt $\%$} \\
\hline Hydrogen & $6.41-6.78$ & $6.95-7.16$ \\
\hline Carbon & $38.52-40.91$ & $41.11-43.35$ \\
\hline Nitrogen & $0.57-0.61$ & $0.57-0.58$ \\
\hline Sulfur & $0.49-0.74$ & $0.69-0.88$ \\
\hline Oxygen & $41.16-47.31$ & $42.06-44.86$ \\
\hline Ash & $6.34-10.16$ & $5.59-6.19$ \\
\hline Heating Value, Btu/lb & $6,300-6,708$ & $6933-7144$ \\
\hline \multicolumn{3}{|l|}{ Percent as Oxides, wt $\%$} \\
\hline $\mathrm{SiO}_{2}$ & $31.8-35.5$ & 11.2 \\
\hline $\mathrm{Al}_{2} \mathrm{O}_{3}$ & $11.7-12.0$ & 8.6 \\
\hline $\mathrm{Fe}_{2} \mathrm{O}_{3}$ & $6.4-8.0$ & 13.2 \\
\hline $\mathrm{TiO}_{2}$ & 0.5 & 0.2 \\
\hline $\mathrm{P}_{2} \mathrm{O}_{5}$ & 0.3 & 0.1 \\
\hline $\mathrm{CaO}$ & $17.0-18.7$ & 21.3 \\
\hline $\mathrm{MgO}$ & $6.5-7.0$ & 7.3 \\
\hline $\mathrm{Na}_{2} \mathrm{O}$ & $2.9-3.2$ & 11.7 \\
\hline $\mathrm{K}_{2} \mathrm{O}$ & 1.3 & 0.2 \\
\hline $\mathrm{SO}_{3}$ & $16.0-19.0$ & 26.2 \\
\hline \multicolumn{3}{|l|}{ Ash Fusion Temp., ${ }^{\circ} \mathrm{F}$} \\
\hline Initial & $2170-2188$ & $2370-2371$ \\
\hline Softening & 2181-2196 & $2381-2384$ \\
\hline Hemisphere & $2189-2203$ & 2384-2387 \\
\hline Fluid & 2196-2219 & $2392-2428$ \\
\hline \multicolumn{3}{|l|}{ Sieve Analysis } \\
\hline Screen Mesh Size & \multicolumn{2}{|c|}{ wt $\%$ Retained } \\
\hline 100 & $6.4-10.3$ & 14.9 \\
\hline 140 & $12.3-13.8$ & 15.7 \\
\hline 170 & NA & 4.6 \\
\hline 200 & $11.9-12.3$ & 8.5 \\
\hline 230 & $3.7-8.5$ & NA \\
\hline 270 & $6.2-10.2$ & 3.1 \\
\hline 325 & $6.4-6.5$ & 14.9 \\
\hline 400 & NA & NA \\
\hline Pan & $41.5-48.2$ & 38.2 \\
\hline Total \% & 98.3-99.9 & 99.9 \\
\hline
\end{tabular}




\section{Slagging Furnace Operation}

The slagging furnace heatup rate during the April and June test periods was limited to $50^{\circ} \mathrm{F} / \mathrm{hr}$ $\left(28^{\circ} \mathrm{C} / \mathrm{hr}\right)$ and $150^{\circ} \mathrm{F} / \mathrm{hr}\left(83^{\circ} \mathrm{C} / \mathrm{hr}\right)$, respectively, or less while natural gas was fired. The slower heatup rate in April was necessary to cure new refractory in the furnace and slag screen. When the main burner natural gas firing rate reached 2.6 to $2.7 \mathrm{MMBtu} / \mathrm{hr}\left(2.7\right.$ to $2.8 \times 10^{6} \mathrm{~kJ} / \mathrm{hr}$ ), it was held for about 4 hours before lignite firing was initiated to ensure the furnace and slag screen high-density refractory surfaces were preheated adequately to support slag flow. An additional 4 hours of lignite firing were necessary for the entire furnace to come to thermal equilibrium as determined by refractory temperature measurements. Summaries of furnace and slag screen temperatures are presented as a function of run time in Exhibits 2.2-36 and 2.2-37 for the April and June RAH panel tests, respectively. Corresponding slagging furnace firing rates are summarized in Exhibits 2.2-38 and 2.2-39.

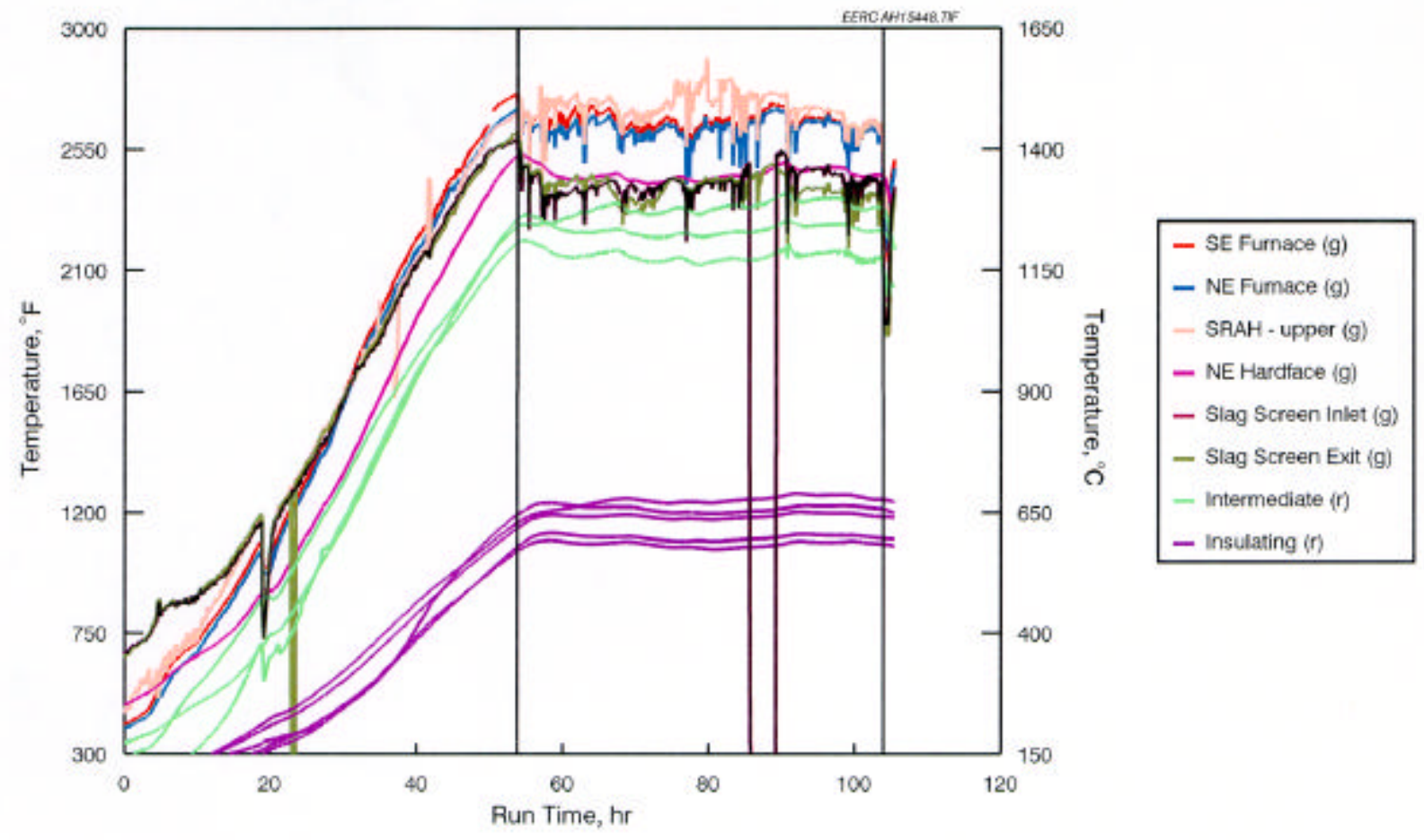

Exhibit 2.2-36

Furnace and Slag Screen Temperatures versus Run Time for the April 1998 Test Period 


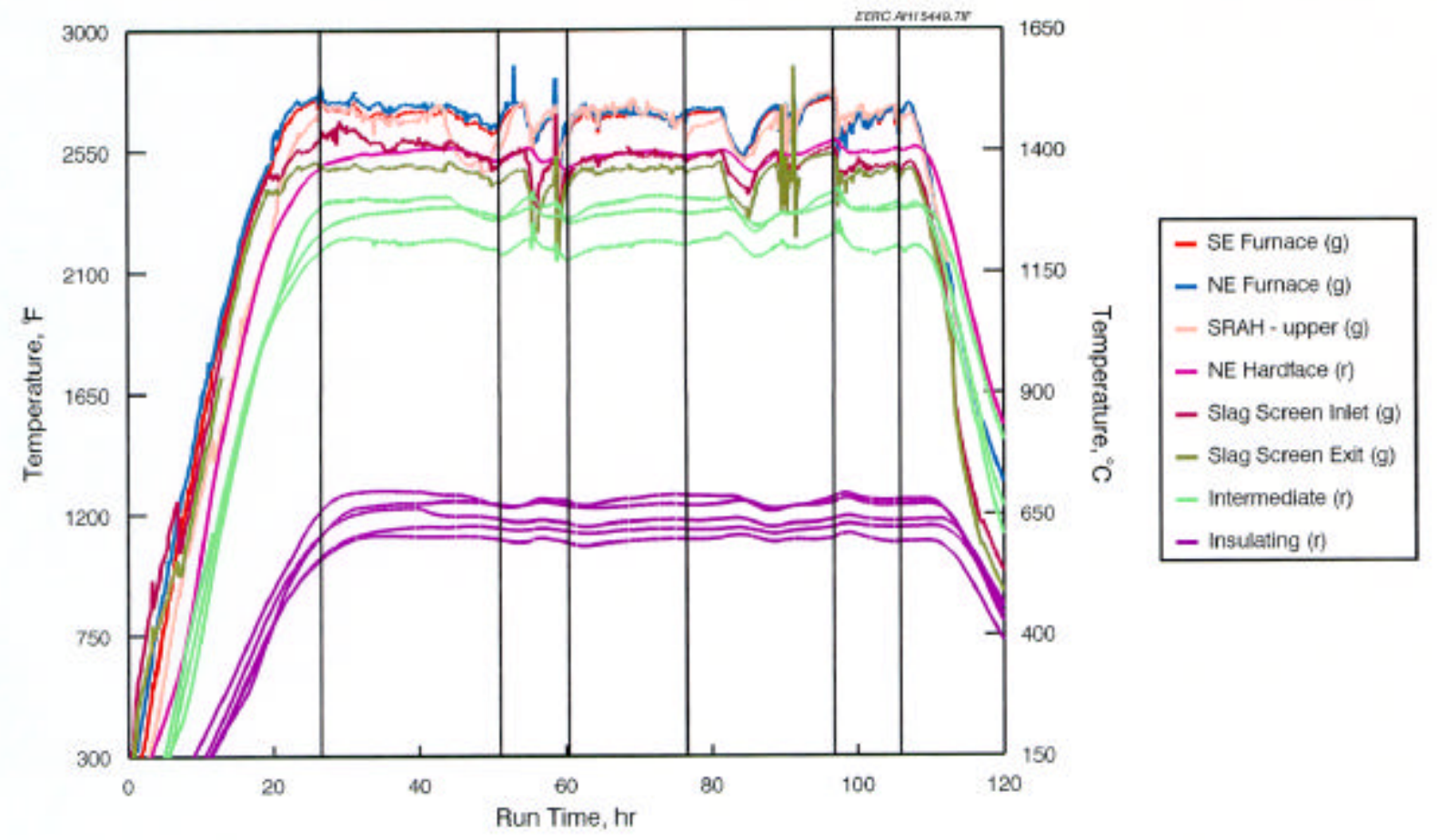

Exhibit 2.2-37

Furnace and Slag Screen Temperatures versus Run Time for the June 1998 Test Period

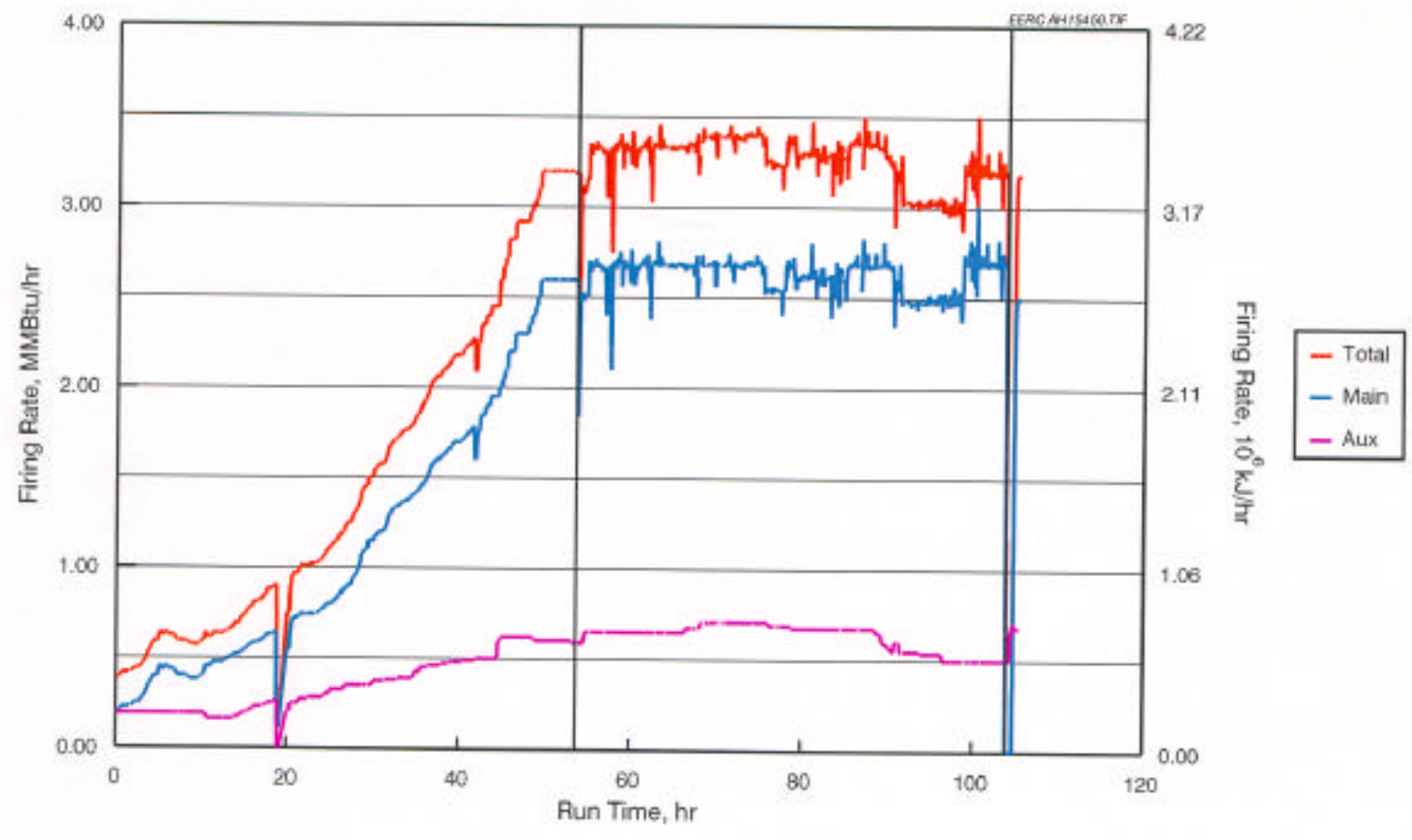

Exhibit 2.2-38

Slagging Furnace Firing Rate versus Run Time for the April 1998 Test Period 


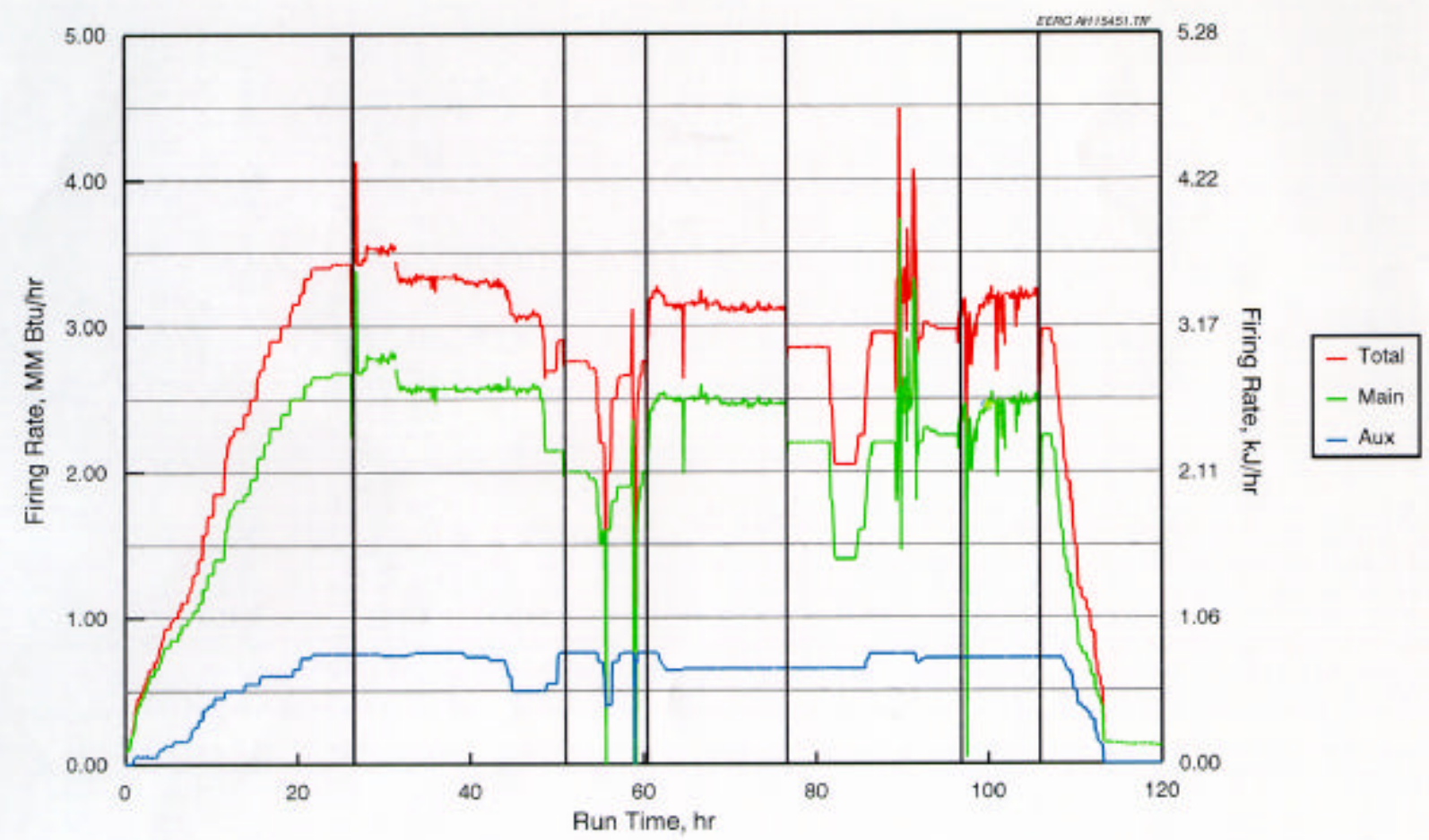

Exhibit 2.2-39

Slagging Furnace Firing Rate versus Run Time for the June 1998 Test Period

During the week of April 19-24 (SFS-ND1-0398), the furnace was fired on Coal Creek-Falkirk lignite at $100 \%$ load. The purpose of the weeklong operating period was to evaluate the LRAH and SRAH panels while firing lignite. Once furnace heatup was completed, the total furnace-firing rate ranged from 3.0 to $3.4 \mathrm{MMBtu} / \mathrm{hr}\left(3.1\right.$ to $\left.3.5 \times 10^{6} \mathrm{~kJ} / \mathrm{hr}\right)$. Prior to installation of the SRAH panel furnace firing rates exceeding $3 \mathrm{MMBtu} / \mathrm{hr}\left(3.1 \times 10^{6} \mathrm{~kJ} / \mathrm{hr}\right)$ only occurred during natural gas-fired tests. However, with the SRAH panel installed it was necessary to increase the firing rate of the main burner in order maintain nominal furnace temperatures of $2700^{\circ}$ to $2800^{\circ} \mathrm{F}\left(1483^{\circ}\right.$ to $\left.1538^{\circ} \mathrm{C}\right)$. Lignite-fired test periods were performed at a main burner firing rate of 2.5 to $2.7 \mathrm{MMBtu} / \mathrm{hr}$ ( 2.6 to $2.8 \times 10^{6} \mathrm{~kJ} / \mathrm{hr}$ ). The main burner accounted for $80 \%$ of the total fuel input on a firing rate basis. During the April test period, no specific attempt was made to maximize and minimize the main and auxiliary burner firing rates, respectively, while controlling the furnace temperature at $2700^{\circ}$ to $2800^{\circ} \mathrm{F}\left(1483^{\circ}\right.$ to $\left.1538^{\circ} \mathrm{C}\right)$.

Once furnace temperatures were stable, the duration of individual test periods ranged from 2 to 8 hours. Five lignite-fired test periods were completed. No system operating problems were encountered during the week other than the lignite feed problems previously described. At $100 \%$ load, furnace temperature was controlled at nominally $2700^{\circ} \mathrm{F}\left(1483^{\circ} \mathrm{C}\right)$, depending on total furnace firing rate, main burner firing rate, and main burner swirl settings. Furnace refractory temperatures ranged from $1050^{\circ}$ to $1250^{\circ} \mathrm{F}\left(566^{\circ}\right.$ to $\left.677^{\circ} \mathrm{C}\right)$ for the insulating refractory to as high as $2460^{\circ} \mathrm{F}\left(1349^{\circ} \mathrm{C}\right)$ for the high-density refractory. When compared to previous test periods with the Illinois No. 6 and Rochelle coals, furnace refractory temperatures were lower during the April lignite test period by $65^{\circ}$ to $115^{\circ} \mathrm{F}\left(36^{\circ}\right.$ to $\left.64^{\circ} \mathrm{C}\right)$ for the insulating refractory and $150^{\circ}$ to 
$180^{\circ} \mathrm{F}\left(83^{\circ}\right.$ to $\left.100^{\circ} \mathrm{C}\right)$ for the high-density refractory. However, a valid comparison of refractory temperatures cannot be made until the Illinois No. 6 bituminous and Rochelle subbituminous coals are fired at $2.6 \mathrm{MMBtu} / \mathrm{hr}\left(2.7 \times 10^{6} \mathrm{~kJ} / \mathrm{hr}\right)$ with the SRAH installed.

During the week of June 7-12 (SFS-ND2-0498), the furnace was preheated to nominally $2700^{\circ} \mathrm{F}\left(1483^{\circ} \mathrm{C}\right)$ on natural gas. Lignite firing (Center lignite) was initiated at Run Hour 26.5 and continued for $24 \mathrm{hr}$ while furnace temperature was controlled at nominally $2700^{\circ} \mathrm{F}\left(1538^{\circ} \mathrm{C}\right)$. The total furnace firing rate ranged from 3.1 to $3.5 \mathrm{MMBtu} / \mathrm{hr}\left(3.2\right.$ to $\left.3.6 \times 10^{6} \mathrm{~kJ} / \mathrm{hr}\right)$. Additional lignite-fired periods of 16 and 10 hours were completed following the correction of operational problems described previously. The primary burner accounted for $78 \%-79 \%$ of the total fuel input during the $50 \mathrm{hr}$ of lignite firing.

Operating problems encountered during the week were related to ash deposition and slag flow and have been previously discussed. At a main burner firing rate of 2.5 to $2.6 \mathrm{MMBtu} / \mathrm{hr}$ ( 2.6 to $2.7 \times 10^{6} \mathrm{~kJ} / \mathrm{hr}$ ), furnace temperature was controlled at nominally $2700^{\circ} \mathrm{F}\left(1483^{\circ} \mathrm{C}\right)$, depending on total furnace firing rate and main burner swirl settings. Furnace refractory temperatures ranged from $1063^{\circ}$ to $1266^{\circ} \mathrm{F}\left(573^{\circ}\right.$ to $\left.686^{\circ} \mathrm{C}\right)$ for the insulating refractory to as high as $2513^{\circ} \mathrm{F}$ $\left(1379^{\circ} \mathrm{C}\right)$ for the high-density refractory. These refractory temperatures (Center lignite) are comparable to those observed for the Coal Creek-Falkirk lignite. Again, a direct comparison at this time with Illinois No. 6 and Rochelle coal data is not appropriate since the SFS has not yet been fired with these fuels with the SRAH panel installed. During the June test period, no specific attempt was made to maximize and minimize the main and auxiliary burner firing rates, respectively, while controlling the furnace temperature at $2700^{\circ} \mathrm{F}\left(1483^{\circ} \mathrm{C}\right)$.

Over the course of the weeklong test periods completed in April and June, the slag tap plugged only once, during the June test. The refractory in the slag tap was replaced before each operating period to repair slag corrosion damage and create a well-defined drip edge. When the slag comes in contact with the cooler walls, it will tend to freeze in place and plug the slag tap area.

Inspection of the furnace refractory after the April and June operating periods indicated severe refractory deterioration. Refractory deterioration was more severe after the June test when compared to the April test period. After the April test period, the areas of the furnace requiring refractory repairs included an area above the RAH panels, the furnace exit, the slag tap, and the slag screen. After the June test period, refractory replacement was necessary in the furnace exit and slag screen, and repairs were required above the RAH panels and the slag tap. Replacement of the high-density refractory in the furnace will be considered following the Illinois No. 6 bituminous coal test planned for August. EERC personnel have not been able to determine a slag deposition rate on the furnace walls or LRAH panel.

\section{Main and Auxiliary Burners}

The main and auxiliary burners performed well during the test periods completed in April and June. Main burner swirl adjustment was more than adequate to establish a stable flame when firing the two lignites. The EERC evaluated main burner swirl settings on LRAH and SRAH panel performance at minimum, moderate, and maximum swirl settings. Adjustments to swirl setting had no effect on carbon efficiency because of the high furnace operating temperature and the reactive characteristics of lignite. At this time, the EERC suggests that the slagging furnace 
continue to be operated using minimum-to-moderate primary burner swirl in order to maintain more uniform temperatures over the length of the furnace and minimize $\mathrm{NO}_{\mathrm{x}}$ emissions. $\mathrm{RAH}$ test periods should continue to include adjustments to primary burner swirl.

\section{Slag Screen}

Inspection of the slag screen after the lignite-fired (Coal Creek-Falkirk) test period in April demonstrated more high-density refractory deterioration when compared to the Illinois No. 6 bituminous coal. Refractory attack was somewhat less with the Rochelle subbituminous coal compared to operation with the Coal Creek-Falkirk lignite. Although no refractory replacement was required after the April test, some patching of the floor was necessary. Slag screen inspection after the June test period (Center lignite) indicated that the refractory deterioration was even more severe. The refractory in the floor was in poor condition, and the first three rows of tubes were eroded to a significant degree. Therefore, it will be necessary to replace the slag screen tubes and refractory before the next test planned for August. The greater refractory erosion/corrosion observed as a result of firing the Center lignite are consistent with the higher alkali (sodium and calcium) content of the ash in the fuel.

Inspection of the slag screen following $50 \mathrm{hr}$ of coal firing in April and another $50 \mathrm{hr}$ in June indicated that the slag observed flowing through the slag tap came from the slag screen as well as down the walls of the furnace. During both weeks of operation, there was evidence of slag/refractory flowing down the surface of the RAH panels and into the slag tap. Previous operation of the SFS with the bituminous and subbituminous coals had not resulted in any indication of slag reaching the slag tap from the RAH panels. The combination of ash quantity, ash chemistry, and greater refractory deterioration in the upper furnace is believed to be the reason for slag flow from the RAH panels into the slag tap. Based on the amount and appearance of the slag on the surface of the RAH panels, a greater percentage of the material appears to be refractory rather than lignite ash and slag. However, it is impossible to estimate a mass ratio or rate.

As a function of system maintenance, following each weeklong test, EERC personnel collected and weighed slag and ash samples from system components and piping in order to prepare a mass balance. A total theoretical ash quantity was calculated based on the total lignite feed and the measured ash content of the composite lignite sample collected. Total slag and ash recovery from the April and June test periods was $80 \%$ and $61 \%$, respectively. Slag recovery from the furnace, slag pot, and dilution/quench zone represented nominally $69 \%$ and $43 \%$ of the theoretical ash. Additional slag is evident on the furnace wall, in the bottom of the furnace, in the slag screen, and in the upper section of the dilution/quench zone. However, this material is not recoverable without damaging the refractory.

The EERC estimates that this unrecoverable slag represents at least $5 \%$ of the theoretical ash. Based on this estimate, $50 \%$ to $75 \%$ of the lignite ash was captured in the system as slag, primarily by the slag screen. The smaller percentage of Center lignite ash collected as slag is related to ash chemistry. A greater percentage of the Center lignite ash was volatilized in the slagging furnace because of its greater alkali content. These alkali components subsequently condensed at lower temperatures primarily as sulfates. Some of the unrecovered lignite ash, possibly $5 \%$ to $10 \%$, is actually present as unrecoverable slag. Based on these estimates, the slag would represent roughly $55 \%$ to $85 \%$ of the total ash, depending on specific ash chemistry. The 
actual value is most likely somewhere between. Also, it is not possible to determine what fraction of the recovered slag is actually refractory from the furnace or slag screen. The $80 \%$ closure on ash and slag for the Coal Creek-Falkirk lignite was lower but comparable to recent results with the Illinois No. 6 (95\%) and Rochelle (85\%) coals. In the case of the Center lignite (61\%), poor ash and slag recovery is believed to be directly related to the ash chemistry. However, the sulfated species should have been recovered as ash deposits in areas of lower flue gas temperature or in the pulse-jet baghouse. Further investigation will be necessary to explain the low ash and slag recovery for the Center lignite test.

Fly ash recovered from other system components (drawdown gas line, CAH duct, CA preheater tubes, tube-and-shell heat exchangers, cyclone, baghouse, and flue gas piping) represents $8 \%$ to $16 \%$ of the theoretical ash. Nominally $10 \%$ to $15 \%$ of the ash in the fuels fired in the SFS is reaching the baghouse. Mass balances will be completed for all future test periods in order to further document the distribution of slag and ash in the system.

The slag screen tubes showed some damage as a result of erosion/corrosion during the April test (Coal Creek-Falkirk lignite). However, they were still intact, and no repairs were required prior to the June test (Center lignite). Exhibit 2.2-40 presents a photograph of the high-aluminacontent ceramic/refractory slag screen tubes after the April test. The first row of tubes was destroyed as a result of a loss in cooling water flow previously discussed. The remaining 15 tubes show signs of refractory erosion/corrosion but are generally in good shape.

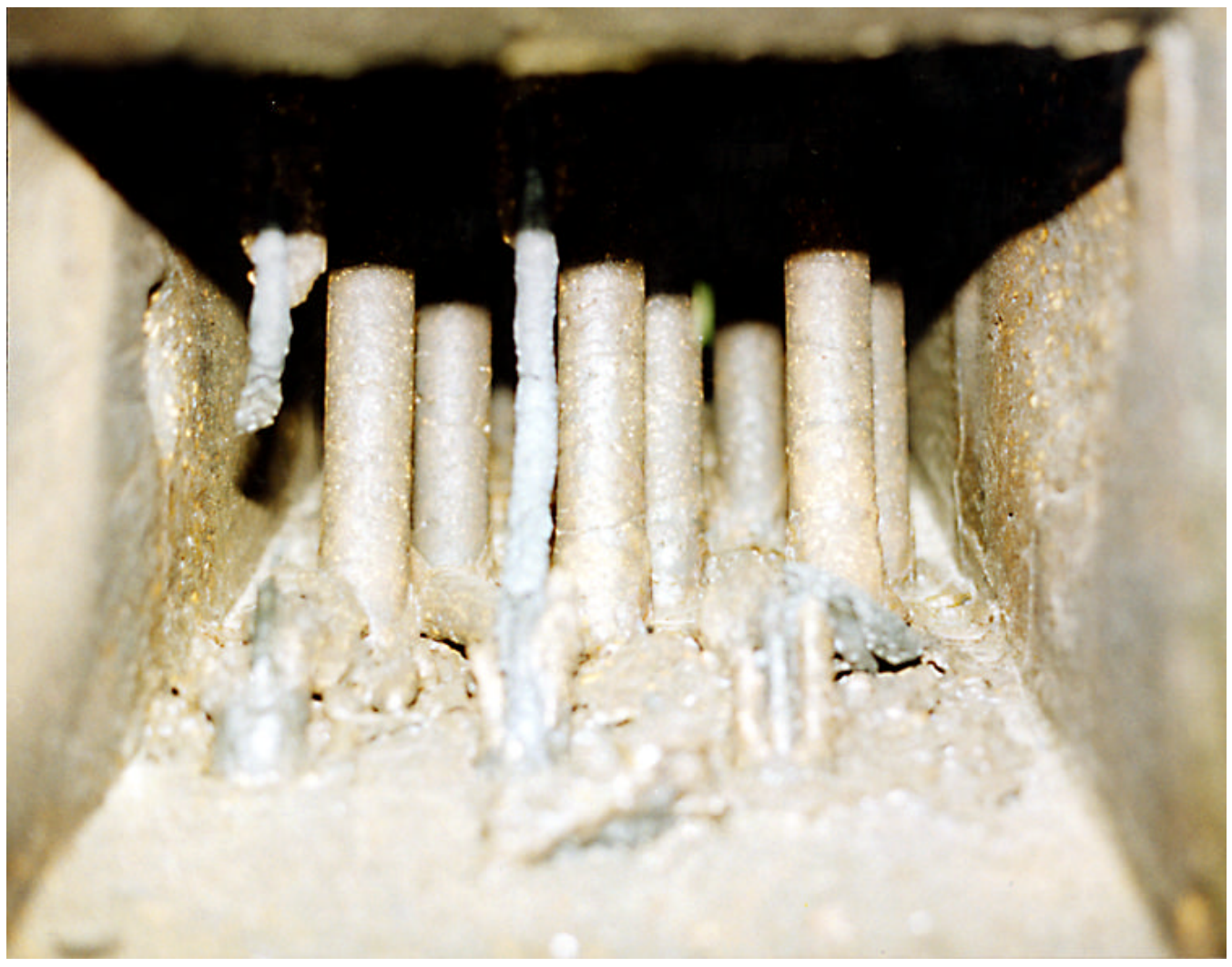

Exhibit 2.2-40

Photograph of Slag Screen Tubes from April Test Period 
After the June test period, the condition of the slag screen was worse. More severe erosion/corrosion was evident. More than $50 \%$ of each tube in the first row has been eroded/corroded away. The tubes in the second and third rows are eroded but to a lesser degree. Only the last two rows of tubes appear to be in good shape, with a definite slag layer present and little erosion/corrosion evident.

Earlier efforts involving cooling of the slag screen tubes were marginally successful. More cooling was apparently needed to build up a sufficiently thick slag layer to protect the slag screen tubes from the severe erosion/corrosion attack that occurs within the slag screen. The diameter of the stainless steel tubes installed in the 18 refractory slag screen tubes was increased to 0.375 in. $(0.952 \mathrm{~cm})$ OD for lignite testing. Increased cooling was beneficial, allowing the slag screen to be successfully used for two weeklong test periods before replacement was necessary. The first row of tubes was lost during the first lignite test when the water flow was accidentally shut off for a short period while looking for a water leak that was subsequently found in the flue gas watercooled probe. With the first row missing, the second and third rows were reduced in overall diameter (including the frozen slag) to about $1 \mathrm{in}$. While the remaining back rows were still in good condition, the decision was made to rebuild the slag screen prior to the next test period in August.

The slag screen tubes will likely always require periodic replacement based on the fuels selected for testing. At this time, the use of 0.375 -in. $(0.952-\mathrm{cm})$-OD stainless steel tube is believed to be a reasonable compromise to provide adequate cooling to protect the refractory slag screen tubes while limiting slag deposition within the slag screen duct. Some limited water cooling of the slag screen floor and the floor of the furnace exit will be installed prior to the next test period in August to better protect the refractory in these areas from the severe attack experienced previously.

Slag screen flue gas temperatures during the April and June test period were typically $2300^{\circ}$ to $2440^{\circ} \mathrm{F}\left(1260^{\circ}\right.$ to $\left.1338^{\circ} \mathrm{C}\right)$ and $2440^{\circ}$ to $2535^{\circ} \mathrm{F}\left(1338^{\circ}\right.$ to $\left.1391^{\circ} \mathrm{C}\right)$, respectively. Slag screen operating temperature is selected based on ash fusion data for the fuel to be fired. The EERC tries to operate the slag screen at flue gas temperatures of $100^{\circ}$ to $200^{\circ} \mathrm{F}\left(56^{\circ}\right.$ to $\left.112^{\circ} \mathrm{C}\right)$ above the fluid temperature of the fuel ash to ensure slag flow from the slag screen to the slag tap.

\section{Dilution/Quench Zone}

Inspection of the dilution/quench zone after each lignite-fired test completed this past quarter showed some slag deposits had formed in the vicinity of the FGR nozzles. However, it was not necessary to dislodge slag deposits from the dilution/quench zone during either week of operation. Longer periods of lignite-fired operation would have required periodic on-line dilution/quench zone cleaning to avoid plugging and a potential forced shutdown. Downstream of the FGR nozzles, the small quantity of ash observed on the refractory walls was weakly sintered.

\section{CA Preheaters}

During the April and June test periods, the cooling air for the CAH tube bank and the LRAH panel was heated using air preheater tube bundles located downstream of the CAH. Further heating of the cooling air entering the LRAH panel was achieved electrically and by recovering heat from the $\mathrm{CAH}$ tube bank. Cooling air for the CAH tube bank is supplied by the first CA preheater tube bundle. During the April lignite-fired test period, cooling air entering the $\mathrm{CAH}$ 
tube bank was controlled at set points ranging from 1050 to $1150^{\circ} \mathrm{F}\left(566^{\circ}\right.$ to $\left.621^{\circ} \mathrm{C}\right)$ for nominal CA flow rates of 60 to $125 \mathrm{scfm}\left(1.7\right.$ to $\left.3.5 \mathrm{~m}^{3} / \mathrm{min}\right)$. CA temperatures at the exits of the other four preheater tube bundles were nominally 1250 to $1355^{\circ} \mathrm{F}\left(677^{\circ}\right.$ to $\left.735^{\circ} \mathrm{C}\right)$ for flow rates totaling 105 to $180 \mathrm{scfm}\left(3.0\right.$ to $\left.5.1 \mathrm{~m}^{3} / \mathrm{min}\right)$.

During the June lignite test, cooling air entering the $\mathrm{CAH}$ tube bank was controlled at set points ranging from 1035 to $1100^{\circ} \mathrm{F}\left(558^{\circ}\right.$ to $\left.594^{\circ} \mathrm{C}\right)$ for nominal CA flow rates of 100 to 150 scfm $\left(2.8\right.$ to $\left.4.2 \mathrm{~m}^{3} / \mathrm{min}\right)$. CA temperatures at the exits of the other four preheater tube bundles were nominally 1250 to $1335^{\circ} \mathrm{F}\left(677\right.$ to $\left.724^{\circ} \mathrm{C}\right)$. The total CA flow rate from Preheaters 2 through 5 ranged from nominally 105 to $180 \mathrm{scfm}\left(3.0\right.$ to $\left.5.1 \mathrm{~m}^{3} / \mathrm{min}\right)$.

CA preheater temperatures are shown as a function of run time in Exhibits 2.2-41 and 2.2-42 for the April and June tests, respectively. The temperature spikes to low levels in Exhibit 2.2-41 at about Run Hours 55 and 91 correspond to the removal and cleaning of a thermocouple. The temperature spike to a high level at about Run Hour 88 resulted from a thermocouple failure and subsequent replacement. Because the CA preheater heat-transfer rate degraded with time as ash deposits developed on the tube surfaces, CA temperature and flow rate control were marginally adequate to support operation of the CAH tube bank and the LRAH panel. If lignite firing were expected to become routine, the installation of additional heat-transfer surface or electrical heaters would be required to achieve adequate CA temperature control. However, additional heaters are not necessary at this time to achieve operational objectives with bituminous and subbituminous coal. 


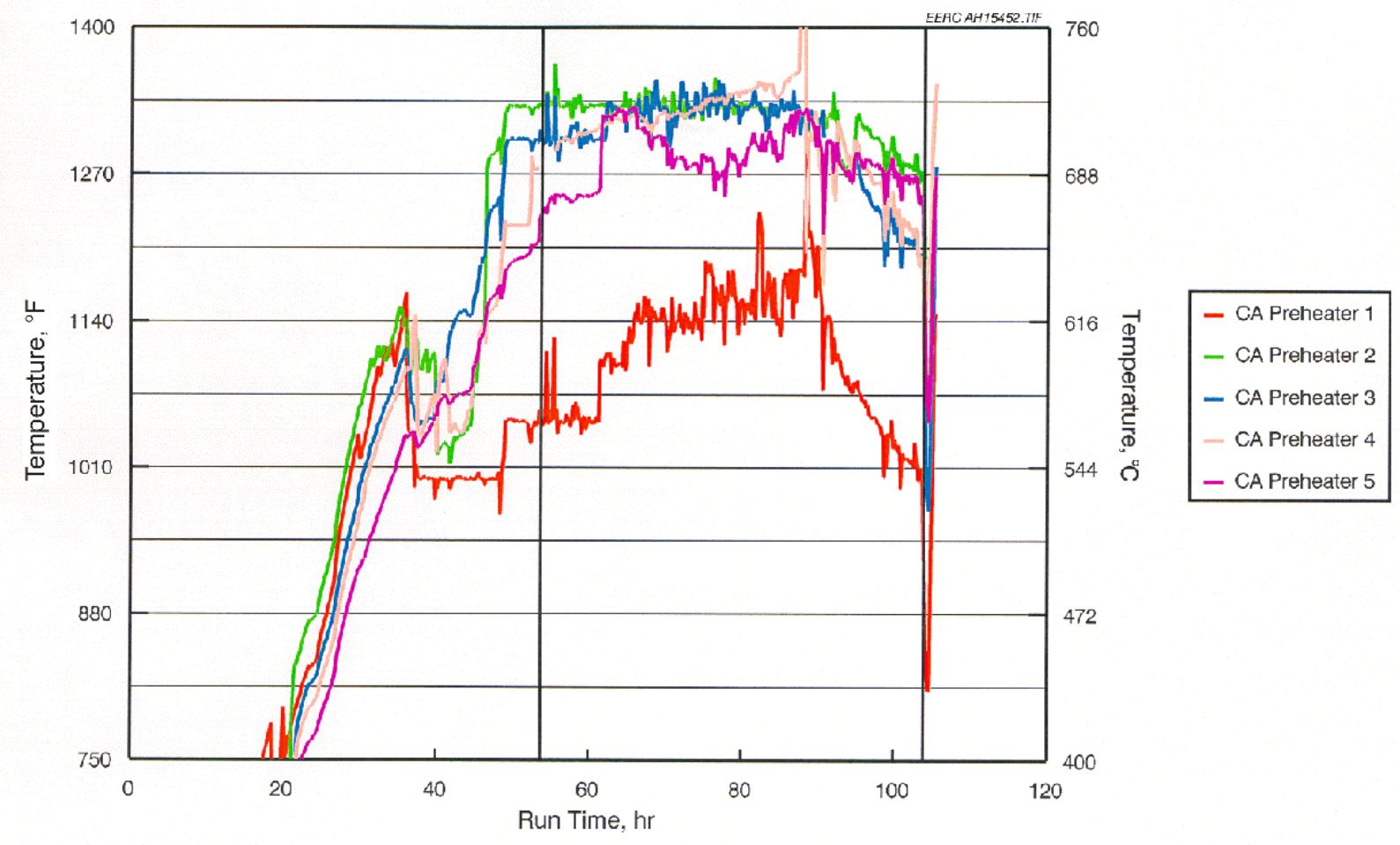

Exhibit 2.2-41

Cooling Air Preheater Temperatures versus Run Time for the April Test Period 


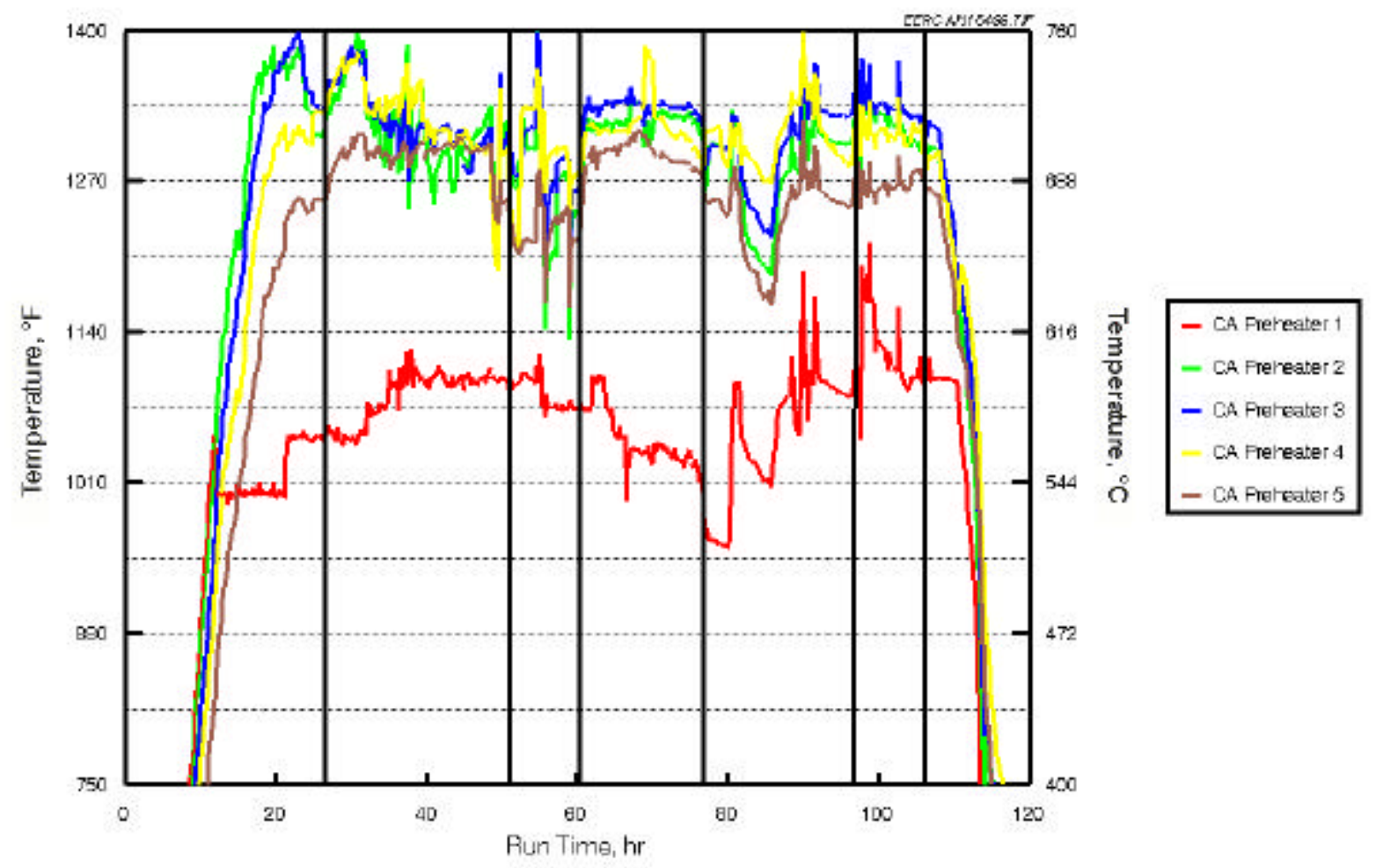

Exhibit 2.2-42

\section{Cooling Air Preheater Temperatures versus Run Time for the June Test Period}

\section{Emission Control}

During gas- and lignite-fired furnace operation in April and June, baghouse temperatures and temperature profiles looked good, and the electrical heaters worked well, limiting the potential for condensation on start-up and shutdown. Measured inlet and outlet particulate mass loadings were nominally $0.17 \mathrm{gr} / \mathrm{scf}\left(389 \mathrm{mg} / \mathrm{Nm}^{3}\right)$ and $0.0002 \mathrm{gr} / \mathrm{scf}\left(0.46 \mathrm{mg} / \mathrm{Nm}^{3}\right)$, respectively, resulting in a particulate collection efficiency of roughly $99.9 \%$ when the Coal Creek-Falkirk lignite was fired in April. Measured inlet and outlet particulate loadings were nominally $0.29 \mathrm{gr} / \mathrm{scf}\left(664 \mathrm{mg} / \mathrm{Nm}^{3}\right)$ and $0.002 \mathrm{gr} / \mathrm{scf}\left(4.58 \mathrm{mg} / \mathrm{Nm}^{3}\right)$, respectively, resulting in a particulate collection efficiency of roughly $99.3 \%$ when the Center lignite was fired in June. The measured inlet particulate loadings are roughly an order of magnitude lower than what would be expected in a more conventional pulverized lignite-fired system. Calculated particulate emissions from the pulse-jet baghouse on a lb/MMBtu basis were 0.0007 for the Coal Creek-Falkirk lignite and 0.0074 for the Center lignite.

The obvious question concerns the order-of-magnitude difference in the particulate emissions for the two lignites. Upon inspection of the pulse-jet baghouse after the June test, small holes were found in five of the 36 bags. The bags were inspected following the April test period, and no holes were evident. EERC personnel believe that the holes in the bags formed during the June test period as a result of the bags rubbing on internal baghouse support material during cleaning cycles. Therefore, if the holes in the bags had not developed, the particulate emissions would have been similar for both lignite fuels. A comparison with particulate data previously generated for the Illinois No. 6 and Rochelle coals shows that the lignite particulate emissions were slightly greater 
than the emissions observed when firing the Rochelle subbituminous coal and less than the emissions observed when firing the Illinois No. 6 bituminous coal. A more detailed discussion of baghouse performance will be presented in the final project report.

Exhibit 2.2-43 shows the average gaseous emissions measured at the slag screen outlet during April and June lignite-fired periods. The data are based on furnace exit measurements made in the slag screen outlet. No attempt at controlling sulfur emissions was made. The carbon monoxide concentrations approaching $40 \mathrm{ppm}$ are a direct result of firing the slag tap burners slightly fuelrich occasionally in order to maximize slag tap temperature and promote slag flow through the slag tap. The auxiliary burner firing condition is also believed to have affected the $\mathrm{NO}_{\mathrm{x}}$ concentrations and the fact that $\mathrm{NO}_{\mathrm{x}}$ concentrations were comparable for both lignites as well as the bituminous and subbituminous coals previously fired in the SFS.

\begin{tabular}{ccc}
\multicolumn{4}{c}{$\begin{array}{c}\text { Exhibit 2.2-43 } \\
\text { Flue Gas Emissions for Lignite-Fired Slagging Furnace Tests }\end{array}$} \\
\hline \multicolumn{3}{c}{ Concentration } \\
\hline April & & \\
$\mathrm{O}_{2}$ & $3.0 \%-4.0 \%$ & \\
$\mathrm{CO}_{2}$ & $14.0 \%-15.0 \%$ \\
$\mathrm{CO}$ & $10-40 \mathrm{ppm}$ \\
$\mathrm{NO}_{\mathrm{x}}$ & $400-470 \mathrm{ppm}$ & $0.65-0.75$ \\
$\mathrm{SO}_{2}$ & $630-720 \mathrm{ppm}$ & $1.4-1.6$ \\
$\mathrm{June}$ & & \\
$\mathrm{O}_{2}$ & $3.0 \%-4.0 \%$ & \\
$\mathrm{CO}_{2}$ & $14.2 \%-15.3 \%$ & \\
$\mathrm{CO}$ & $10-40 \mathrm{ppm}$ & \\
$\mathrm{NO}_{\mathrm{x}}$ & $450-620 \mathrm{ppm}$ & $0.64-0.84$ \\
$\mathrm{SO}_{2}$ & $590-720 \mathrm{ppm}$ & $1.16-1.42$ \\
\hline
\end{tabular}

\section{Testing of the CAH Tube Bank}

The CAH tube bank was installed and initially evaluated during a shakedown test completed in October 1997. CA flow rate was adequate for nominal temperature control and the performance of the CAH tube bank during this past quarter of testing. Exhibits 2.2-44 through 2.2-46 summarize $\mathrm{CAH}$ tube bank surface and flue gas temperatures, $\mathrm{CA}$ temperatures, and CA flow rate data for the April test period. Exhibit 2.2-47 illustrates the location of thermocouples in the CAH tube bank, and Exhibit 2.2-48 presents a list of thermocouple descriptions. 


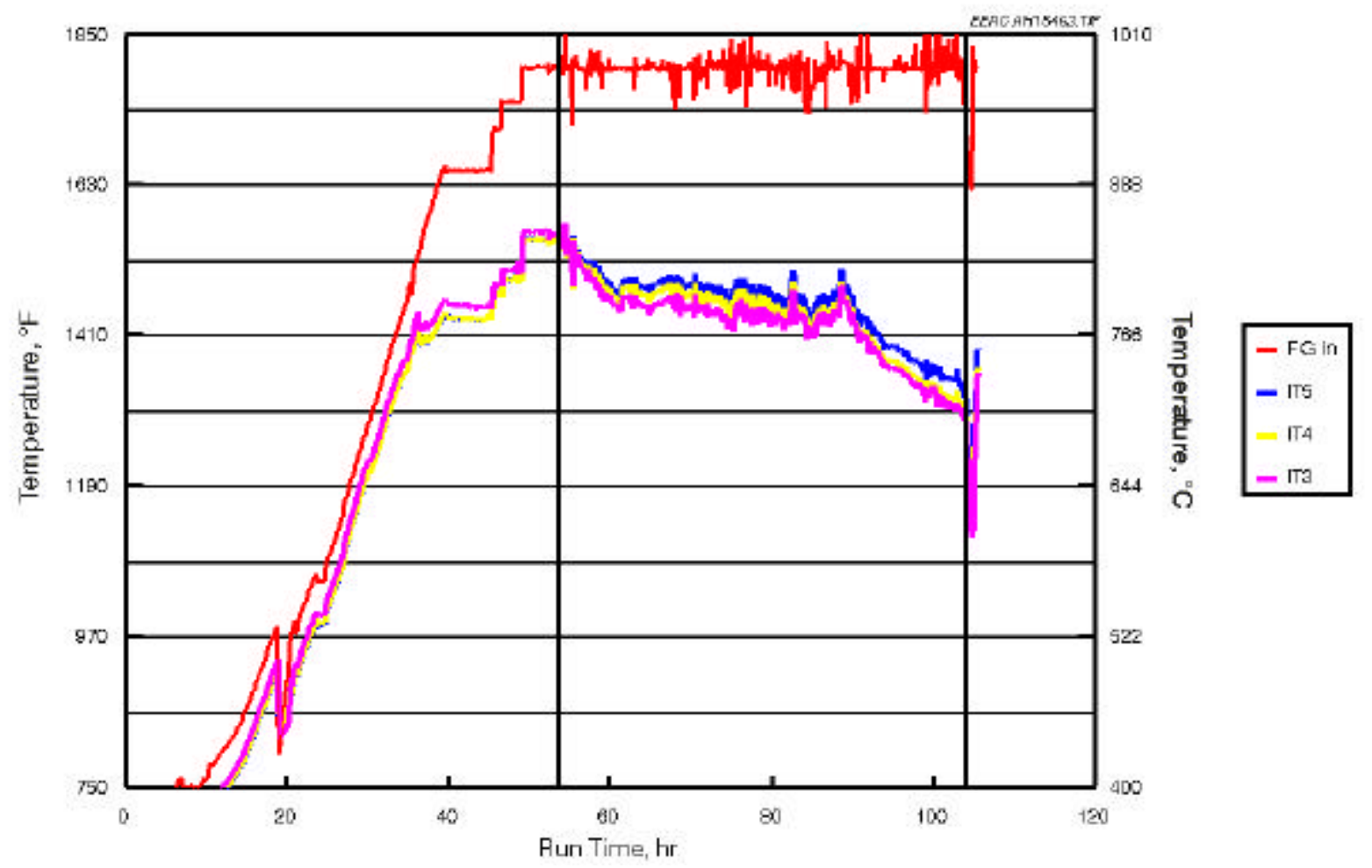

Exhibit 2.2-44

CAH Tube Surface and Flue Gas Temperatures versus Run Time for the April Test Period 


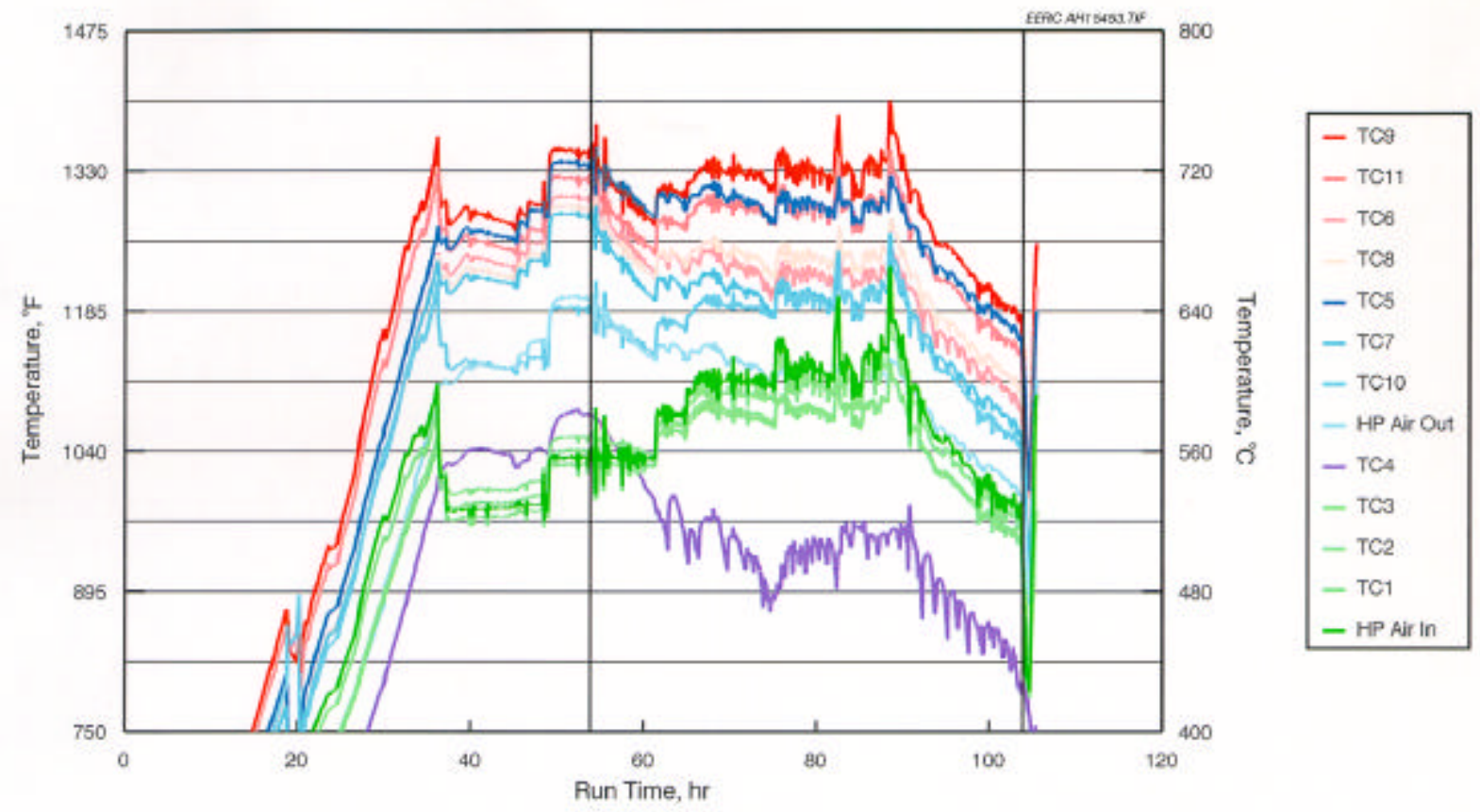

Exhibit 2.2-45

CAH Cooling Air Temperatures versus Run Time for the April Test Period 


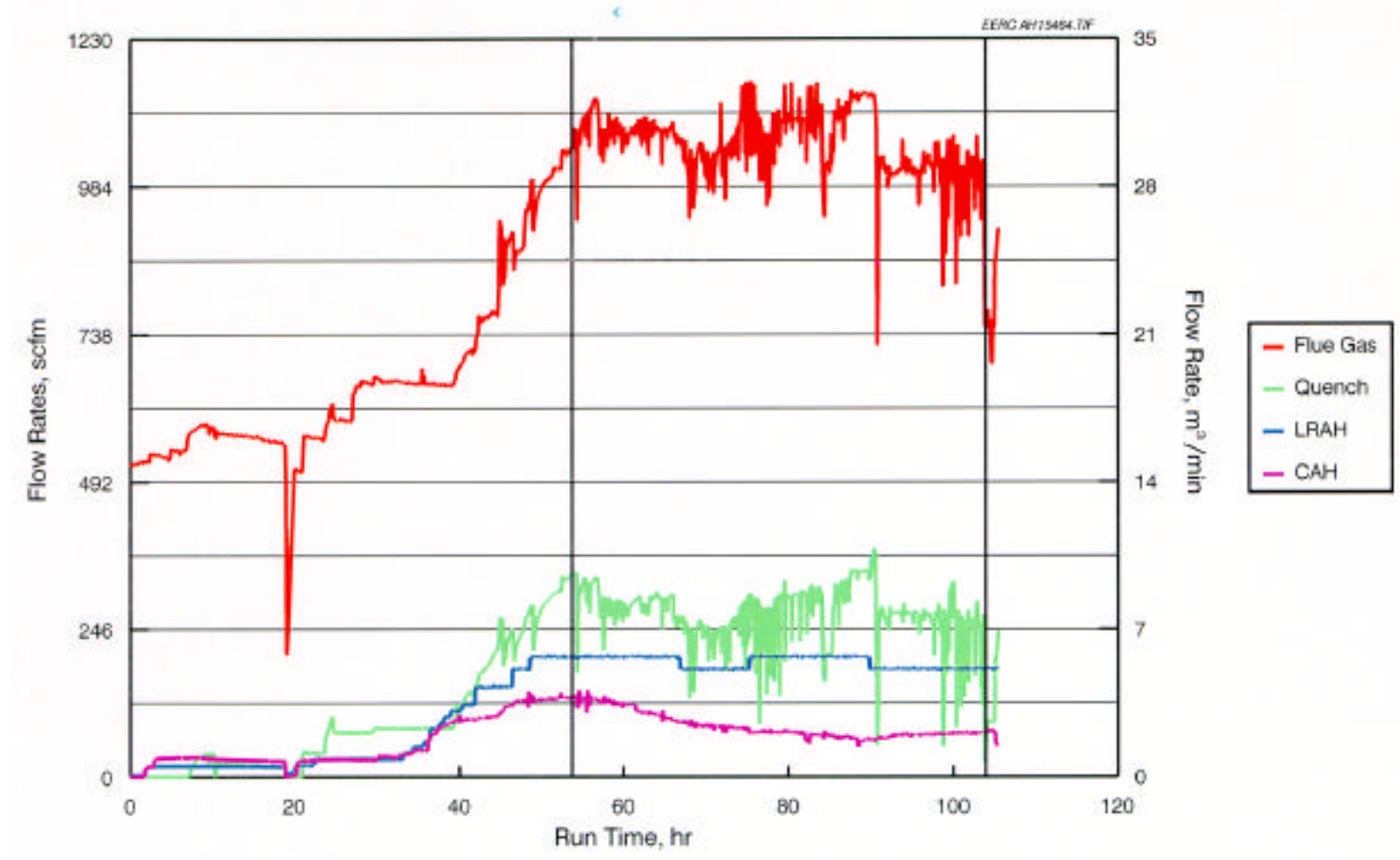

Exhibit 2.2-46

CAH Cooling Air, LRAH Cooling Air, Quench Gas, and Glue Gas Flow Rates versus Run Time for the April Test Period 


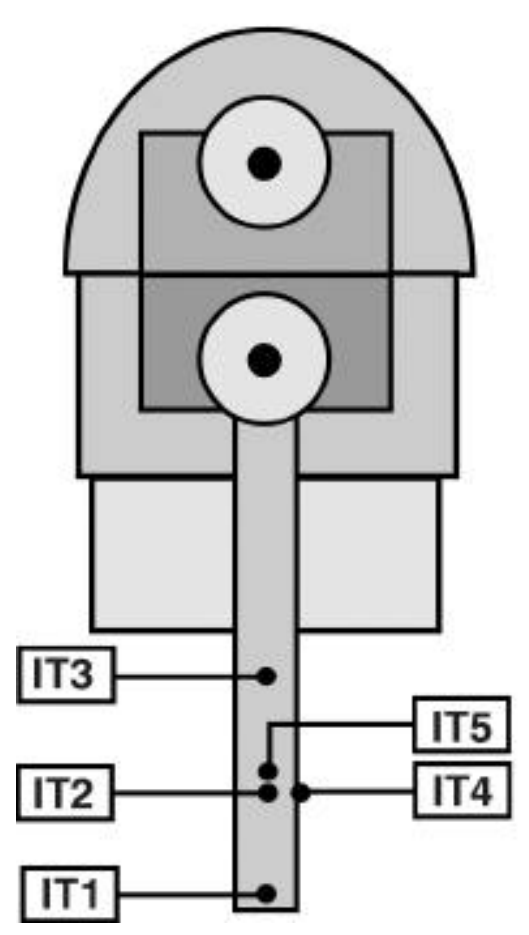

\section{Thermocouple Locations in the CAH Tube Bank}

As a result of exposure to flue gas conditions and attempts at tube cleaning, three tube surface thermocouples (CAHIT1, CAHIT2, and CAHIT4) had failed prior to the April test period. CAHIT1 and CAHIT4 were damaged during a cleaning attempt during the February test period. CAHIT2 was damaged during the March test period. Thermocouple CAHIT4 was repaired prior to the April test period, but the other two thermocouples were not repaired. During the June test period, only two tube surface thermocouples appeared to be working correctly, CAHIT3 and CAHIT5.

The surface temperature and CA flow rate data indicate that when the tubes are clean, it is necessary to either increase the CA flow rate to a level $>100 \mathrm{scfm}\left(>2.83 \mathrm{~m}^{3} / \mathrm{min}\right)$ or reduce the temperature of the flue gas entering the $\mathrm{CAH}$ tube bank to $<1800^{\circ} \mathrm{F}\left(<982^{\circ} \mathrm{C}\right)$ to prevent the overheating of the metal tube surfaces. While natural gas was fired, heat recovery from the CAH tube bank was roughly $45,000 \mathrm{Btu} / \mathrm{hr}(47,475 \mathrm{~kJ} / \mathrm{hr})$ for a CA flow rate of $130 \mathrm{scfm}\left(3.7 \mathrm{~m}^{3} / \mathrm{min}\right)$, an inlet CA temperature of $1035^{\circ} \mathrm{F}\left(558^{\circ} \mathrm{C}\right)$, an outlet CA temperature of $1200^{\circ} \mathrm{F}\left(649^{\circ} \mathrm{C}\right)$, and a flue gas temperature of $1800^{\circ} \mathrm{F}\left(983^{\circ} \mathrm{C}\right)$ entering the $\mathrm{CAH}$ tube bank. Exhibit $2.2-49$ presents heat recovery in the $\mathrm{CAH}$ as a function of run time for the April test. 


\begin{tabular}{|c|c|c|c|}
\hline \multicolumn{4}{|c|}{$\begin{array}{c}\text { Exhibit 2.2-48 } \\
\text { Description of CAH Thermocouple Locations }\end{array}$} \\
\hline Category & No. & Label & Description \\
\hline \multirow[t]{3}{*}{ Air Inlet } & 1 & CAHTC1 & Bulk flow entering the inlet header \\
\hline & 2 & CAHTC2 & Air entering center tube \\
\hline & 3 & CAHTC3 & Air entering most downstream tube \\
\hline \multirow[t]{4}{*}{ Air Outlet } & 4 & САHТC6 & Air leaving center tube \\
\hline & 5 & CAHTC7 & Air leaving most downstream tube \\
\hline & 6 & CAHTC5 & Air leaving most upstream tube \\
\hline & 7 & CAHTC8 & Air leaving side tube \\
\hline \multirow[t]{3}{*}{ Air in Active Region } & 8 & САНТC10 & Bottom of center tube \\
\hline & 9 & CAHTC11 & 4" up outside annulus, center tube \\
\hline & 10 & САНТС9 & $8 "$ up outside annulus, center tube \\
\hline \multirow[t]{5}{*}{ Tube Surface } & 11 & CAHIT1 & $\begin{array}{l}\text { 1" up center tube, facing upstream (failed, ND1 } \\
\text { and ND2) }\end{array}$ \\
\hline & 12 & CAHIT2 & $\begin{array}{l}5 " \text { up center tube, facing upstream (failed, ND1 } \\
\text { and ND2) }\end{array}$ \\
\hline & 13 & CAHIT3 & $8 "$ up center tube, facing upstream \\
\hline & 14 & CAHIT4 & 5" up center tube, facing to side (failed, ND2) \\
\hline & 15 & CAHIT5 & 5" up center tube, facing downstream \\
\hline Header Shell & 16 & CAHTC4 & Next to shell on outside, between return air pipes \\
\hline
\end{tabular}

${ }^{1}$ Thermocouple locations are illustrated in Exhibit 2.2-47. 


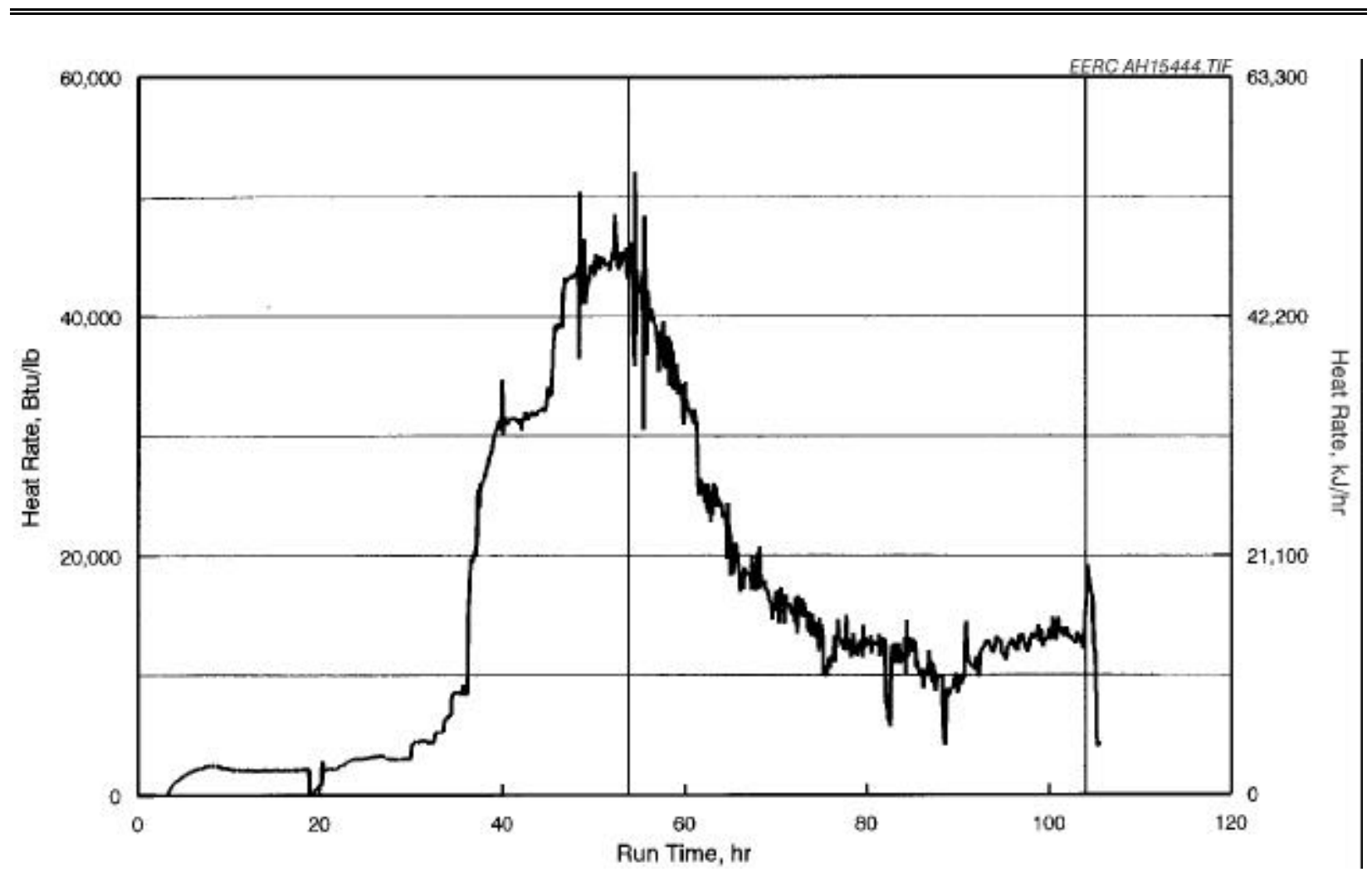

Exhibit 2.2-49

CAH Heat Recovery versus Run Time for the April Test Period

When lignite firing (Coal Creek-Falkirk) began, surface temperatures initially decreased at a rate of nominally $15^{\circ} \mathrm{F} / \mathrm{hr}\left(8^{\circ} \mathrm{C} / \mathrm{hr}\right)$ over several hours as ash deposits developed on the surface of the tubes. After nearly $40 \mathrm{hr}$ of lignite firing, that rate dropped to about $9^{\circ} \mathrm{F} / \mathrm{hr}\left(5^{\circ} \mathrm{C} / \mathrm{hr}\right)$. It must be noted that $\mathrm{CA}$ flow rates were also decreasing over these time frames in an attempt to maintain a relatively constant $\mathrm{CA}$ exit temperature. The minimum $\mathrm{CA}$ flow rate through the $\mathrm{CAH}$ tube bank was $60 \mathrm{scfm}\left(1.7 \mathrm{~m}^{3} / \mathrm{min}\right)$. Stable temperatures were observed during natural gas-fired periods prior to initiating lignite feed at about Run Hour 54. As ash deposits developed on the tube surfaces, heat recovery from the CAH tube bank decreased from roughly 45,000 Btu/hr $(47,475 \mathrm{~kJ} / \mathrm{hr})$ to $12,500 \mathrm{Btu} / \mathrm{hr}(13,188 \mathrm{~kJ} / \mathrm{hr})$.

EERC personnel did not attempt to clean the CAH tube bank during the April test to facilitate the development of ash deposits for characterization. If CAH tube bank cleaning had occurred, heat recovery would have marginally improved. However, based on previous operating experience, heat recovery would have increased beyond 20,000 Btu/hr $(21,100 \mathrm{~kJ} / \mathrm{hr})$ and then decreased to a level approaching 10,000 Btu/hr (10,550 kJ/hr). CAH tube bank plugging was not a problem. The deposits that formed were limited to the leading and trailing edges of the tubes. No deposits were observed bridging the flue gas paths between the tubes.

Exhibit 2.2-50 is a photograph of ash deposits on the surface of the tubes following the April test. The photograph shows that all five of the ceramic tubes in the tube bank were damaged when the tube bank was removed from the $\mathrm{CAH}$ duct. These damaged tubes were repaired prior to the April test using a castable refractory. In general, the ash deposits resulting from Coal Creek-Falkirk lignite firing were somewhat stronger than those observed following the Rochelle 
subbituminous coal test and weaker than those observed following the Illinois No. 6 bituminous coal test. Deposit strength is a function of ash chemistry, particle size, and temperature history. The relative strength of the deposits was indicated by the fact that portions of the deposits on the leading edge of the tubes fell from the tube surface when the CAH tube bank was removed from the duct. Because of the weak nature of the deposits, they were difficult to remove from the tubes intact. Note, however, that similar deposits formed in full-scale boilers when this lignite is burned can become very hard through in situ sulfation over longer periods of time.

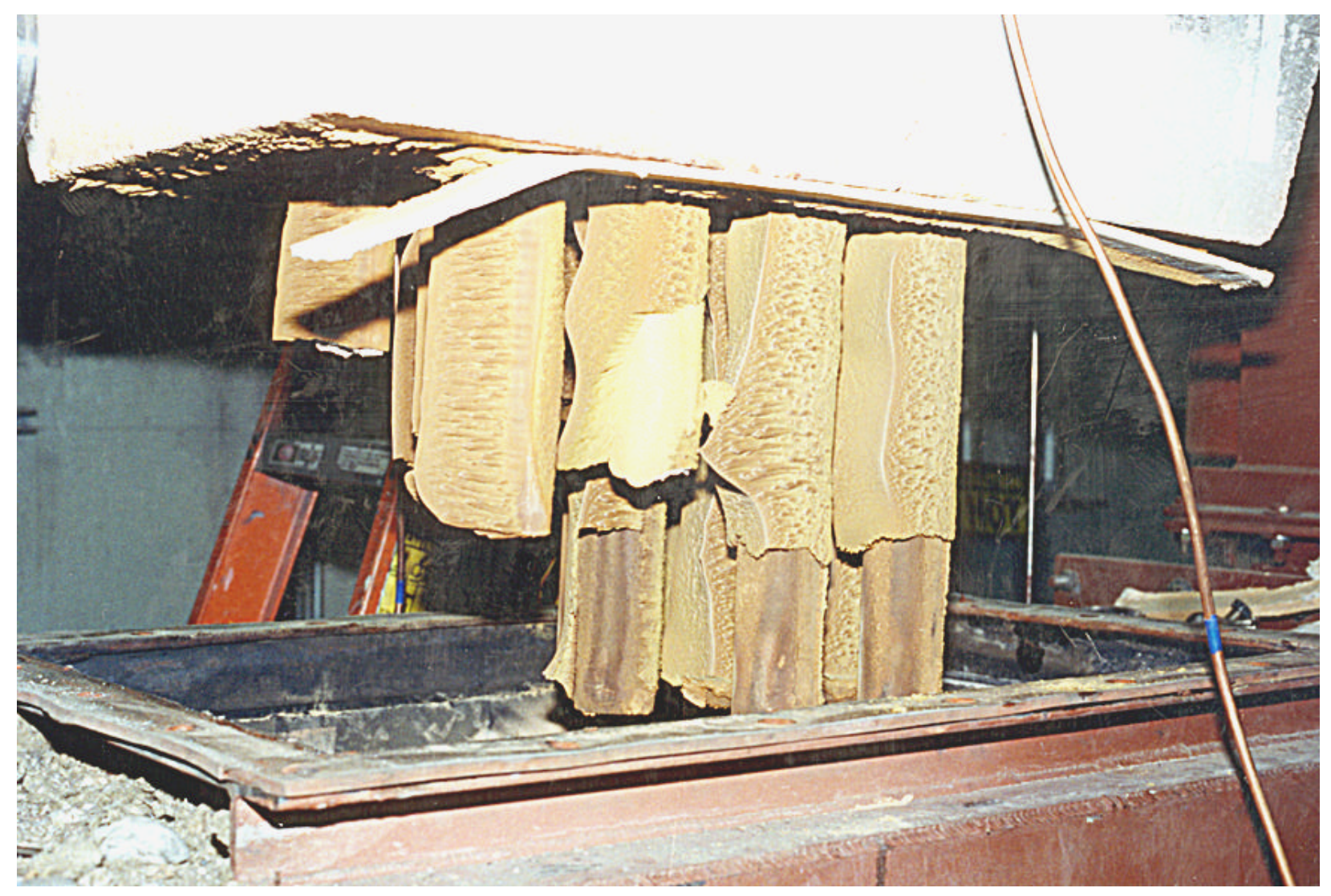

\section{Exhibit 2.2-50 \\ Photograph of Ash Deposits on the CAH Tubes Following the April Test Period Firing Coal Creek-Falkirk Lignite}

The total weight of the deposits collected from the CAH tubes and duct was $45.5 \mathrm{lb}(20.6 \mathrm{~kg})$. The total weight of the deposits collected from the CAH tubes was $12.1 \mathrm{lb}(5.5 \mathrm{~kg})$. An ash deposition rate can be expressed in many ways for the CAH tube bank. On a mass per unit time basis, the ash deposition rate for this Coal Creek-Falkirk lignite-fired test would be $0.24 \mathrm{lb} / \mathrm{hr}$ $(109 \mathrm{~g} / \mathrm{hr})$ of lignite firing. Incorporating the surface area of the tube bank $\left(6.28 \mathrm{ft}^{2}\right.$ or $\left.0.58 \mathrm{~m}^{2}\right)$ results in a value of $0.038 \mathrm{lb} / \mathrm{hr}_{-} \mathrm{ft}^{2}\left(188 \mathrm{~g} / \mathrm{hr}-\mathrm{m}^{2}\right)$. On a lignite-firing-rate basis, the CAH ash deposition rate would be $0.092 \mathrm{lb} / \mathrm{MMBtu}\left(40.4 \mathrm{~g} / 10^{6} \mathrm{~kJ}\right)$. An additional $33.4 \mathrm{lb}(15.2 \mathrm{~kg})$ of ash was recovered from the horizontal duct in which the CAH tube bank is located.

The compositions of the fly ash and deposits collected from the SFS after the April test are compared to the composition of the coal ash in Exhibit 2.2-51. 


\begin{tabular}{|c|c|c|c|c|c|}
\hline \multicolumn{6}{|c|}{$\begin{array}{c}\text { Exhibit 2.2-51 } \\
\text { XRF Analysis Results for Selected Coal Creek Lignite, Slag, and Ash Samples } \\
\text { Collected During and After the April Test Period } \\
\text { (normalized, sulfur-free oxide wt\%) }\end{array}$} \\
\hline Oxides & $\begin{array}{l}\text { Coal Creek } \\
\text { Lignite } \\
\text { Composite }\end{array}$ & $\begin{array}{l}\text { Slag Pot - } \\
\text { Black Slag }\end{array}$ & $\begin{array}{l}\text { CAH Leading } \\
\text { Edge Outer } \\
\text { Deposit }\end{array}$ & $\begin{array}{l}\text { CAH Inner } \\
\text { Layer } \\
\text { Deposit }\end{array}$ & $\begin{array}{c}\text { Baghouse } \\
\text { Ash }\end{array}$ \\
\hline $\mathrm{SiO}_{2}$ & 42.2 & 42.1 & 40.8 & 31.1 & 38.6 \\
\hline $\mathrm{Al}_{2} \mathrm{O}_{3}$ & 14.3 & 22.4 & 14.7 & 14.5 & 13.2 \\
\hline $\mathrm{Fe}_{2} \mathrm{O}_{3}$ & 9.6 & 9.2 & 9.5 & 11.2 & 9.0 \\
\hline $\mathrm{TiO}_{2}$ & 0.6 & 0.7 & 0.6 & 0.7 & 0.6 \\
\hline $\mathrm{P}_{2} \mathrm{O}_{5}$ & 0.3 & 0.2 & 0.4 & 0.5 & 0.5 \\
\hline $\mathrm{CaO}$ & 20.2 & 16.4 & 21.1 & 28.0 & 22.2 \\
\hline $\mathrm{MgO}$ & 7.8 & 4.7 & 6.5 & 6.9 & 6.7 \\
\hline $\mathrm{Na}_{2} \mathrm{O}$ & 3.4 & 3.1 & 4.6 & 4.8 & 6.1 \\
\hline $\mathrm{K}_{2} \mathrm{O}$ & 1.6 & 1.3 & 1.8 & 2.3 & 3.0 \\
\hline $\mathrm{SO}_{3}{ }^{1}$ & 16.0 & 0.1 & 5.8 & 28.7 & 17.0 \\
\hline Closure $^{2}$ & 99.2 & 88.9 & 96.4 & 95.8 & 98.5 \\
\hline
\end{tabular}

${ }^{1}$ Normalized with other oxides.

${ }^{2}$ Closure before normalizing.

A fairly low data closure was measured for the slag sample. Usually, this implies high concentrations of elements that are not included in the analysis matrix, but in this case only very small peaks for other elements heavier than carbon were detected. Also, thermal analysis showed that the low closure is not due to dissolved carbon. Instead, the low data closure may be caused by difficulty in grinding the hard slag to a small enough particle-size distribution. Samples composed of relatively large particles often exhibit lower closure rates. Even so, however, the lower closure rate should not affect the relative quantities of the major elements for that sample.

A comparison of the coal ash composition with that of the slag captured in the slag pot indicates that the slag tends to be enriched in alumina and depleted in calcia and magnesia relative to the coal ash. The alumina enrichment is undoubtedly due to dissolution of the new refractory patches by the lignite slag. The reduced levels of calcia and magnesia are partially caused by dilution with the excess alumina, but also indicate that those two oxides were concentrated in the smaller ash particles which are less likely to impact furnace or slag screen surfaces than larger particles. Their concentration in the smaller particles most likely occurred because these elements tend to be largely present in the lignite as salts of carboxylic acids and, as such, tend to vaporize during combustion, immediately recondensing as very fine particulates. Titration of the dissolved 
slag with a vanadium solution (Wilson, 1960) showed that approximately $25 \%$ of the iron in the slag was in the ferrous $\left(\mathrm{Fe}^{2+}\right)$ state.

In contrast to the slag composition, the bulk of the ash deposits collected on the upstream sides of the CAH tubes is quite similar to that of the coal ash. However, the thin inner layers of the deposits, those next to the tube which may consequently corrode the alloy, are depleted in silica and enriched in calcia and soda relative to the coal ash or the slag. They are also highly sulfated. The baghouse ash is, like the bulk of the CAH deposits, more similar to the composition of the coal ash, except for soda, which is highly enriched in the baghouse samples. It is also highly sulfated material.

Exhibits 2.2-52 through 2.2-54 summarize CAH tube bank surface and flue gas temperatures, CA temperatures, and CA flow rate data for the June test period (Center lignite). While natural gas was fired, heat recovery from the $\mathrm{CAH}$ tube bank was $48,750 \mathrm{Btu} / \mathrm{hr}(51,431 \mathrm{~kJ} / \mathrm{hr})$ for a CA flow rate of $150 \mathrm{scfm}\left(4.2 \mathrm{~m}^{3} / \mathrm{min}\right)$, an inlet CA temperature of $1040^{\circ} \mathrm{F}\left(560^{\circ} \mathrm{C}\right)$, an outlet CA temperature of $1206^{\circ} \mathrm{F}\left(653^{\circ} \mathrm{C}\right)$, and a flue gas temperature of $1800^{\circ} \mathrm{F}\left(983^{\circ} \mathrm{C}\right)$ entering the $\mathrm{CAH}$ tube bank. Exhibit 2.2-55 presents heat recovery in the $\mathrm{CAH}$ as a function of run time for the June test period.

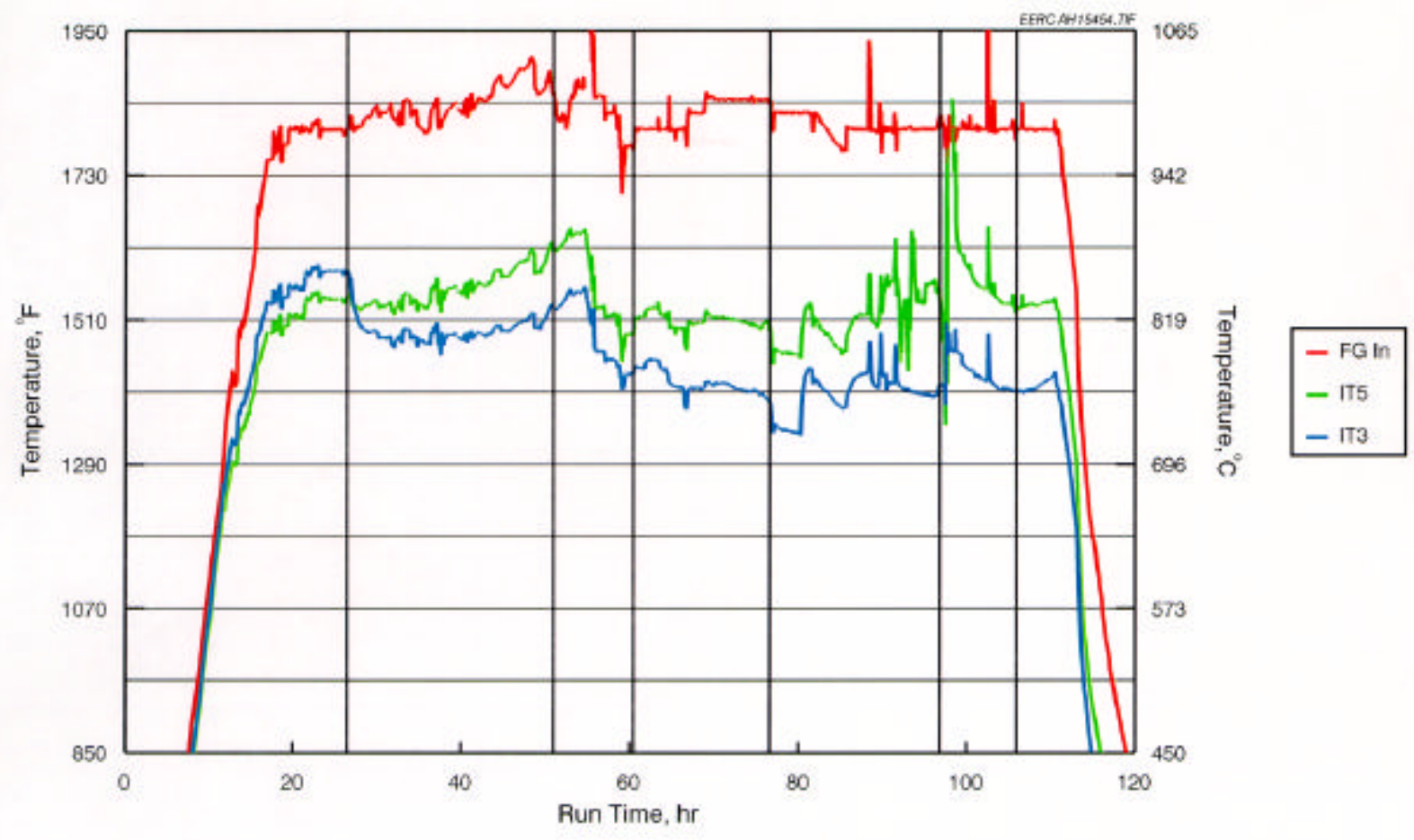

Exhibit 2.2-52

CAH Tube Surface an Flue Gas Temperatures versus Run Time for the June Test Period 


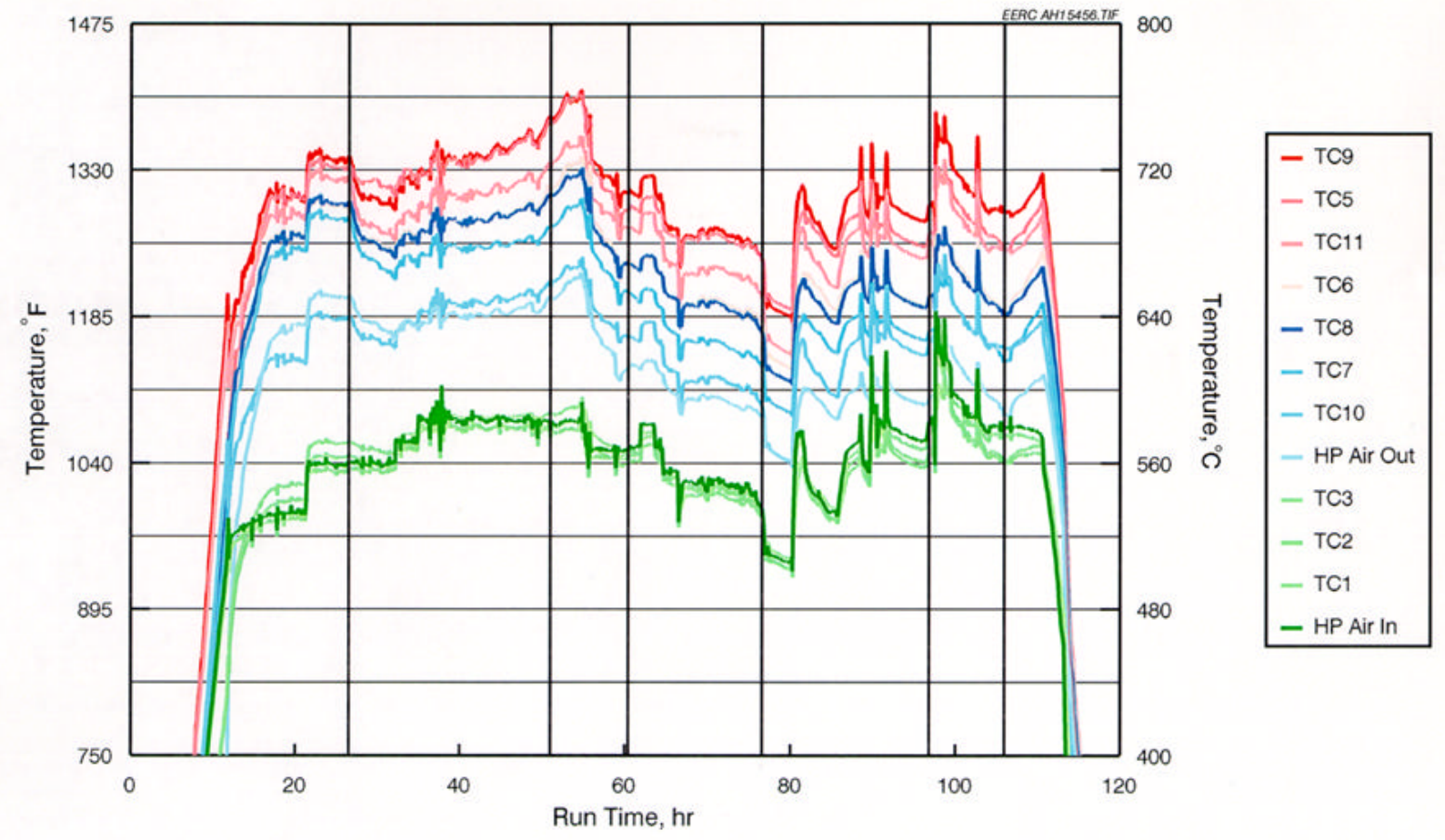

Exhibit 2.2-53

CAH Cooling Air Temperatures versus Run Time for the June Test Period 


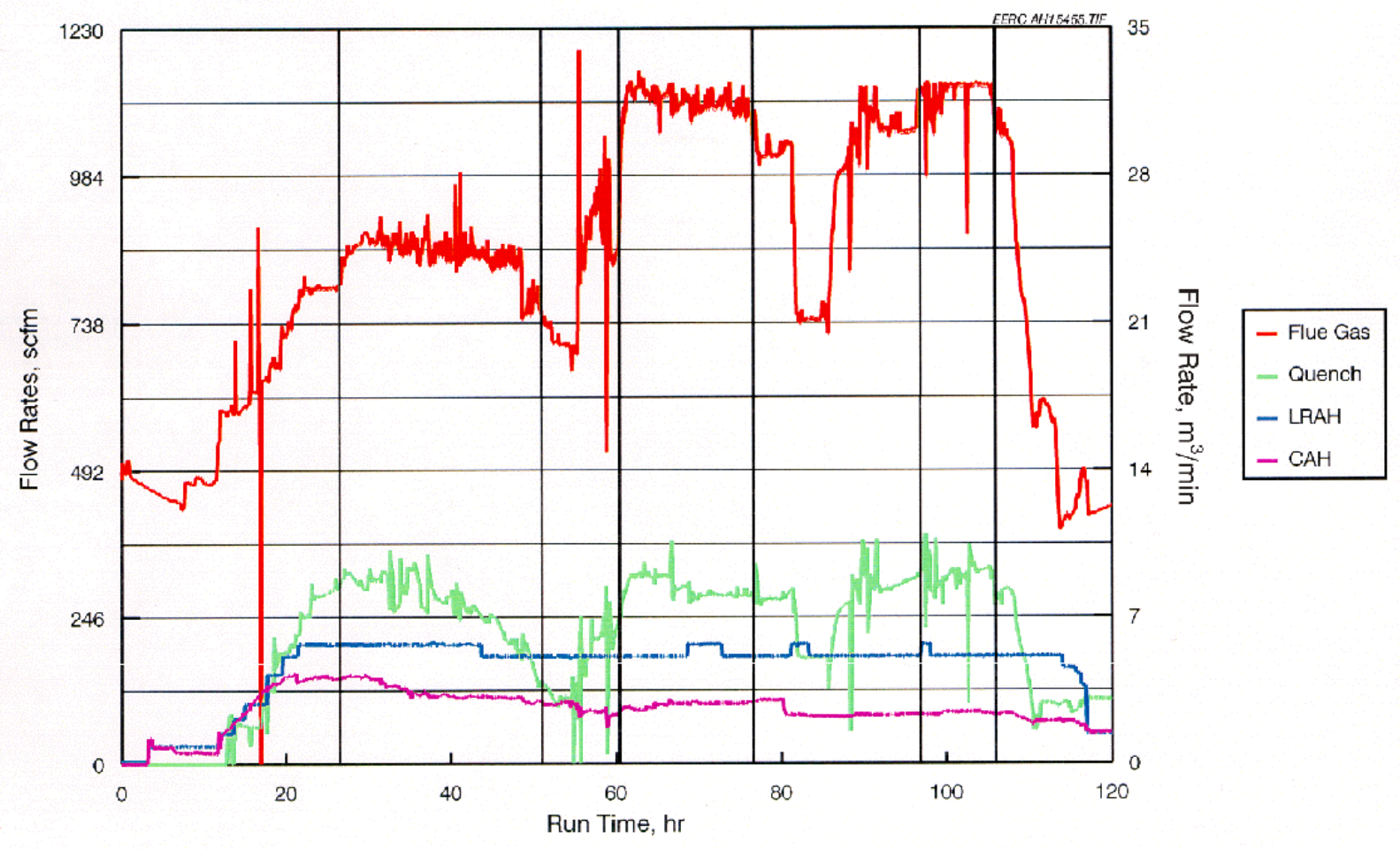

Exhibit 2.2-54

CAH Cooling Air, LRAH Cooling Air, Quench Gas, and Flue Gas Flow Rates versus Run Time for the June Test Period 


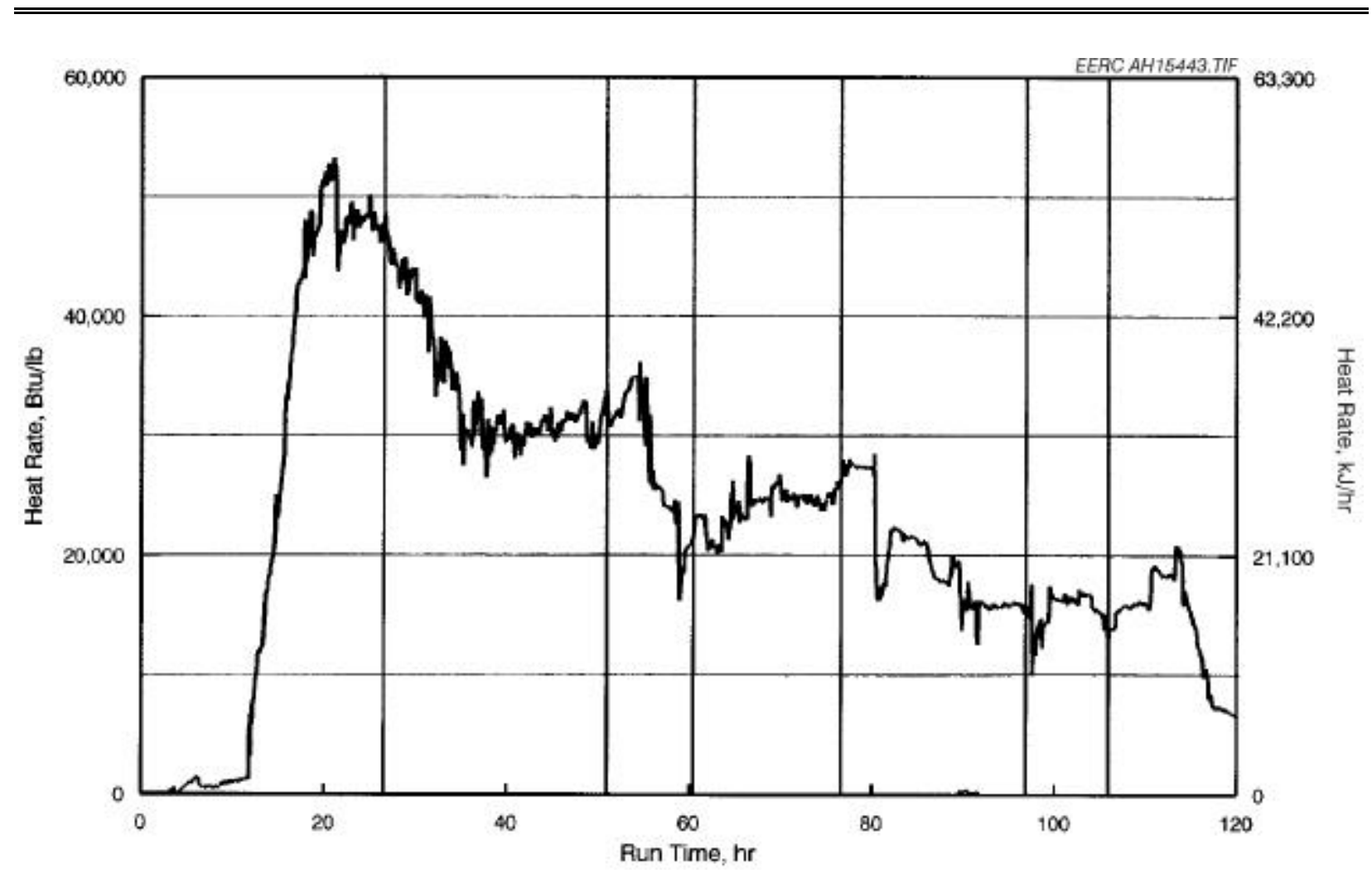

Exhibit 2.2-55

CAH Heat Recovery versus Run Time for the June Test Period

When firing of the Center lignite began during the June test, CAH tube surface temperatures initially decreased at a rate of nominally $42^{\circ} \mathrm{F} / \mathrm{hr}\left(23^{\circ} \mathrm{C} / \mathrm{hr}\right)$ over roughly 2 hours as ash deposits developed on the surface of the tubes. The CAH CA flow rate was nominally $150 \mathrm{scfm}(4.25$ $\left.\mathrm{m}^{3} / \mathrm{min}\right)$. After about $20 \mathrm{hr}$ of lignite firing, CAH temperatures and heat recovery $(31,000 \mathrm{Btu} / \mathrm{hr}$ or $32,705 \mathrm{~kJ} / \mathrm{hr})$ stabilized as a result of rising flue gas temperature $\left(1910^{\circ} \mathrm{F}\right.$ or $\left.1044^{\circ} \mathrm{C}\right)$ in the $\mathrm{CAH}$ duct and reduced $\mathrm{CA}$ flow rate. Once flue gas temperature control in the CAH duct was regained, tube surface temperature decreased at a rate of roughly $5^{\circ} \mathrm{F} / \mathrm{hr}\left(3^{\circ} \mathrm{C} / \mathrm{hr}\right)$. It must be noted that CA flow rates were stable during this time frame at $100 \mathrm{scfm}(2.83 \mathrm{~m} / \mathrm{min})$. The minimum CAH CA flow rate was $80 \mathrm{scfm}\left(2.3 \mathrm{~m}^{3} / \mathrm{min}\right)$. At CA flow rate of $100 \mathrm{scfm}(2.83$ $\left.\mathrm{m}^{3} / \mathrm{min}\right)$ and a $\mathrm{CAH}$ flue gas temperature of $1800^{\circ} \mathrm{F}\left(982^{\circ} \mathrm{C}\right)$, CA temperature was increased from 1019 to $1102^{\circ} \mathrm{F}\left(548\right.$ to $\left.595^{\circ} \mathrm{C}\right)$ through the $\mathrm{CAH}$ tube bank. The heat recovery at these conditions was $25,200 \mathrm{Btu} / \mathrm{hr}(26,586 \mathrm{~kJ} / \mathrm{hr})$.

Again, EERC personnel did not attempt to clean the CAH tube bank during the June test period to facilitate the development of ash deposits for characterization. If the CAH tube bank had been cleaned, heat recovery would have marginally improved. Based on previous operating experience, heat recovery would have increased and then decreased to a level of $<20,000 \mathrm{Btu} / \mathrm{hr}$ $(<21,100 \mathrm{~kJ} / \mathrm{hr})$. CAH tube bank plugging was not a problem. The deposits that formed were limited to the leading and trailing edges of the tubes. No deposits were observed bridging the flue gas paths between the tubes. 
Exhibit 2.2-56 is a photograph of ash deposits on the surface of the tubes following the June test period. The photograph shows only the deposits on the air-cooled metal tubes. The five uncooled ceramic tubes are not present in the photograph because they were replaced with five uncooled stainless steel tubes prior to the June test period. Replacement of the ceramic tubes was necessary because of the repeated damage observed in February, March, and April. Exhibit 2.2-57 presents two photographs of the five uncooled stainless tubes. The upper photograph shows the tubes installed in the CAH duct after the June test, and the lower photograph shows the tubes after the ash deposits were removed.

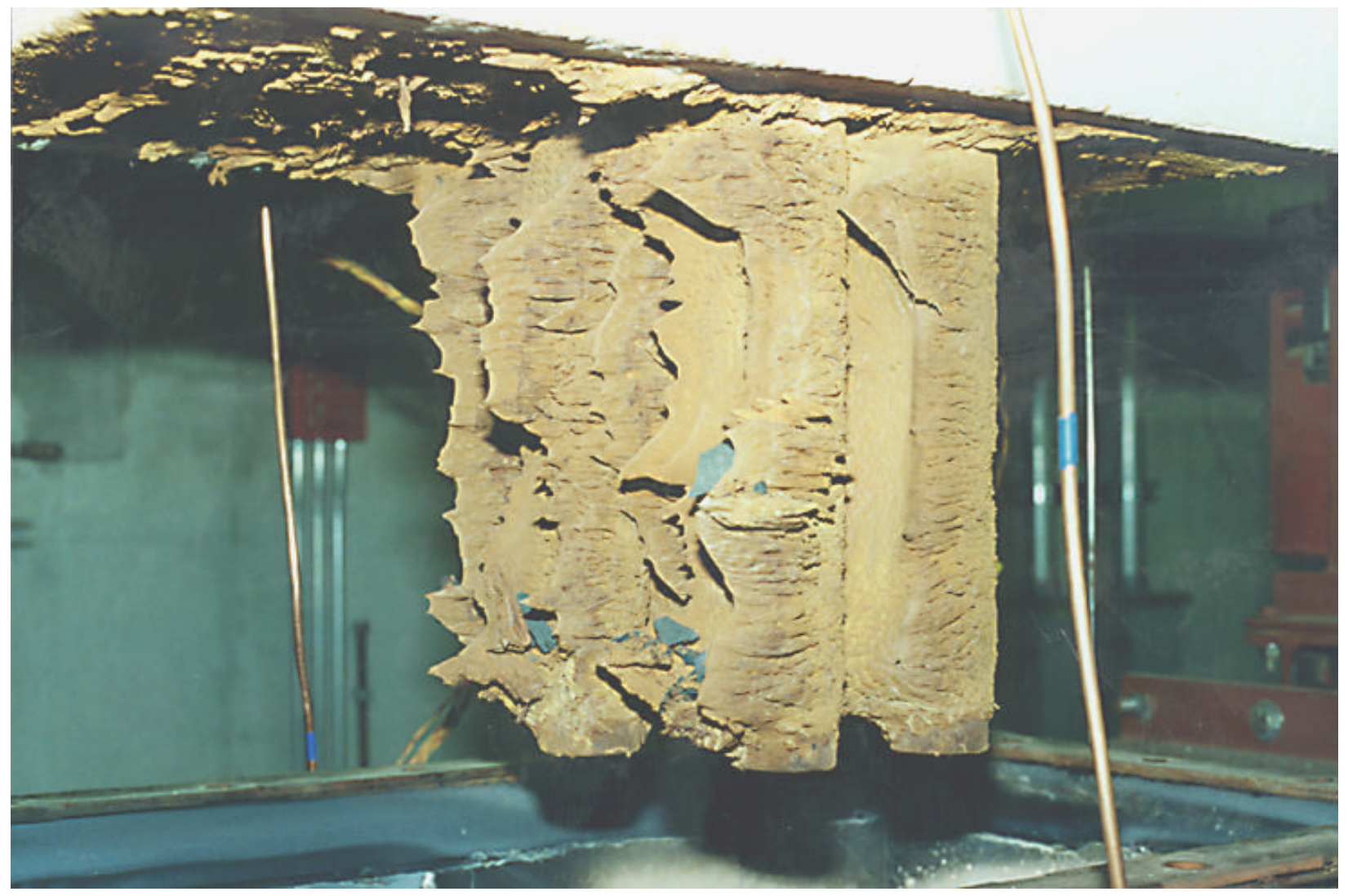

Exhibit 2.2-56

Photograph of Ash Deposits on the CAH Tubes Following the June Test Period Firing Center Lignite 


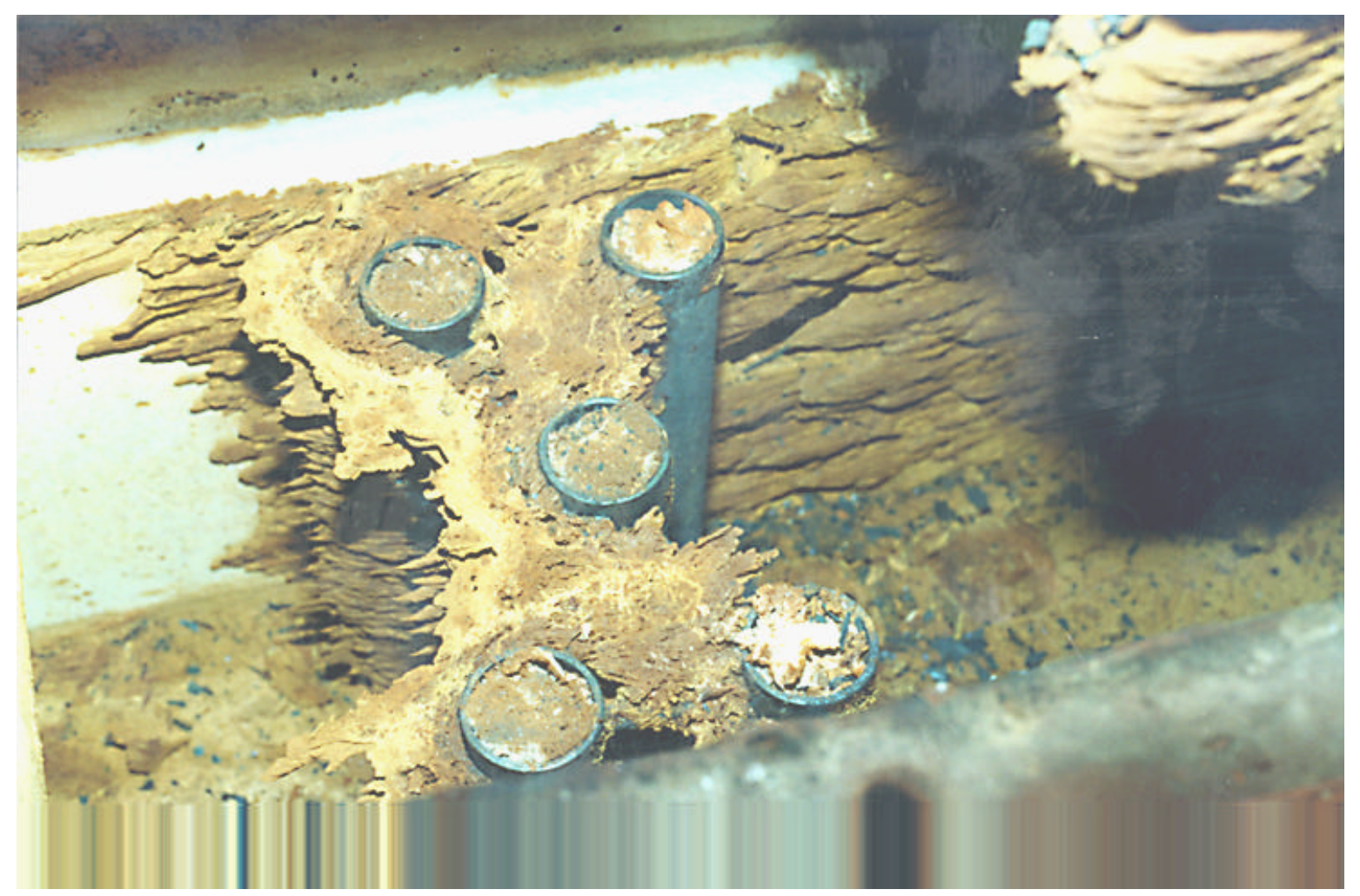

(a)

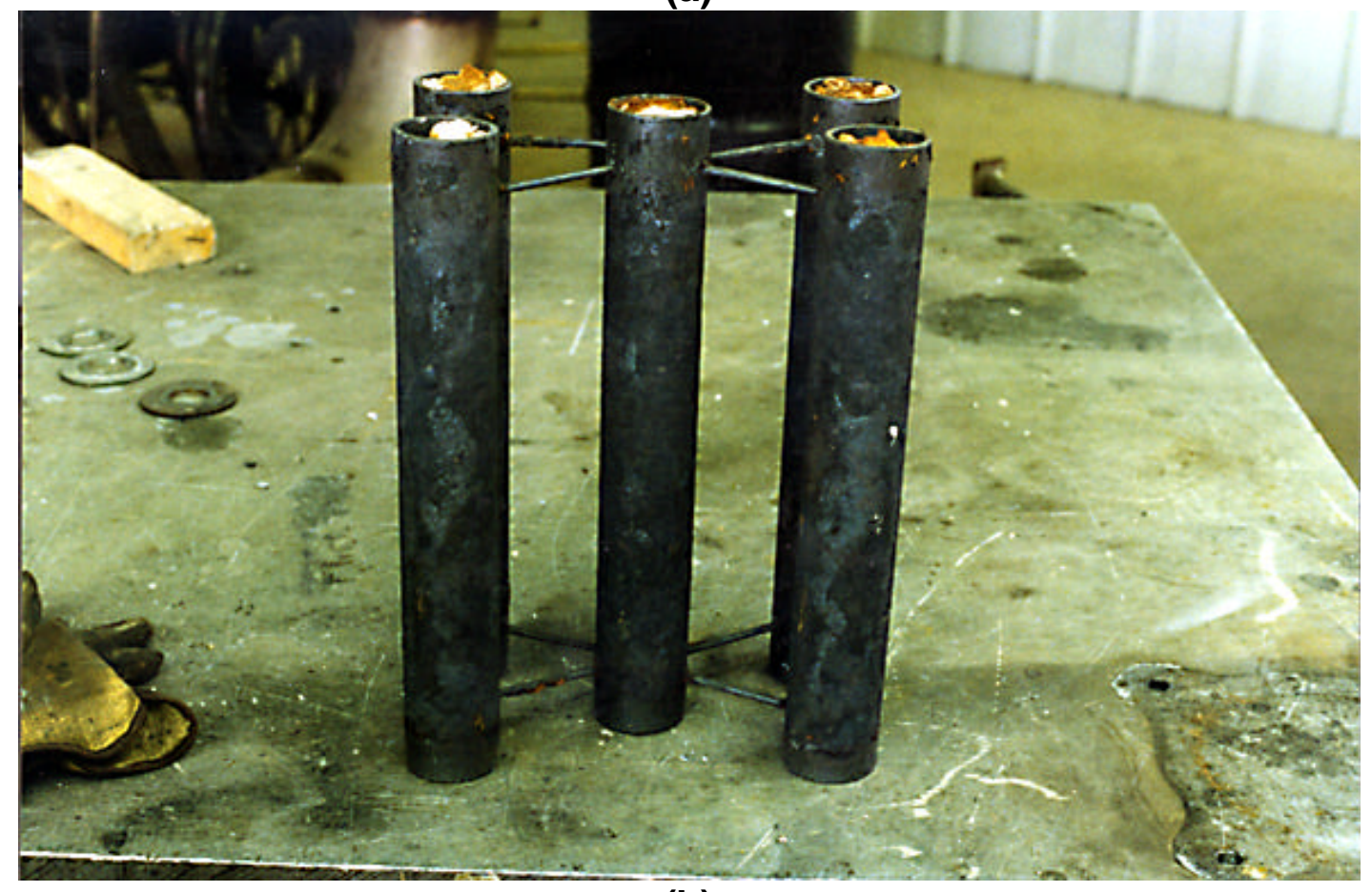

(b)

Exhibit 2.2-57

Photographs of Uncooled Stainless Steel Tubes Used in the CAH Tube Bank to Replace Damaged Ceramic Tubes 
In general, the ash deposits resulting from the Center lignite test were stronger than those observed following the Rochelle subbituminous coal and the Coal Creek-Falkirk lignite tests. Deposit strength was comparable to the Illinois No. 6 bituminous coal test. Detailed deposit characterization should indicate whether deposit strength in this case was simply a function of ash chemistry or if flue gas temperature excursions above $1800^{\circ} \mathrm{F}\left(982^{\circ} \mathrm{C}\right)$ were also a contributing factor. The total weight of the deposits collected from the CAH tubes and duct was $37.3 \mathrm{lb}$ (16.9 $\mathrm{kg})$. The total weight of the deposits collected from the CAH tubes was $21.6 \mathrm{lb}(9.8 \mathrm{~kg})$. On a mass per unit time basis, the ash deposition rate for this Coal Creek-Falkirk lignite-fired test would be $0.43 \mathrm{lb} / \mathrm{hr}(195 \mathrm{~g} / \mathrm{hr})$ of lignite firing. Incorporating the surface area of the tube bank $\left(6.28 \mathrm{ft}^{2}\right.$ or $\left.0.58 \mathrm{~m}^{2}\right)$ results in a value of $0.068 \mathrm{lb} / \mathrm{hr}-\mathrm{ft}^{2}\left(336 \mathrm{~g} / \mathrm{hr}-\mathrm{m}^{2}\right)$. On a lignite-firing rate basis, the $\mathrm{CAH}$ ash deposition rate would be $0.169 \mathrm{lb} / \mathrm{MMBtu}\left(73.6 \mathrm{~g} / 10^{6} \mathrm{~kJ}\right)$. An additional 15.7 $\mathrm{lb}(7.1 \mathrm{~kg})$ of ash was recovered from the horizontal duct in which the CAH tube bank is located.

The compositions of the deposits and baghouse ash collected from the SFS after the June test are compared to the coal ash in Exhibit 2.2-58. 
Exhibit 2.2-58

XRF Analysis Results for Selected Center Lignite, Slag, and Ash Samples Collected During and After the June Test Period (normalized, sulfur-free oxide wt\%)

\begin{tabular}{lccccc}
\hline Oxides & $\begin{array}{c}\text { Center } \\
\text { Lignite } \\
\text { Composite }\end{array}$ & $\begin{array}{c}\text { Slag } \\
\text { Pot } \\
\text { Slag }\end{array}$ & $\begin{array}{c}\text { CAH Leading } \\
\text { Edge Outer } \\
\text { Deposit }\end{array}$ & $\begin{array}{c}\text { CAH Inner } \\
\text { Layer } \\
\text { Deposit }\end{array}$ & $\begin{array}{c}\text { Baghouse } \\
\text { Ash }\end{array}$ \\
\hline $\mathrm{SiO}_{2}$ & 15.1 & 22.3 & 16.6 & 13.5 & 8.3 \\
$\mathrm{Al}_{2} \mathrm{O}_{3}$ & 11.7 & 22.7 & 10.0 & 9.7 & 5.5 \\
$\mathrm{Fe}_{2} \mathrm{O}_{3}$ & 17.9 & 17.4 & 15.1 & 12.9 & 7.6 \\
$\mathrm{TiO}_{2}$ & 0.3 & 0.4 & 0.4 & 0.3 & 0.1 \\
$\mathrm{P}_{2} \mathrm{O}_{5}$ & 0.1 & 0.1 & 0.3 & 0.4 & 0.2 \\
$\mathrm{CaO}$ & 28.8 & 28.2 & 38.3 & 38.5 & 17.3 \\
$\mathrm{MgO}$ & 9.9 & 5.5 & 8.0 & 7.7 & 2.6 \\
$\mathrm{Na}_{2} \mathrm{O}$ & 15.9 & 3.2 & 10.6 & 16.3 & 55.4 \\
$\mathrm{~K}_{2} \mathrm{O}$ & 0.2 & 0.0 & 0.7 & 0.7 & 3.1 \\
& & & & & \\
$\mathrm{SO}_{3}{ }^{1}$ & 26.2 & 0.0 & 21.8 & 37.7 & 44.4 \\
$\mathrm{Closure}^{2}$ & 97.5 & 96.5 & 97.8 & 96.2 & 99.2 \\
\hline
\end{tabular}

${ }^{1}$ Normalized with other oxides.

${ }^{2}$ Closure before normalizing.

As was true for the first lignite test, the slag collected in the slag pot was enriched in alumina probably due to dissolution of the new refractory patches. However, in contrast to the first test, the slag from the second lignite was much more enriched in silica and depleted in soda as compared to the coal ash. The higher silica and alumina concentrations and lower soda concentrations in the slag raised the fluid temperature in an oxidizing atmosphere from $2430^{\circ} \mathrm{F}$ $\left(1330^{\circ} \mathrm{C}\right)$ measured for the coal ash to $2570^{\circ} \mathrm{F}\left(1410^{\circ} \mathrm{C}\right)$ for the slag collected from the slag pot. Slag that was frozen in large bubbled masses in the slag screen had extensively dissolved the refractory so that it contained $50 \%$ alumina. After dissolving that high level of alumina, its viscosity and liquidus temperatures increased substantially so that it could no longer flow out of the screen section. The alumina-rich slag had a softening point over the limit of the ash fusion furnace $\left(2800^{\circ} \mathrm{F}\left[1540^{\circ} \mathrm{C}\right]\right)$. Crystalline phases identified in the slag screen slag consisted of primarily magnesium aluminate spinel $\left(\mathrm{MgAl}_{2} \mathrm{O}_{4}\right)$ and a high-alumina calcium aluminate known as Hibonite $\left(\mathrm{CaAl}_{12} \mathrm{O}_{19}\right)$. 
In contrast to the slag deposits, the outer layers of the deposits collected on the upstream sides of the $\mathrm{CAH}$ tubes contained silica and alumina levels very similar to those in the Center coal ash. They were also enriched in calcia and depleted in soda relative to the coal ash. They did, however, contain much more calcia and soda and were much more sulfated than those from the first lignite test, which is probably why these deposits were harder than those from the first lignite. The inner layers of the $\mathrm{CAH}$ deposits, those next to the alloy tubes which would, therefore, be responsible for corroding the tubes, were also enriched in calcia relative to the coal ash and contained even more soda than the outer deposits. They were also much more sulfated than the outer deposits. The baghouse ash was composed primarily of sodium sulfate particles, because it vaporizes at coal combustion temperatures then condenses as submicron particulates at temperatures below its dewpoint. The very small size of the particles causes them to stay entrained in the flue gas and to not significantly impact on SFS surfaces. Since much of the rest of the ash is removed by impaction, the flue gas reaching the baghouse is, therefore, highly enriched in the submicron soda-rich particulate.

Exhibit 2.2-59 is a photograph of the air-cooled CAH tubes. After the June test period, these tubes were removed from the tube bank, cleaned, and fins were added to the leading and trailing edges. The purpose of the fins is to increase heat transfer. The impact the fins will have on ash deposition is unknown. In addition, all of the $\mathrm{CAH}$ thermocouples were replaced during the reassembly process. Testing of the modified CAH tube bank will occur during the next test period scheduled for August. 


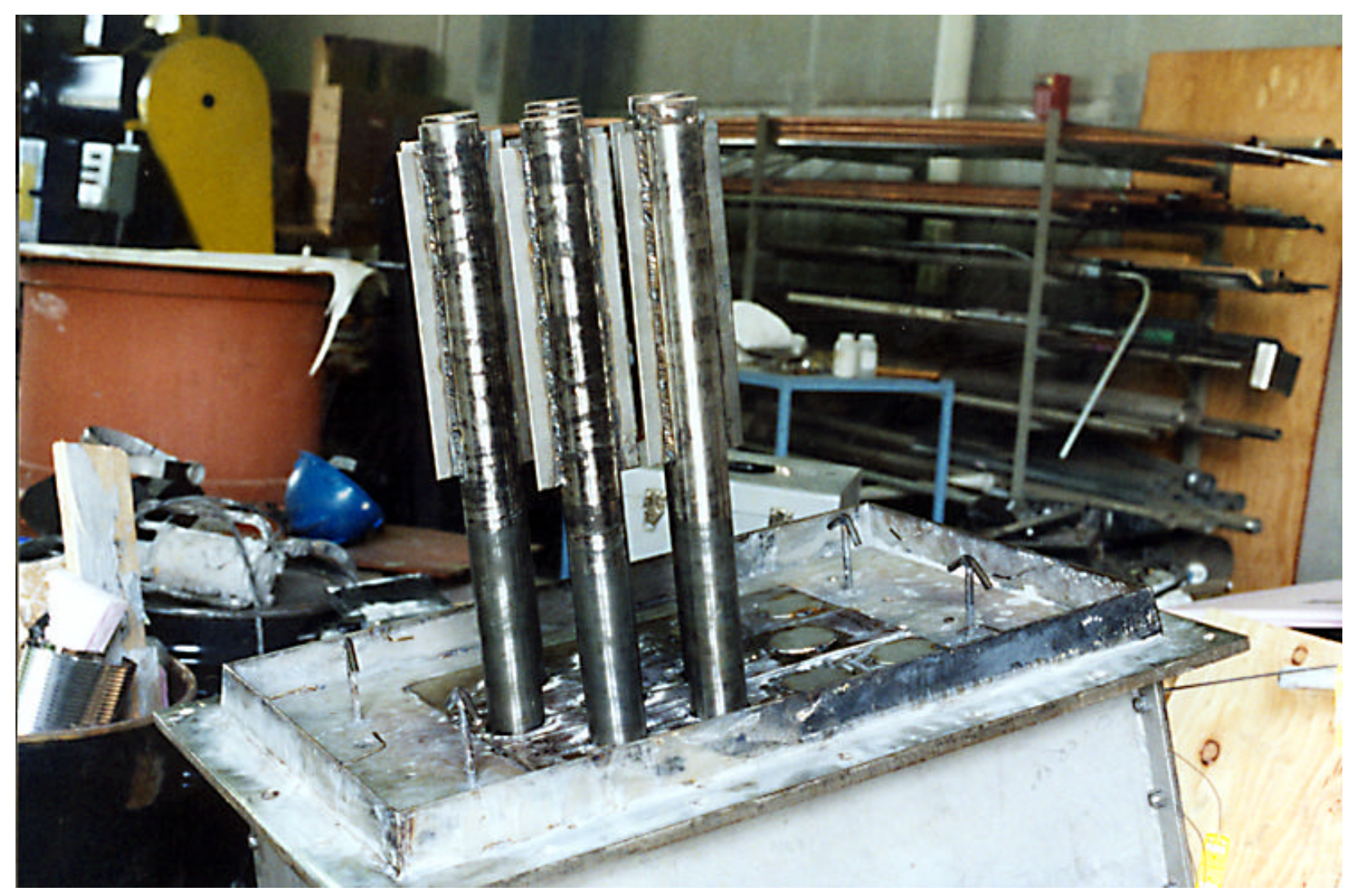

Exhibit 2.2-59

Photograph of the Modified CAH Tube Bank

\section{Testing of the LRAH Panel}

Initial shakedown and testing of the LRAH panel occurred in December 1997. Testing of the LRAH panel continued this past quarter, evaluating LRAH panel performance relative to heat transfer, tile and tube temperatures, and CA temperatures and flow rates while firing two lignite fuels. In general, the performance of the LRAH panel this past quarter was as anticipated, with no significant process problems.

The LRAH panel was thoroughly inspected following each week of operation this past quarter. After each test the tiles and bricks were intact, but all seven had one or more visible cracks on the surface. On the bottom support brick, large lower tile, and small upper and lower tiles, these cracks extended completely across the surface. Many of the cracks previously observed are no longer visible because of the slag/refractory layer on the surface of the tiles/bricks. As a result of LRAH panel damage observed following the March test period, the small and large upper tiles were replaced in April at the same time the SRAH panel was installed. Exhibit 2.2-60 is a photograph of the LRAH and SRAH panels in the furnace prior to the April test period. 


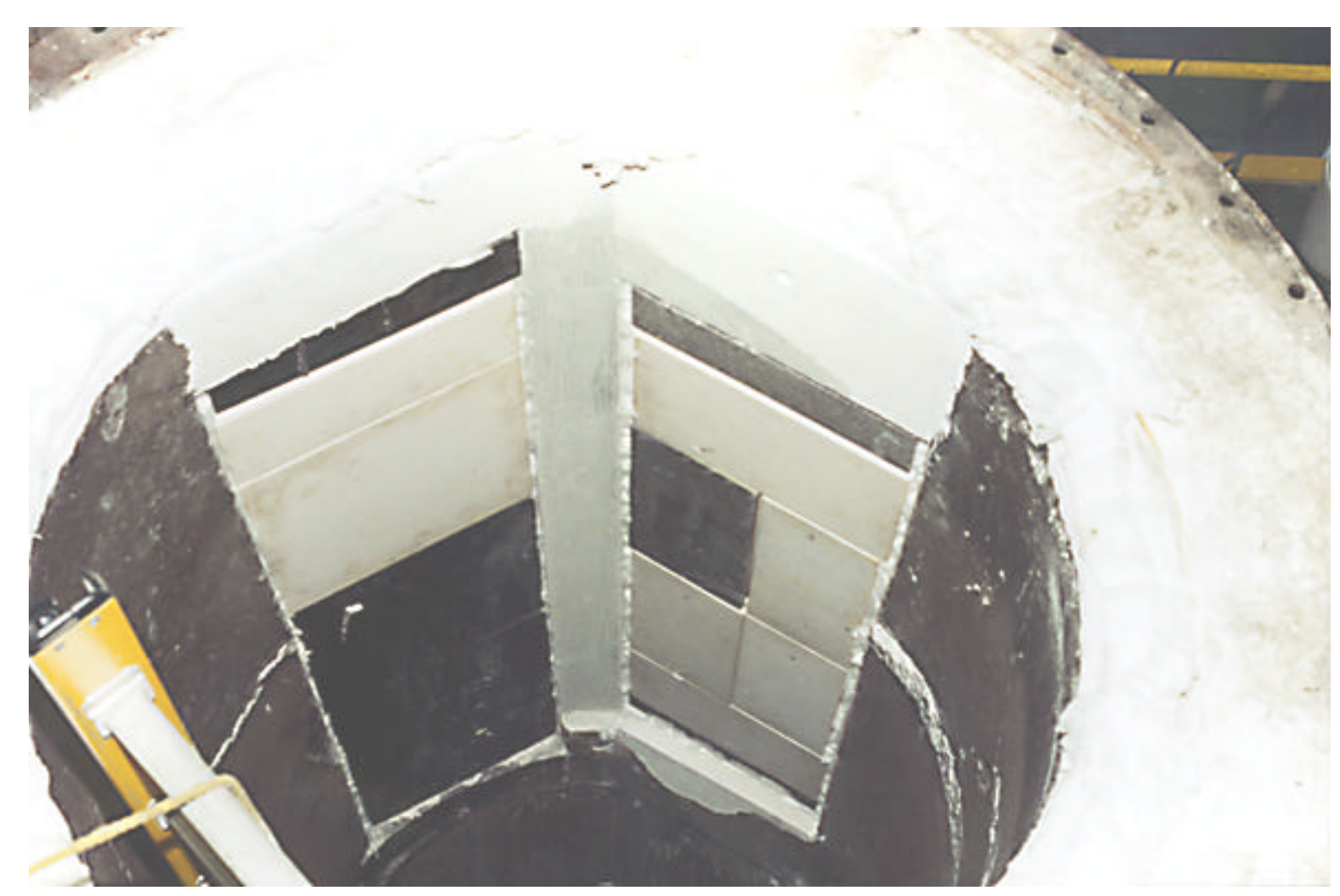

Exhibit 2.2-60

Photograph of the LRAH and SRAH Panels Prior to the April Test Period

Exhibit 2.2-61 shows the status of the tile/brick (LRAH panel) cracking after the June test. The LRAH panel has a fairly uniform layer of slag/refractory on the surface. This material is strongly attached and cannot be removed. All of the seams between tiles/bricks are filled with slag, but the slag is cracked in all of the seams except the seam between the small upper tile and large upper tile. There is one visible crack in the upper right corner of the top support brick. Three vertical cracks previously seen across the face of this brick are no longer visible. The small upper tile (replaced in April prior to the lignite tests) has a short vertical crack originating from the top edge but generally appears to be in good condition. 


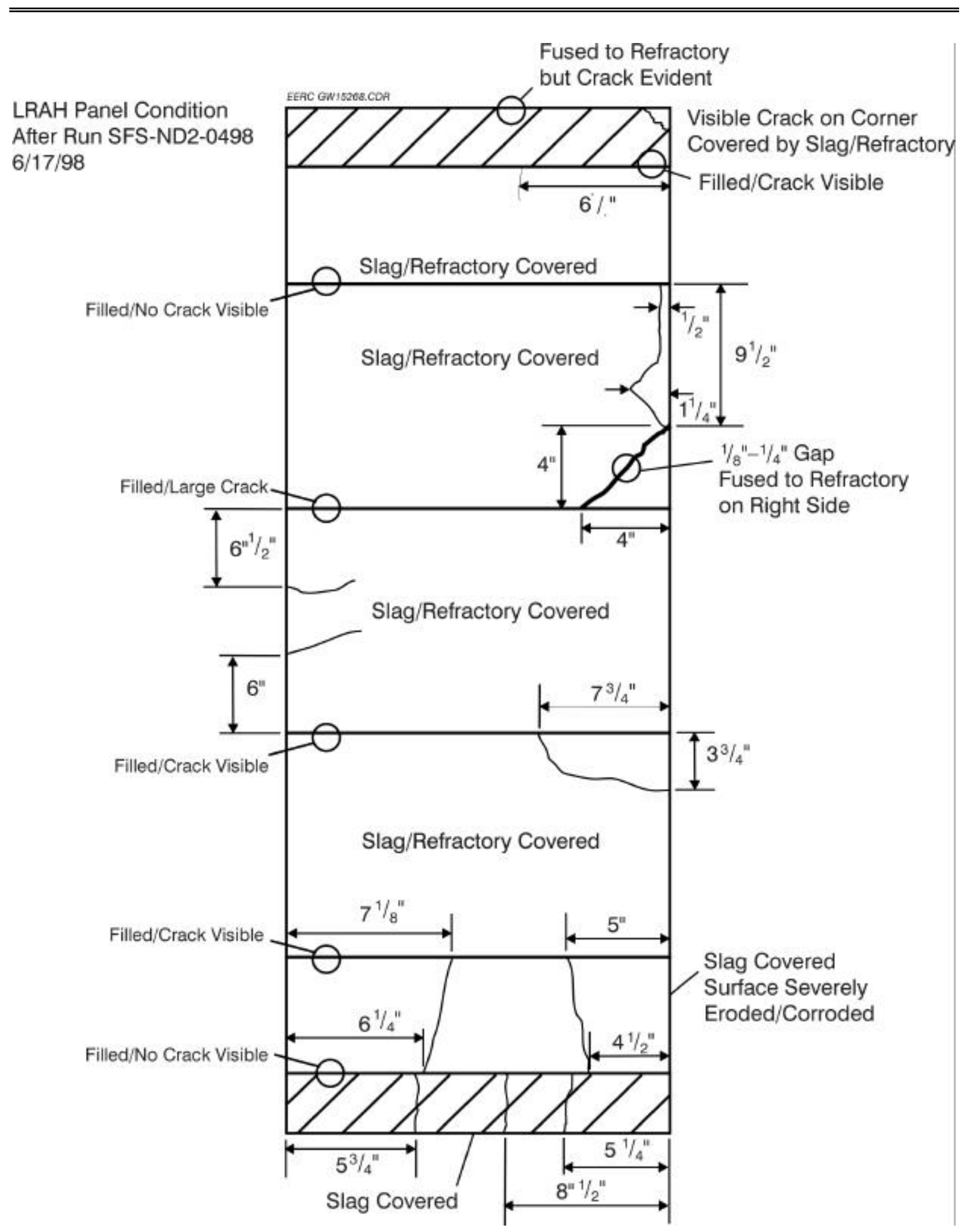

Exhibit 2.2-61

Illustration of Cracks Found in the Ceramic Tiles/Bricks of the LRAH Panel after Testing in June 1998 
The large upper tile (replaced in April prior to the lignite tests) has a vertical crack on the right edge, and the lower right corner has been broken, leaving a gap of 0.125 to 0.25 in.( 0.32 to $0.64 \mathrm{~cm})$. The vertical crack on the right edge does not appear to be a serious problem. However, the broken lower right corner could be a problem if it fails to close the gap or falls out upon furnace heating and refractory expansion. The broken piece of tile is fused to the refractory on the right side and bottom and is not expected to fall out. Upon further inspection, EERC and UTRC personnel agreed that the risks associated with completing another test period with the large upper tile in its current condition were small.

The large middle tile has two visible cracks, both originating on the left edge. None of these cracks appear to pose any particular problems. Other cracks previously visible on the large middle tile are covered with slag/refractory. The large lower tile has one visible crack starting at the top edge and progressing to the right edge. This crack does not appear to be serious at this time. Based on previous observations, this tile is believed to have the most extensive cracking. However, nearly all of the previously observed cracks have been covered with slag/refractory.

Two vertical cracks are evident through the face of the small lower tile. These cracks have been present since the LRAH panel was initially tested while firing natural gas in December 1997. The small lower tile is severely eroded/corroded as a result of slag flow over the surface but does not appear to be in any danger of failing. Other cracks previously visible in the surface of this tile are no longer visible because of slag coverage.

The small bottom support brick has three vertical cracks through its face. Two of these cracks are new since the March test period. Although all of the tiles/bricks show some degree of cracking that may be an indication of structural strength problems, there is no evidence at this time of any impending failure of any of the individual ceramic tiles/bricks. Therefore, there are no plans to replace any LRAH panel tiles/bricks before the next test period scheduled for August. The EERC will continue to document ceramic tile/brick cracking after each test is completed with the LRAH panel.

To date, the LRAH panel has been exposed to a range of furnace-firing conditions for a total of $726 \mathrm{hr}$. Natural gas firing represents $457 \mathrm{hr}$ and coal-lignite firing represents $269 \mathrm{hr}$. The longest continuous coal-fired period was $80 \mathrm{hr}$, completed in March 1998. In addition, the LRAH panel has been exposed to seven heatup and cooldown cycles.

Exhibits 2.2-62 through 2.2-64 summarize the LRAH ceramic tile temperatures, tube surface temperatures, and CA temperatures for the April test period. The CA flow rate data for the LRAH panel were summarized in Exhibit 2.2-46. Exhibit 2.2-65 illustrates the location of thermocouples in the LRAH panel, and Exhibit 2.2-66 provides a description of the LRAH thermocouples. 


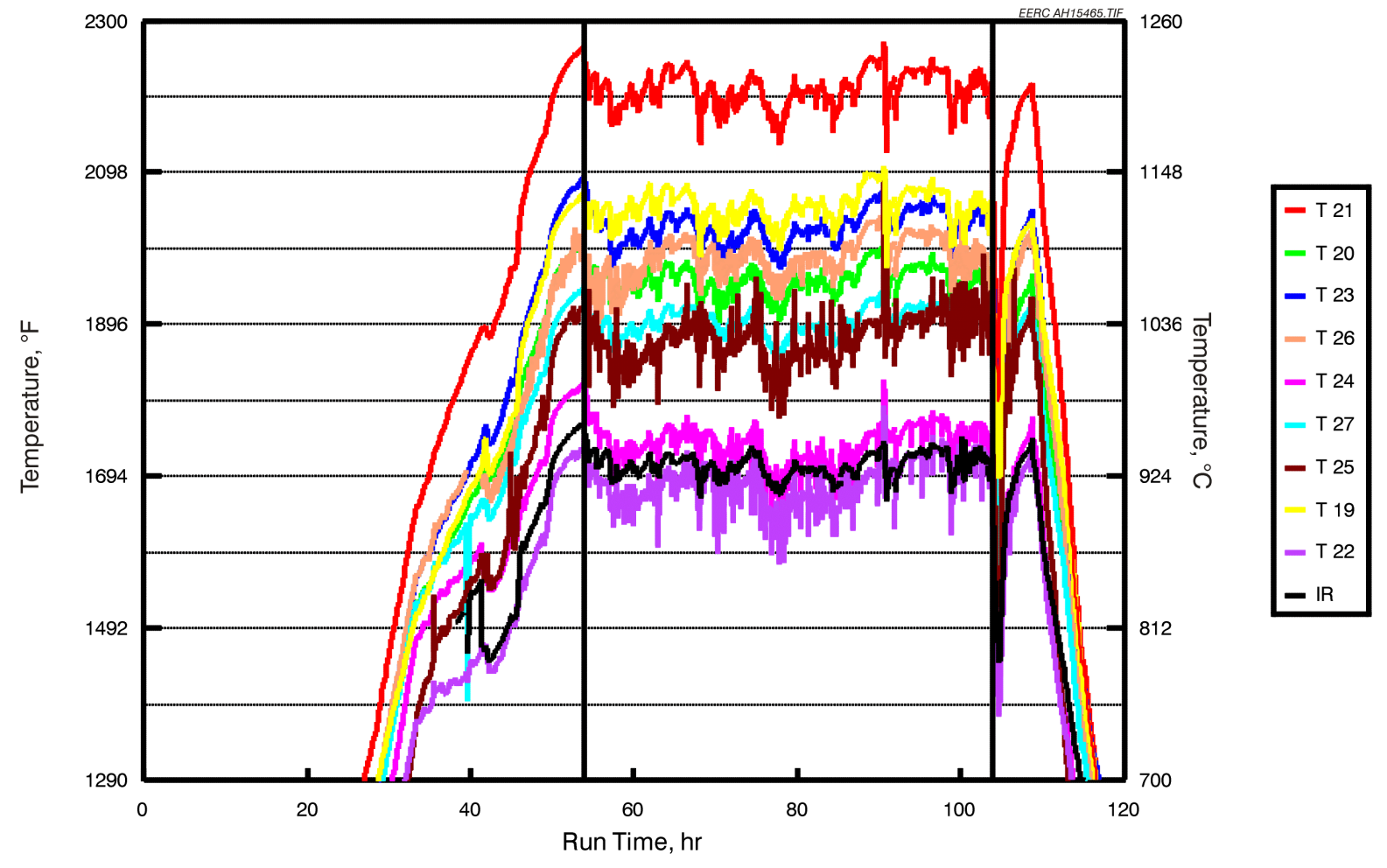

Exhibit 2.2-62

LRAH Ceramic Tile Temperatures versus Run Time for the April Test period 


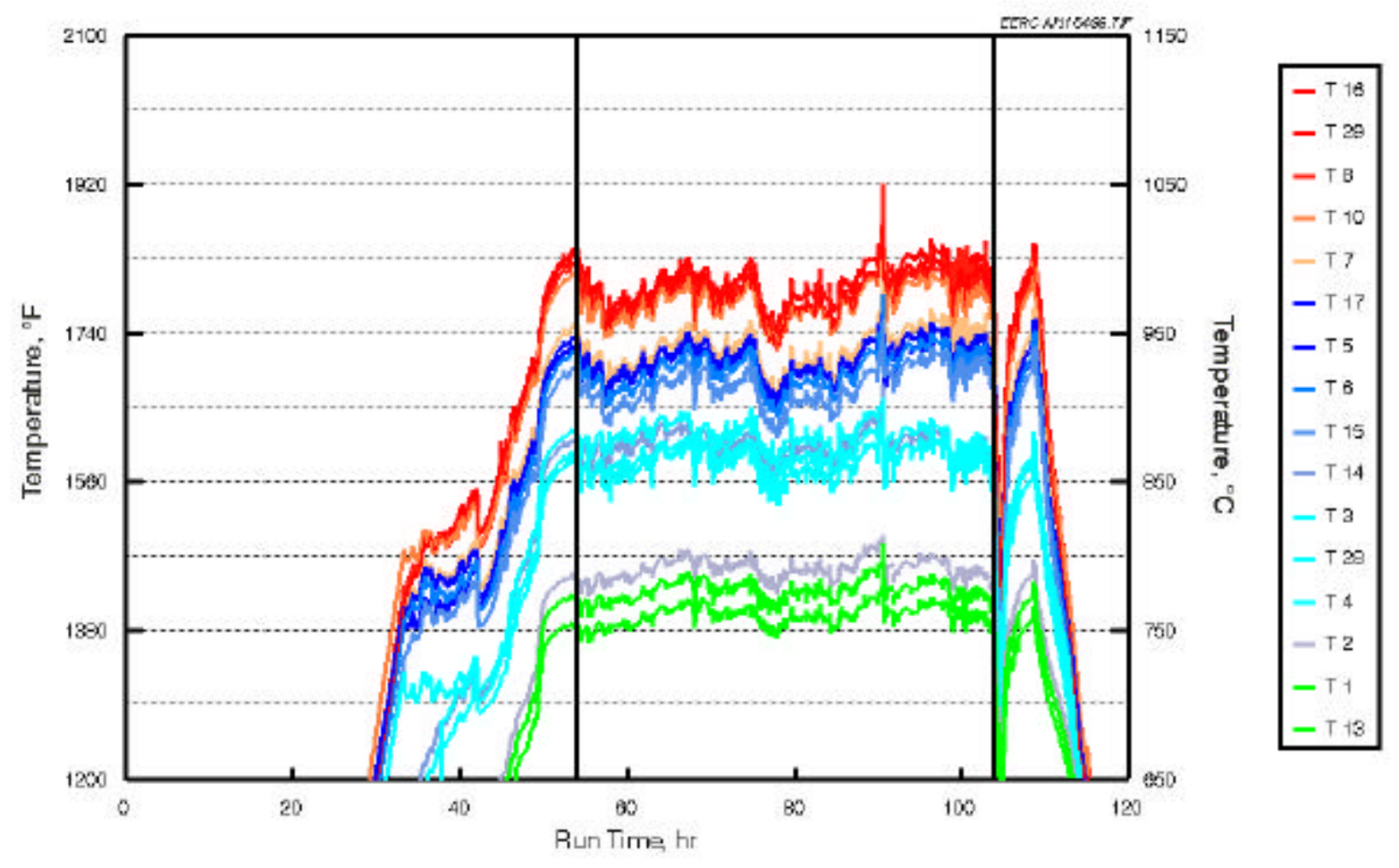

Exhibit 2.2-63

LRAH Tube Surface Temperatures versus Run Time for the April Test 


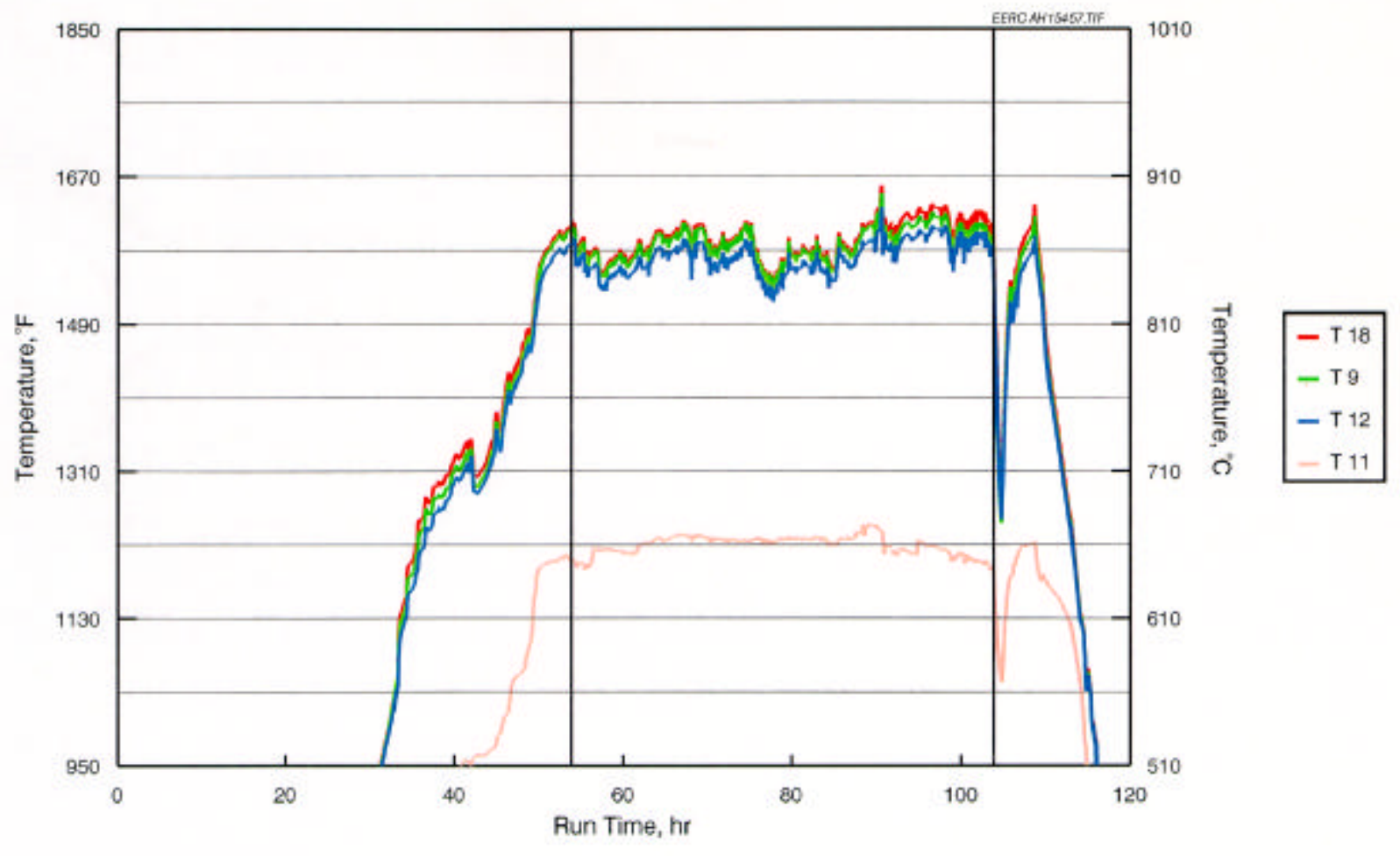

Exhibit 2.2-64

LRAH Cooling Air Temperatures versus Run Time for the April Test Period 


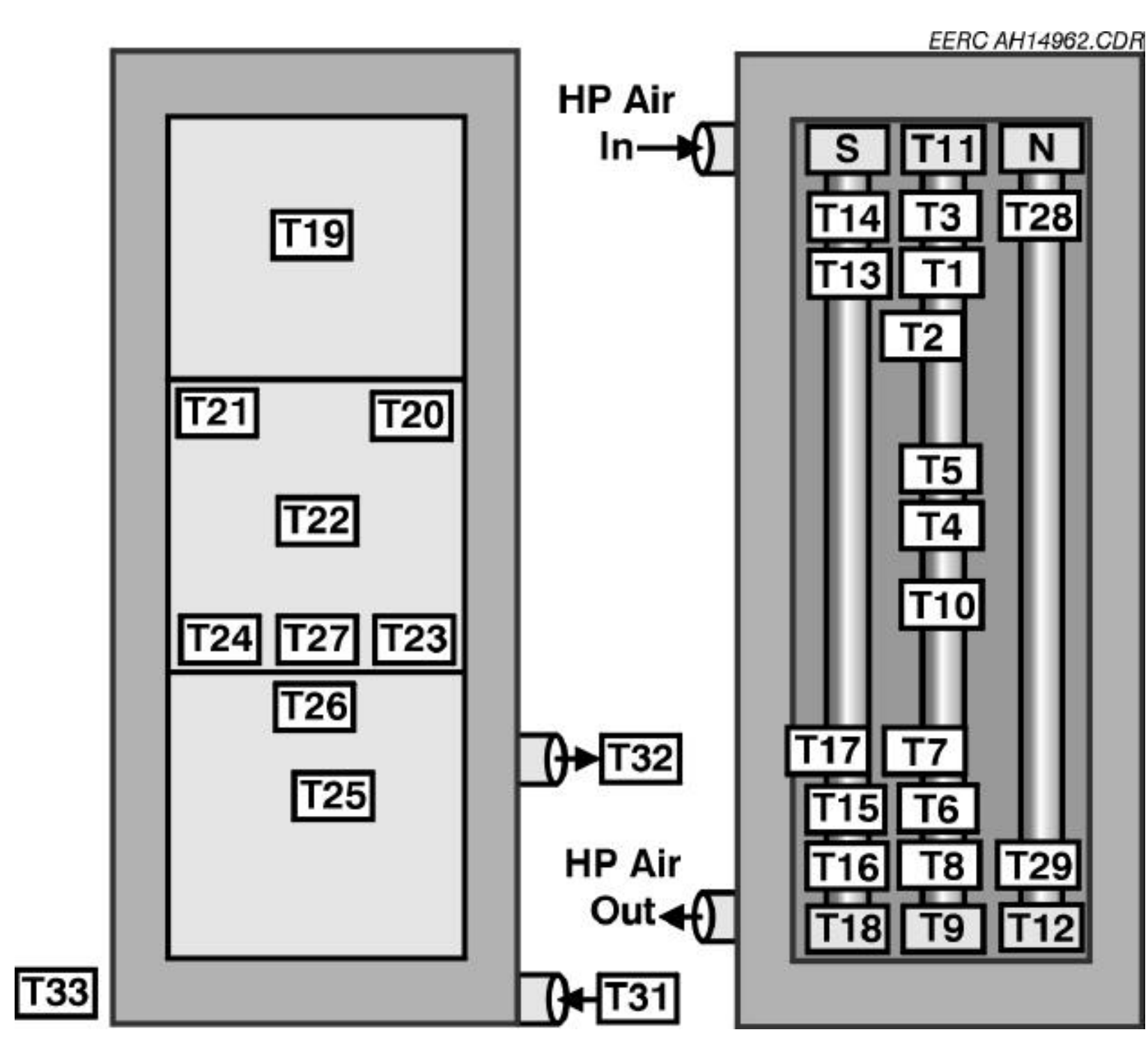

Exhibit 2.2-65

Illustration of Thermocouple Locations in the LRAH Panel

The ceramic tile surface temperatures ranged from nominally $1635^{\circ}\left(891^{\circ}\right)$ to $2260^{\circ} \mathrm{F}$ $\left(1238^{\circ} \mathrm{C}\right)$ once the SFS had stabilized thermally (Run Hours 50 through 104). However, based on an inspection of the inside of the LRAH panel with a boroscope before the April test period the thermocouples (T19, T22, and T25) measuring surface temperatures at the center of each of the three large ceramic tiles were found to be no longer attached. Therefore, although the data from these thermocouples are presented in the figure, the data are believed to be invalid. The highest tile surface temperatures were measured at the top corners of the large middle tile where the ceramic material is thinner and the potential for flue gas leak effects is greatest. 


\begin{tabular}{|c|c|c|c|c|}
\hline \multicolumn{5}{|c|}{$\begin{array}{c}\text { Exhibit 2.2-66 } \\
\text { Description of LRAH Panel Thermocouple Locations }\end{array}$} \\
\hline Category & No. & Label & \multicolumn{2}{|l|}{ Description } \\
\hline Air Inlet & 1 & HP Air In & \multirow{2}{*}{\multicolumn{2}{|c|}{$\begin{array}{l}\text { Provided by the EERC, in pipe before inlet header. } \\
\text { Air entering RAH through center tube }\end{array}$}} \\
\hline & 2 & RAHT11 & & \\
\hline Air Outlet & 3 & RAHT18 & \multicolumn{2}{|c|}{ Air leaving left (south) tube } \\
\hline & 4 & RAHT9 & \multicolumn{2}{|c|}{ Air leaving middle tube } \\
\hline & 5 & RAHT12 & \multicolumn{2}{|c|}{ Air leaving right (north) tube } \\
\hline \multirow[t]{16}{*}{ MA Tube Surface } & 6 & RAHT1 & Top of middle tube & facing cold side \\
\hline & 7 & RAHT2 & & facing other tube \\
\hline & 8 & RAHT3 & & facing towards furnace \\
\hline & 9 & RAHT4 & Middle of middle tube & facing cold side \\
\hline & 10 & RAHT5 & & facing towards furnace \\
\hline & 11 & RAHT6 & & facing cold side \\
\hline & 12 & RAHT7 & & facing other tube \\
\hline & 13 & RAHT8 & (failed, ND2) & facing towards furnace \\
\hline & 14 & RAHT10 & Between 5 and 8 & facing towards furnace \\
\hline & 15 & RAHT13 & Top of left tube & facing cold side \\
\hline & 16 & RAHT14 & & facing towards furnace \\
\hline & 17 & RAHT15 & Bottom of left tube & facing cold side \\
\hline & 18 & RAHT16 & & facing towards furnace \\
\hline & 19 & RAHT17 & & facing towards side wall \\
\hline & 20 & RAHT28 & Top of right tube & facing towards furnace \\
\hline & 21 & RAHT29 & Bottom of right tube & facing towards furnace \\
\hline \multirow{9}{*}{$\begin{array}{l}\text { Inner Surface of } \\
\text { Monofrax bricks }\end{array}$} & 22 & RAHT19 & Top brick & center \\
\hline & 23 & RAHT20 & Middle brick & right top corner \\
\hline & 24 & RAHT21 & & left top corner \\
\hline & 25 & RAHT22 & & center \\
\hline & 26 & RAHT23 & (failed, ND2, Hr 97) & right bottom corner \\
\hline & 27 & RAHT24 & & left bottom corner \\
\hline & 28 & RAHT27 & & bottom center edge \\
\hline & 29 & RAHT25 & Lower brick & center \\
\hline & 30 & RAHT26 & (failed, ND2, Hr 97 & top of center edge \\
\hline
\end{tabular}

${ }^{1}$ Thermocouple locations are illustrated in Exhibit 2.2-65.

LRAH CA flow rates during the April test period were controlled at 200 and $180 \mathrm{scfm}$ (5.7 and $5.1 \mathrm{~m}^{3} / \mathrm{min}$ ). Changes in CA flow rates had a definite effect on indicated tile surface temperatures. As CA flow rates were reduced, tile surface temperature increased. Later, when CA flow rates were increased, tile surface temperatures decreased. Although difficult to see because of lignite feed problems, this effect is visible in the figure between Run Hours 60 and 80 and again at Run Hours 80 to 100. 
LRAH tube surface temperatures ranged from nominally 1380 to $1844^{\circ} \mathrm{F}$ ( 749 to $1007^{\circ} \mathrm{C}$ ). The low end of the temperature range represents the back side of the tube surfaces near the CA inlet, with the high end of the temperature range representing the front side of the tube surfaces near the $\mathrm{CA}$ outlet. Changes in $\mathrm{CA}$ flow rates had noticeable effects on all tube surface temperatures. Tube surface temperature step changes were most noticeable for surface temperature measurements near the CA exit and on the front side of the tubes.

CA temperature data are presented in Exhibit 2.2-64. The CA inlet temperature was fairly stable, nominally 1200 to $1250^{\circ} \mathrm{F}\left(649\right.$ to $\left.677^{\circ} \mathrm{C}\right)$. Outlet CA temperatures ranged from nominally 1523 to $1628^{\circ} \mathrm{F}\left(829\right.$ to $887^{\circ} \mathrm{C}$ ). The effect of $\mathrm{CA}$ flow rate can be seen in the CA outlet temperature data. As CA flow rate decreases, CA exit temperature increases as expected. These CA flow rate changes are noted at Run Hours 67 (reduced flow rate), 75 (increased flow rate), and 90 (reduced flow rate).

Heat recovery data from the LRAH panel are presented in Exhibit 2.2-67 for the April test period. At CA flow rates of 200 and $180 \mathrm{scfm}\left(5.7\right.$ and $\left.5.1 \mathrm{~m}^{3} / \mathrm{min}\right)$, the heat recovered from the LRAH panel during coal firing was 88,300 to 93,600 and 78,700 to $93,100 \mathrm{Btu} / \mathrm{hr}$ (93,156 to 98,748 and 83,028 to $98,220 \mathrm{~kJ} / \mathrm{hr}$ ), respectively. The main burner firing rate was nominally 2.5 to $2.7 \mathrm{MMBtu} / \mathrm{hr}\left(2.6\right.$ to $\left.28 \times 10^{6} \mathrm{~kJ} / \mathrm{hr}\right)$. The firing rate distribution between the main and auxiliary burners was $80 \%$ main and $20 \%$ auxiliary. No attempt was made to adjust the firing rate distribution between the main and auxiliary because of lignite feed rate stability problems.

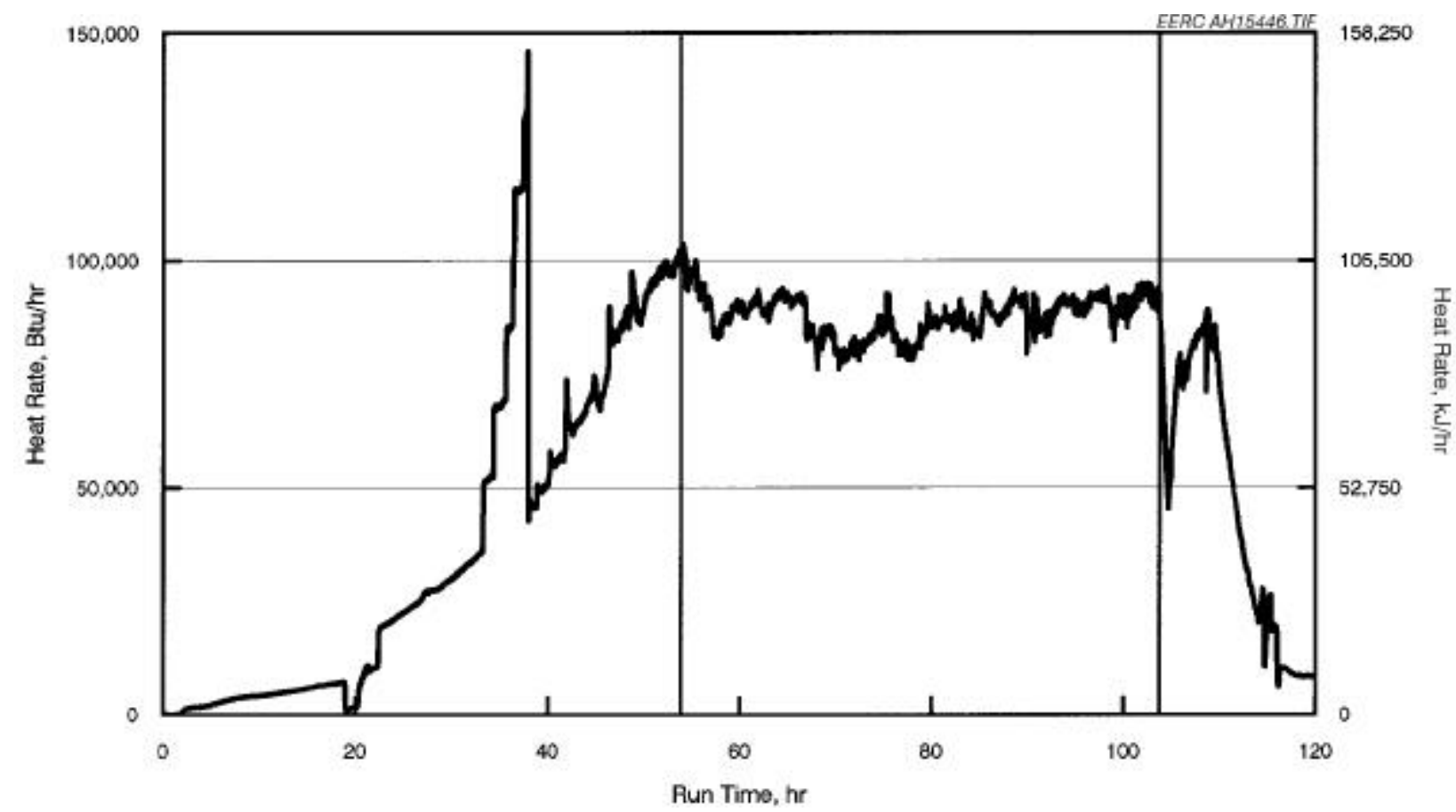

Exhibit 2.2-67

LRAH Heat Recovery versus Run Time for the April Test Period

Exhibits 2.2-68 and 2.2-69 present photographs of the LRAH panel from the interior of the furnace following the April test period. Exhibit 2.2-68 is a photograph taken from above and outside of the furnace showing both the LRAH and SRAH panels. Exhibit 2.2-69 is a photograph 
of the LRAH panel taken from below and inside of the furnace. The photograph indicates that the ceramic tiles coated to a significant degree with a layer of slag/refractory and that slag/refractory was dripping off of the small bottom support brick and onto the furnace wall. There is also evidence of slag running down the furnace wall toward the slag tap. Also, some furnace refractory damage is evident above the LRAH panel in Exhibit 2.2-68, indicating that furnace refractory was contributing to the slag running down the surface of the LRAH tiles/bricks. This furnace refractory damage was repaired prior to the June test period. Exhibit 2.2 -69 shows areas where small patches of slag/refractory scale were removed from the surface of the ceramic tiles. However, most of the slag/refractory is tightly bonded to the ceramic tile surface.

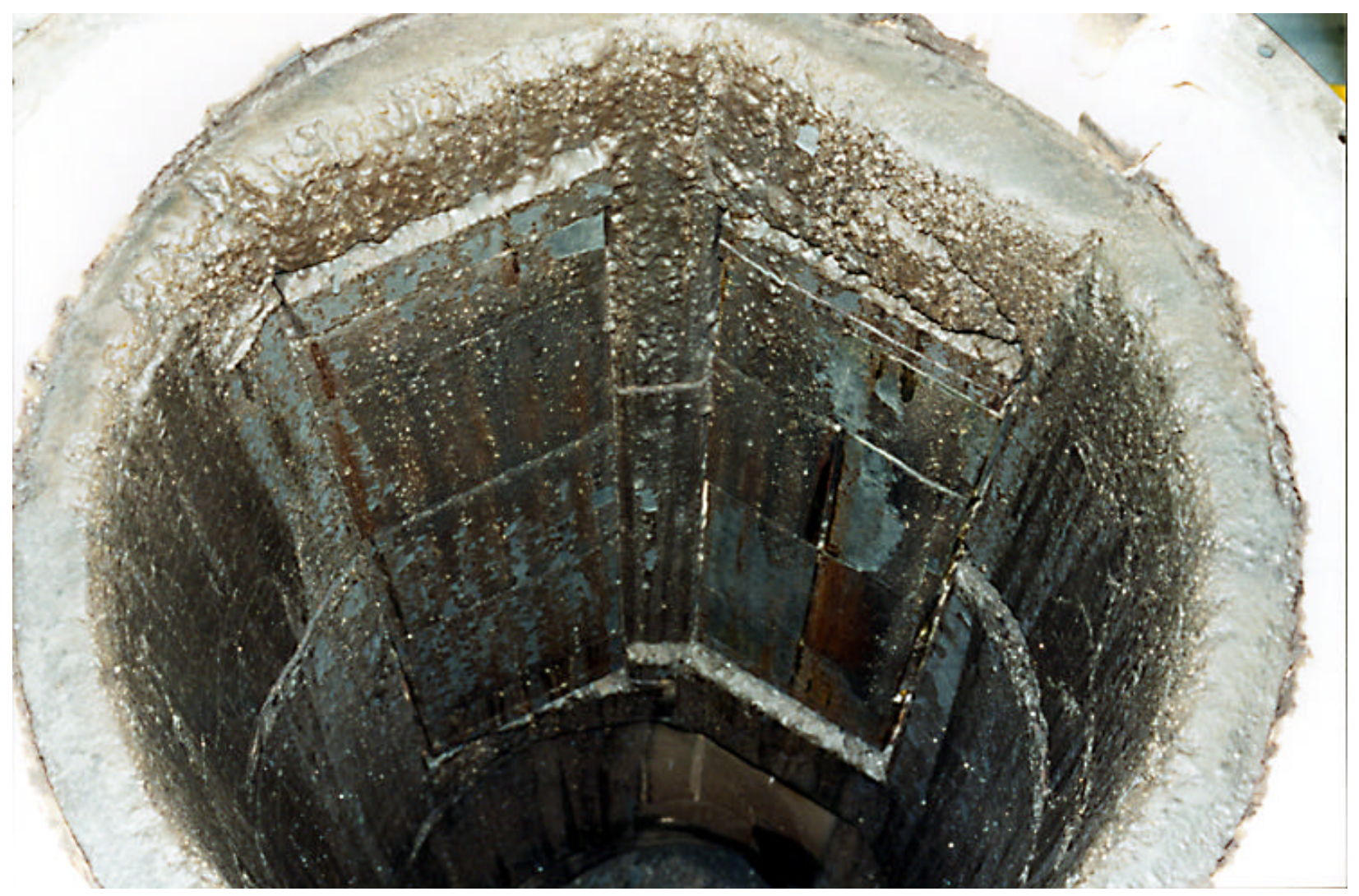

Exhibit 2.2-68

Photograph of LRAH and SRAH Panels inside of the Slagging Furnace Following the April Test Period 


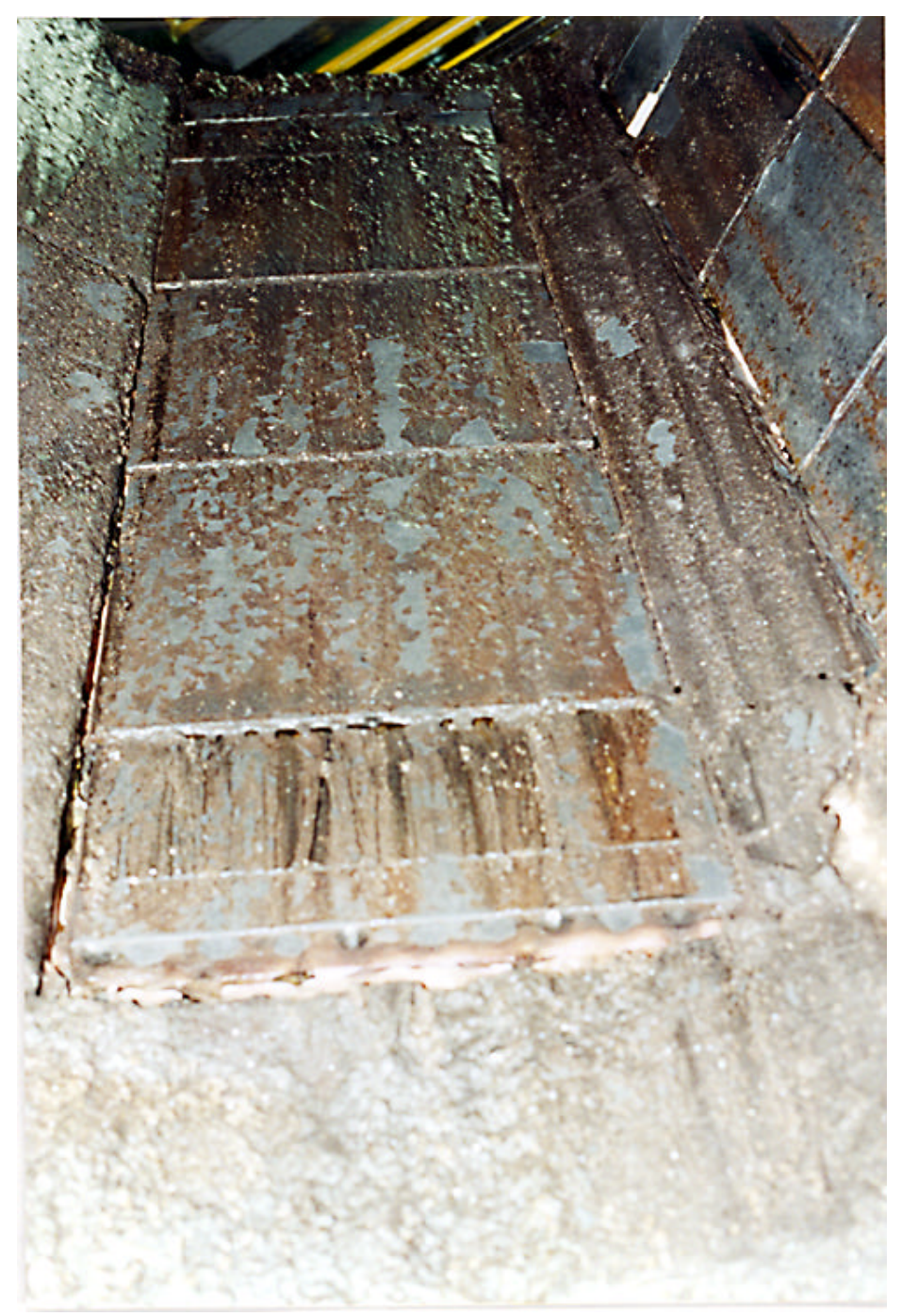

Exhibit 2.2-69

Photograph of the LRAH Panel from Inside of the Furnace after the April Test Period

Exhibits 2.2-70 through 2.2-72 summarize the LRAH ceramic tile temperatures, tube surface temperatures, and CA temperatures for the June test period. The CA flow rate data for the LRAH panel are summarized in Exhibit 2.2-54. The ceramic tile surface temperatures ranged from nominally 1730 to $2270^{\circ} \mathrm{F}$ (944 to $1244^{\circ} \mathrm{C}$ ) when the SFS was fired on Center lignite at $100 \%$ load (Run Hours 26 through 50 and 60 through 76). However, thermocouples T22 and T24 were no longer attached. Therefore, although the data from these thermocouples are presented in the Exhibit, the data are considered to be suspect. As observed previously, the highest tile surface temperatures were measured at the top corners of the large middle tile where the ceramic material is thinner and the potential for flue gas leak effects is greatest. LRAH CA flow rates during the June test period were controlled at 200 and $180 \mathrm{scfm}\left(5.7\right.$ and $\left.5.1 \mathrm{~m}^{3} / \mathrm{min}\right)$. Changes in CA flow rates had a definite effect on indicated tile surface temperatures but the effect is difficult to see in Exhibit 2.2-70. As CA flow rates were reduced, tile surface temperature increased. This effect can be seen at Run Hours 44, 69, and 73 . 


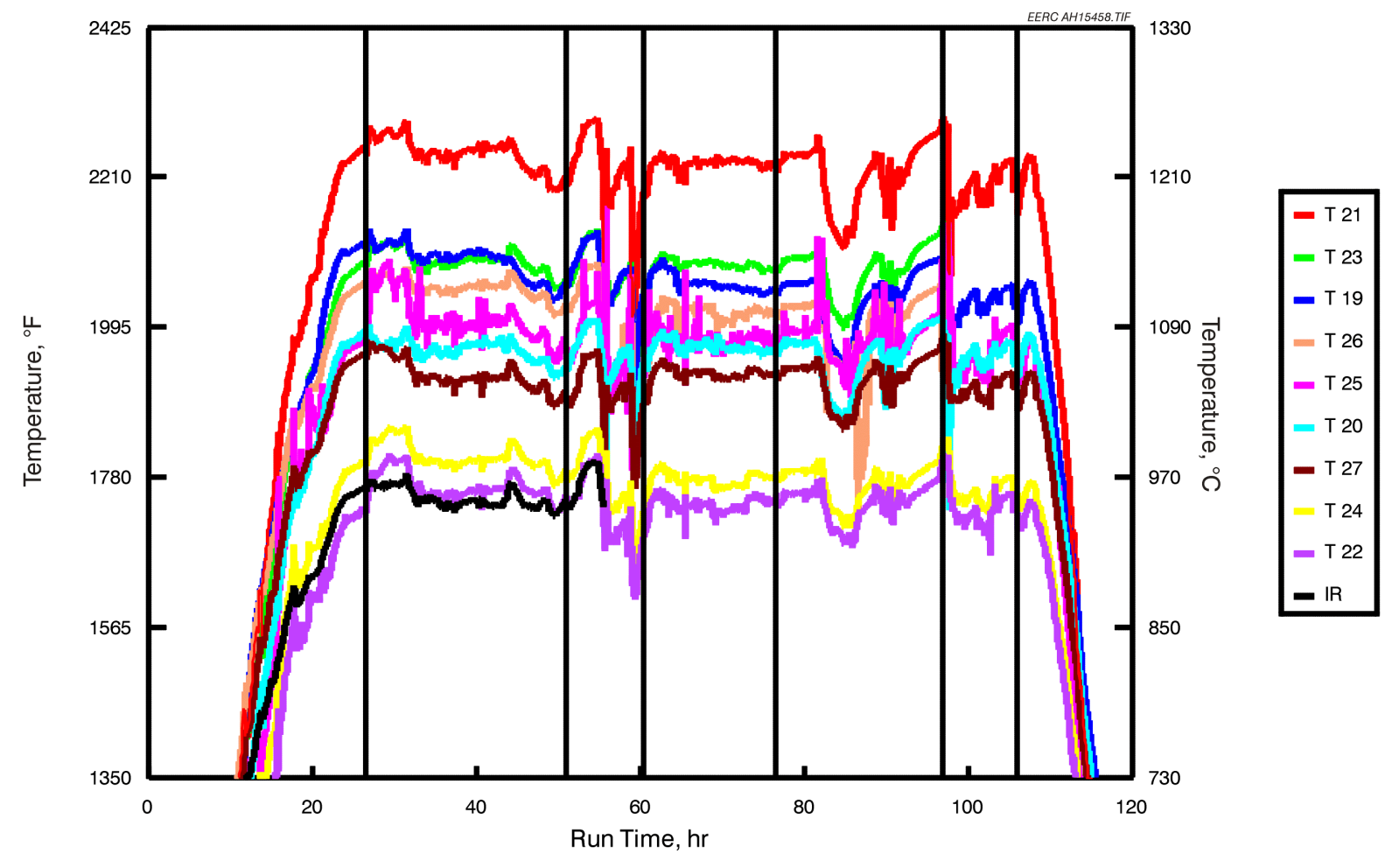

Exhibit 2.2-70

LRAH Ceramic Tile Temperatures versus Run Time for the June Test Period 


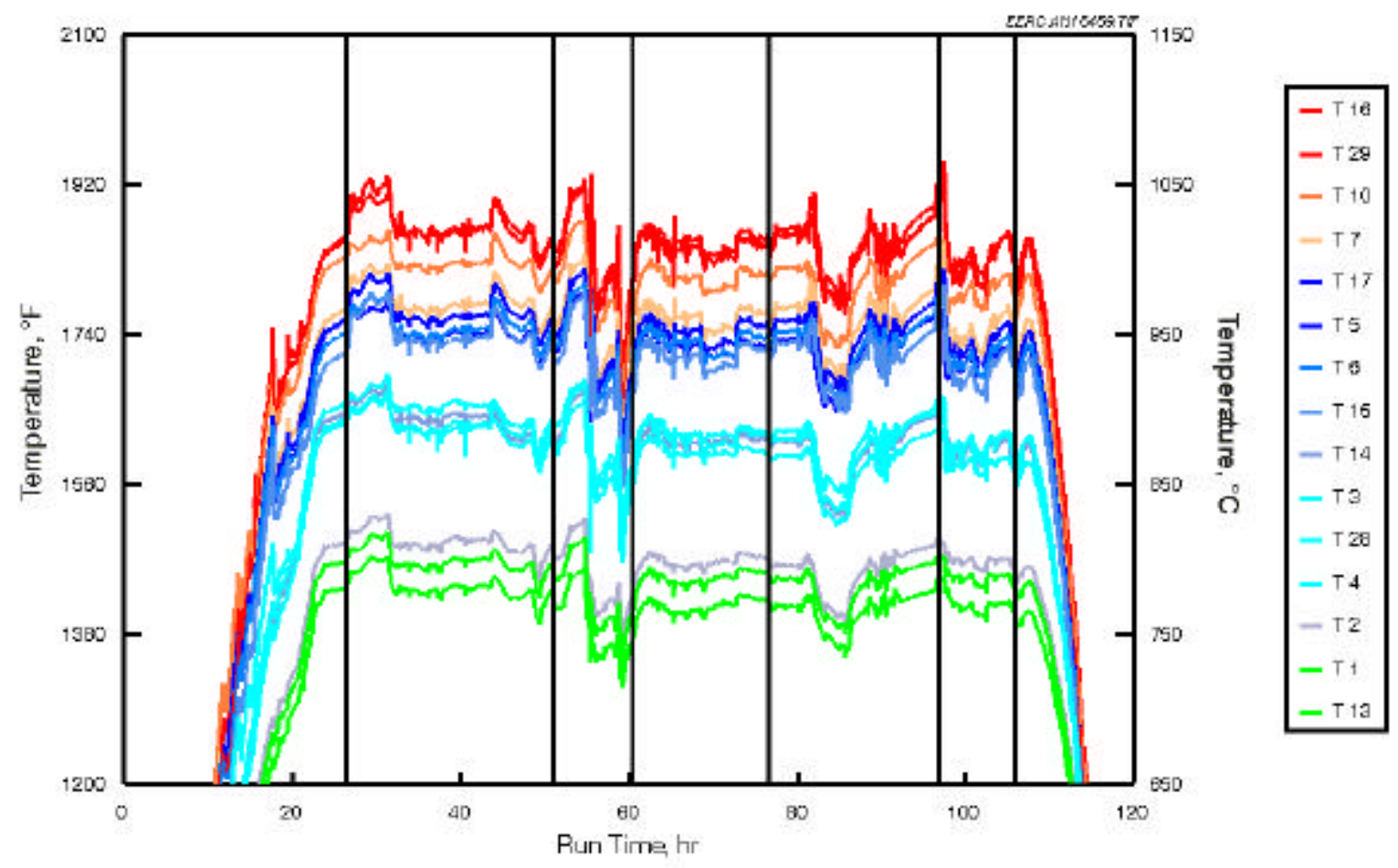

Exhibit 2.2-71

LRAH Tube Surface Temperatures versus Run Time for the June Test Period 


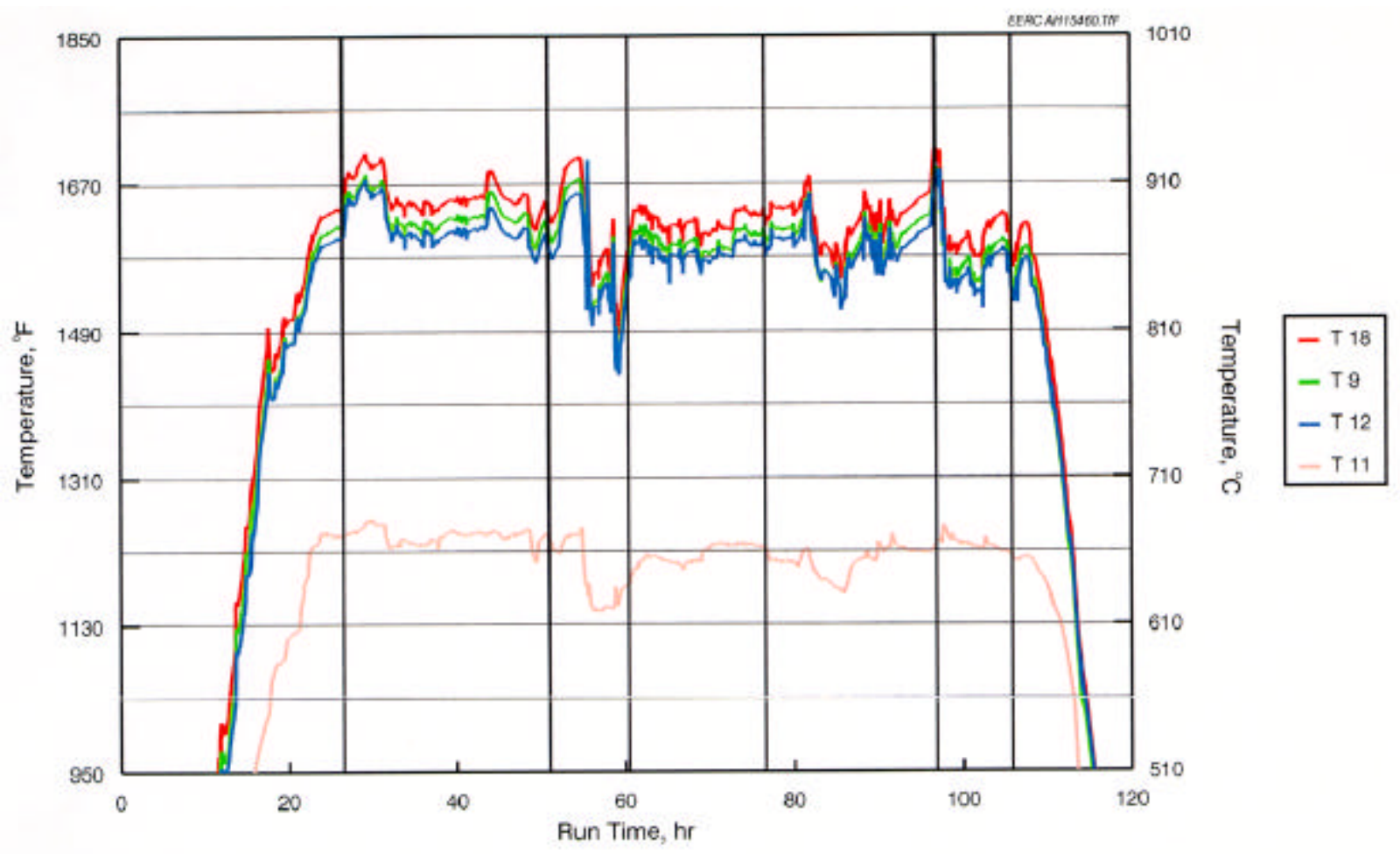

Exhibit 2.2-72

LRAH Cooling Air Temperatures versus Run Time for the June Test Period

LRAH tube surface temperatures ranged from nominally 1405 to $1925^{\circ} \mathrm{F}\left(763\right.$ to $\left.1041^{\circ} \mathrm{C}\right)$ for Run Hours 26 through 50 and 60 through 76. The low end of the temperature range represents the back side of the tube surfaces near the CA inlet, with the high end of the temperature range representing the front side of tube surfaces near the CA outlet. CA temperatures were nominally 1205 to $1260^{\circ} \mathrm{F}\left(652\right.$ to $\left.682^{\circ} \mathrm{C}\right)$ at the inlet of the tubes and 1575 to $1690^{\circ} \mathrm{F}\left(858\right.$ to $\left.921^{\circ} \mathrm{C}\right)$ at the outlet of the tubes.

Heat recovery data from the LRAH panel are presented in Exhibit 2.2-73 for the June test period. CA flow rate step changes are very evident in the Exhibit at Run Hours 44, 69, and 73. At CA flow rates of 200 and $180 \mathrm{scfm}\left(5.7\right.$ and $\left.5.1 \mathrm{~m}^{3} / \mathrm{min}\right)$, the heat recovered from the LRAH panel during coal firing was 91,350 to 106,700 and 87,500 to $94,200 \mathrm{Btu} / \mathrm{hr}(96,374$ to 112,568 and 92,312 to $99,381 \mathrm{~kJ} / \mathrm{hr}$ ), respectively. The main burner firing rate was nominally 2.5 to 2.6 MMBtu/hr ( 2.6 to $2.7 \times 10^{6} \mathrm{~kJ} / \mathrm{hr}$ ). The firing rate distribution between the main and auxiliary burners was $78 \%-79 \%$ main and $21 \%-22 \%$ auxiliary. No attempt was made to increase the main burner firing rate and decrease the auxiliary burner firing rate because of a few system operating problems related to ash deposition and slag flow. As expected, temperatures and flow rates were very stable for individual test periods once furnace conditions and CA flow rates were stabilized. SFS stability was better when firing the Center lignite because the fuel feed was more stable when compared to the Coal Creek-Falkirk lignite (high surface moisture). 


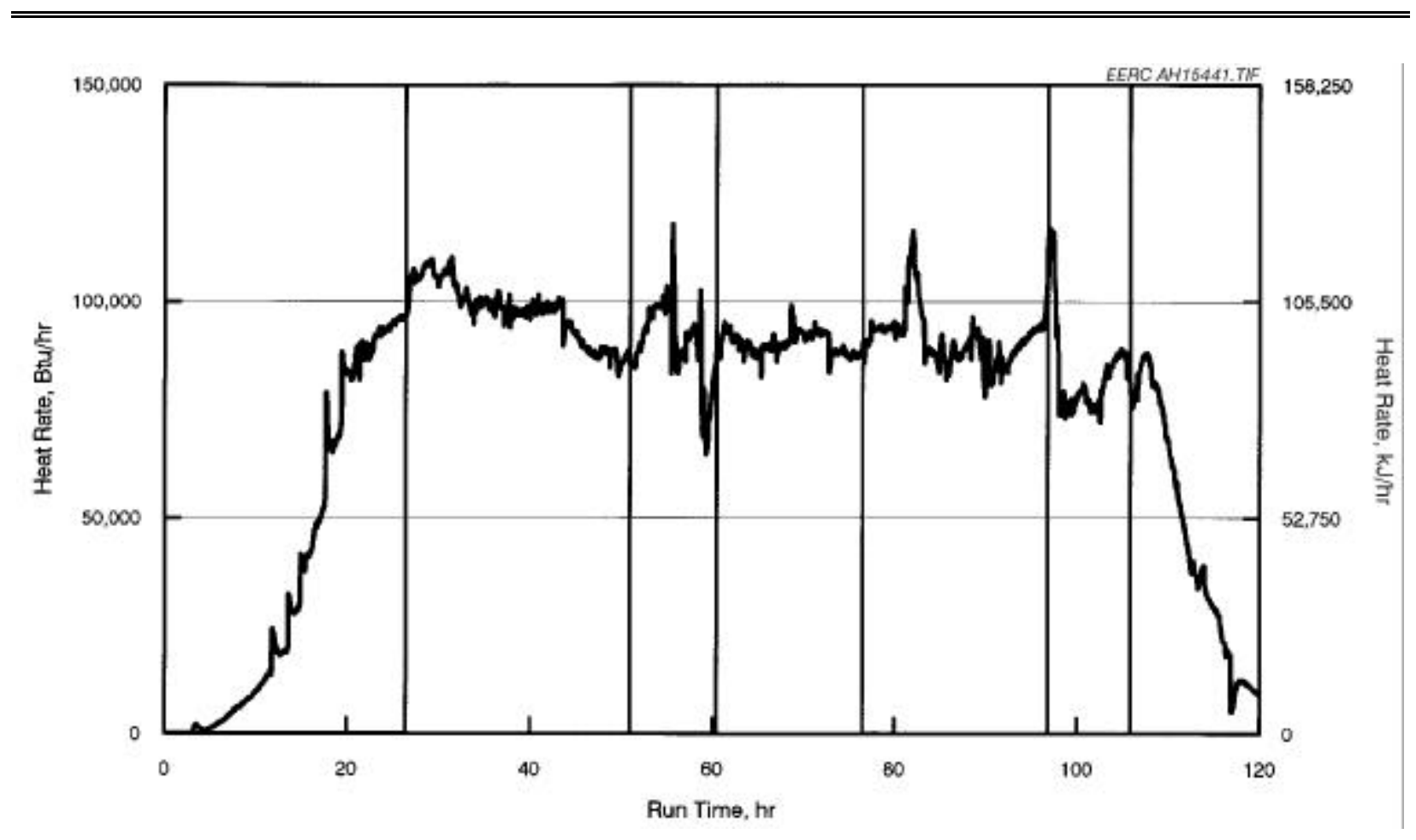

Exhibit 2.2-73

LRAH Heat Recovery versus Run Time for the June Test Period

Comparison of the LRAH panel heat recovery data for the April (Coal Creek-Falkirk lignite) and June (Center lignite) test periods indicates that overall heat recovery was greater in June than April even though the average lignite firing rates were similar. One possible explanation for the lower LRAH heat recovery in April may be a lower flame intensity because of a slightly higher moisture content. Another contributing factor may be the less stable fuel feed in April because of the higher fuel surface moisture. Still another possibility may be that the flame in June was more emissive because of the larger amount of vaporized inorganics from the Center lignite. Further review of the data will be necessary to determine the cause of the apparent difference in LRAH heat recovery for the two lignite test periods.

Exhibit 2.2-74 presents a photograph of the LRAH panel following the June test period. All of the individual ceramic tiles/bricks appear to be intact except for the large upper tile, which has a significant crack across the lower right corner. Other cracks present in the tiles/bricks are not evident in the photograph but are illustrated in Exhibit 2.2-61. The Exhibit 2.2-74 photograph, showing the entire LRAH and SRAH panels, indicates that the LRAH ceramic tiles/bricks are entirely coated with a slag layer and that slag is dripping from one tile/brick to the next and off of the small bottom support brick onto the furnace refractory. There is also evidence of slag running down the furnace wall to the slag tap. Furnace refractory damage above the RAH panels is evident in the photograph. 

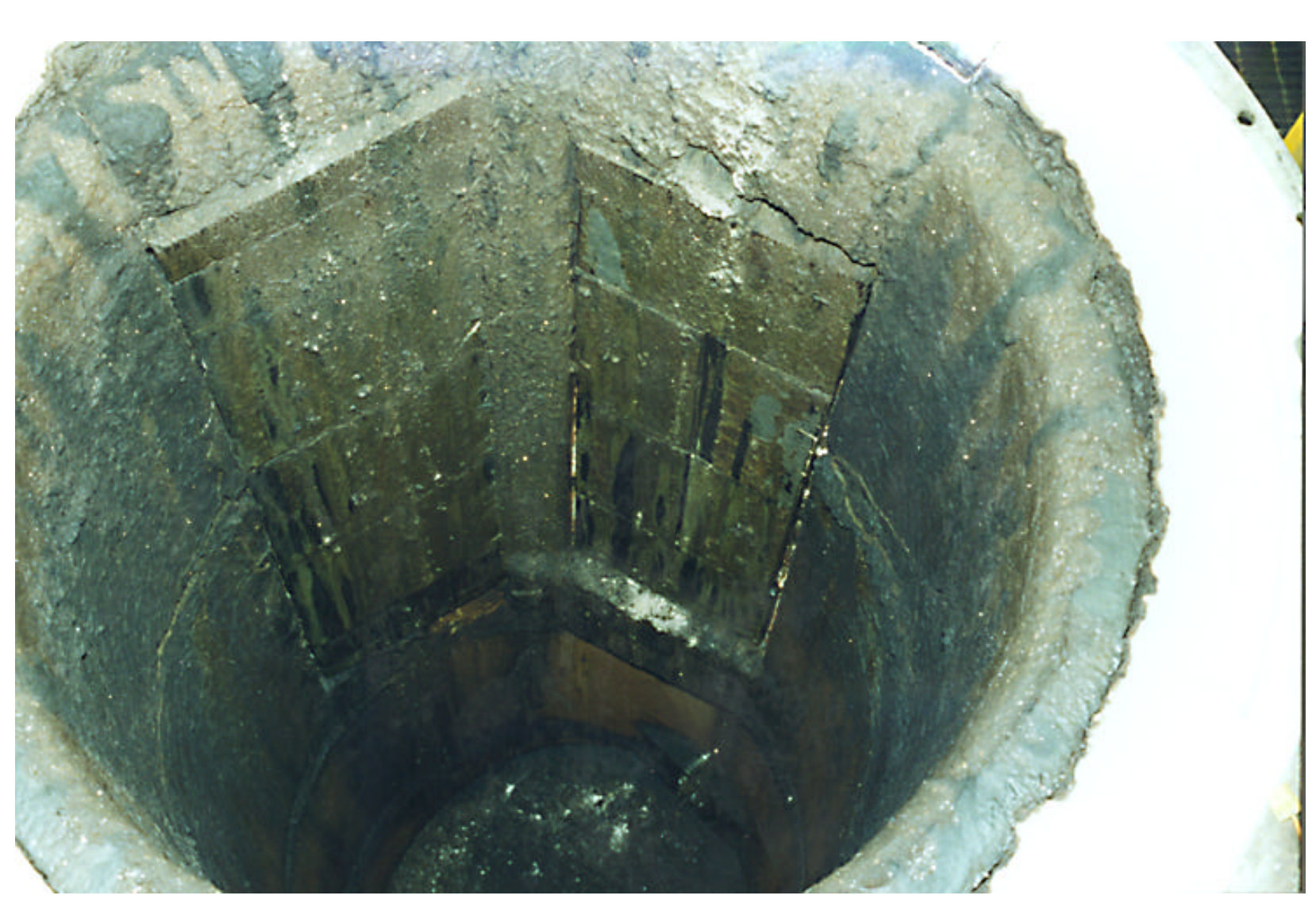

Exhibit 2.2-74

Photograph of the LRAH and SRAH Panels Inside of the Slagging Furnace Following the June Test Period

\section{Testing of the SRAH Panel}

Installation and initial testing of the SRAH panel occurred in April 1998. Testing of the SRAH panel this past quarter evaluated panel performance relative to heat transfer, tile temperatures, and cooling water temperatures and flow rates while firing two lignite fuels. In general, the performance of the SRAH panel this past quarter was as anticipated, with no significant process problems.

The SRAH panel was thoroughly inspected following each week of operation this quarter. Upon inspection after the April test period, the upper support brick, the small upper tile, and the upper right middle tile had suffered sufficient damage to warrant replacement prior to the June test period. The photograph in Exhibit 2.2-68 shows the horizontal crack across the face of the upper support brick and the vertical crack along the right edge of the upper right middle tile. The damage to the small upper tile is not visible in this photograph. Exhibit 2.2-75 is a photograph of the SRAH panel after the three damaged tiles/bricks were replaced prior to the June test period. 


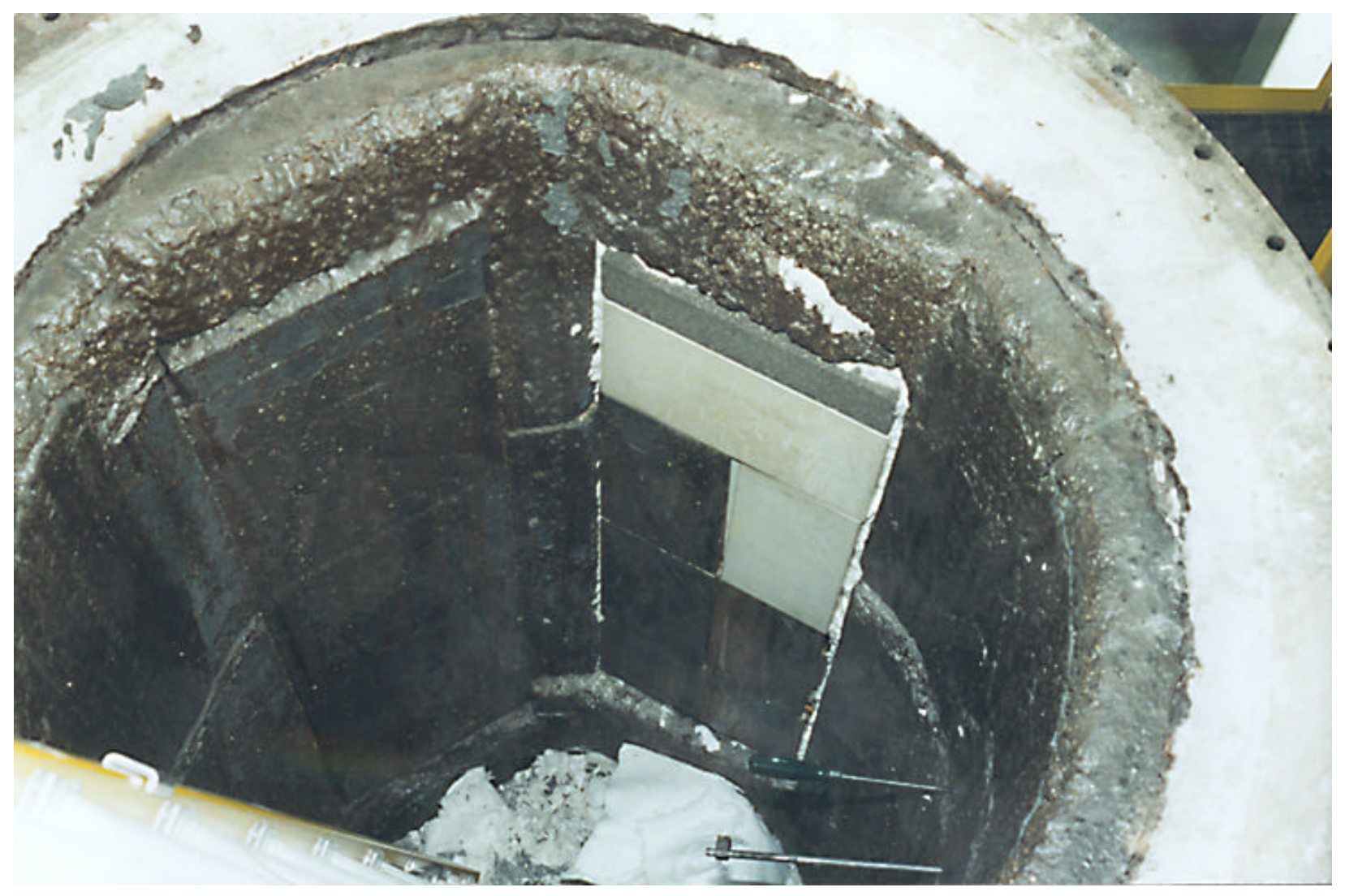

\section{Exhibit 2.2-75 \\ Photograph of the SRAH Panel Following Replacement of the Damaged Tiles/Bricks Prior to the June Test Period}

Exhibit 2.2-76 shows the status of the tile/brick (SRAH panel) cracking after the June test period was completed. The SRAH panel has a fairly uniform layer of slag/refractory on the surface, except for a small area of the small upper tile and an area of the upper right middle tile where scale type pieces were removed. These areas are visible in Exhibit 2.2-74. This slag/refractory material is strongly attached to the ceramic tiles/bricks and cannot be removed. All of the horizontal seams between the tiles or bricks are filled with slag although the slag is cracked in all of the seams except for the seams between the top support brick and the furnace refractory, between the upper and lower left middle tiles, and between the lower right middle and small lower tile. 


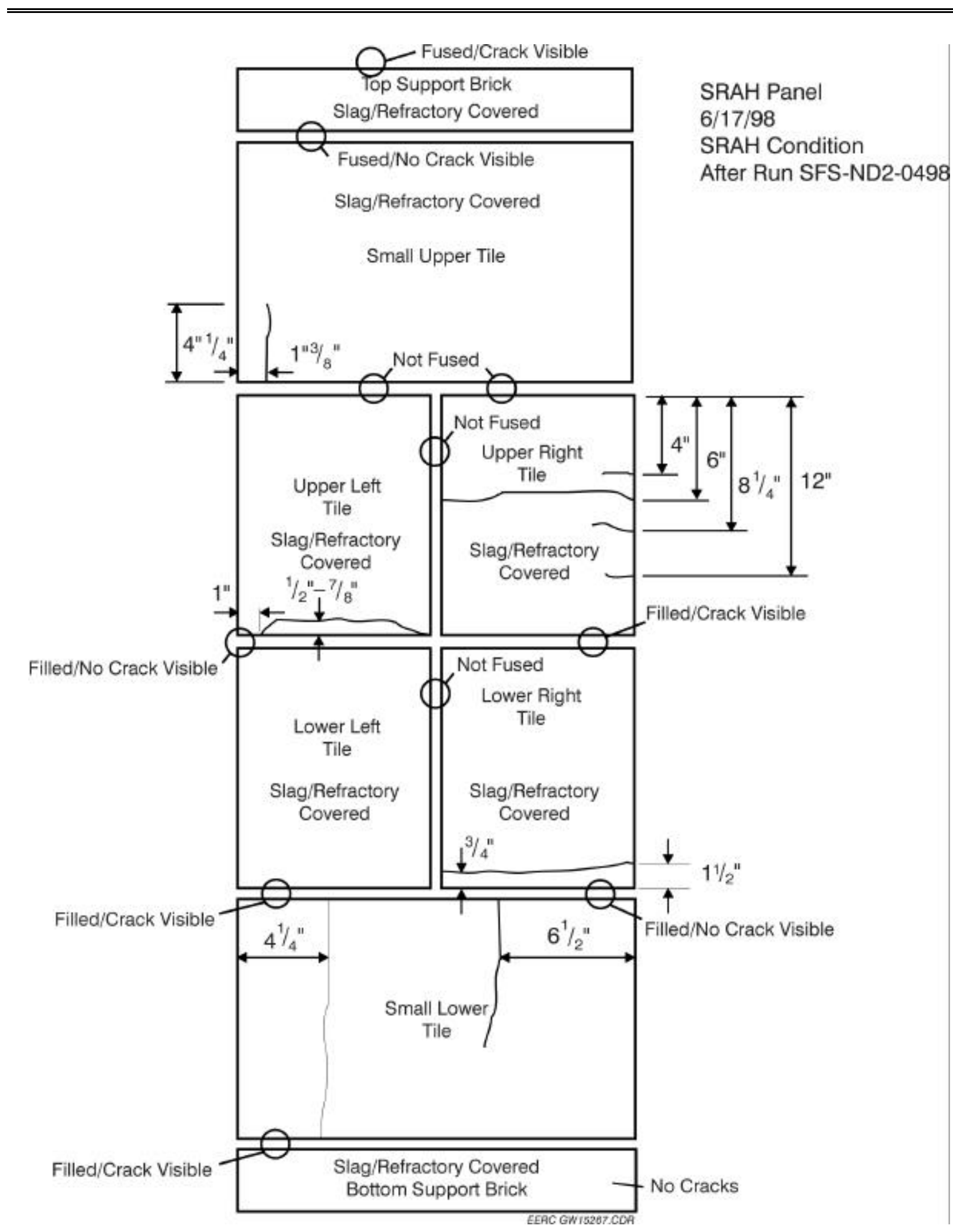

Exhibit 2.2-76

Illustration of Cracks Found in the Ceramic Tiles/Bricks of the SRAH Panel after Testing in June 1998 
There are no visible cracks in the top support brick. The small upper tile has a vertical hairline crack in the lower left corner but generally appears to be in good condition. The horizontal seam between the small upper tile and upper middle tiles is not fused with slag. Neither is the vertical seam between the upper and lower middle tiles. The upper left middle tile has a crack on the lower edge. Four horizontal cracks are visible in the upper right middle tile, one completely across the face and three that are $<4$ in. $(<10 \mathrm{~cm})$ in length originating from the right edge. These cracks do not appear to be serious. The lower left middle tile has no visible cracks, while the lower right middle tile has a horizontal crack across the lower edge. However, the lower right middle tile does not appear to be in danger of failing. Two vertical cracks are visible in the small lower tile. The crack on the left extends across the entire face, while the crack on the right only extends across two-thirds of the face. Neither crack appears to be serious at this time. There are no visible cracks in the bottom support brick.

Although nearly all of the tiles/bricks show some degree of cracking that may be an indication of structural strength problems, there is no evidence at this time of impending failure of any of the individual ceramic tiles/bricks. Therefore, there are no plans to replace any SRAH panel tiles/bricks before the next test period scheduled in August. The EERC will continue to document ceramic tile/brick cracking after each test is completed with the SRAH panel.

To date, the SRAH panel has been exposed to a range of furnace-firing conditions for a total of $283 \mathrm{hr}$. Natural gas firing represents $181 \mathrm{hr}$ and lignite firing represents $102 \mathrm{hr}$. The longest continuous lignite-fired period was $50 \mathrm{hr}$, completed in April 1998. In addition, the SRAH panel has been exposed to two heatup and cooldown cycles.

Exhibit 2.2-77 summarizes the SRAH ceramic tile temperatures for the April test period. Exhibit 2.2 -78 illustrates the location of thermocouples in the SRAH panel, and Exhibit 2.2-79 provides a description of the SRAH thermocouples. The ceramic tile surface temperatures ranged from nominally $1440^{\circ}$ to $2570^{\circ} \mathrm{F}\left(782\right.$ to $1410^{\circ} \mathrm{C}$ ) once the SFS had stabilized thermally (Run Hours 50 through 104). The highest tile surface temperatures were generally measured at or near the furnace side of the tiles. Lower tile temperatures were measured on the back or cavity surface of the tiles or in the cavity. 


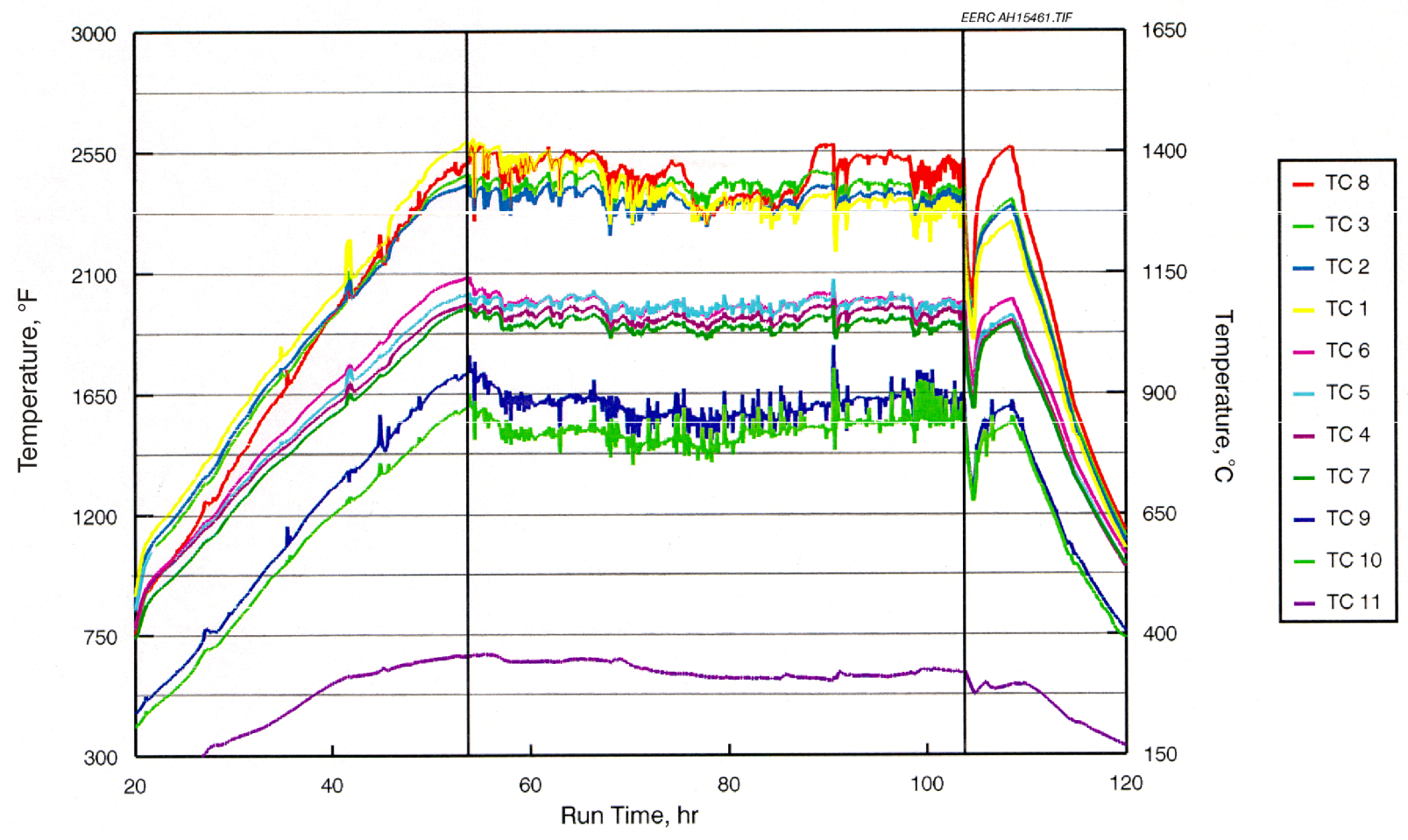

Exhibit 2.2-77

SRAH Ceramic Tile Temperatures versus Run Time for the April Test Period 


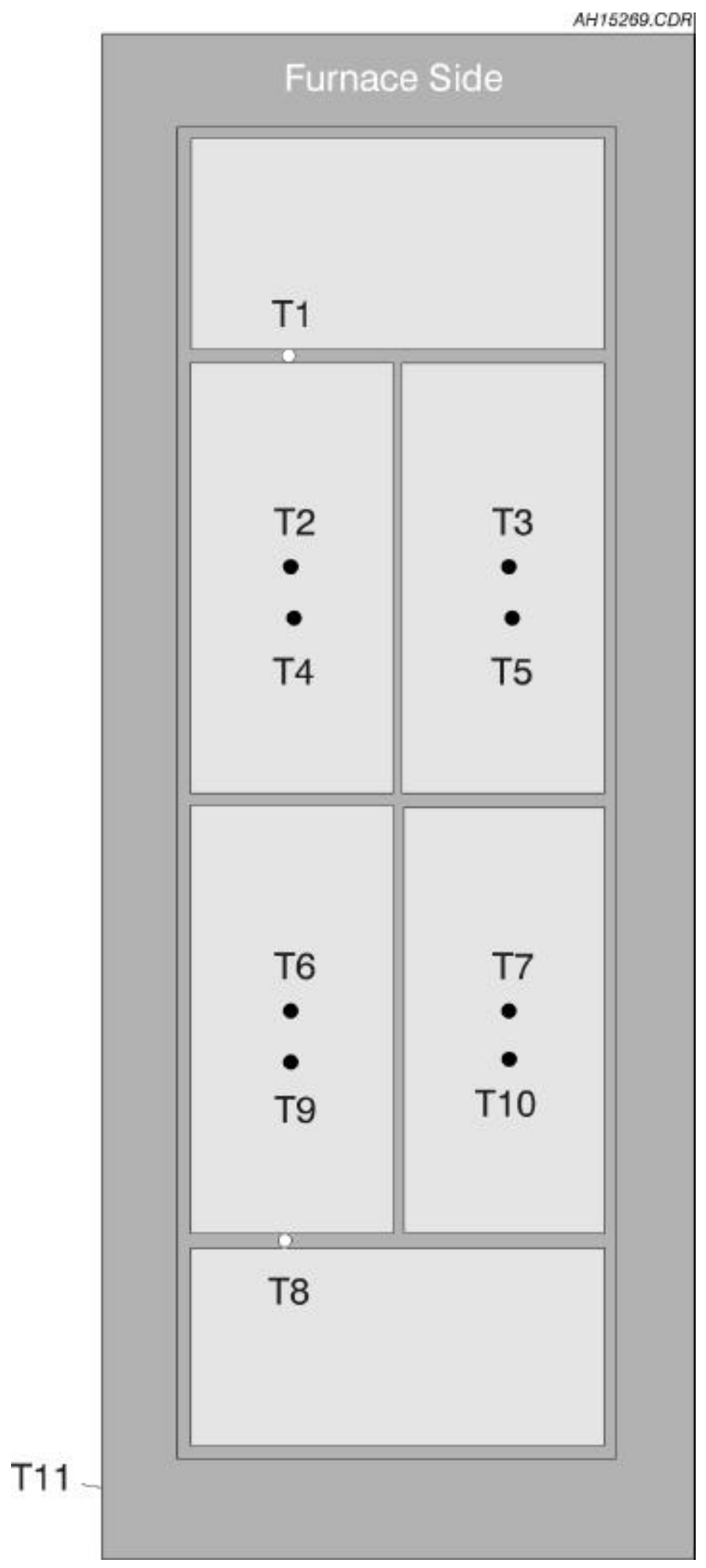

Exhibit 2.2-78

Illustration of Thermocouple Locations in the SRAH Panel 
SRAH panel cooling is accomplished with water rather than air. Therefore, the ceramic tile temperature variability shown in Exhibit 2.2-77 is a direct result of furnace-operating conditions. Cooling water flow rates are adjusted to control water exit temperature at $<140^{\circ} \mathrm{F}\left(60^{\circ} \mathrm{C}\right)$. The total cooling water flow rate during April test period was nominally $5 \mathrm{gal} / \mathrm{min}(19 \mathrm{~L} / \mathrm{min})$.

Heat recovery data from the SRAH panel are presented in Exhibit 2.2 -80 for the April test. The SRAH heat recovery appeared to decrease with time. Nominal values ranged from 91,000 to $109,000 \mathrm{Btu} / \mathrm{hr}(95,900$ to $115,900 \mathrm{~kJ} / \mathrm{hr})$. The main burner firing rate was nominally 2.5 to 2.7 $\mathrm{MMBtu} / \mathrm{hr}\left(2.6\right.$ to $\left.2.8 \times 10^{6} \mathrm{~kJ} / \mathrm{hr}\right)$. The firing rate distribution between the main and auxiliary burners was $80 \%$ main and $20 \%$ auxiliary. No attempt was made to adjust the firing rate distribution between the main and auxiliary because of lignite feed rate stability problems.

Exhibit 2.2-79

Description of SRAH Panel Thermocouple Locations

\begin{tabular}{|c|c|c|c|}
\hline Category & No. & Label & Description \\
\hline \multirow[t]{2}{*}{ Furnace } & 1 & SRAH1 & $\begin{array}{l}\text { At interface between top and middle tile } \\
\text { (not in place for ND2) }\end{array}$ \\
\hline & 2 & SRAH8 & At interface between third and bottom tile \\
\hline \multirow[t]{2}{*}{ Surface, furnace side } & 3 & SRAH2 & Middle tile, upper left (not in place for ND2) \\
\hline & 4 & SRAH3 & Middle tile, upper right \\
\hline \multirow[t]{4}{*}{ Surface, cavity side } & 5 & SRAH4 & Middle tile, upper left \\
\hline & 6 & SRAH5 & Middle tile, upper right (not in place for ND2) \\
\hline & 7 & SRAH6 & Middle tile, lower left \\
\hline & 8 & SRAH7 & Middle tile, lower right \\
\hline \multirow[t]{2}{*}{ Cavity } & 9 & SRAH9 & Middle tile, lower left \\
\hline & 10 & SRAH10 & Middle tile, lower right \\
\hline Frame & 11 & SRAH11 & Cooling air exiting \\
\hline
\end{tabular}

${ }^{1}$ Thermocouple locations are illustrated in Exhibit 2.2-78. 


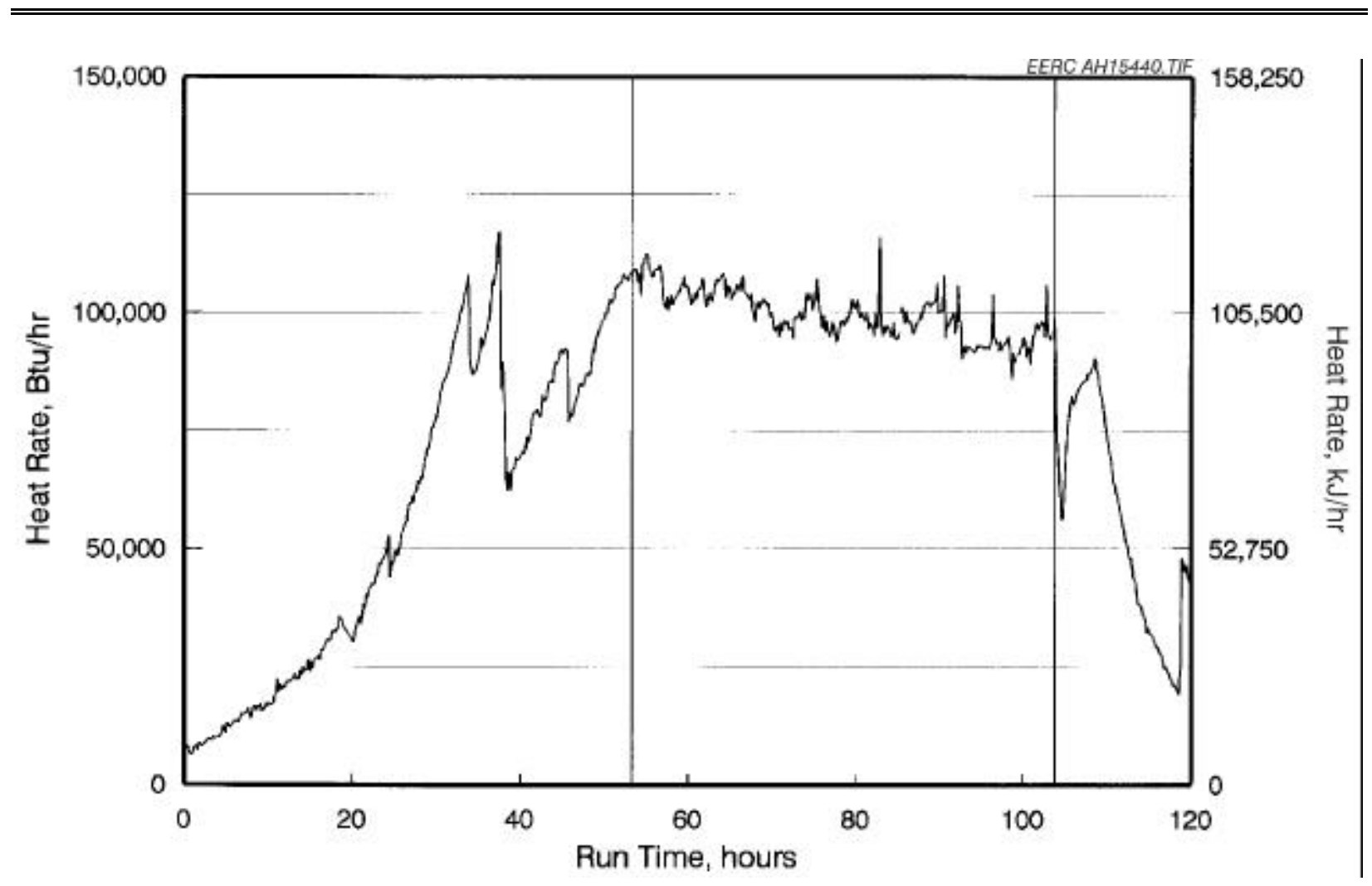

Exhibit 2.2-80

SRAH Heat Recovery versus Run Time for the April Test Period

Exhibit 2.2-81 is a photograph of the SRAH panel taken from below and inside of the furnace following the April test period. The photograph shows the damage to the small upper tile (lower left corner) and the upper right middle tile (right edge) and indicates that the ceramic tiles are coated to a significant degree with a layer of slag/refractory. Also, some furnace refractory damage is evident above the SRAH panel, indicating that furnace refractory was contributing to the slag running down the surface of the SRAH tiles/bricks. This furnace refractory damage was repaired prior to the June test period. Exhibit 2.2-81 shows areas where patches of slag/refractory scale were removed from the surface of the ceramic tiles. However, most of the slag/refractory was tightly bonded to the ceramic tile surface. 


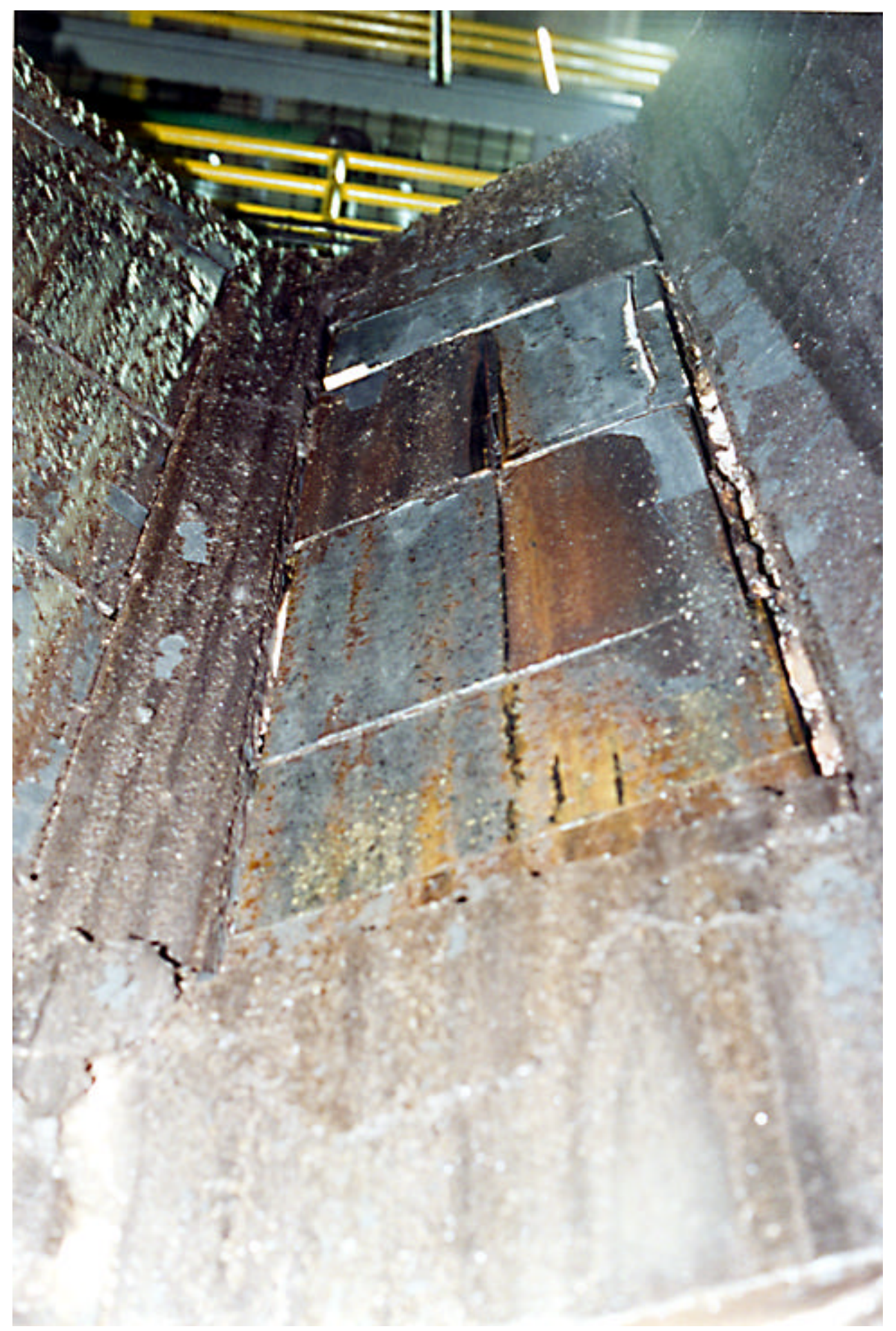

Exhibit 2.2-81

Photograph of the SRAH Panel from Inside of the Furnace after the April Test Period

Exhibit 2.2-82 summarizes the SRAH ceramic tile temperatures for the June test. The ceramic tile surface temperatures ranged from nominally 1540 to $2570^{\circ} \mathrm{F}\left(838\right.$ to $\left.1410^{\circ} \mathrm{C}\right)$ when the SFS 
was fired on Center lignite at 100\% load (Run Hours 26 through 50 and 60 through 76). As previously observed, the highest tile surface temperatures were generally measured at or near the furnace side of the tiles. Lower tile temperatures were measured on the back or cavity surface of the tiles or in the cavity.

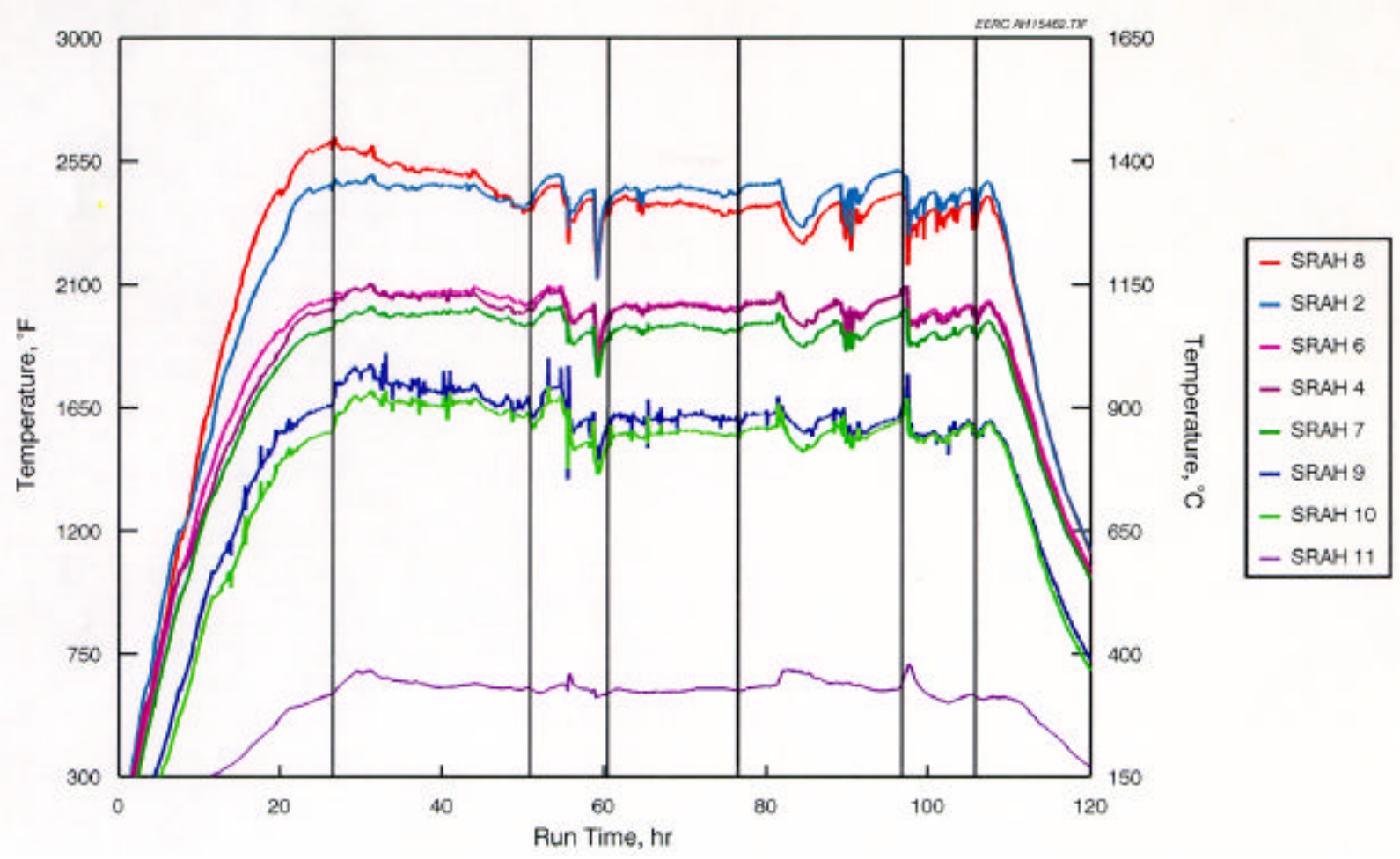

Exhibit 2.2-82

SRAH Ceramic Tile Temperatures versus Run Time for the June Test Period

The ceramic tile temperature variability shown in Exhibit 2.2-82 is a direct result of furnace operating conditions since the SRAH panel cooling is accomplished with water rather than air. Cooling water flow rates were adjusted to control water exit temperature at $<140^{\circ} \mathrm{F}\left(60^{\circ} \mathrm{C}\right)$. The total cooling water flow rate during the June test period was nominally 6 gal $/ \mathrm{min}(23 \mathrm{~L} / \mathrm{min})$.

Heat recovery data from the SRAH panel are presented in Exhibit 2.2-83 for the June test period. The SRAH heat recovery during the June test period does not appear to decrease with time during the lignite-fired test periods. Nominal values ranged from 97,000 to $119,000 \mathrm{Btu} / \mathrm{hr}$ $(102,200$ to $125,400 \mathrm{~kJ} / \mathrm{hr})$. The main burner firing rate was nominally 2.5 to $2.6 \mathrm{MMBtu} / \mathrm{hr}(2.6$ to $2.7 \times 10^{6} \mathrm{~kJ} / \mathrm{hr}$ ). The firing rate distribution between the main and auxiliary burners was $78 \%-79 \%$ main and $21 \%-22 \%$ auxiliary. No attempt was made to adjust the firing rate distribution between the main and auxiliary because of ash deposition and slag flow problems. 


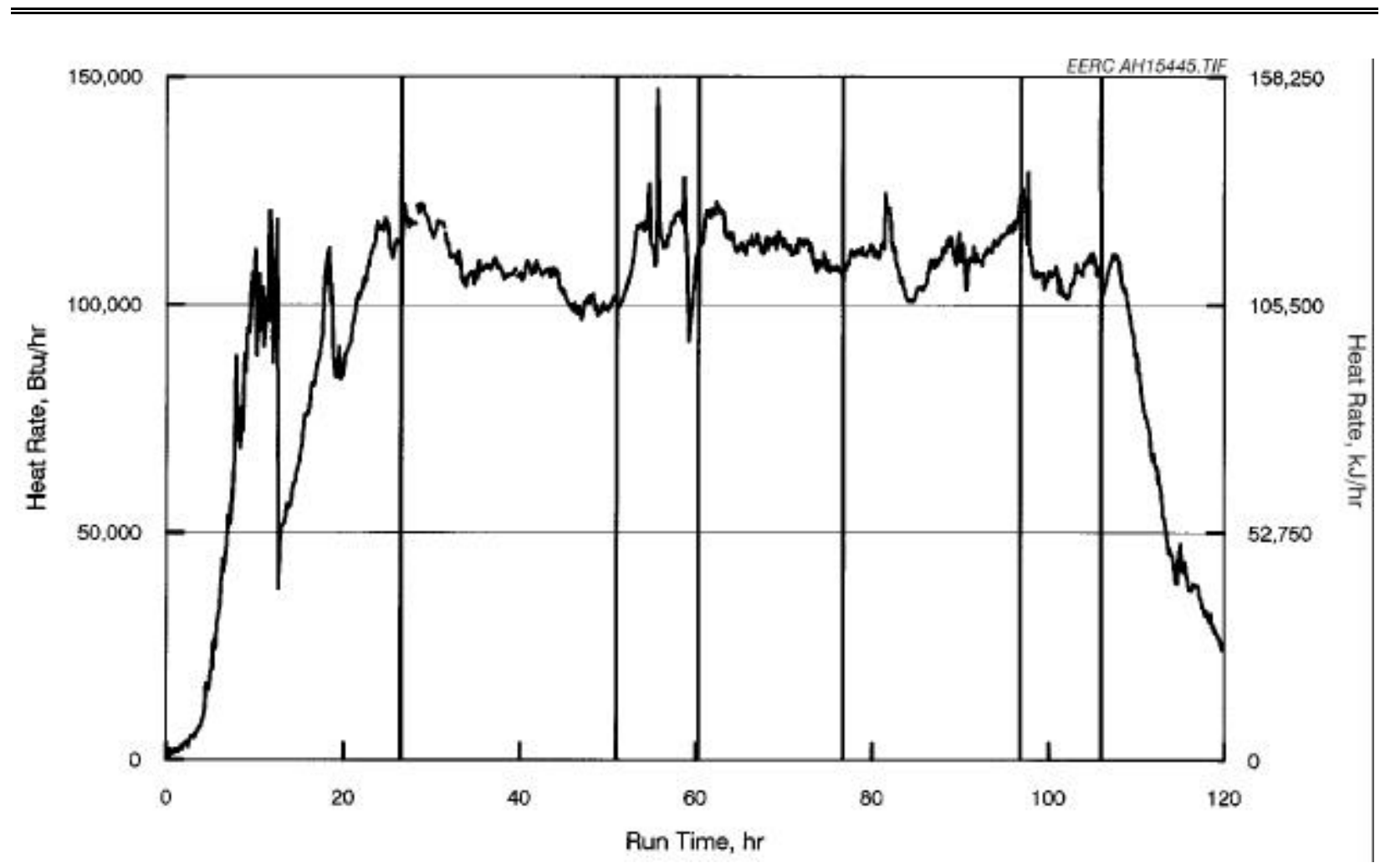

Exhibit 2.2-83

SRAH Heat Recovery versus Run Time for the June Test Period

As expected, temperatures were very constant for individual test periods once furnace conditions were stabilized. SFS stability was better when firing the Center lignite because the fuel feed was more stable when compared to the Coal Creek-Falkirk lignite (high surface moisture). Comparison of the SRAH panel heat recovery data for the April (Coal Creek-Falkirk lignite) and June (Center lignite) test periods indicates that overall heat recovery was slightly greater in June than in April even though the average lignite firing rates were similar. One possible explanation for the lower SRAH heat recovery in April may be a lower flame intensity because of a slightly higher moisture content. Another possibility may be that the flame in June was more emissive because of the larger amount of vaporized inorganics from the Center lignite.

Exhibit 2.2-74 shows the SRAH panel following the June test period. All of the individual ceramic tiles/bricks appear to be intact. The only visible crack in the photograph is the horizontal one across the upper right middle tile. Other cracks present in the tiles/bricks are not evident in the photograph but are illustrated in Exhibit 2.2-76. Exhibit 2.2-74 shows the entire LRAH and SRAH panels, indicates that the SRAH ceramic tiles/bricks are almost entirely coated with a slag/refractory layer, and that slag is dripping from one tile/brick to the next and off of the small bottom support brick onto the furnace refractory. There is also evidence of slag/refractory running down the furnace wall to the slag tap below the lower right corner of the SRAH panel. Furnace refractory damage above the RAH panels is evident in the photograph. 


\section{HITAF Air Heater Materials}

\section{Refractory Materials for the Radiant Air Heaters}

During this reporting period, the work at UTRC on the refractory materials for the radiant air heater was focussed on testing the mechanical properties of a new refractory material. This material was developed by Monofrax Inc. and was tailored specifically to have optimized properties, (thermal conductivity, emissivity, slag resistance and good mechanical properties at elevated temperatures) for application as the hot lining material in the RAH. In this report, the results of flexure tests performed on the new material are presented.

A second activity was an analysis and evaluation of a fused cast refractory tile, which went through several runs in the pilot test facility at the University of Dakota Energy and Environmental Research Facility. The microstructural changes in a high alumina, fused-cast tile (Monofrax M) due to reactions with the hot coal slag are discussed.

\section{Flexure Strength and Modulus of ACF-10.}

Several experimental compositions of fused cast refractories for the large RAH radiation tiles (hot lining) were developed by Monofrax Inc. Slag tests performed at Monofrax Inc., showed that the ACF-10 composition had far superior corrosion resistance to the Illinois slag over the other compositions developed. It also had a high emissivity and relatively high thermal conductivity, which was reported in the Fourth Quarterly Report of 1997. However, the key to further development and RAH testing depends on whether the mechanical properties are adequate at temperatures up to $1371^{\circ} \mathrm{C}\left(2500^{\circ} \mathrm{F}\right)$. Over 20 flexural specimens, $101.6 \mathrm{~mm}$ long x $12.7 \mathrm{~mm}$ wide (4" long $x{ }^{1 / 2}$ " wide), were machined from a slab of fusion-cast ACF-10. The samples were tested at various temperatures up to $1371{ }^{\circ} \mathrm{C}$. They were heated at $10^{\circ} \mathrm{C} / \mathrm{min}$ to the test temperature, and then held for 15 min prior to 4-point flex testing. The thickness of the specimen was purposely varied from 0.100 to $0.183 \mathrm{~mm}$ to see if it had an effect on the strength, but none was found.

The strength and elastic modulus are shown in Exhibit 2.2-84, along with the values for other fused-cast materials tested earlier. The ACF-10 material is as strong as Monofrax L (spinel composition) and Monofrax K-3 (alumina chromia) at room temperature and at $982^{\circ} \mathrm{C}$, and has good strength at $1371^{\circ} \mathrm{C}$. The ACF- 10 material has superior strength to the Monofrax M at all temperatures. Monofrax $\mathrm{M}$ tiles are currently being tested in the large and small RAH test rig at EERC. The Monofrax L tiles are being tested in only the small RAH. 


\begin{tabular}{|c|c|c|c|c|c|c|c|}
\hline \multicolumn{8}{|c|}{$\begin{array}{c}\text { Exhibit 2.2-84 } \\
\text { Flexural Strength and Modulus of Fusion Cast Refractories } \\
\text { at Various Temperatures }\end{array}$} \\
\hline & & \multicolumn{6}{|c|}{ Test Temperature $\left({ }^{\circ} \mathrm{F}\right)\left[{ }^{\circ} \mathrm{C}\right]$} \\
\hline \multirow{2}{*}{\multicolumn{2}{|c|}{ Material Test Results }} & RT & (1800) & (2000) & (2200) & (2400) & (2500) \\
\hline & & RT & [982] & [1093] & [1204] & [1316] & [1371] \\
\hline \multirow[t]{2}{*}{ Monofrax M } & Strength (ksi) & 3.2 & 2.8 & -- & 2.5 & --- & 2.3 \\
\hline & E (Msi) & 24.7 & 20.9 & --- & 20.4 & --- & 12.4 \\
\hline \multirow[t]{2}{*}{ Monofrax L } & Strength (ksi) & 8.3 & --- & 6.3 & 5.9 & --- & 5.2 \\
\hline & E (Msi) & 25.4 & -- & 19.0 & 18.0 & --- & 16.4 \\
\hline \multirow[t]{2}{*}{ Monofrax K-3 } & Strength (ksi) & 8.9 & 6.5 & --- & --- & 2.1 & --- \\
\hline & E (Msi) & 21.1 & 8.9 & --- & $\begin{array}{c}7.6 \\
(2100)\end{array}$ & 5.3 & --- \\
\hline \multirow{2}{*}{$\begin{array}{l}\text { ACF-10 } \\
\text { (experimental) }\end{array}$} & Strength (ksi) & 8.2 & 6.9 & 6.5 & 6.4 & --- & 3.0 \\
\hline & E (Msi) & 22.7 & - & $-\ldots$ & 16.5 & - & 10.6 \\
\hline
\end{tabular}

The effect of temperature on the elastic modulus of ACF-10 is compared with that of Monofrax L, M, and $\mathrm{K}$ in Exhibit 2.2-85. Its elastic modulus is close to that of Monofrax L and $\mathrm{M}$, and is clearly greater than that of the Monofrax K-3 over the entire test temperature range. 


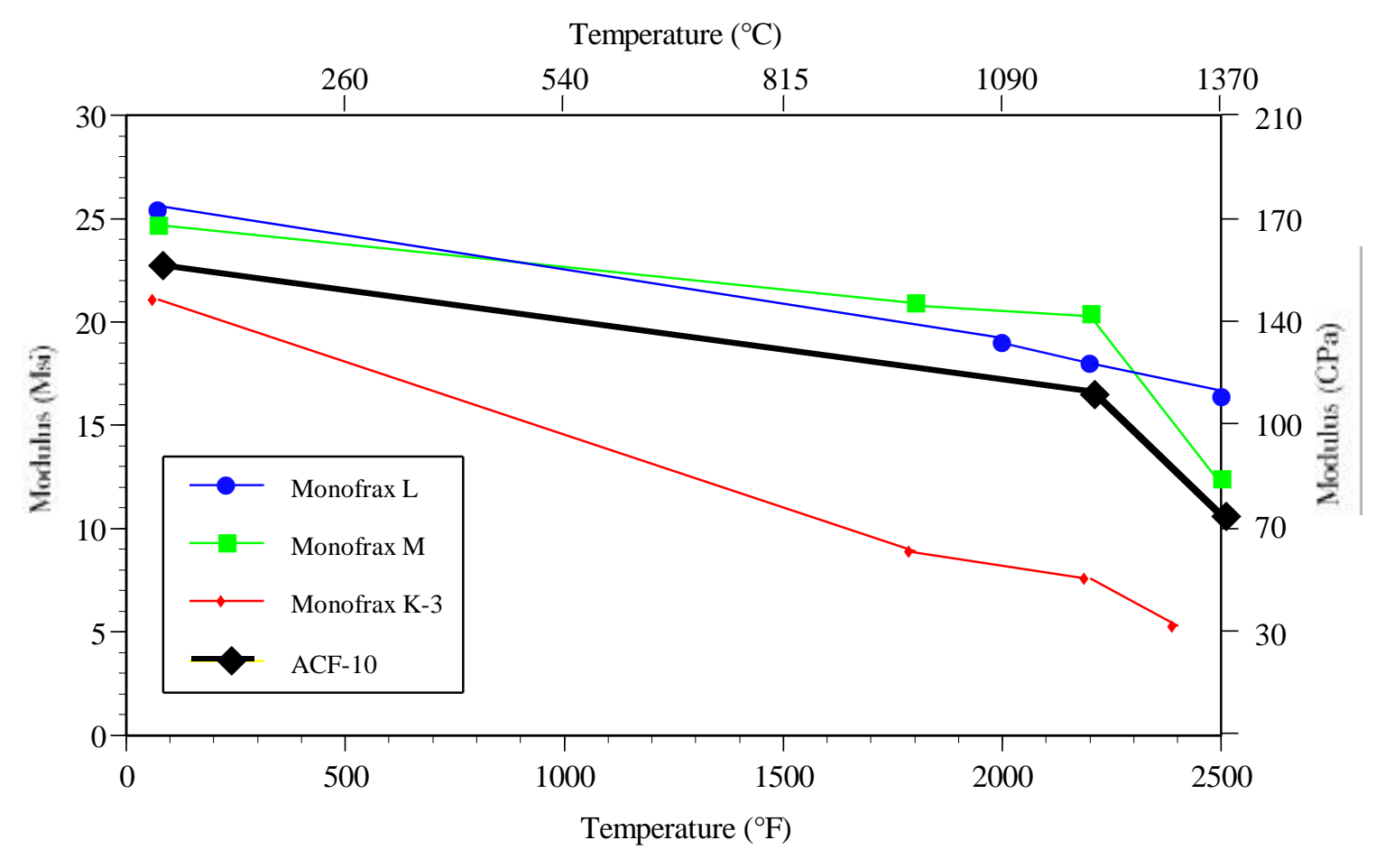

Exhibit 2.2-85

Effect of Temperature on Elastic Modulus of Monofrax L, Monofrax M, Monofrax $\mathrm{K}-3$, and ACF-10 (experimental).

The four point flexural strength of the ACF-10 material is compared with that of the Monofrax L, M, and K materials in Exhibit 2.2-86. The ACF-10 material retains its strength to $1371^{\circ} \mathrm{C}\left(2500^{\circ} \mathrm{F}\right)$, and at this temperature is stronger than the Monofrax $\mathrm{M}$ and $\mathrm{K}-3$, which indicates that it has adequate strength for use as radiation tiles in the RAH. 


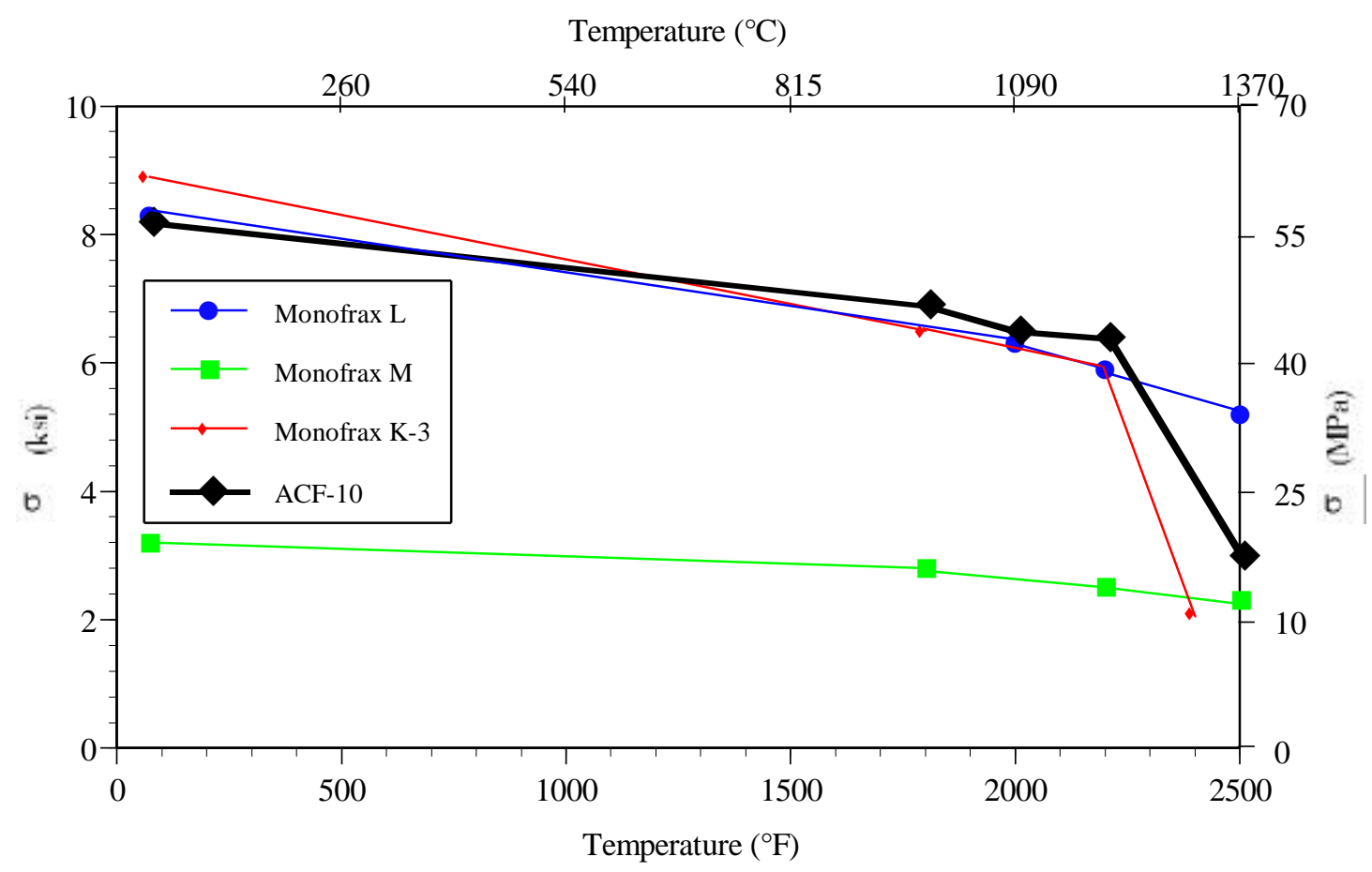

\section{Exhibit 2.2-86 \\ Effect of Temperature on 4-point Flexural Strength of Monofrax L, Monofrax M, Monofrax K-3, and ACF-10 (experimental).}

\section{Characterization and Evaluation of Monofrax $\underline{M}$ Tile}

After the fourth run in the UNDEERC Pilot Test Facility, the top Monofrax top tile in the large RAH had fractured through the middle. It was then removed and replaced with another tile. The removed tile had been exposed to:

- 104 hours of firing conditions under natural gas (run 1);

- 140 hours of firing Illinois \# 6 coal plus 86 hours of gas firing (runs 2 and 3); and

- 32 hours of subbituminous coal (Rochelle) plus 81 hours of gas firing (run 4).

The flame temperatures that the tile was exposed to were in the range of $1427^{\circ}-1482^{\circ} \mathrm{C}$ $\left(2600^{\circ}-2700^{\circ} \mathrm{F}\right)$, and the front (hot) face temperature was of the order of $1371^{\circ} \mathrm{C}\left(2500^{\circ} \mathrm{F}\right)$. The slag of the Illinois \#6 coal is fluid under the test conditions at temperatures in the $1343^{\circ}-1371^{\circ} \mathrm{C}$ $\left(2450^{\circ}-2500^{\circ} \mathrm{F}\right)$ range according to EERC personnel. Inspection of the residual slag on the tile indicated that it had been fully in the liquid state. The back face temperature of the tile was estimated to be in the $1093^{\circ}-1149^{\circ} \mathrm{C}\left(2000^{\circ}-2100^{\circ} \mathrm{F}\right)$ range, which is based on the back face thermocouple data from the center of an adjacent tile. It therefore appears that the thermal gradient through the tile from the hot face is of the order of $250^{\circ} \mathrm{C}\left(450^{\circ} \mathrm{F}\right)$.

Photos of the Monofrax M tile that was returned to UTRC are shown in Exhibit 2.2-87. The hot face exposed to the slag appears black, and the rear face, which was originally white, shows a pink to red coloration. This coloration is due to the chromium vapor that was released by the adjacent chromium-containing Aurex 30 support bricks. The chromium reacts with the alumina to form a ruby color. Small amounts of chromium $(<1 \%)$ are sufficient to produce the color. 


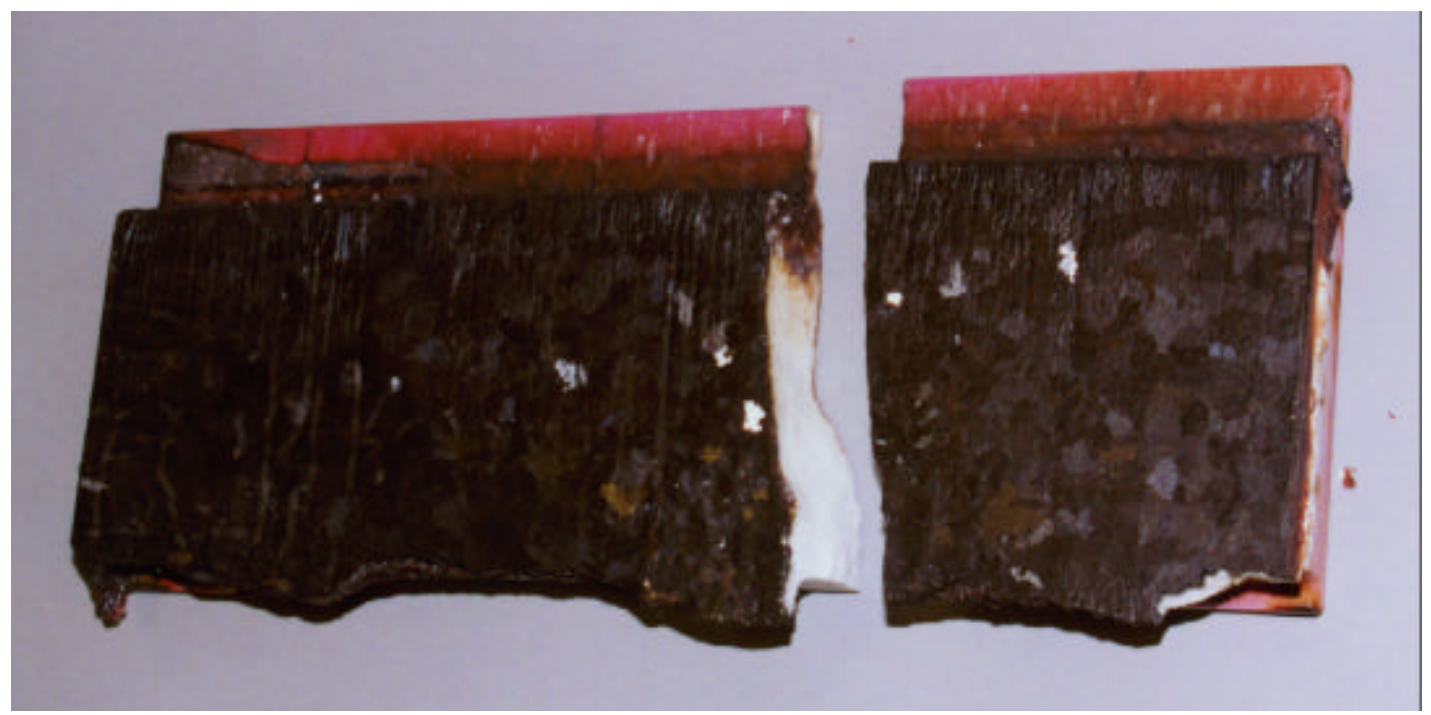

(a)

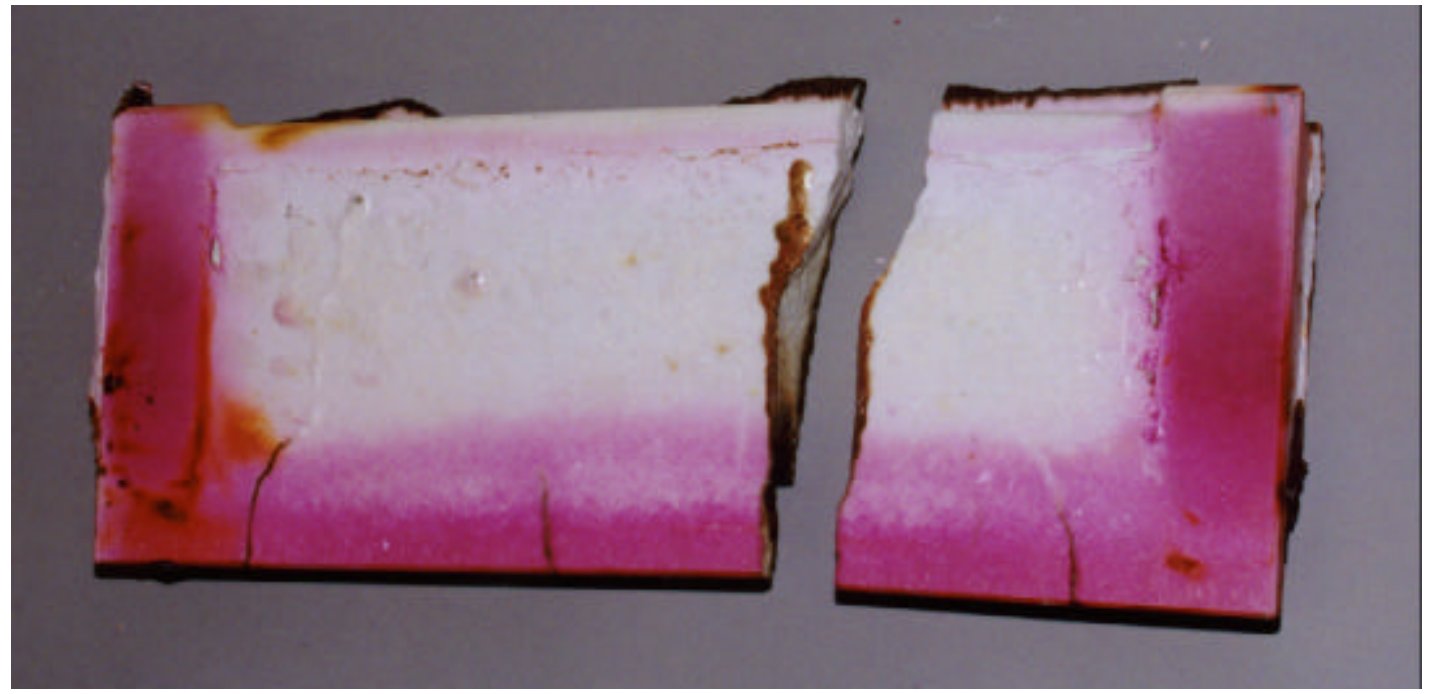

(b)

\section{Exhibit 2.2-87 \\ Hot face $[A]$ and Cool Face [B] of Monofrax M Large-RAH Top Tile (Removed after 4 runs in UNDEERC Test Facility)}

A vertical slice was cut through the tile to show how far the slag had penetrated and reacted with the alumina tile. The penetration of the fluid slag (dark rim) along the vertical surface (Exhibit 2.2-88A) was about $5-6 \mathrm{~mm}(0.20-0.24$ ") into the tile. The slag also penetrated along the top surface of the tile, which was slotted to fit under a mating section of an Aurex 30 top (lintel) piece. 


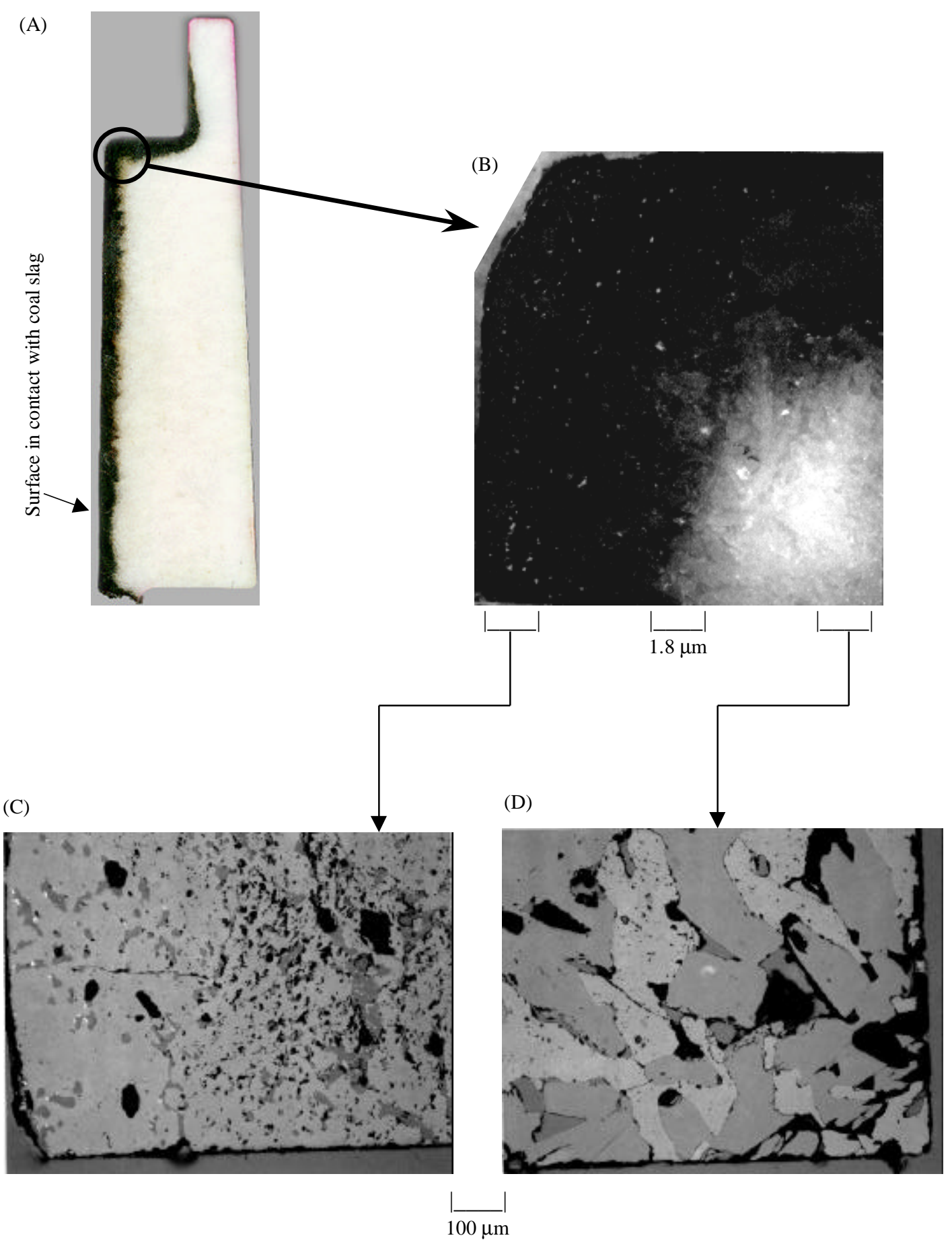

Exhibit 2.2-88

Vertical Cross-Section of Monofrax Top Tile Shown in Exhibit 2.2-87

(Section [A] vertical cross-section; Section [B] cut from tile; microstructure of dark [C] and white $[D]$ regions) 
Exhibit 2.2-88C shows the microstructure of an enlarged view of the darkened (slagpenetrated) region, and Exhibit 2.2-88D shows the microstructure of the white region, which had not been penetrated by the slag. The main difference between the two microstructures is that the $\alpha$ and $\beta$ grains of alumina, which comprise $98 \%$ of the bulk of Monofrax M, can be seen clearly in the unreacted material (Exhibit 2.2-88D). In the penetrated region (Exhibit 2.2-88C), many of the voids and microcracks have been filled with the slag, so that the original grain boundary regions become concealed. However, it does not appear that the $\alpha$ and $\beta$ alumina grains have been attacked or corroded by the slag, which should become evident from examining Exhibits 2.2-88 through 2.2-92.

Exhibit 2.2-89 shows the microstructure of two vertical sections photographed through the sample shown in Exhibit 2.2-88B. The region separating the unreacted alumina from that penetrated with the slag is marked with a dividing line. In the left photograph, where the slag has penetrated from two directions, the microstructure appears to have a rougher, more pitted texture than in the comparable region of the right photograph. In the right photograph, the $\alpha$ and $\beta$ grains can still be delineated.

Greater microstructural features can be seen in Exhibit 2.2-90, which show regions (Photos 1, 2, and 3) in the slag penetrated zone of Exhibit 2.2-89, and regions (photos 4, 5, and 6) outside of the slag penetrated zone. Photos 1, 2 and 3 all show the same microstructural features: having finely dispersed second phases and voids. Closer examination reveals that many of the voids have been filled with a darker gray phase, which is the slag. All slag pockets or regions show discrete white particles that are rich in iron, and can be seen in Photo 1 of Exhibit 2.2-90. The iron rich particles often have geometric shapes with triangular or square edges indicating that they precipitated from the slag during cooling, and can be seen in Exhibit 2.2-91, which shows magnified views of Photo 1 of Exhibit 2.2-90. As the distance from the slag surface increases, the number of slag pockets decreases (Photos $2 \& 3$, of Exhibit 2.2-90) unless there are cracks in the Monofrax $\mathrm{M}$ that originate in the surface and penetrate more deeply into the interior regions (of Exhibit 2.2-89). These cracks provide a conduit for the slag to penetrate more deeply into the Monofrax M.

Photos 4, 5 and 6 of Exhibit 2.2-90, were taken at increasing depths from the slag surface, and all were within the white (unaltered) region of the Monofrax M tile. However, close examination reveals only very few small pockets of slag that were fed from nearby cracks containing slag (of Exhibit 2.2-89). However, the quantity of slag was so low that any discoloration of the white Monofrax $\mathrm{M}$ was not visible.

Electron probe photographs and element maps were taken in the three regions (A, B, and C) of the sample shown in Exhibit 2.2-89. In Exhibit 2.2-92, a cross-section of the sample surface in contact with the slag is shown, where a crack is visible. The back scattered electron image shows that this crack has been filled with a material that contains the white angular particles seen previous exhibits. The elemental maps show that this material is rich in silicon, iron, oxygen, and calcium, which are the main constituents in the slag. Aluminum is also present (blue region) but is not at as a high a concentration as in the surrounding alumina particles $\left(98 \% \mathrm{Al}_{2} \mathrm{O}_{3}\right.$, yellow/green region). 

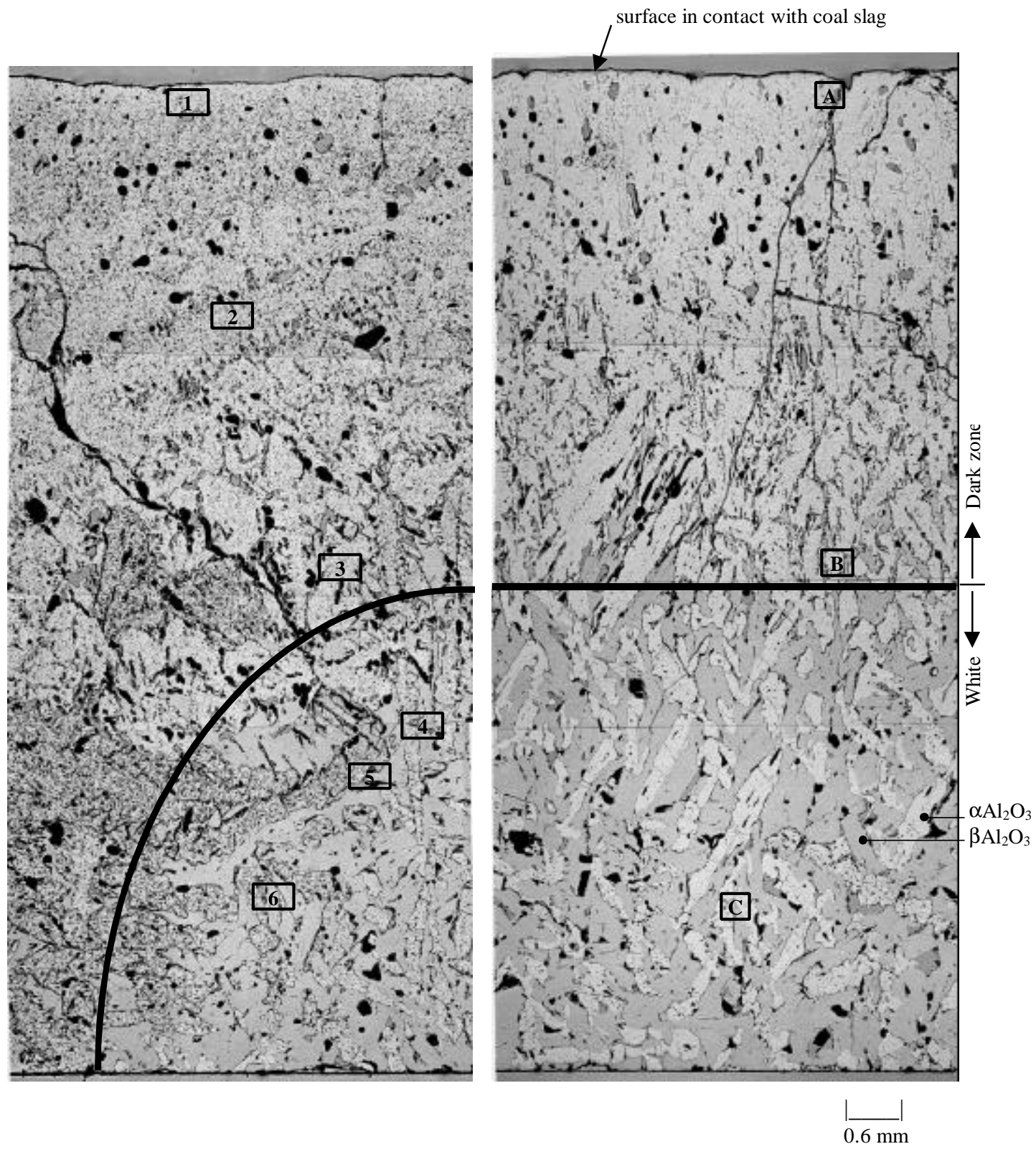

Exhibit 2.2-89

Magnified views of Exhibit 2.2-88B

(Shows changes in Monofrax M microstructure from top (slag surface) to interior, unaltered (white) region.) 
(1)

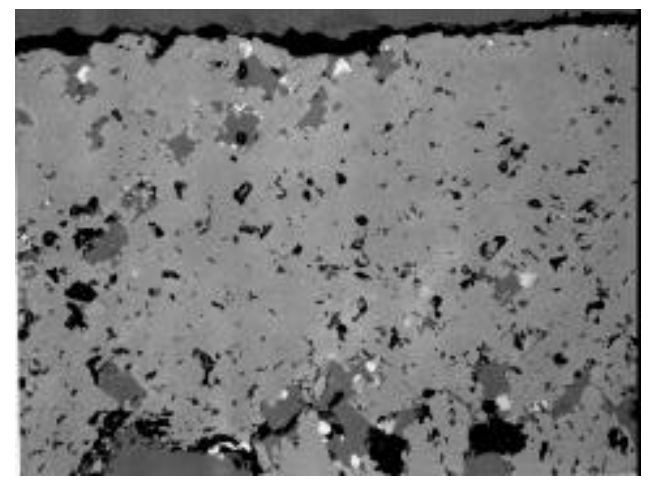

(3)

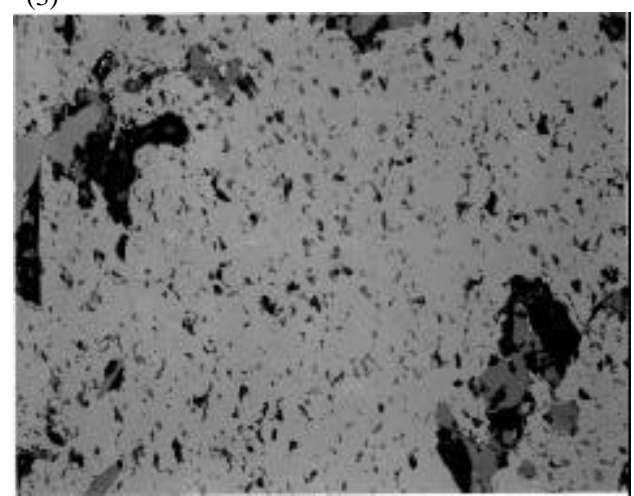

(5)

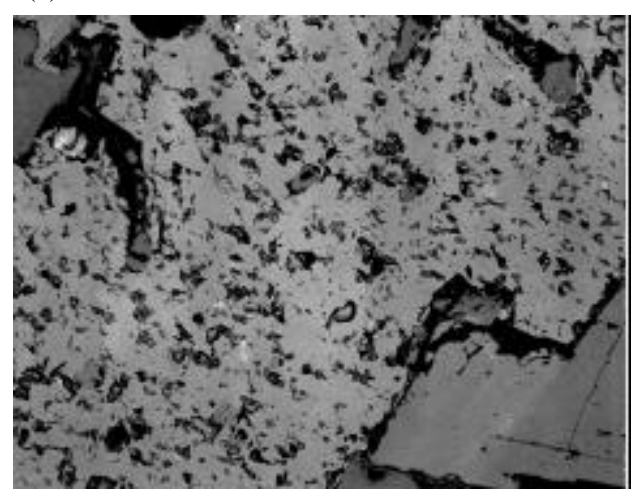

(2)

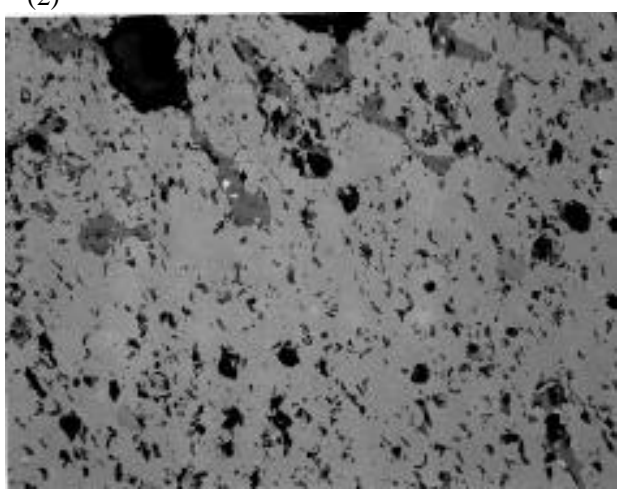

(4)

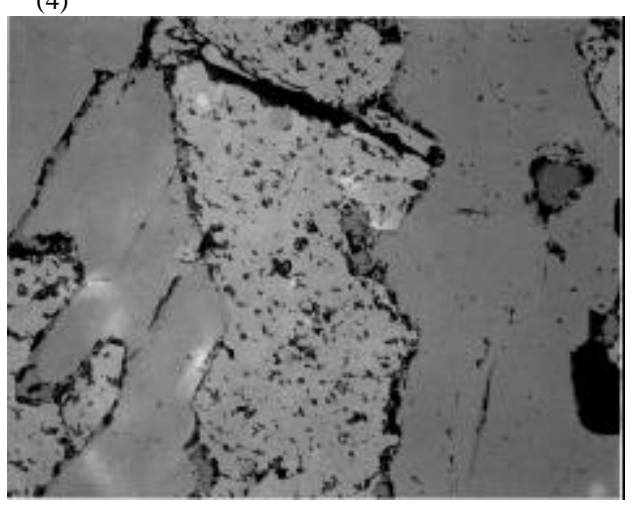

(6)

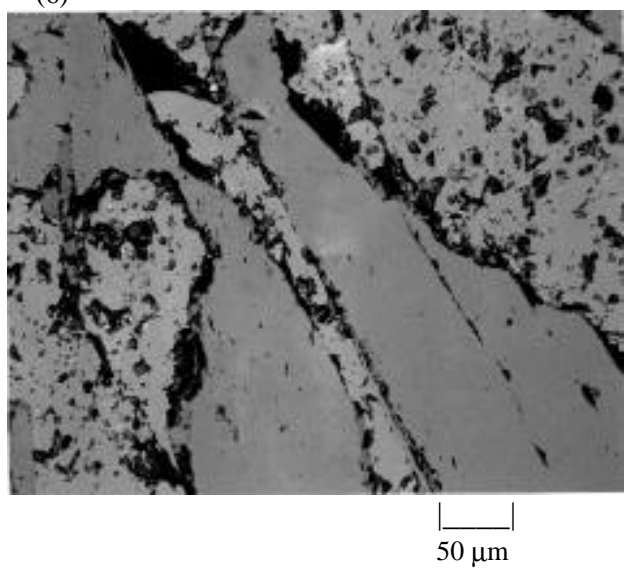

Exhibit 2.2-90

Photomicrographs of Various Regions in Exhibit 2.2-89

(Regions $1-3$ are in darkened zone due to slag penetration; regions $4-6$ are in the unaltered (white) zone.) 

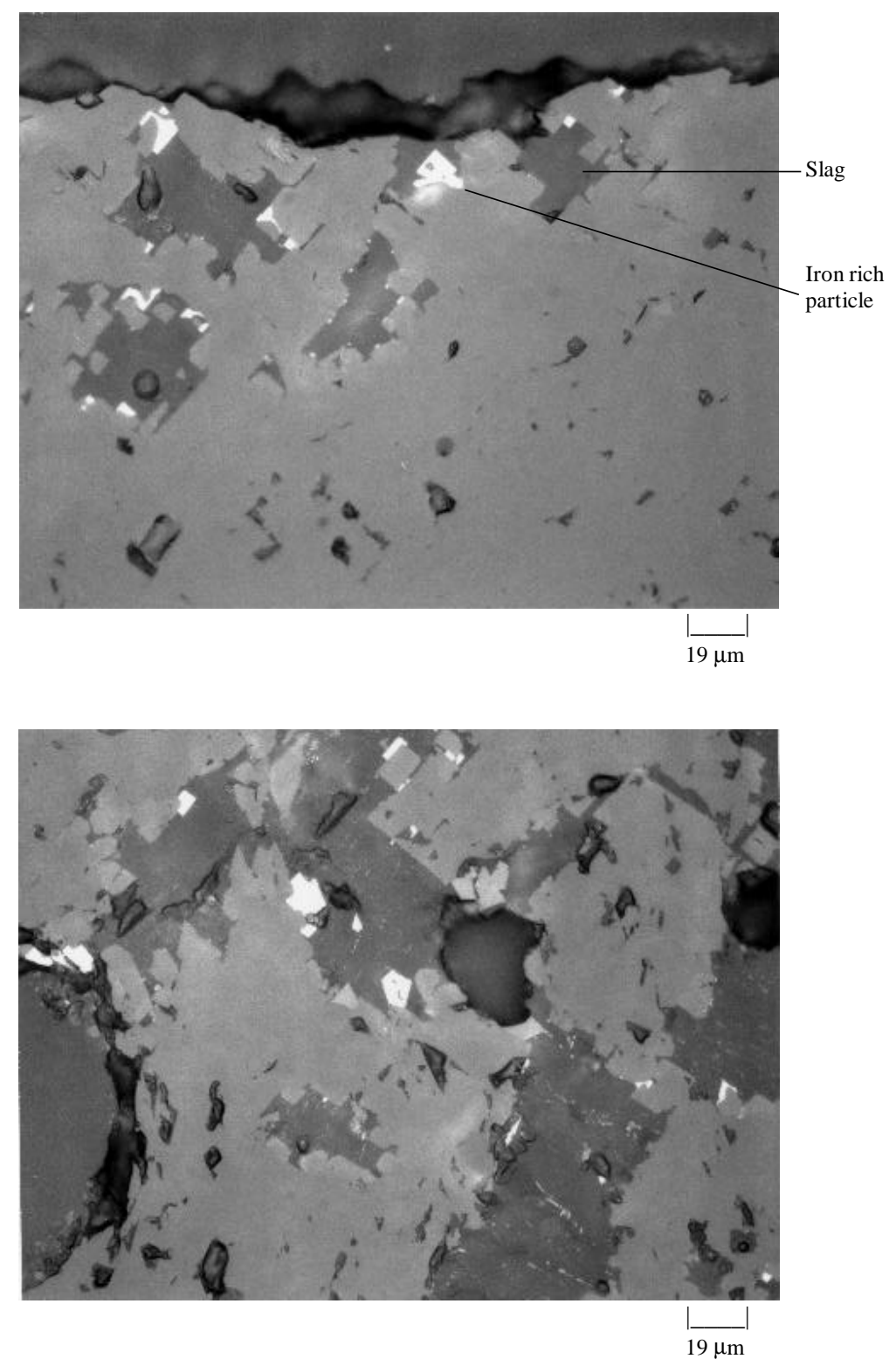

Exhibit 2.2-91

Magnified Views of Slag Pockets in Exhibit 2.2-90 (Slag pockets are dark gray and contain angular iron-rich precipitates (white) 


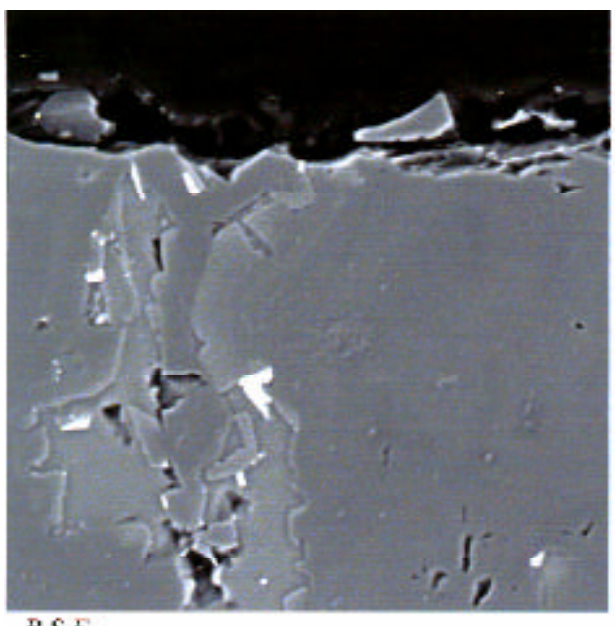

B.S.E.

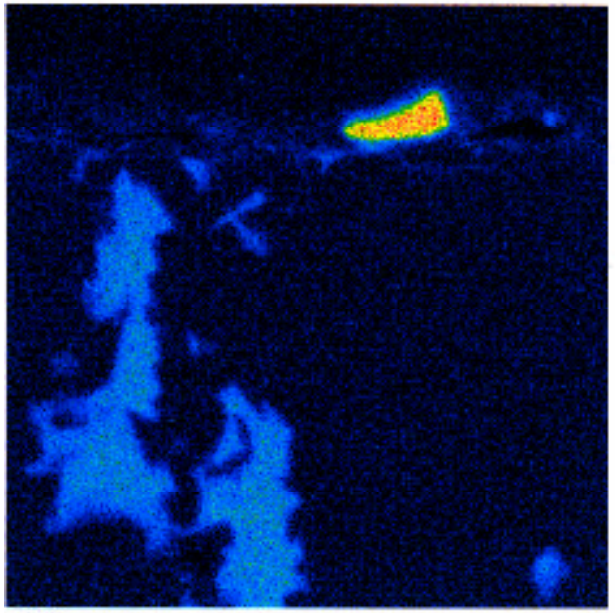

Silicon

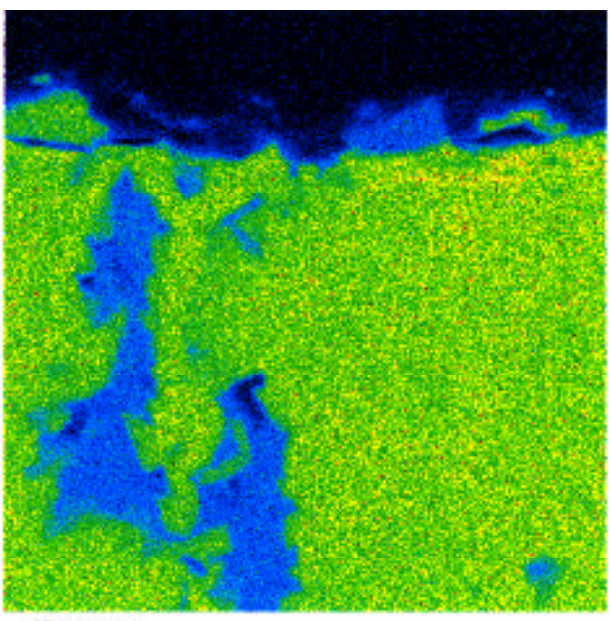

Aluminum

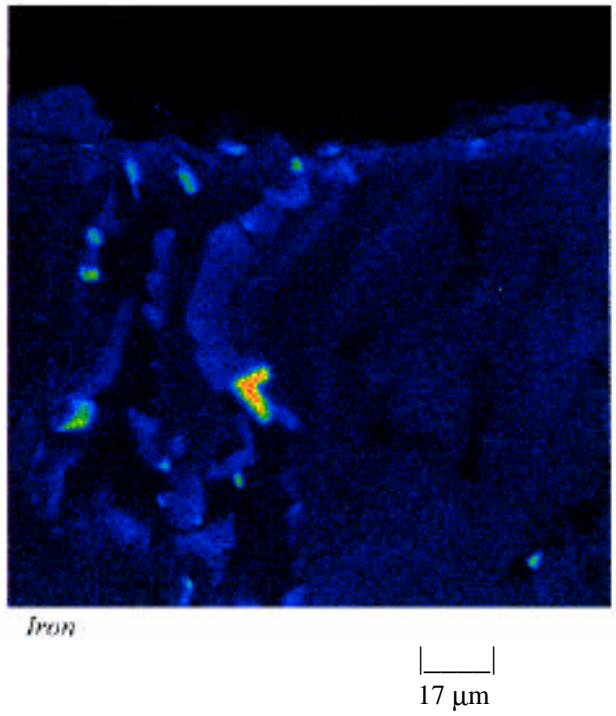

Exhibit 2.2-92

Electron Probe Photomicrographs of (A) in Exhibit 2.2-89

(Displays surface of Monofrax M exposed to slag. Silicon, iron, sodium and calcium rich regions are in the slag, which penetrated the crack.) 


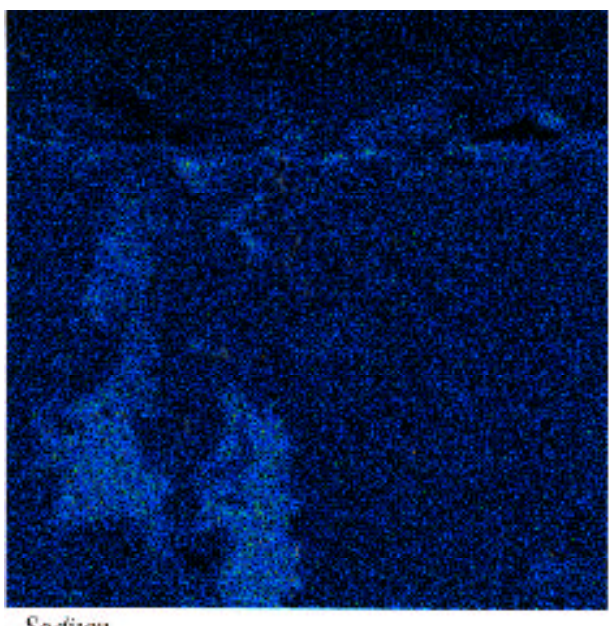

Sodium

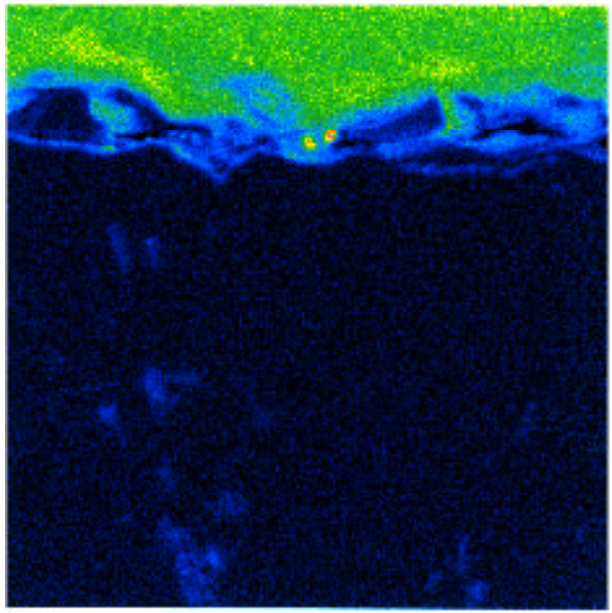

Carion

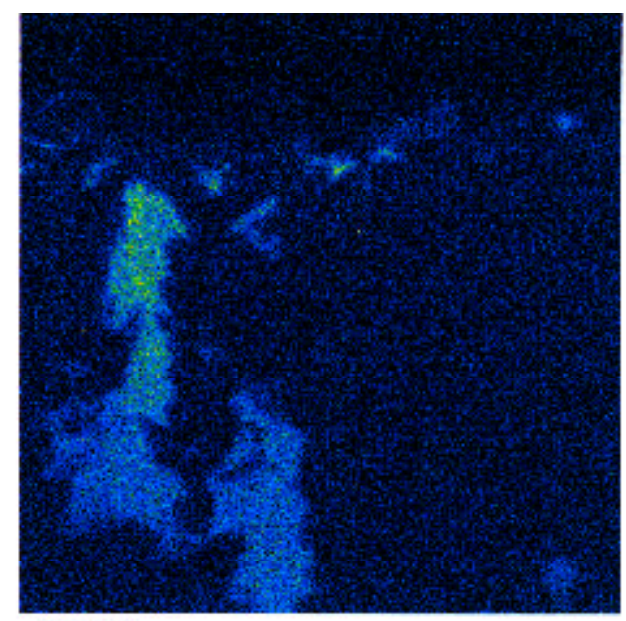

Colcium

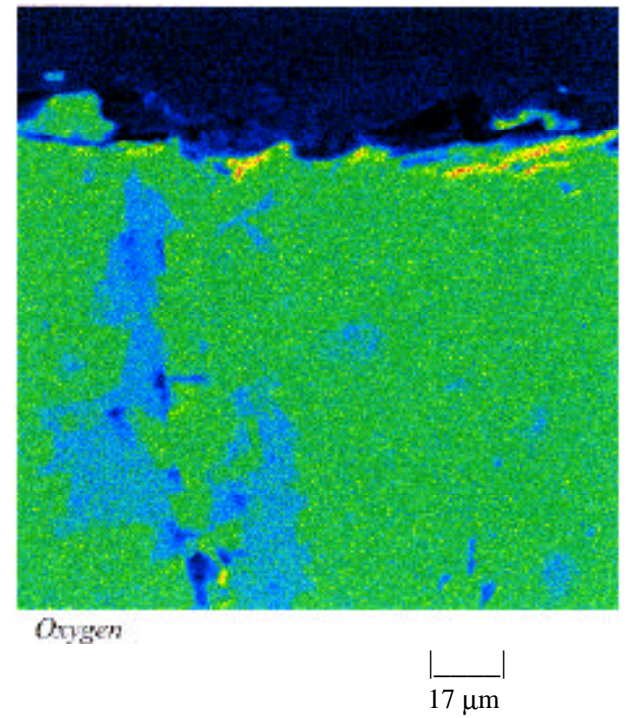

Exhibit 2.2-92 (cont'd)

Electron Probe Photomicrographs of $(\mathrm{A})$ in Exhibit 2.2-89

Exhibit 2.2-93 shows electron probe photomicrographs of region B in Exhibit 2.2-89, which is in a zone near the black/white interface in the Monofrax tile sample. This region is still located in the black or darkened region where the slag has penetrated into the sample, and shows prior voids in the material that are now filled with slag. Again the elemental maps show that the major slag elements are present (aluminum, silicon, iron, sodium, and calcium) in these filled voids. 

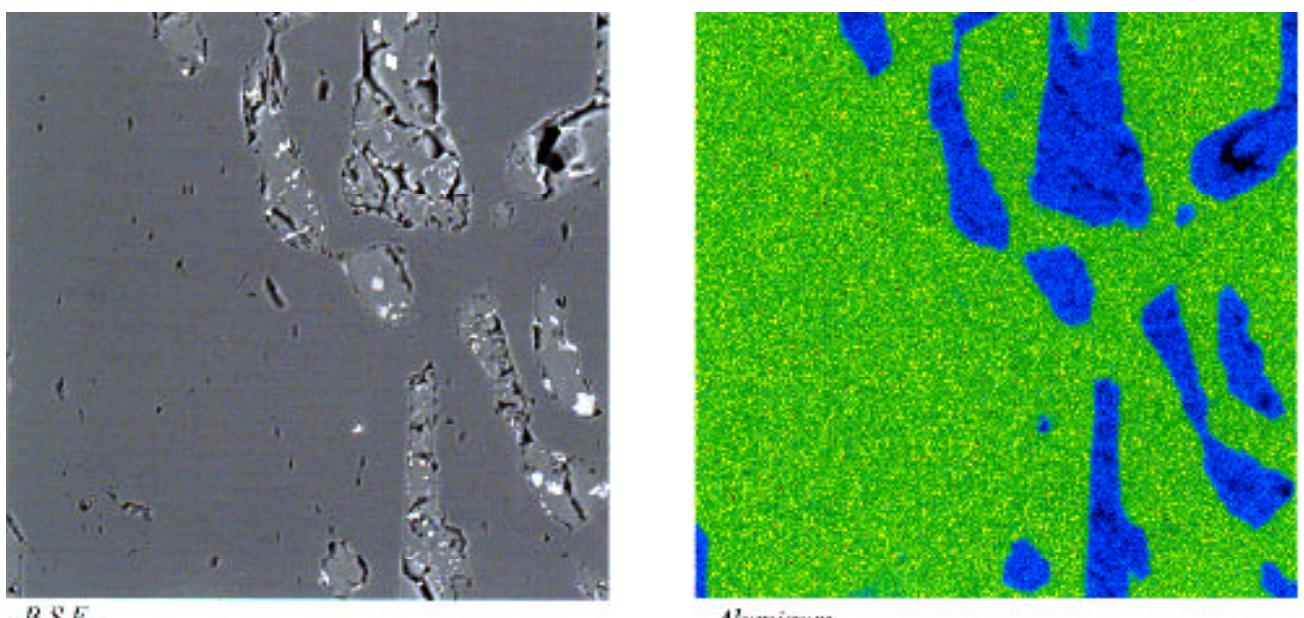

Aluminum

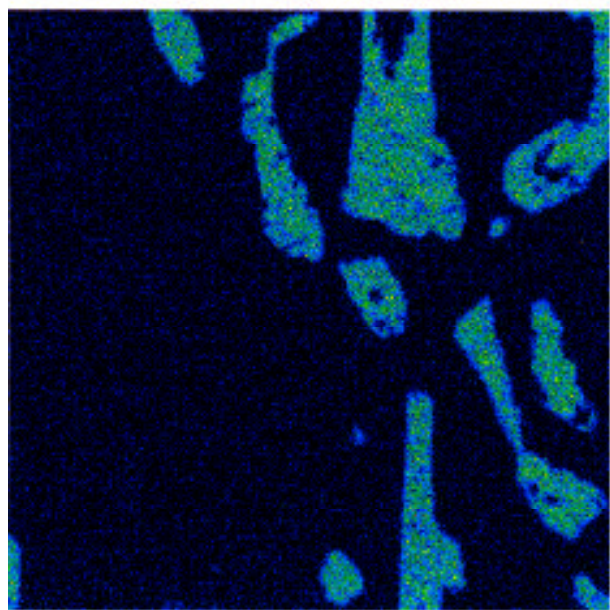

Silicon

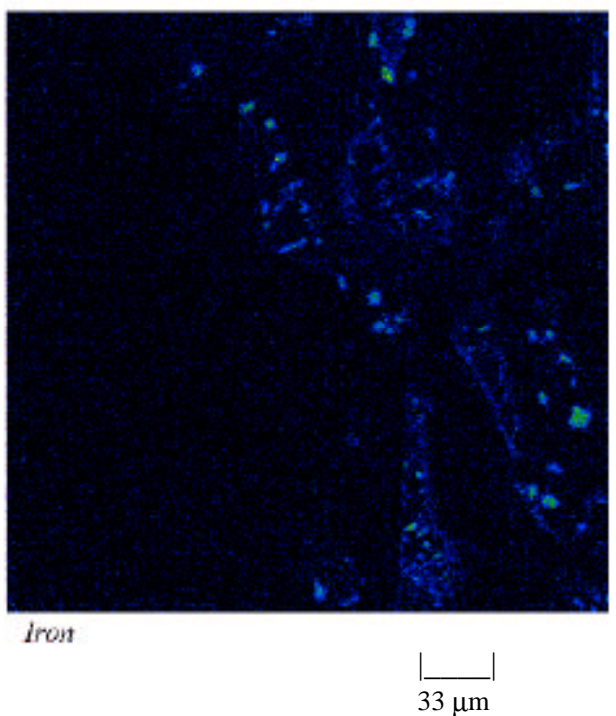

Exhibit 2.2-93

Electron Probe Photomicrographs of (B) in Exhibit 2.2-89

(Displays interior altered (dark)region of Monofrax M. The regions rich in silicon, iron, sodium and calcium have been penetrated by the slag.) 

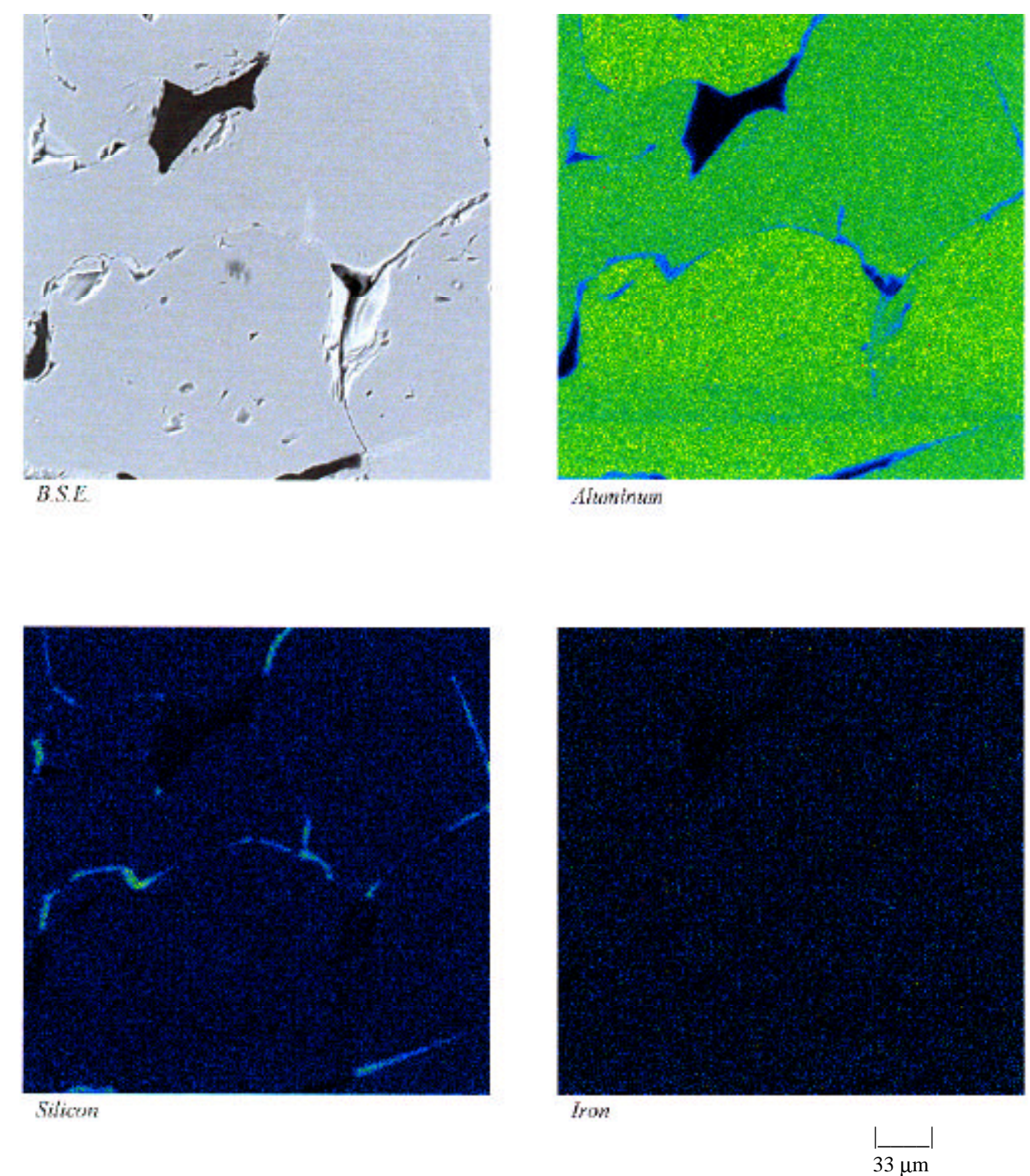

\section{Exhibit 2.2-94}

Electron probe photomicrographs of (C) in Exhibit 2.2-89

(Displays unaltered (white) region of Monofrax M. The silicon and calcium at the grain boundaries is from the Monofrax $M$ and not the slag. Note that there is no iron visible in the iron map. )

The region $\mathrm{C}$ in Exhibit 2.2-89 is located at a depth below the slag penetration, and the electron probe photomicrographs show no evidence of the slag in Exhibit 2.2-94. The silicon and calcium maps show a presence of these elements at the grain boundaries, which is a glassy phase that is present in the original Monofrax $\mathrm{M}$ material. Also, sodium is present in some of the grains, as evident by the sodium element map. This sodium is in the $\beta$-alumina $\left(\mathrm{Na}_{2} \mathrm{O}-11 \mathrm{Al}_{2} \mathrm{O}_{3}\right)$ grains. 


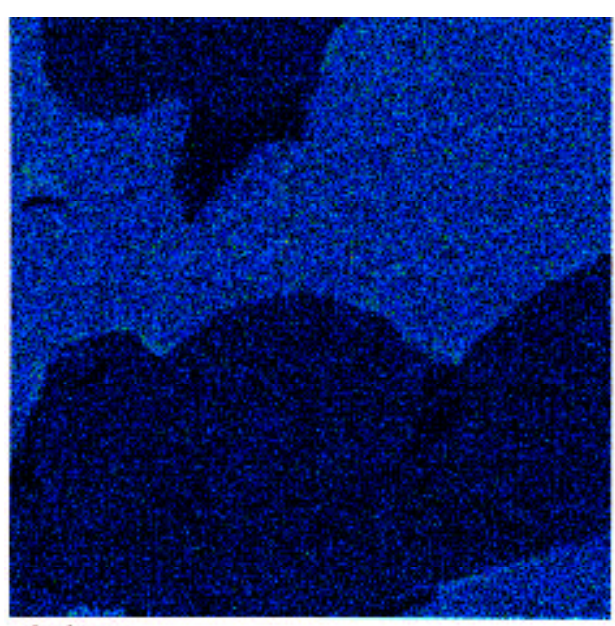

Soditon

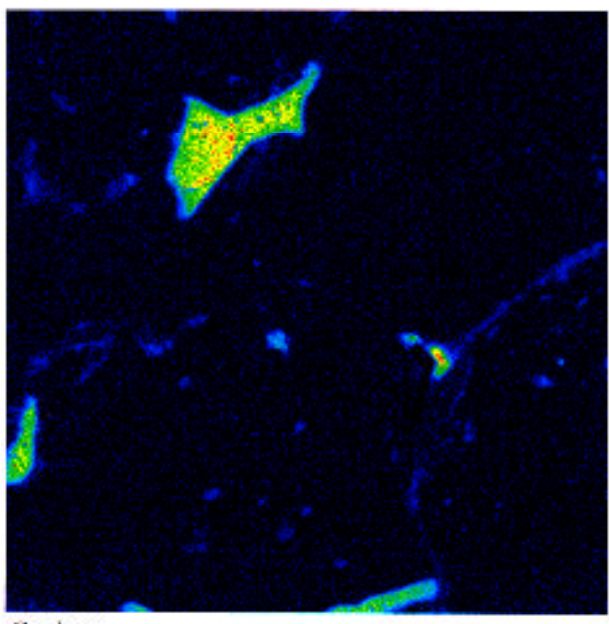

Carbon

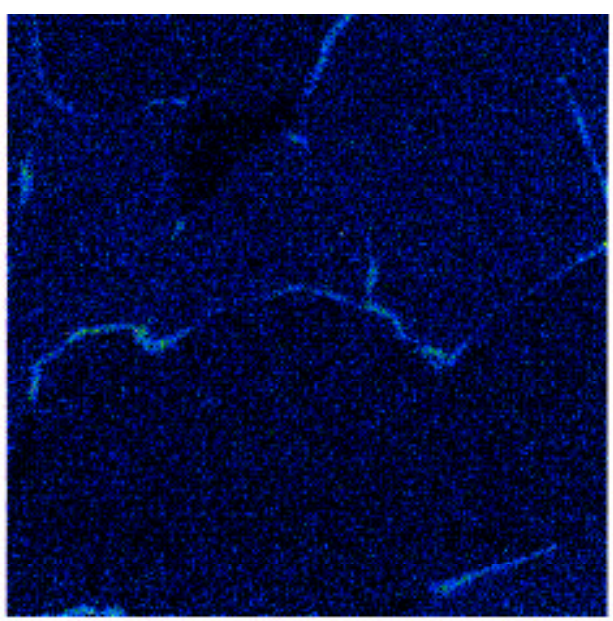

Calcium

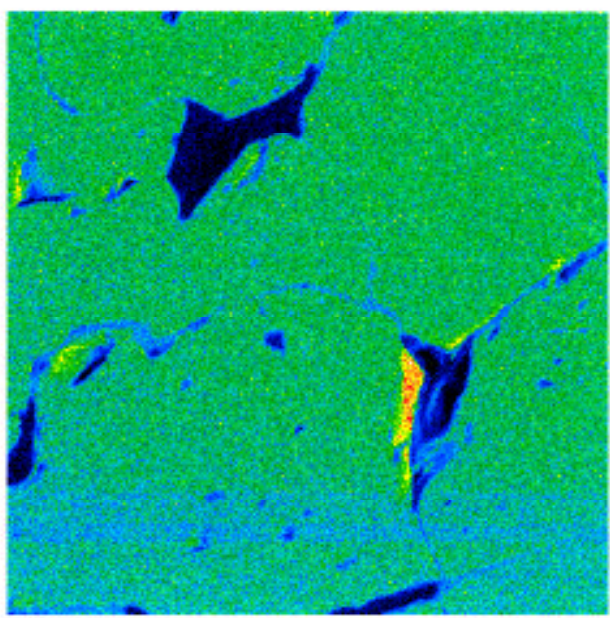

Oxyzen

\section{Exhibit 2.2-94 (cont'd) \\ Electron Probe Photomicrographs of (C) in Exhibit 2.2-89}

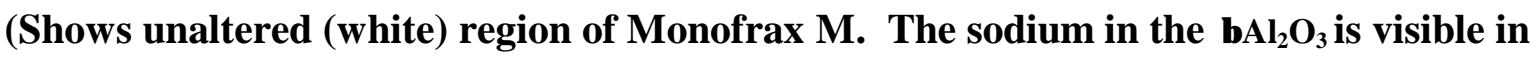
the sodium map above.)

The results of a previous slag test show similar penetration pattern of slag into the Monofrax $\mathrm{M}$ material. In this case, a Monofrax $\mathrm{M}$ crucible was machined out of a fusion cast block of material. It was filled with Illinois \# 6 powdered ash, and then was heated to $1450^{\circ} \mathrm{C}$ for 100 hours in air at Monofrax Inc. Exhibit 2.2-95 shows a cross-section of a portion of the crucible base, where the penetration and discoloration by the molten slag is visible. The original surface is still evident and essentially was not altered, which was the same for the exposed tile sample at the 
pilot test facility at EERC. The voids and cracks in both the crucible and tile material were filled with slag in the dark zone that had been penetrated by the fluid slag.

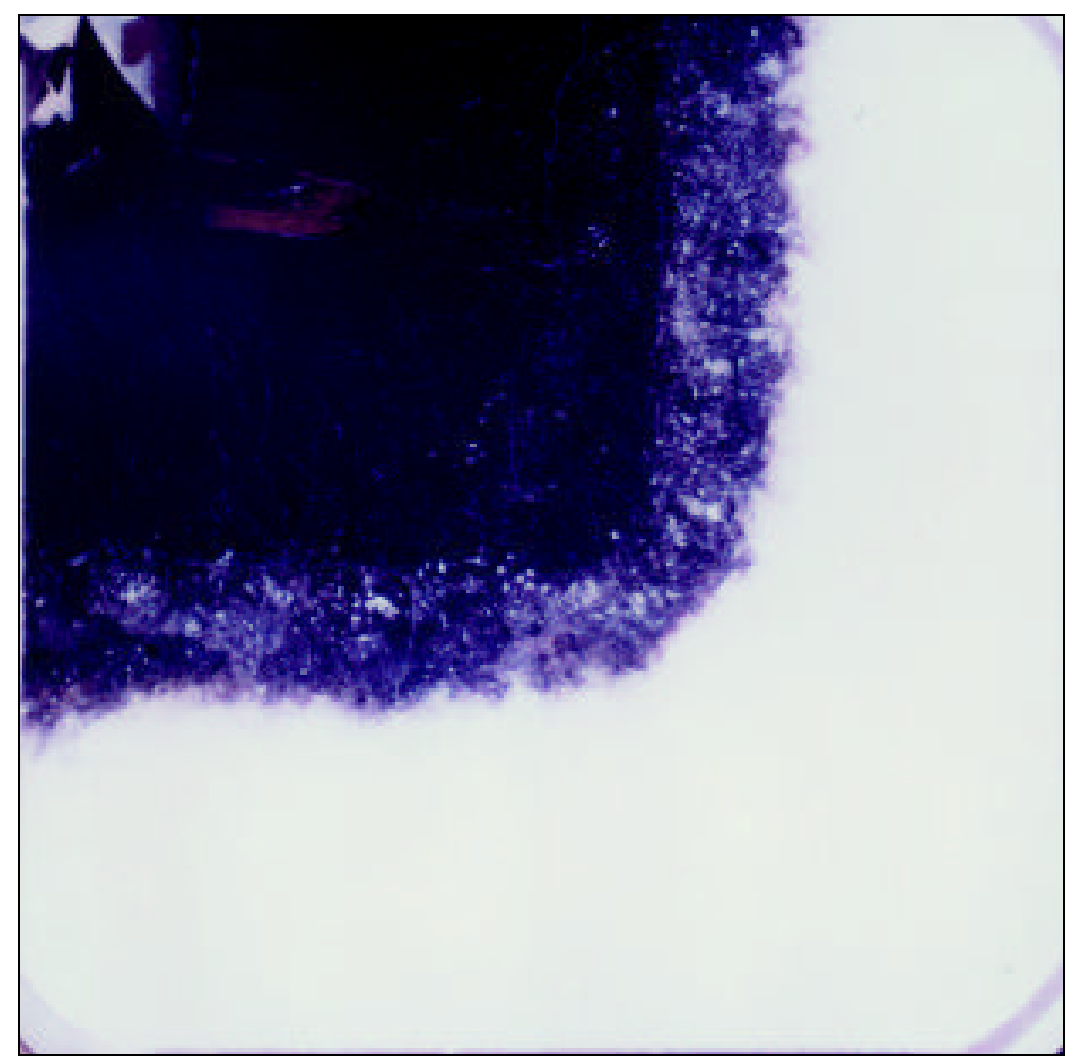

\section{Exhibit 2.2-95}

Cross-section of a Monofrax Crucible Containing Illinois \# 6 Coal Slag after Heating to $1450^{\circ} \mathrm{C}\left(2642^{\circ} \mathrm{F}\right)$ for 100 hours in Air. (The darkened zone shows slag penetration into the crucible.)

Exhibit 2.2-96 shows an electron probe scan across the crucible sample shown in Exhibit 2.295, which includes the slag, the slag/surface interface, the underlying dark, slag-penetrated zone (about $3000 \mu \mathrm{m}$, or $3 \mathrm{~mm}$ ), and the white nonpenetrated zone (also about $3000 \mu \mathrm{m}$ in depth). Thus, the results of the exposure of the Monofrax M tiles and crucible to liquid Illinois \# 6 slag appear to be comparable for both testing conditions. 

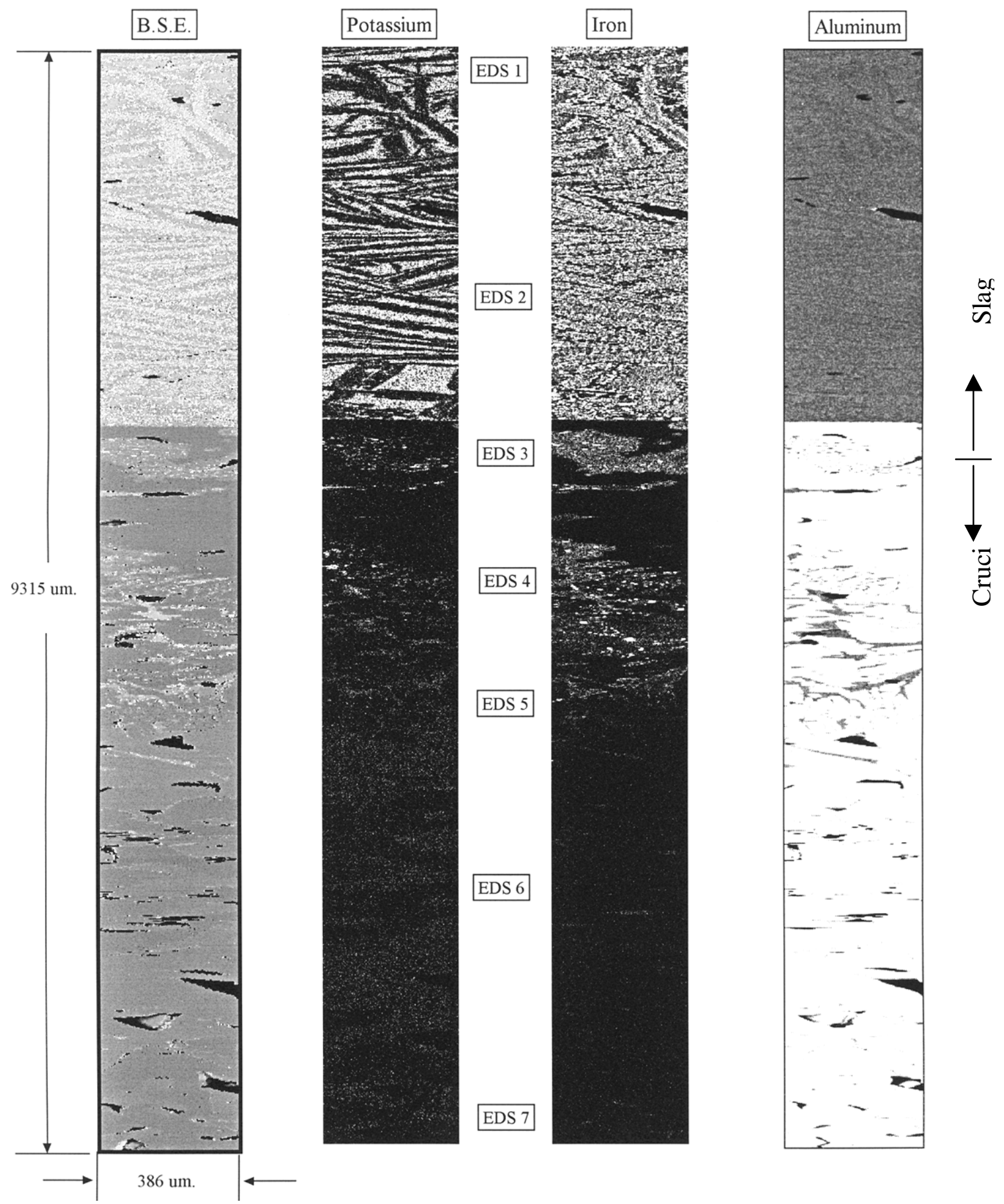

\section{Exhibit 2.2-96}

Electron Probe Photomicrographs of a Vertical Section through the Crucible in Exhibit 2.2-95

Note the sharp demarcation between slag and crucible. The slag (potassium, iron) has penetrated the fissures and voids in the crucible areas shown above. 


\section{Summary}

\section{Experimental Material.}

The ACF-10 experimental composition has gone through several tests (thermal conductivity, emissivity, and mechanical properties) and the results are all promising. The next step is to plan with Monofrax Inc., the casting of additional material so that it can be machined into a radiation tile for testing in the Pilot Test Facility at EERC.

$\underline{\text { Slag Test }} \underline{\text { Results. }}$

Under the conditions of exposing the Monofrax top panel of the large RAH to the Illinois \# 6 coal slag for approximately 140 hours and to a sub-bituminous coal slag for approximately 32 hours in the Pilot Test Facility, the Monofrax $\mathrm{M}\left(\alpha / \beta \mathrm{Al}_{2} \mathrm{O}_{3}\right)$ material held up quite well. The original surface that was exposed remained in tact, except for a few regions were the flowing slag wore a thin stream pattern down the vertical face of the tile. The penetration of the slag into the interior regions followed open voids and microcracks into the original material and was limited to a depth of 5-6 mm. Penetration was deeper in the larger surface cracks, but the overall reaction of the slag with the fused cast alumina particles was not severe. The same results were observed for a Monofrax M crucible that contained the molten Illinois \# 6 slag at $1450^{\circ} \mathrm{C}$ for 100 hours in air.

\section{Laboratory- and Bench-Scale Activities}

\section{Bench-Scale Activities}

Investigations continued this quarter into why the hard-face castable refractory used in the SFS underwent more shrinkage when fired than anticipated based on initial dilatometer tests. It was discovered in April that the Plicast 99 supplied for laboratory testing did not contain the organic fibers that were mixed into the refractory used in the SFS. During firing, these fibers burn out, leaving pores that permit the escape of water vapor.

Two dilatometer tests were run on a sample of Plicast 99 containing organic fibers to compare the permanent shrinkage with the original results for the material that did not contain fibers. The two tests showed that Plicast 99 that contained the organic fibers had a much higher permanent shrinkage than the sample that contained no fibers. Exhibit 2.2-97 shows a comparison of the plots of the two tests on material with fibers which showed shrinkages of $2.0 \%$ and $2.1 \%$ and the sample that did not contain fibers which had a permanent shrinkage of 0.7. 


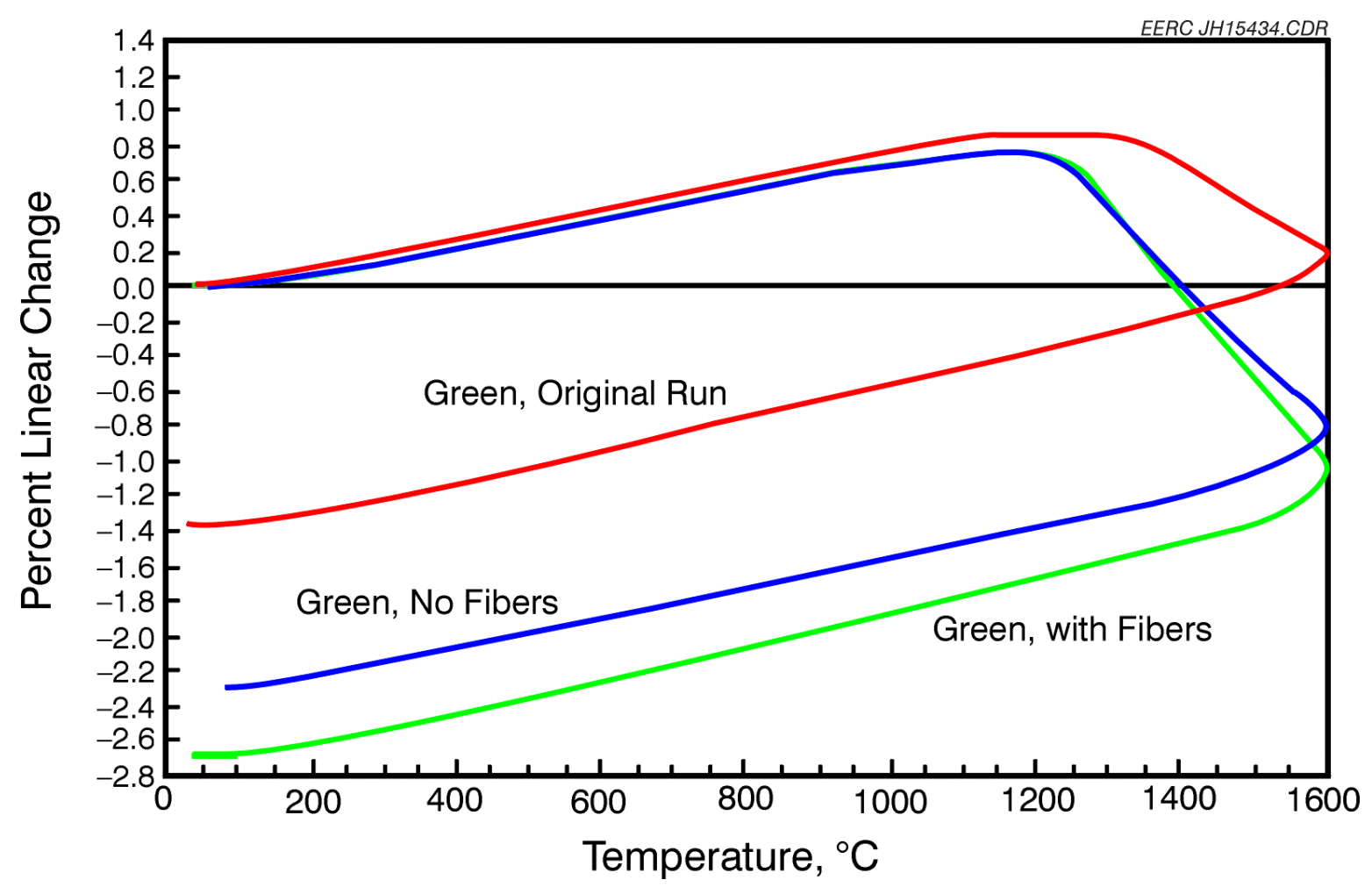

Exhibit 2.2-97

Graphs Indicating the Shrinkage of Plicast 99 versus Temperature for Two Samples Originally Containing Organic Fibers, and One Sample that did not Contain the Fibers

The greater shrinkage in the Plicast with the fibers is believed to be due to densification of the pores at high temperature. To check this assumption, the porosities of fired Plicast 99 containing fibers and Plicast 99 containing no fibers were compared using a scanning electron microscope (SEM). A sample of Plicast 99 containing fibers was fired to $2012^{\circ} \mathrm{F}\left(1100^{\circ} \mathrm{C}\right)$, which is just below the temperature at which shrinkage begins, and another sample was fired to $2732^{\circ} \mathrm{F}\left(1500^{\circ} \mathrm{C}\right)$. Exhibit $2.2-98$ shows the high porosity in the sample with fibers that was fired to $2012^{\circ} \mathrm{F}\left(1100^{\circ} \mathrm{C}\right)$ for 7 hours. Exhibit 2.2-99 shows the lower porosity in the sample containing fibers that was fired to $2732^{\circ} \mathrm{F}\left(1500^{\circ} \mathrm{C}\right)$. The sample fired to the higher temperature had about the same porosity as a sample with no fibers fired to the same temperature (Exhibit 2.2-100). The shape of the pores is better seen in the pictures of the samples which were embedded in epoxy and cross-sectioned shown in Exhibits 2.2-101 and 2.2-102. The porosity in the sample with fibers shown in Exhibit 2.2-101 was not as interconnected and irregularly shaped as the sample which contained no fibers shown in Exhibit 2.2-102. 


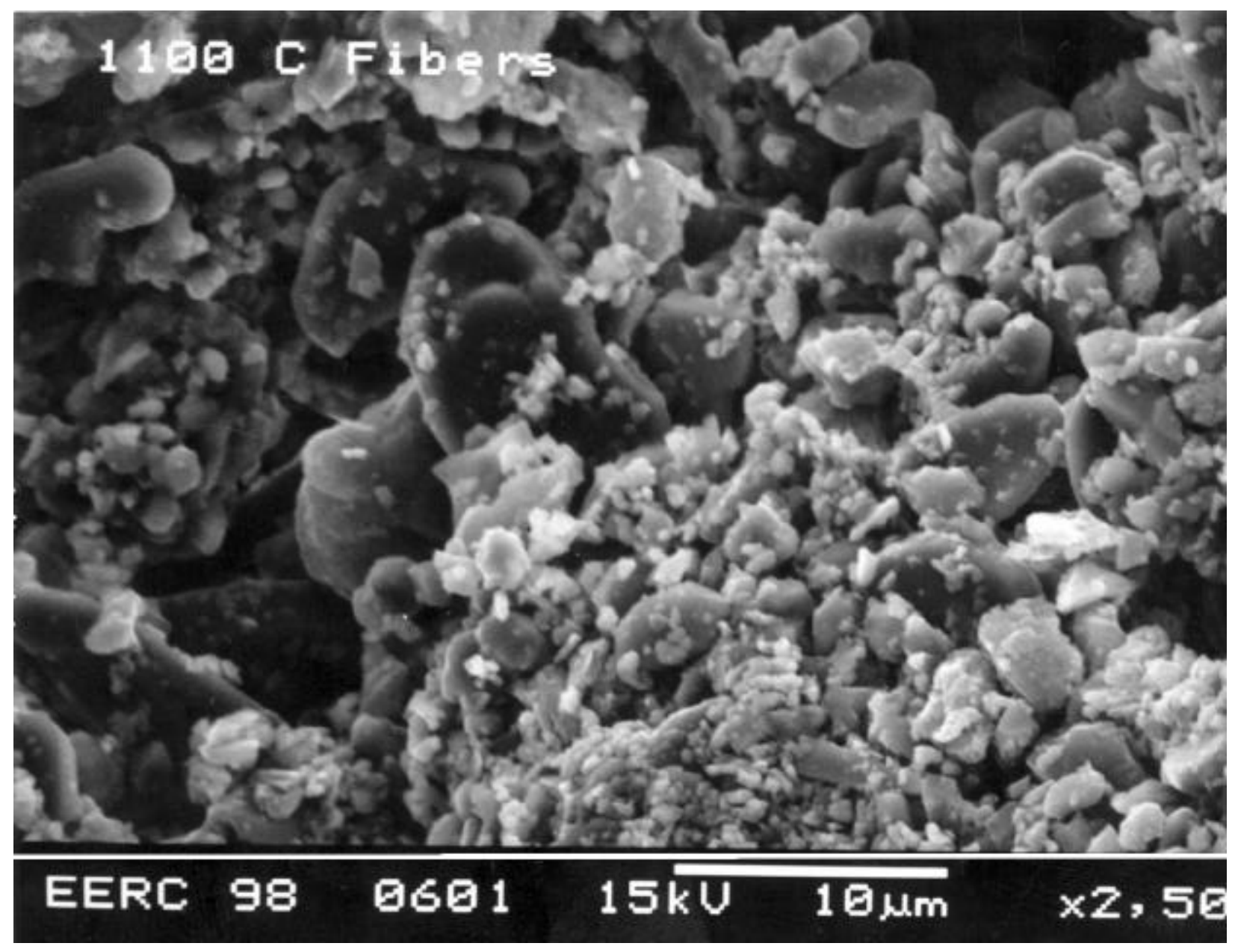

Exhibit 2.2-98

Scanning Electron Microscope Image Showing the Porosity of Plicast 99 Containing Organic Fibers and Fired at $2012{ }^{\circ} \mathrm{F}\left(1100^{\circ} \mathrm{C}\right)$ 


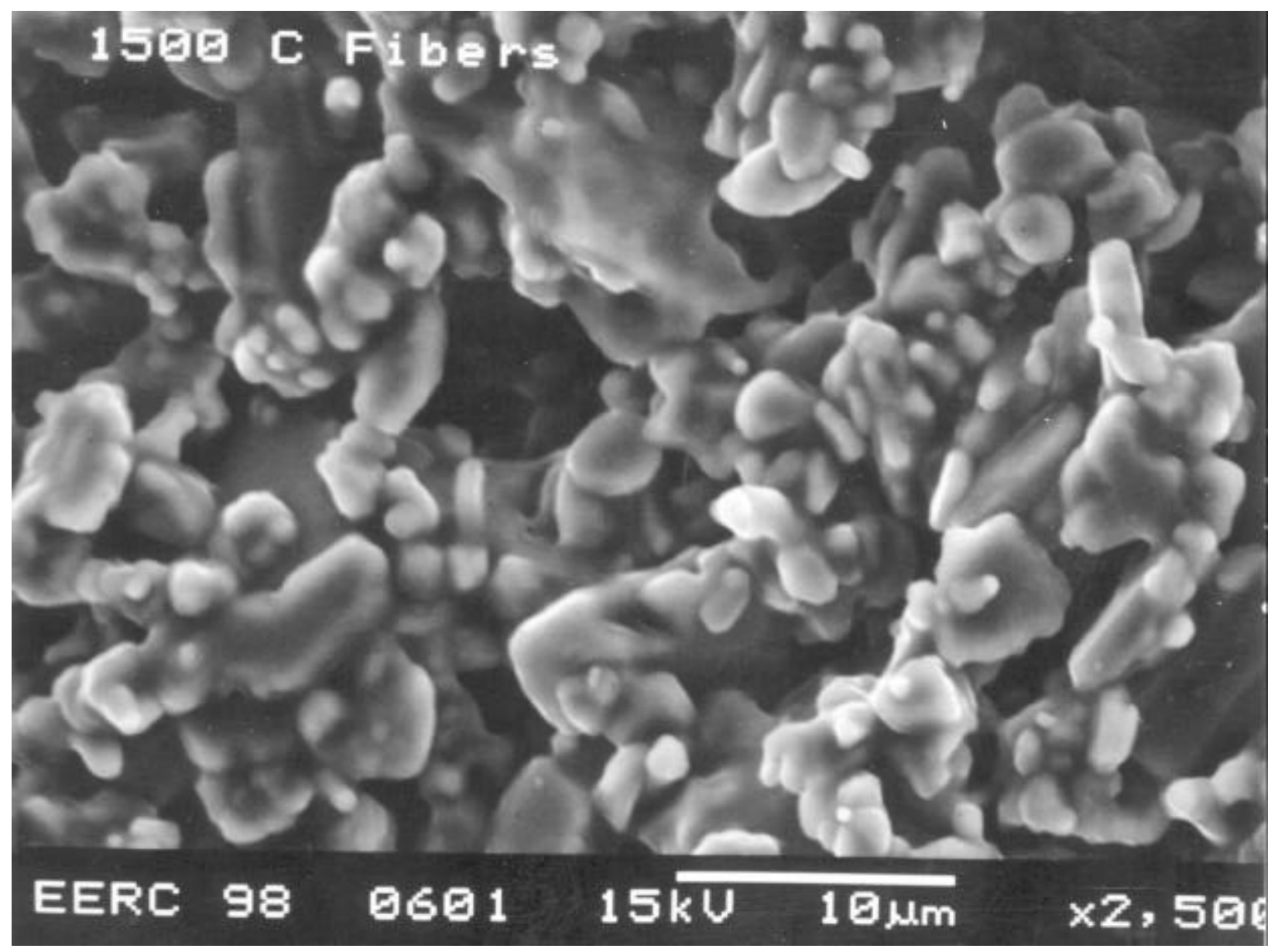

Exhibit 2.2-99

Scanning Electron Microscope Image Showing the Reduced Porosity of Plicast 99 Containing Organic Fibers and Fired at $2732^{\circ} \mathrm{F}\left(1500^{\circ} \mathrm{C}\right)$ 


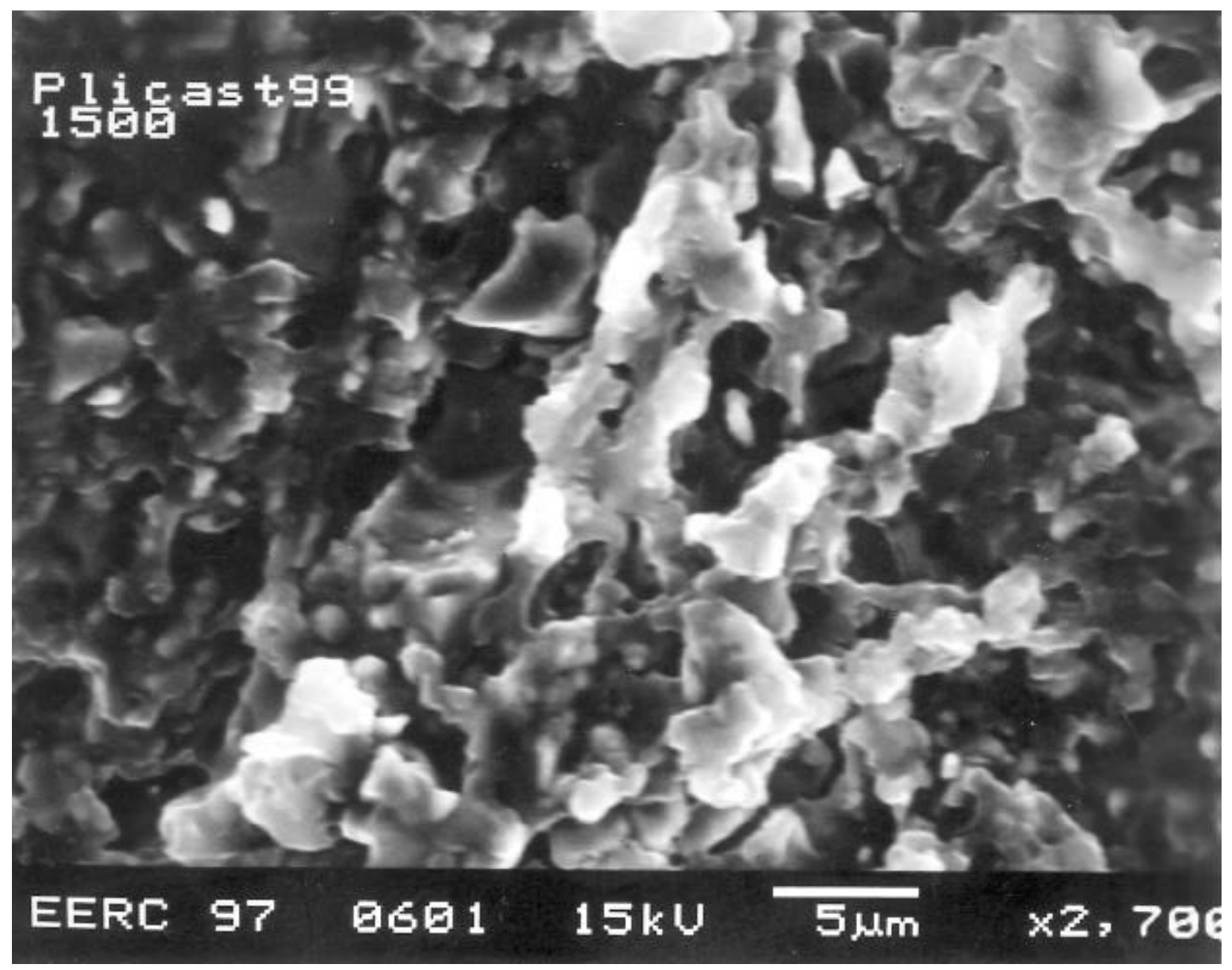

Exhibit 2.2-100

Scanning Electron Microscope Image Showing the Porosity in Plicast 99 not Containing Organic Fibers and Fired at $2732^{\circ} \mathrm{F}\left(1500^{\circ} \mathrm{C}\right)$ 


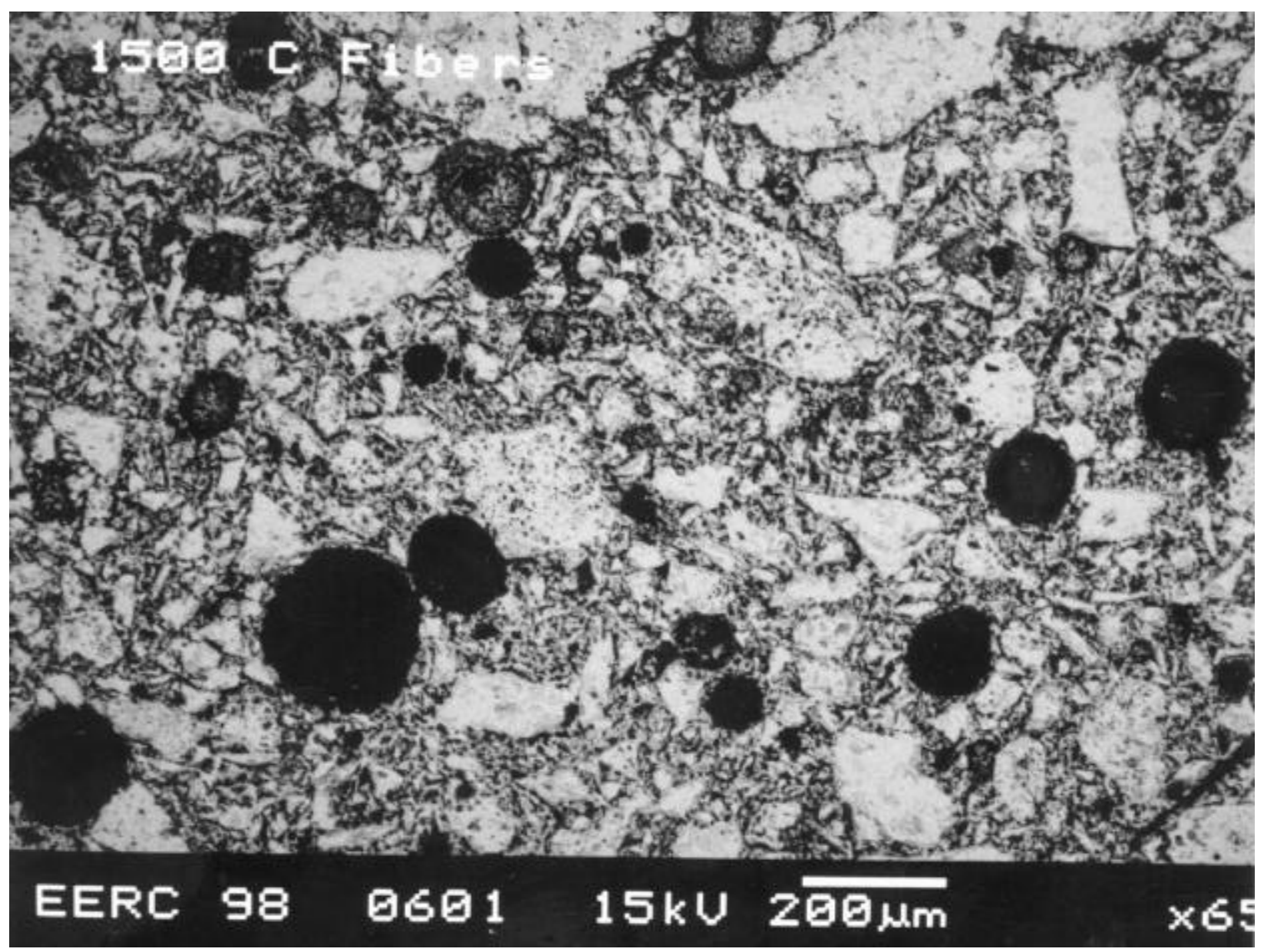

Exhibit 2.2-101

Scanning Electron Electron Microscope Image Showing the Shape of Pores in Plicast 99 Containing Organic Fibers and Fired at $2732{ }^{\circ} \mathrm{F}\left(1500^{\circ} \mathrm{C}\right)$ 


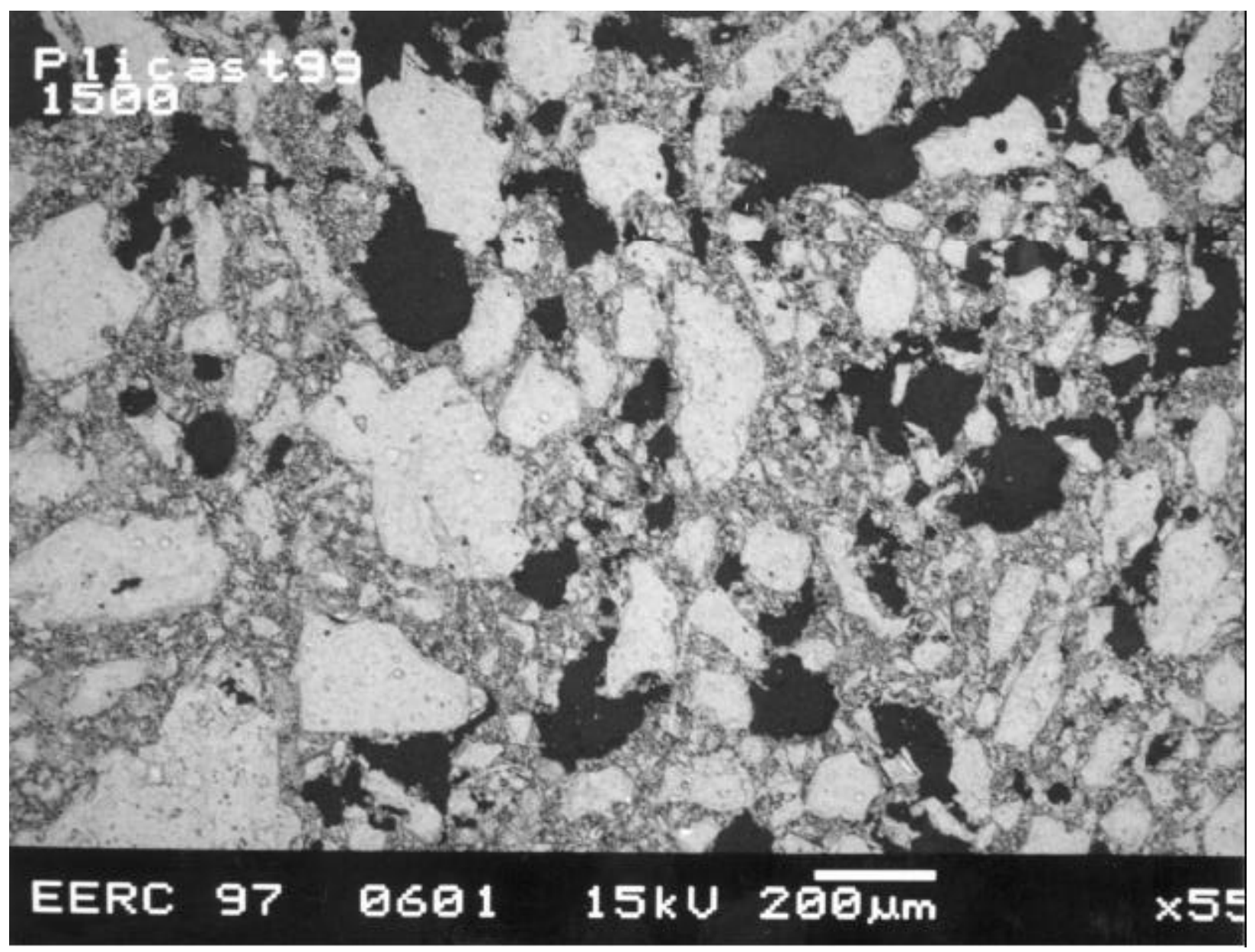

Exhibit 2.2-102

\section{Scanning Electron Microscope Image Showing the Shape of Pores in Plicast 99 not Containing Organic Fibers and Fired at $2732{ }^{\circ} \mathrm{F}\left(1500^{\circ} \mathrm{C}\right)$}

The data from the dilatometer tests, the porosity measurements, and the alumina transition data reported in the January through March quarterly, were reviewed. The conclusion resulting from this review is that the greatest factor affecting the permanent shrinkage is the sintering of the pores left after the burnout of the organic fibers and, to a lesser extent, the alumina phase transitions. Therefore, to reduce the amount of shrinkage observed in larger-scale applications of the Plicast 99, it will be necessary to reduce the amount of fibers in the raw material. However, this may require a slower heatup rate and longer dwell times at specific temperatures to allow the water vapor to escape.

Another example of how the firing temperature and time possibly affect the corrosion resistance was evident in the second 100-hr dynamic corrosion test using Illinois No. 6 slag at $2732^{\circ} \mathrm{F}\left(1500^{\circ} \mathrm{C}\right)$ on Plicast 99 . Exhibit $2.2-103$ shows that the recession rate of Plicast 99 at this temperature was at a considerably higher rate than that observed with the Monofrax M fusioncast alumina brick or with the original shorter test of the Plicast 99. Chemical analysis of the Plicast 99 raw material did not indicate a reason for the higher corrosion rate. However, EERC believes that instead of a change in composition of the Plicast causing an increase in corrosion 
rate, there may have been a change in the firing schedule of the new block as compared to the original shorter test. Since the records for the original test of the Plicast 99 were lost during the Flood of 1997, EERC cannot be sure of that firing temperature or schedule. EERC believes that the original block was fired at approximately $180^{\circ} \mathrm{F}\left(100^{\circ} \mathrm{C}\right)$ higher than the block used in the later 100 -hr test. We know that the second test was fired at $2732^{\circ} \mathrm{F}\left(1500^{\circ} \mathrm{C}\right)$ over a period of 24 hours, held for 2 hours, then slag was fed. This may not be adequate time for complete sintering to occur and indicates why the new patches of refractory used in the SFS were so prone to corrosion during the lignite tests.

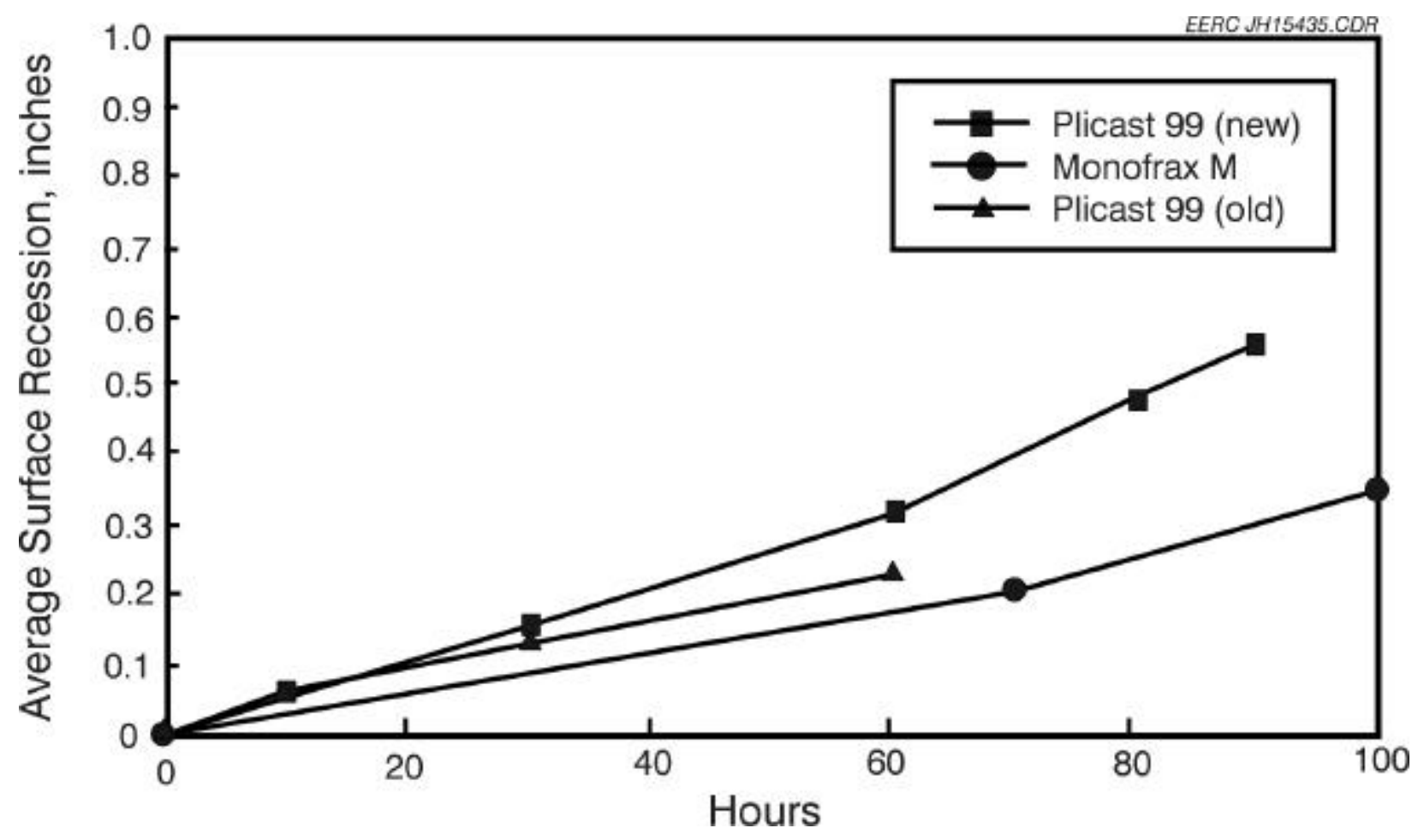

Exhibit 2.2-103

\section{Graph Showing the Corrosion Rates of the Original Plicast 99 Block, Monofrax M, and a new Plicast 99 Block with Illinois No. 6 Slag at $2732{ }^{\circ} \mathrm{F}\left(1500^{\circ} \mathrm{C}\right)$}

In addition to more fully sintering the refractory to reduce corrosion rates, it may be possible to reduce the corrosiveness of the slag itself through the use of coal additives. To test this hypothesis, we ran a 100 -hour dynamic corrosion test on Plicast 99 fired to $2732^{\circ} \mathrm{F}\left(1500^{\circ} \mathrm{C}\right)$ using Illinois No. 6 slag that was modified with the addition of $5 \mathrm{wt} \%$ alumina. The addition of alumina in the Illinois No. 6 slag causes the viscosity of the slag to increase, slowing the mass transport of the corrodents to the refractory surface, and may also partially saturate the slag with alumina. Exhibit 2.2-104 shows the change in the alumina content of the slag leaving the DSAF for both the initial test without alumina added and the test with alumina added to the slag. The increase in alumina content in the baseline slag leaving the DSAF is believed to be due to the inclusion of alumina aggregate in the slag leaving the furnace as the cementitious alumina is dissolved from the block face. In contrast, the slag leaving the DSAF that contained the 5\% added alumina was lower in alumina than expected because of losses in the feed tube. 


\section{Exhibit 2.2-104}

Composition of Slags Over Time as Determined by X-Ray Fluorescence

\begin{tabular}{|c|c|c|c|c|c|c|c|c|}
\hline $\begin{array}{c}\text { Oxide, } \\
\text { wt } \%\end{array}$ & $\begin{array}{l}\text { Ill. No. } 6 \\
\text { Slag } \\
\text { Initial } \\
\text { Comp. }\end{array}$ & $\begin{array}{c}\text { After } 2 \mathrm{hr} \\
\text { of Slag } \\
\text { Feed }\end{array}$ & $\begin{array}{c}\text { After } 47.5 \\
\text { hr of Slag } \\
\text { Feed }\end{array}$ & $\begin{array}{c}\text { After } 90 \\
\text { hr of Slag } \\
\text { Feed }\end{array}$ & $\begin{array}{c}\text { Ill. No. } 6 \\
+5 \% \\
\mathrm{Al}_{2} \mathrm{O}_{3} \\
\text { Initial } \\
\text { Comp. }\end{array}$ & $\begin{array}{c}\text { After } 3 \mathrm{hr} \\
\text { of Slag } \\
\text { Feed }\end{array}$ & $\begin{array}{c}\text { After } 50 \\
\text { hr of Slag } \\
\text { Feed }\end{array}$ & $\begin{array}{r}\text { After } \\
100 \mathrm{hr} \text { of } \\
\text { Slag Feed }\end{array}$ \\
\hline $\mathrm{SiO}_{2}$ & 54.4 & 50.1 & 49.7 & 50.7 & 47.3 & 49.8 & 50.0 & 49.4 \\
\hline $\mathrm{Al}_{2} \mathrm{O}_{3}$ & 19.0 & 21.9 & 24.2 & 23.5 & 26.0 & 23.2 & 24.0 & 24.8 \\
\hline $\mathrm{Fe}_{2} \mathrm{O}_{3}$ & 15.6 & 16.4 & 14.6 & 14.5 & 14.8 & 15.0 & 14.6 & 14.5 \\
\hline $\mathrm{TiO}_{2}$ & 0.7 & 0.7 & 0.8 & 0.8 & 0.8 & 0.8 & 0.8 & 0.8 \\
\hline $\mathrm{P}_{2} \mathrm{O}_{5}$ & 0.0 & 0.0 & 0.2 & 0.2 & 0.2 & 0.2 & 0.2 & 0.2 \\
\hline $\mathrm{CaO}$ & 7.1 & 7.2 & 6.3 & 6.3 & 6.4 & 6.5 & 6.4 & 6.3 \\
\hline $\mathrm{MgO}$ & 1.3 & 1.5 & 1.5 & 1.4 & 1.5 & 1.5 & 1.5 & 1.5 \\
\hline $\mathrm{Na}_{2} \mathrm{O}$ & 0.0 & 0.2 & 0.9 & 0.8 & 1.0 & 1.0 & 0.7 & 0.7 \\
\hline $\mathrm{K}_{2} \mathrm{O}$ & 1.8 & 1.9 & 1.8 & 1.7 & 1.8 & 1.8 & 1.8 & 1.7 \\
\hline $\mathrm{SO}_{3}$ & 0.0 & 0.0 & 0.1 & 0.1 & 0.1 & 0.1 & 0.1 & 0.1 \\
\hline
\end{tabular}

The actual changes in the average surface recession with time caused by the addition of the alumina to the Illinois No. 6 slag are illustrated in Exhibit 2.2-105. The data show that the alumina addition to the slag decreased the recession after 100 hours by over $60 \%$. Additions of greater amounts of alumina to the slag should decrease corrosion rates even further. Also, the cost of adding the alumina to the coal should be relatively low. For example, much less additive is needed to increase the alumina concentration in the slag by $10 \%$ than the weight of sulfur sorbent that must be used in a pressurized fluidized-bed combustor when firing a high-sulfur coal. 


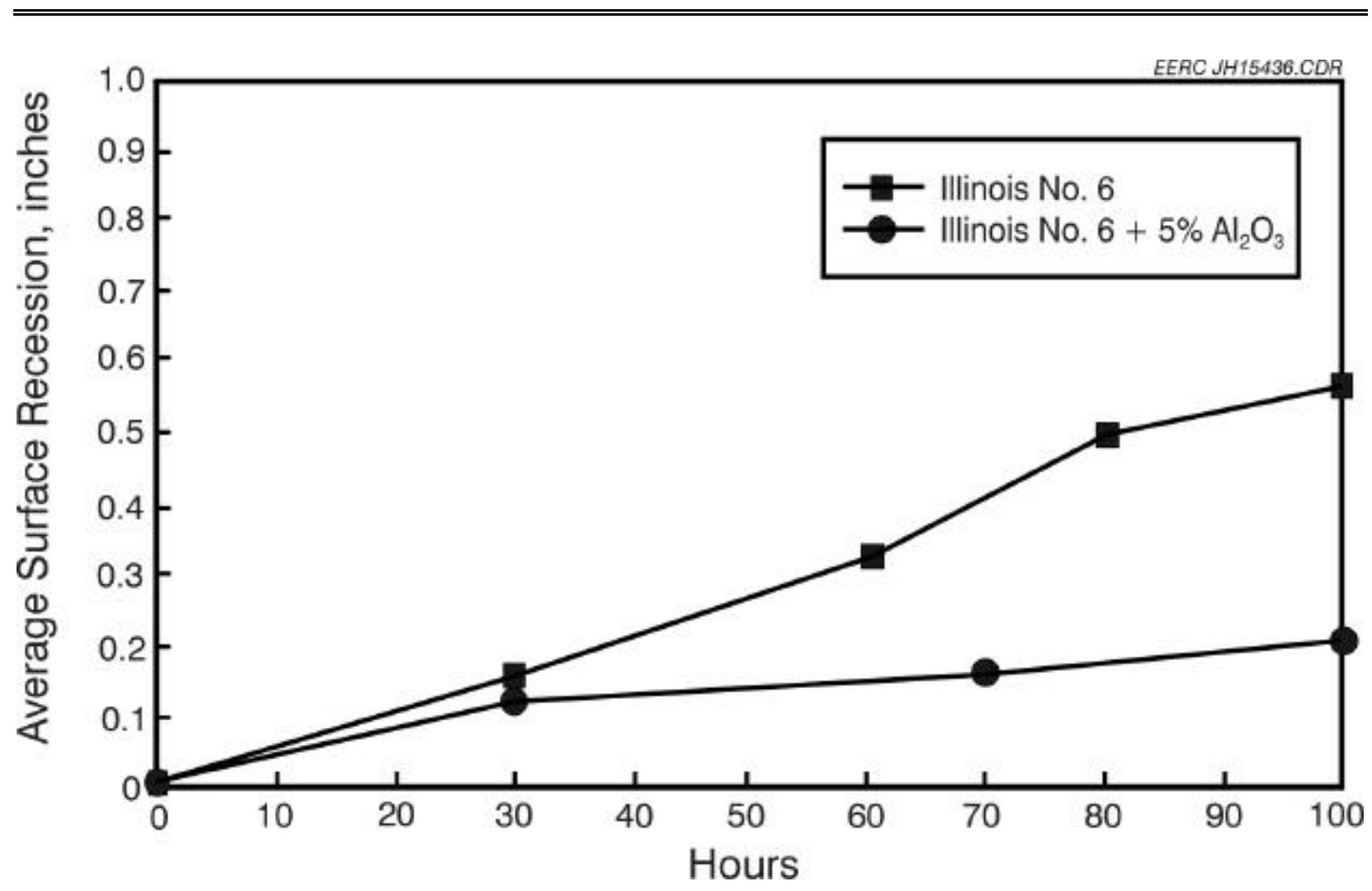

Exhibit 2.2-105

\section{Graph Showing the Corrosion Rates of the plicast 99 Block with Illinois no. 6 Slag and Illinois No. 6 Slag with $5 \%$ Alumina Addition at $2732{ }^{\circ} \mathrm{F}\left(1500^{\circ} \mathrm{C}\right)$}

The deposition of the alumina in the feed tube caused the tube to plug every several hours. Therefore a new method of feeding is needed before further tests using alumina additions will be run. The current method involves mixing the slag and alumina in batches of approximately $2.2 \mathrm{lb}$ $(1 \mathrm{~kg})$. A total of $50 \mathrm{lb}$ would be needed for a 100-hr dynamic corrosion test of four bricks at the current feed rate of $51 \mathrm{~g} / \mathrm{hr}$ per injector. The +16 - to +20 -mesh slag was mixed dry with +325 mesh hydrateable alumina for 2 minutes using a Hobart mixer. Water was added ( $6.7 \%$ by weight) and mixed for 5 minutes, until all the slag particles appeared to be coated with alumina. The slag-alumina mix was then air-dried at room temperature $\left(21^{\circ}-25^{\circ} \mathrm{C}\right)$ overnight. Before pouring into the feeder, the dried mixture was broken up with a large spoon. As the slag moved through the feed tube by the augers, some of the fine alumina particles separated from the slag and stuck to the hot ceramic tubes at the entrance to the furnace. It would probably work better to fuse or at least sinter the mixture, then crush and size it before it is fed.

EERC is currently testing the corrosion rate of the Plicast 99 with Coal Creek lignite slag collected from the SFS slag pot after the first lignite test. To test the hypothesis that the firing temperature and length of time at that temperature affect the corrosion resistance of the Plicast 99, EERC is performing a 100-hr corrosion test with two Plicast blocks. One block was fired to $2910^{\circ} \mathrm{F}\left(1600^{\circ} \mathrm{C}\right)$ over a period of 24 hours, the temperature was held for 24 hours, then slowly ramped down to room temperature. The second block was fired by the usual method at $2732^{\circ} \mathrm{F}$ $\left(1500^{\circ} \mathrm{C}\right)$ over a $24-\mathrm{hr}$ period, held for two hours, then the slag feed was started. To date, a total of 30 hours of slag feed has been completed; the average surface recession measured after 18 
hours of slag feed shows that the sample fired to $2910^{\circ} \mathrm{F}\left(1600^{\circ} \mathrm{C}\right)$ was approximately $30 \%$ less than the sample fired to $2732^{\circ} \mathrm{F}\left(1500^{\circ} \mathrm{C}\right)$. This test will be completed in July. 


\section{Task 6 HIPPS Commercial Plant Design Update}

The analyses of repowering with an all coal configuration continued into this reporting period. Four scenarios were considered: FT8 with combustor exit temperatures (radiator exit temperatures) of $1800 \mathrm{~F}$ and $2100 \mathrm{~F}$ and FT $4000 \mathrm{SC}$ with the same temperatures. For these analyses, the DoE-furnished steam station in up-state NY is being used. This plant was approximately $122 \mathrm{MW}$ at $1450 \mathrm{psi}$ and $1000 \mathrm{~F} / 1000 \mathrm{~F}$ with an efficiency of $35 \%$.

Preliminary results are available only for repowering with the FT8. The results indicate that the efficiencies of the repowered plants would vary from about $40 \%$ for a four engine system at $1800 \mathrm{~F}$ to about $43 \%$ for a similar system at $2100 \mathrm{~F}$. Exhibit 6-1 shows a schematic of the FT8based system and Exhibit 6-2 outlines the system performance. These results are derived through retrofitting the existing steam turbine with a larger back end to accommodate the additional flow resulting from shutting down the extraction feed water heaters. This heat is now supplied by the GT exhaust.

A preliminary investigations to identify advanced HIPPS configuration with efficiencies approaching 60\% (LHV) was initiated. These plants would have performances levels equivalent to the plants being identified in the DoE/FETC Advanced Turbine System Program, but would be based on coal; i.e., coal would furnish at least $50 \%$ of the power cycle heat. This preliminary effort has identified a Cascaded Humidified Advanced Turbine (CHAT) cycle with an efficiency over 55\% (HHV) or nearly 60\% LHV. Also, a HIPPS/HAT cycle has been identified with an efficiency of approximately 55\% (HHV) or about 59\% LHV. The details of these plants are shown in Exhibit 6-3 along with the initial FT4000 IC configuration and the FT4000 IC version used in the DoE-sponsored Advanced Turbine Systems Phase 1. A preliminary CHAT/ HIPPS configuration is shown in Exhibit 6-4. 


\begin{tabular}{|c|c|c|c|}
\hline \multicolumn{4}{|c|}{$\begin{array}{c}\text { Exhibit 6-1 } \\
\text { FT8 Gas \& All-Coal (HITAF) Repowering Performance }\end{array}$} \\
\hline & PW & HITAF & HITAF \\
\hline & FT8 & $1800 \mathrm{~F}$ & $2100 \mathrm{~F}$ \\
\hline Number of GT engines & 1 & 4 & 4 \\
\hline Type of fuel & Nat Gas & Coal & Coal \\
\hline \multicolumn{4}{|l|}{ System Performance } \\
\hline Total net power, MW & 25.6 & 191.2 & 202.8 \\
\hline Gross Gas Turbine power, MW & 25.6 & 64.3 & 82.8 \\
\hline Gross Steam Turbine power, MW & 0 & 136.0 & 128.9 \\
\hline Cycle Efficiency, net (LHV gas) & $38.7 \%$ & $40.4 \%$ & $42.8 \%$ \\
\hline Cycle Efficiency, gross (HHV coal) & NA & $42.3 \%$ & $44.7 \%$ \\
\hline \multicolumn{4}{|l|}{ Gas Turbine Performance } \\
\hline GT HPT temp, F & ----- & 1800 & 2100 \\
\hline GT LPT temp, F & ----- & 1308 & 1515 \\
\hline GT power turbine temp, $\mathrm{F}$ & ----- & 995 & 1195 \\
\hline GT exhaust temp, F & 856 & 667 & 775 \\
\hline GT stack temp, F & 856 & 180 & 180 \\
\hline Turbine Cooling (\% Inlet) & ----- & 10.5 & 17.7 \\
\hline Fuel flow rate, $\mathrm{lbs} / \mathrm{sec}$ & 3.028 & NA & NA \\
\hline \multicolumn{4}{|l|}{ HITAFF Combustor } \\
\hline Coal flow rate, $\mathrm{lbs} / \mathrm{sec}$ & NA & 35.52 & 35.52 \\
\hline Radiant sect., GT Outlet temp, F & NA & 1800 & 2100 \\
\hline Convective HX outlet temp, F & NA & 1300 & 1300 \\
\hline HITAF HRSG stack temp, F & NA & 300 & 300 \\
\hline \multicolumn{4}{|l|}{$\underline{\text { Repowered Steam System }}$} \\
\hline Throttle flow, lbs/sec & NA & 209.9 & 199.1 \\
\hline Pressure, psia & NA & 1477 & 1477 \\
\hline Temperature, F & NA & 956 & 956 \\
\hline \multicolumn{4}{|l|}{ Steam Turbine flow parameter $(*)$} \\
\hline$\left(\mathrm{W}^{*} \mathrm{~T}\right) / \mathrm{P}$ & NA & 5.35 & 5.07 \\
\hline Reheat turbine flow, lbs/sec & NA & 209.9 & 199.1 \\
\hline Pressure, psia & NA & 454 & 454 \\
\hline Temperature, F & NA & 1008 & 1008 \\
\hline
\end{tabular}

(*) Base, DOE steam station, $\mathrm{FP}=5.48$ 


\begin{tabular}{|c|c|c|c|c|}
\hline \multirow[b]{3}{*}{ Type of fuel } & \multicolumn{3}{|c|}{$\begin{array}{l}\text { Exhibit 6-2 } \\
\text { Coal (HITAF) Performance } \\
\text { (1 Engine) }\end{array}$} & \multirow{3}{*}{$\begin{array}{c}\text { CHAT } \\
\text { Gas/Coal }\end{array}$} \\
\hline & PW & METC & AHIPS & \\
\hline & Nat Gas & Gas & Gas/Coal & \\
\hline \multicolumn{5}{|l|}{ System Performance } \\
\hline Total net power, MW & 144.0 & 329.8 & 346.9 & 316.0 \\
\hline Gross Gas Turbine power, MW & 146.9 & 333.1 & 352.8 & 290.0 \\
\hline Cycle Efficiency, net (HHV) & & 54.7 & 53.4 & 54.9 \\
\hline Cycle Efficiency, Gross (HHV) & & 55.2 & 55.1 & 55.5 \\
\hline Cycle Efficiency, gross (LHV) & 45.8 & 61.3 & 59.1 & 59.6 \\
\hline Gas/Coal Ratio & 1.0 & 1.0 & .470 & .50 \\
\hline \multicolumn{5}{|l|}{ Gas Turbine Performance } \\
\hline GT HPT temp, F & ----- & 3100 & 2900 & 3060 \\
\hline GT LPT temp, F & ----- & 2365 & 2405 & 2555 \\
\hline GT Reheat in, F & & & & 2354 \\
\hline GT power turbine temp, $\mathrm{F}$ & ----- & & 2200 & 2450 \\
\hline GT exhaust temp, F & 721 & 952 & 1002 & 1193 \\
\hline GT stack temp, F & 721 & 240 & 177 & 120 \\
\hline Turbine Cooling (\% Inlet) & ----- & 31.5 & 23.5 & 18.9 \\
\hline Gas Fuel flow rate, lbs/sec & 14.4 & 24.7 & 12.1 & 11.8 \\
\hline Saturator flow rate, $\mathrm{lbs} / \mathrm{sec}$ & 0.0 & 152.9 & 189.5 & 131.1 \\
\hline Saturator outlet temp, F & NA & 394 & 370 & 410 \\
\hline \multicolumn{5}{|l|}{$\underline{\text { HITAFF Combustor }}$} \\
\hline Coal flow rate, $\mathrm{lbs} / \mathrm{sec}$ & NA & NA & 25.9 & 24.6 \\
\hline Convective HX outlet temp, F & NA & NA & 1300 & 1464 \\
\hline Radiant HX outlet temp, F & NA & NA & 2100 & 2100 \\
\hline
\end{tabular}




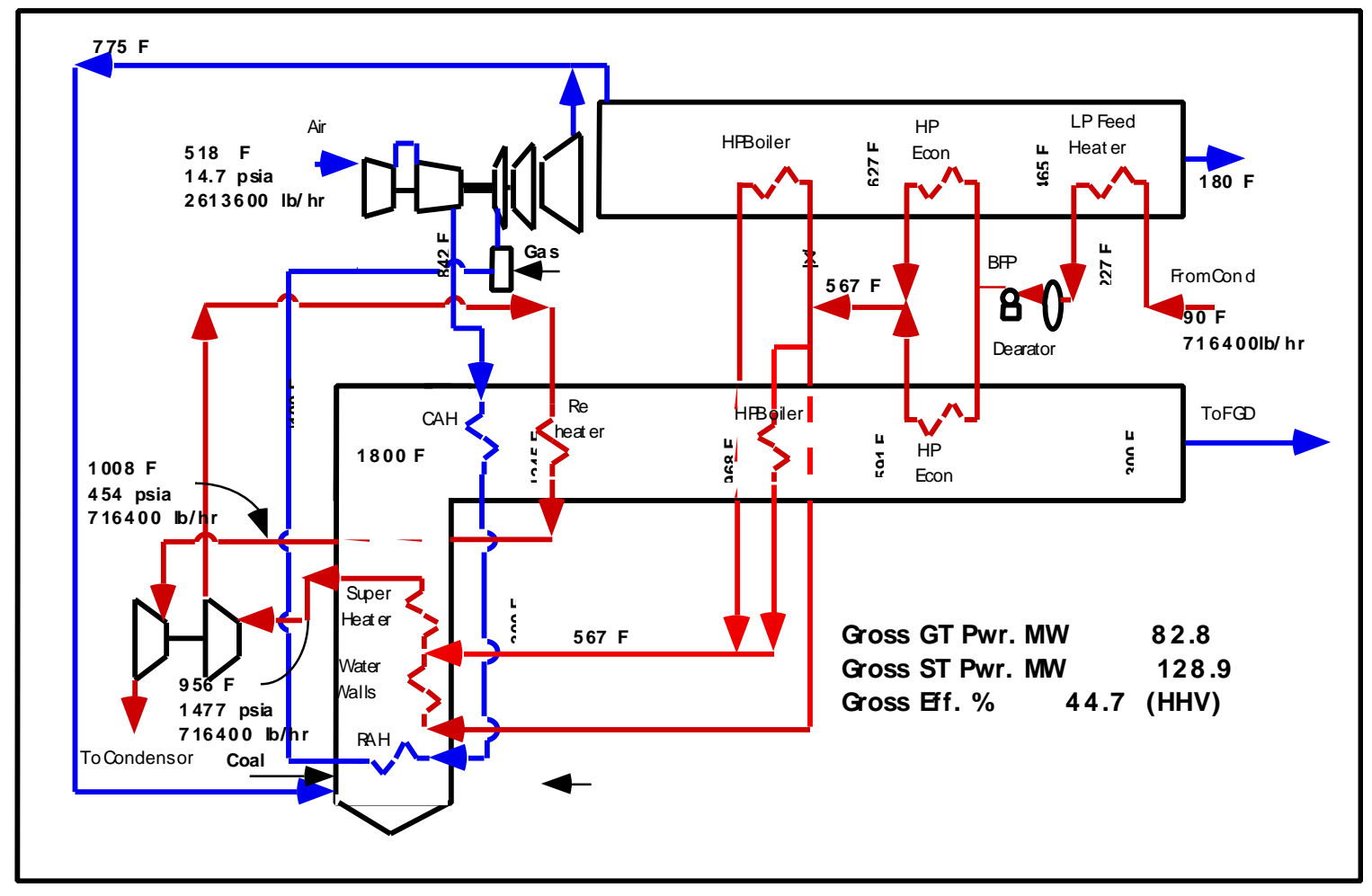

Exhibit 6-3

Preliminary Schematic of All Coal Repowering with the FT8 


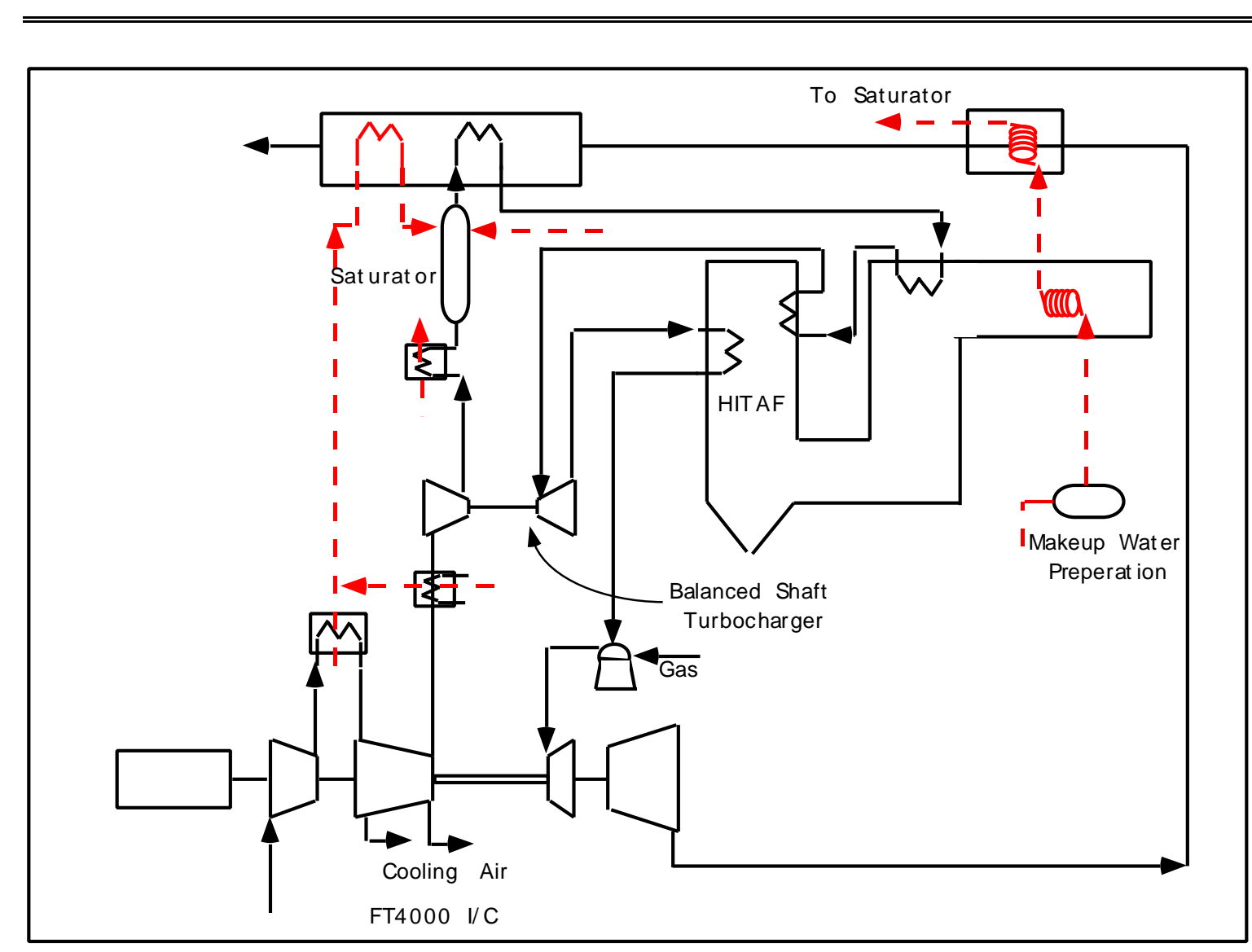

Exhibit 6-4

HIPPS/CHAT Cycle Configuration 